\title{
Provenance of the Hamilton Group: A Study of Source-to-Sink Relationships within the Middle Devonian Central Appalachian
} Basin

Brittany N. Hupp

Follow this and additional works at: https://researchrepository.wvu.edu/etd

\section{Recommended Citation}

Hupp, Brittany N., "Provenance of the Hamilton Group: A Study of Source-to-Sink Relationships within the Middle Devonian Central Appalachian Basin" (2017). Graduate Theses, Dissertations, and Problem Reports. 5846.

https://researchrepository.wvu.edu/etd/5846

This Thesis is protected by copyright and/or related rights. It has been brought to you by the The Research Repository @ WVU with permission from the rights-holder(s). You are free to use this Thesis in any way that is permitted by the copyright and related rights legislation that applies to your use. For other uses you must obtain permission from the rights-holder(s) directly, unless additional rights are indicated by a Creative Commons license in the record and/ or on the work itself. This Thesis has been accepted for inclusion in WVU Graduate Theses, Dissertations, and Problem Reports collection by an authorized administrator of The Research Repository @ WVU. For more information, please contact researchrepository@mail.wvu.edu. 


\title{
Provenance of the Hamilton Group: A study of source-to-sink relationships within the Middle Devonian central Appalachian Basin
}

\author{
Brittany N. Hupp \\ Thesis submitted \\ to the Eberly College of Arts and Sciences \\ at West Virginia University \\ in partial fulfillment of the requirements for the degree of \\ Master of Science in \\ Geology
}

\author{
Amy Weislogel, Ph.D., Chair \\ Joe Donovan, Ph.D. \\ Shikha Sharma, Ph.D.
}

Department of Geology and Geography

Morgantown, West Virginia
2017

Keywords: Marcellus Shale, Mahantango Formation, Hamilton Group, mudrock, provenance

Copyright 2017 Brittany N. Hupp 


\section{ABSTRACT \\ Provenance of the Hamilton Group: A study of source-to-sink relationships within the Middle Devonian central Appalachian Basin}

\section{Brittany N. Hupp}

Little is known of the provenance of detrital clays in the Hamilton Group, which contains one of the most lucrative unconventional shale gas plays in the world. The Hamilton Group consists of both the organic-rich Marcellus Shale and the overlying, clay-rich Mahantango Formation. This research, in collaboration with the Marcellus Shale Energy and Environmental Laboratory (MSEEL) project, aims to constrain the provenance of the two units within the Hamilton Group and evaluate paleoclimate indicators in order to better understand the role of clastic influx on organic-matter production and preservation within the Middle Devonian Acadian foreland basin.

Geochemical and petrographic analysis of 121 samples from two different wells in Monongalia Co., West Virginia indicate slight changes in provenance throughout the deposition of the Marcellus Shale into the Mahantango Formation. Major and trace element geochemistry indicates a felsic igneous, upper-continental crust sediment source of granodioritic composition with additional influx from a quartzose recycled sedimentary source. Nine samples throughout the Hamilton Group underwent Sm-Nd isotopic analysis, yielding $\varepsilon_{\mathrm{Nd}}$ values ranging from -7.06 to -11.75 and $\mathrm{Nd}$ depleted mantle model ages $\left(\tau_{\mathrm{Nd}}\right)$ ranging from $1.63-1.85 \mathrm{Ga}$, with ages becoming younger upsection. Mineralogical data acquired from x-ray diffraction analysis found the dominant mineral phases to be illite, muscovite, and quartz with fairly consistent mineralogy found throughout the Mahantango Formation and slightly more heterogeneous mineralogy found throughout the Marcellus Shale. Weathering indices including the CIA, CIW, and ICV all indicate increased weathering throughout the deposition of the Marcellus Shale followed by constant moderate rates of weathering during deposition of the Mahantango Formation.

These results suggest that the extrabasinal detrital sediments of the Hamilton Group came from a mixed sediment source with clay influx from both the Superior Craton to the north $\left(\tau_{\mathrm{Nd}}>2.7 \mathrm{Ga}\right)$ and Grenville-sourced sediments of the adjacent Acadian fold-thrust belt to the east $(\sim 1.0-1.3 \mathrm{Ga})$. Older model ages, felsic composition, and evidence of sediment recycling suggest little to no influx from the Acadian volcanic arc, aside from the volcanic air fall tuffs of the Tioga Ashes. Model ages and trace element geochemistry indicate increased sediment influx from the fold-thrust belt during the deposition of the Hamilton Group, with the highest sediment influx having occurred during Mahantango Formation deposition. Petrographic and geochemical analyses suggest that variations in organic-content throughout the Hamilton Group is due to dilution of organic-matter by increased influx of detrital clays during its deposition, particularly within the Mahantango Formation. Consistent clay mineralogy and weathering indices suggest that this influx of detrital sediment is not a function of climate fluctuations at this time, but rather may be influenced by increased tectonic activity and fluvial progradation during the second tectophase of the Acadian Orogeny. 


\section{TABLE OF CONTENTS}

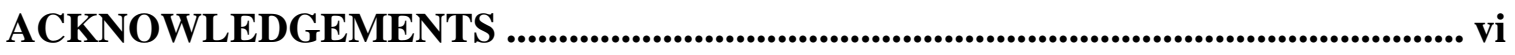

LIST OF FIGURES ................................................................................................ viii

LIST OF TABLES AND EQUATIONS .............................................................................. xi

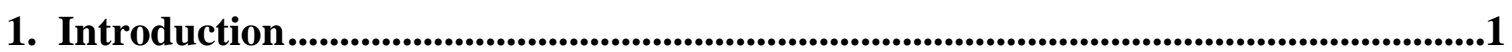

1.1 Research Purpose .....................................................................................................1

1.1.1 Marcellus Shale Energy and Environmental Laboratory (MSEEL) ........1

1.1.2 Research Objectives...............................................................................................1

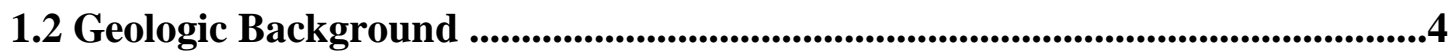

1.2.1 Tectonic Setting ..........................................................................................4

1.2.2 Stratigraphy of the Acadian Basin ...............................................................4

1.2.3 Devonian Paleoclimate...............................................................................13

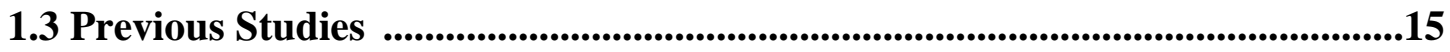

1.3.1 Provenance Terrane surrounding the Middle Devonian Acadian

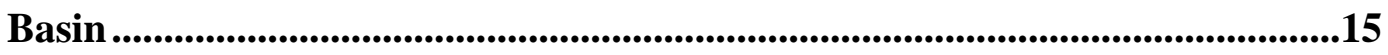

1.3.2 Previous provenance analysis of Acadian syn-orogenic sediments ........21

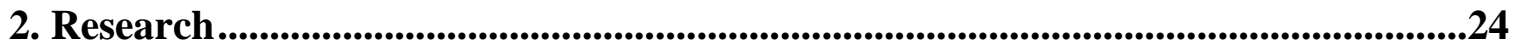

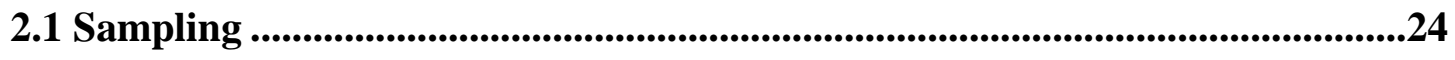

2.1.1 MSEEL: MIP-3H ....................................................................................................24

2.1.2 WV-6 .....................................................................................................24

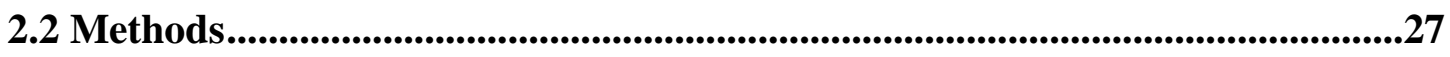

2.2.1 Thin-section Petrography ................................................................................27

2.2.2 X-ray Diffraction Geochemical Analysis (XRD) .........................................28

2.2.3 X-ray Fluorescence Geochemical Analysis (XRF) ................................29

2.2.4 Samarium-Neodymium (Sm-Nd) Isotopic Analysis..................................34

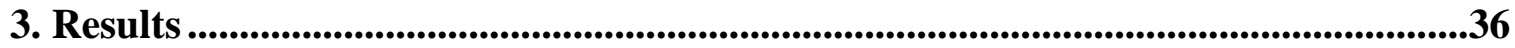

3.1 Petrographic Results.....................................................................................................36

3.1.1 Petrofacies 1: Tarly Claystone.............................................................36

3.1.2 Petrofacies 2: Organic-rich Argillaceous Sarl..........................................42

3.1.3 Petrofacies 3: Styliolinid Carl ........................................................................44 
3.1.4 Petrofacies 4: Silty Tarly Claystone .46

3.2 Geochemical Results ..................................................................................48

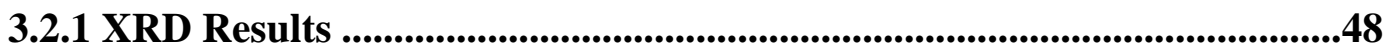

3.2.2 XRF Results ......................................................................................57

3.2.3 Sm-Nd Isotopic Dating Results ..................................................................71

4. Discussion.

4.1 Constraints on sediment influx from Hamilton Group petrography and mineralogy .074

4.2 Source rock lithology from geochemical composition .....................................79

4.3 Source area age characterization .............................................................81

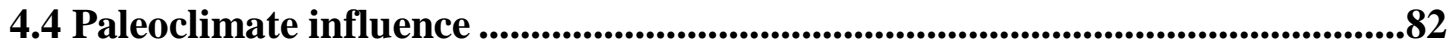

4.5 Provenance model and evolution ..............................................................................883

4.6 Provenance, paleoclimate, and controls on organic-matter preservation .......90

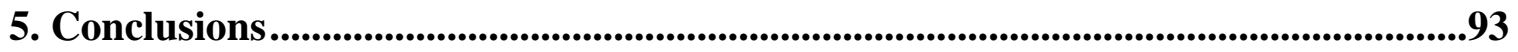

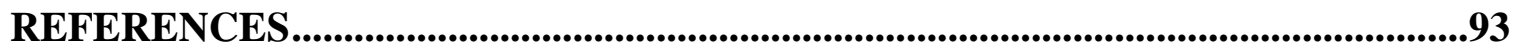

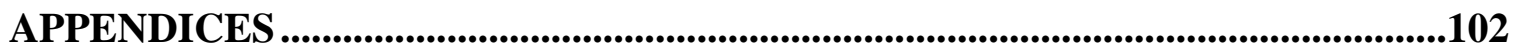

Appendix I. X'Pert HighScore Plus Mineral Identification Information..............102

Appendix II. RIR XRD mineralogical data from the MIP-3H well ....................103

Appendix III. XRF-quantified XRD mineralogical data from the MIP-3H well.104

Appendix IV. RIR XRD mineralogical data from the WV-6 well..........................106

Appendix V. XRF-quantified XRD mineralogical data from the WV-6 well ......108

Appendix VI. Image of samples prepared for XRF analysis ................................110

Appendix VII. Petrographic analysis of thin-sections and classification scheme

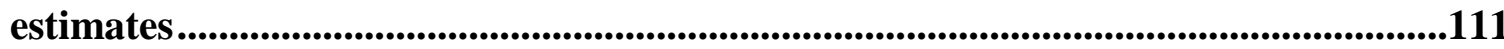

Appendix VIII. XRF major element concentrations from the MIP-3H well ........112

Appendix IX. XRF major element concentrations from the WV-6 well ..............114

Appendix X. Weathering indices and major element ratios for the MIP-3H well

Appendix XI. Weathering indices and major element ratios for the WV-6 well

Appendix XII. XRF trace element concentrations from the MIP-3H well .121 
Appendix XIII. XRF trace element concentrations from the WV-6 well .............124

Appendix XIV. Samarium-Neodymium isotopic data......................................129 


\section{ACKNOWLEDGEMENTS}

There are many people who have been invaluable to the progression and completion of both this research and my graduate education here at West Virginia University. First, I'd like to thank my parents for their support of my education and career pursuits. I would have never made it this far without their help. Special thanks to my son, Quinton, for cheering me on, providing encouraging words on rough days, and spending too many summer hours playing with legos in a lab. Thank you to Dan Segessenman and Sofia Andeksie for their editing, discussion, encouragement, and most importantly their friendship throughout my master's work. Thank you to CP Findley and Ben Johnson on their insight into provenance and discussion of my data. Special thanks to Tom Paronish for his help and comradery in working under the MSEEL project and Emily Bausher with her assistance in using ArcGIS. I would also like to thank my cohort and officemates for the laughs, beers, and collaboration throughout these years.

Thank you to my advisor, Dr. Amy Weislogel, for her guidance and support throughout this project along with an introduction into the world of mudrock provenance. Dr. Joe Donovan has been a vital resource to my education in preparing and interpreting geochemical data. Thank you for all your guidance; this project would not have progressed without you! Special thanks to Dr. Shikha Sharma and Dr. Tim Carr for support through the MSEEL project and to Shikha for serving on my committee. Thank you to Dr. Kathleen Benison and the rest of the Fall 2016 Sedimentary Petrology Class for discussion and observation of some of my petrographic data. Dr. Kitty Milliken, of UT-Austin, was an invaluable resource in understanding and interpreting my thinsections and their importance with regards to the greater context of my thesis research. 
Funding and resources for this research were provided by the Marcellus Shale Energy and Environmental Laboratory Project, a WVU Senate Research and Scholarship Grant won by Dr. Amy Weislogel, and several student grants from the Geological Society of America, American Association of Petroleum Geologists, Society for Sedimentary Geology, and the WVU Department of Geology and Geography. Special thanks to Phil Dinterman and the West Virginia Geological Survey for granting permission and giving help in sampling from the WV-6 core. Thank you to Rick Conrey and Laureen Wagoner at Hamilton Analytical Lab for braving a snow storm to get me my data, as well as Dr. Yakov Kapusta at Geochronex Analytical Services, and National Petrographic Services for their great work. Thank you to the staff of the WVU Shared Research Facilities for both training and help in using many of their instruments. And lastly, thank you to the Department of Geology and Geography for providing me with the resources and funding to pursue my education here at WVU! 


\section{LIST OF FIGURES}

Figure 1. Model of the controls on organic-matter production and preservation in marine depositional systems from Sageman et al. (2003)

Figure 2. Cross-section of the Acadian Orogeny basin model from Ver Straeten (2010)

Figure 3. Map view of Acadian Orogeny tectonic model during the Middle Devonian from Lash and Engelder (2011)

Figure 4. Paleogeographic reconstruction of Laurentia during the Middle Devonian from Blakey (2009)

Figure 5. Map of extent of Marcellus and Millboro Shale within the Appalachian Basin from Milici and Swezey (2014) and the approximate location of the study region with well locations indicated.

Figure 6. Schematic of regional stratigraphy of Middle Devonian units throughout the Appalachian Basin

Figure 7. Outcrop and core images of the Mahantango Formation

Figure 8. Outcrop and core images of the Marcellus Shale

Figure 9. Wells logs from the MIP-3H well showing distinct differences in organic content between the Marcellus Shale and Mahantango Formation.

Courtesy of Tom Paronish (2016)

Figure 10. $\quad \delta^{18} \mathrm{O}$ paleotemperature reconstruction throughout the mid Paleozoic from Joachimski et al. (2009)

Figure 11. Lower Paleozoic stratigraphy of the Valley and Ridge Province and correlative eastern Laurentian tectonic activity at time of deposition.

Figure 12. U-Pb and $\mathrm{Sm}-\mathrm{Nd}$ age map of Proterozoic and older terranes of eastern North America from Fisher et al. (2010)

Figure 13. Drone image of the MSEEL MIP-3H well site.

Figure 14. Sampling strategy for various analyses from the MIP-3H and WV-6 wells

Figure 15. Ternary diagram of thin-section samples falling under the Milliken (2014) classification system for fine-grained sedimentary rocks 
Figure 16. Ternary diagram of thin-section samples falling under the Piccard (1971) classification scheme for fine-grained rocks and sediments

Figure 17. Stratigraphic context of petrofacies identified among the thirty-six thinsections

Figure 18. Stratigraphic comparison of the petrofacies analysis of MIP-3H thin section samples and the core log description and gamma-ray log established by Paronish (2017)

Figure 19. Petrographic images of Petrofacies 1: Tarly claystone

Figure 20. Petrographic images of Petrofacies 2: Organic-rich argillaceous sarl

Figure 21. Petrographic images of Petrofacies 3: Styliolinid carl

Figure 22. Petrographic images of Petrofacies 4: Silty tarly claystone

Figure 23. Mineralogical trends from XRD analysis of the MIP-3H well samples

Figure 24. Cross-plots showing correlations among various mineral phases and key trace elements

Figure 25. Euclidean cluster analysis and mineralogical break-down of clusters of the XRD data from the MIP-3H samples

Figure 26. Mineralogical data from XRD analysis of the WV-6 well samples

Figure 27. Euclidean cluster analysis of the XRD data from the Mahantango Formation samples

Figure 28. Major element ratios ( $\mathrm{Si} / \mathrm{Al}$ and $\mathrm{Ti} / \mathrm{Al})$ in the MIP-3H and WV-6 samples

Figure 29. Major element ratios ( $\mathrm{Si} / \mathrm{Al}$ and $\mathrm{Ti} / \mathrm{Al})$ and gamma ray versus LOI crossplots

Figure 30. Various elements and oxides $\left(\mathrm{P}_{2} \mathrm{O}_{5}, \mathrm{FeO}, \mathrm{Zr}\right)$ versus LOI

Figure 31. Cross-plots of weathering indices versus calcite

Figure 32. Weathering indices from the MIP-3H and WV-6 samples

Figure 33. $\mathrm{Al}_{2} \mathrm{O}_{3}-\left(\mathrm{CaO}+\mathrm{Na}_{2} \mathrm{O}\right)-\mathrm{K}_{2} \mathrm{O}$ ternary diagram for the Mahantango Formation and Marcellus Shale samples

Figure 34. $\quad \mathrm{Al}_{2} \mathrm{O}_{3}-\left(\mathrm{CaO}+\mathrm{Na}_{2} \mathrm{O}+\mathrm{K}_{2} \mathrm{O}\right)-\left(\mathrm{FeO}_{\text {total }}+\mathrm{MgO}\right)$ ternary diagram for Mahantango Formation and Marcellus Shale samples 
Figure 35. Major element discrimination diagrams for the Mahantango Formation and Marcellus Shale

Figure 36. La-Th-Sc trace element ternary diagrams for the Mahantango Formation and Marcellus Shale

Figure 37. $\mathrm{Zr} / \mathrm{Sc}$ vs. Th/Sc cross-plots for the Mahantango Formation and Marcellus Shale

Figure 38. Graph showing the $\varepsilon_{\mathrm{Nd}}$ values yielded from the nine of the $\mathrm{Sm}-\mathrm{Nd}$ samples

Figure 39. Th/Sc vs. $\varepsilon_{\mathrm{Nd}}$ cross-plot

Figure 40. Petrostratigraphy in comparison to various proxies for organic-matter content

Figure 41. Depositional age vs. $\varepsilon_{\mathrm{Nd}}$ graph

Figure 42. Provenance interpretation map

Figure 43. Graphs showing concentrations of $\mathrm{Zr}$ and $\mathrm{Ti}$ in relation to depleted mantle model ages

Figure 44. Cross-plots of $\mathrm{Zr}, \mathrm{TiO}_{2}$, and $\tau_{\mathrm{DM}}$ 


\section{LIST OF TABLES AND EQUATIONS}

Table 1. Expected geochemical signatures of each of the three primary potential terranes

Table 2. List of ways elemental data were evaluated to determine provenance and paleoclimate signals

Table 3. Sm-Nd isotopic analysis results

Table 4. Summary table of geochemical results and their implications for the Marcellus Shale and Mahantango Formation.

Table 5. One-dimensional mixing model results of Archean and Mesproterozoic based off of $\tau_{\mathrm{DM}}$

Equation 1. Chemical Index of Alteration (CIA) from Nesbitt and Young (1984)

Equation 2. Chemical Index of Weathering (CIW) from Harnois (1988)

Equation 3. Index of Compositional Variability (ICV) from Cox et al. (1995)

Equation 4. Calculation for Discrimination Factor 1 (DF1) from Roser and Korsch (1988)

Equation 5. Calculation for Discrimination Factor 2 (DF2) from Roser and Korsch (1988)

Equation 6. Calculation for Discrimination Factor 3 (DF3) from Roser and Korsch (1998)

Equation 7. Calculation for Discrimination Factor 4 (DF4) from Roser and Korsch (1998)

Equation 8. Calculation of Sm-Nd depleted mantle model age $\left(\tau_{\mathrm{DM}}\right)$

Equation 9. Calculation of $\varepsilon_{\mathrm{Nd}}$ 


\section{INTRODUCTION}

\subsection{Research Purpose}

\subsubsection{Marcellus Shale Energy and Environmental Laboratory (MSEEL)}

The Marcellus Shale Energy and Environmental Laboratory, MSEEL, is a collaborative project between West Virginia University, Ohio State University, and the Department of Energy- National Energy Technology Laboratory (NETL). The focus of the MSEEL project is to "provide a long-term field site to develop and validate new knowledge and technology to improve recovery efficiency and minimize environmental implications of unconventional resource development” (MSEEL, 2015). Funding and resources for portions of this thesis were provided through the MSEEL project. This thesis aims to contribute to the characterization of the inorganic mineralogical constituents (i.e. clays, silts, etc.) within the Marcellus Shale from a geochemical, sedimentological, and petrographic perspective and to further the understanding of the source-to-sink relationships that produced this organic-rich, lucrative unconventional shale gas play. Three wells were drilled and monitored under the MSEEL project: one vertical well, the MIP-SW or "science well", and two horizontal wells, the MIP-3H and MIP-5H. Samples from the MIP-3H well were used to characterize and evaluate the Marcellus Shale, whereas the Mahantango Formation was explored using samples from the WV-6 well that was part of the DOE Eastern Gas Shales Program.

\subsubsection{Research Objectives}

The Middle Devonian Hamilton Group of the central Appalachian Basin in northcentral West Virginia contains two stratigraphic sub-units: the Marcellus Shale and the 
overlying Mahantango Formation. The Marcellus Shale contains organic-rich mudrock facies. While the Mahantango Formation is also composed primarily of mudrock, it does not contain abundant organic matter. Although organic matter in the Marcellus Shale has been studied extensively due to its relevance to hydrocarbon production (i.e. Harper and Piotrowski, 1978; Morshed and Tatham, 2013; Wang and Carr, 2013; Enomoto et al., 2014; Yu, 2015), little work has been done to understand the source-to-sink relationships that produced the inorganic sediments in the Marcellus Shale and associated mudrock formations.

Determining the source of the extrabasinal clastic sediment within the Hamilton Group has implications for understanding the spatial and temporal distribution of organic-matter accumulation within clay-rich depositional environments, and could aid in understanding organic-matter distribution in other potential unconventional mudrock reservoirs. Organic deposition is heavily influenced by both climate and nutrient influx to the basin (Pedersen and Calvert, 1990; Sageman et al., 2003; Arthur and Sageman, 2005; Fig. 1). Warmer, humid climates lead to increased secondary clay production primarily through hydrolysis of feldspars (Chamley, 1989; Zhou and Keeling, 2013), which can lead to increased clay-sized clastic sediment supply. Similarly, changes in source lithology due to uplift, unroofing, or drainage capture, can also alter clastic sediment flux volumes. Input of nutrients, such as nitrogen or phosphorus, are often supplied from terrestrial sediment influx to the basin, leading to increased primary biologic production. If anoxic/euxinic bottom waters exist, preservation of abundant organic matter in basin deposits can occur. However, increased terrestrial flux can also increase clay 


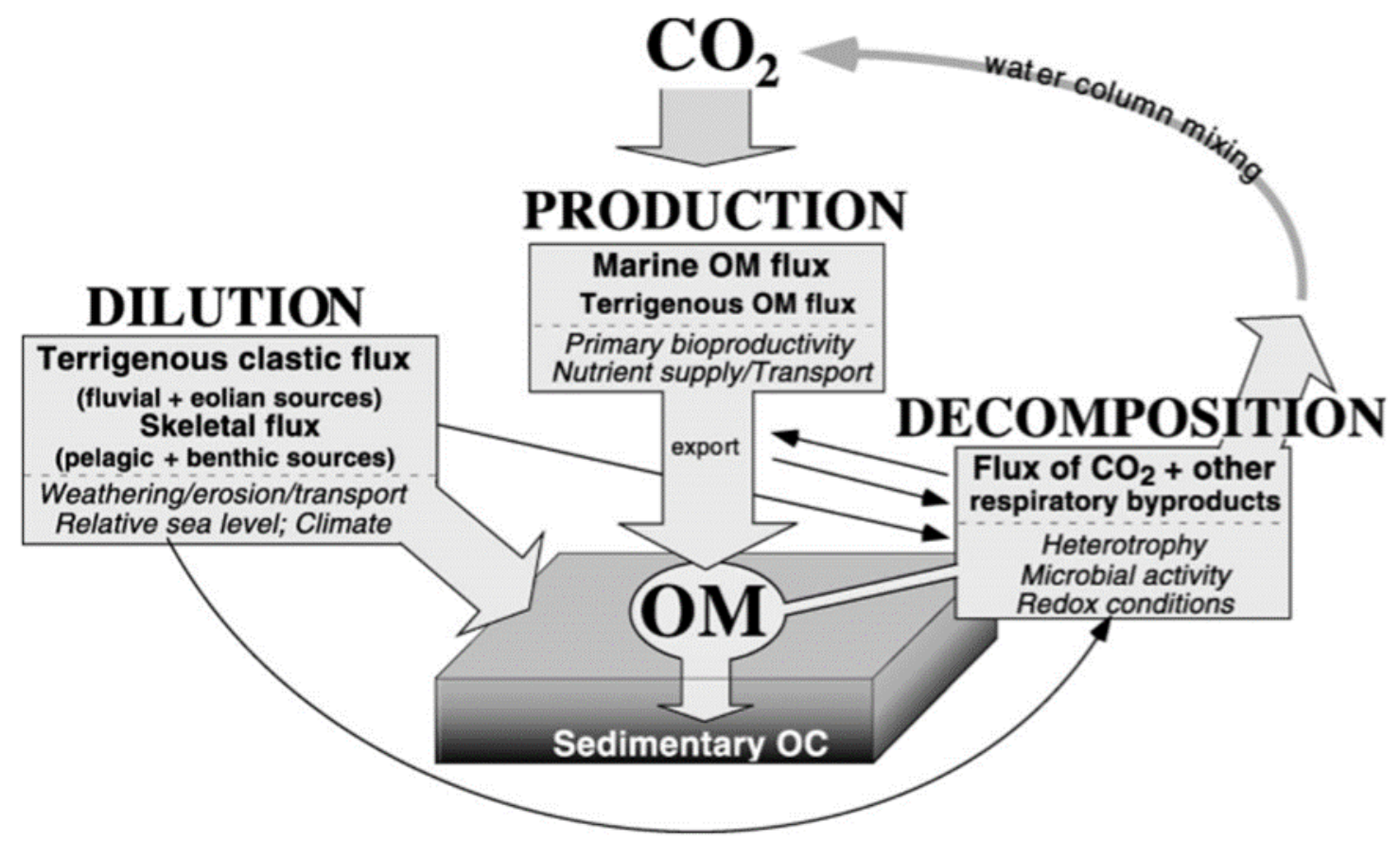

Figure 1. Model showing the dominant processes that influence both the production and preservation of organic matter (OM) in marine sediments (Sageman et al., 2003). The focus of this study is primarily on the "dilution" portion of this model by contributing to the understanding of mechanisms influencing clastic influx to the basin, specifically provenance and paleoclimate.

sedimentation in the basin, which can dilute organic-matter concentration and limit the hydrocarbon potential of mudrock deposits (Fig. 1). In addition, distance from the shoreline and fluctuations in water depth can also control the distribution of organicmatter deposition.

The Hamilton Group provides an excellent opportunity to explore the relationships between the controls on organic production/preservation in mudrockdominated strata through a comparison between the geochemical compositions of the organic-rich Marcellus Shale with the clay-rich Mahantango Formation. This up-section decrease in organic-matter content leads to the question: is the decrease in organic-matter deposition in the Hamilton Group controlled by a change in provenance that led to an increase in clay delivery to the basin? The objectives of this research are as follows: 1) to establish the provenance of clastic detritus in the Middle Devonian Hamilton Group of 
the central Appalachian Basin region and 2) to test the hypothesis that a change in clay provenance resulted in the decrease in organic-matter deposition and preservation within the stratigraphic units of the Hamilton Group.

\subsection{Geologic Background}

\subsubsection{Tectonic Setting}

The Hamilton Group is part of an eastward-southeastward thickening clastic wedge that was deposited in the retroarc foreland basin that developed due to the Acadian Orogeny (Ettensohn, 1985; Ver Straeten, 2010). Collision of the Avalonia microcontinent along the eastern margin of Laurentia from the Late Ordovician to Early Mississippian produced an orogenic belt that extended from southeastern Canada to Tennessee, and potentially as far south as Alabama (Ver Straeten, 1995; Hibbard et al., 2010; Lash and Engelder, 2011). Thrust loading, subsidence, and uplift related to the Acadian orogeny produced a foreland basin inundated by the Kaskaskia Sea, in which the Hamilton Group was deposited (Ettensohn, 2011; Ettensohn and Lierman, 2012;

Ettensohn and Lierman, 2013; Fig. 2-4).

\subsubsection{Stratigraphy of the Acadian Basin}

The Middle Devonian fine-grained sediments within the Acadian Basin vary greatly in nomenclature and surface/subsurface expression across the eastern United States. Nomenclature for these units vary throughout the Appalachian region, but is most commonly recognized as the Hamilton Group (Fig. 5). The Hamilton 


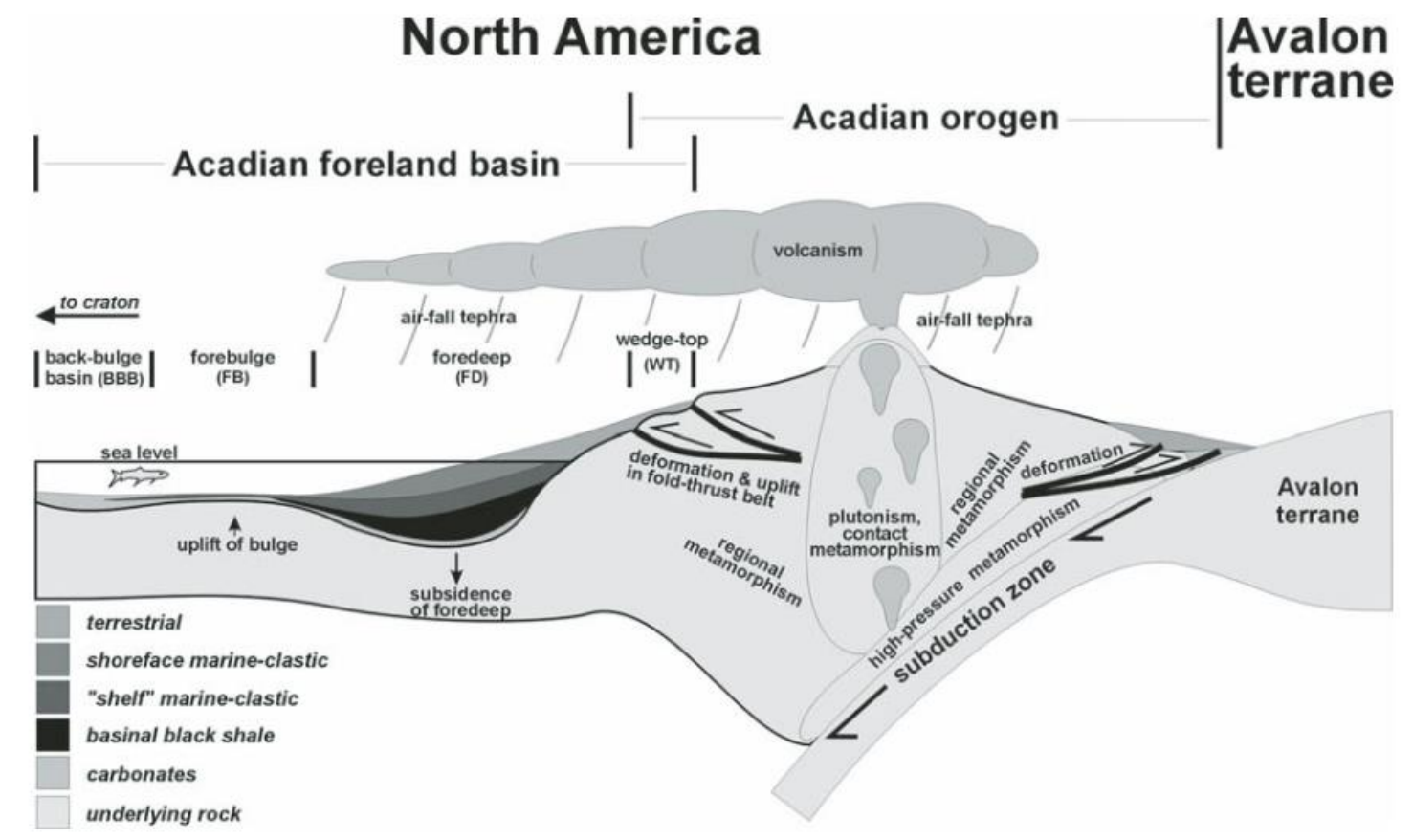

Figure 2. Cross-section of Acadian Orogeny basin model showing the formation of the foreland basin and subsequent deposition of Middle Devonian mudrock units (Ver Straeten, 2010).

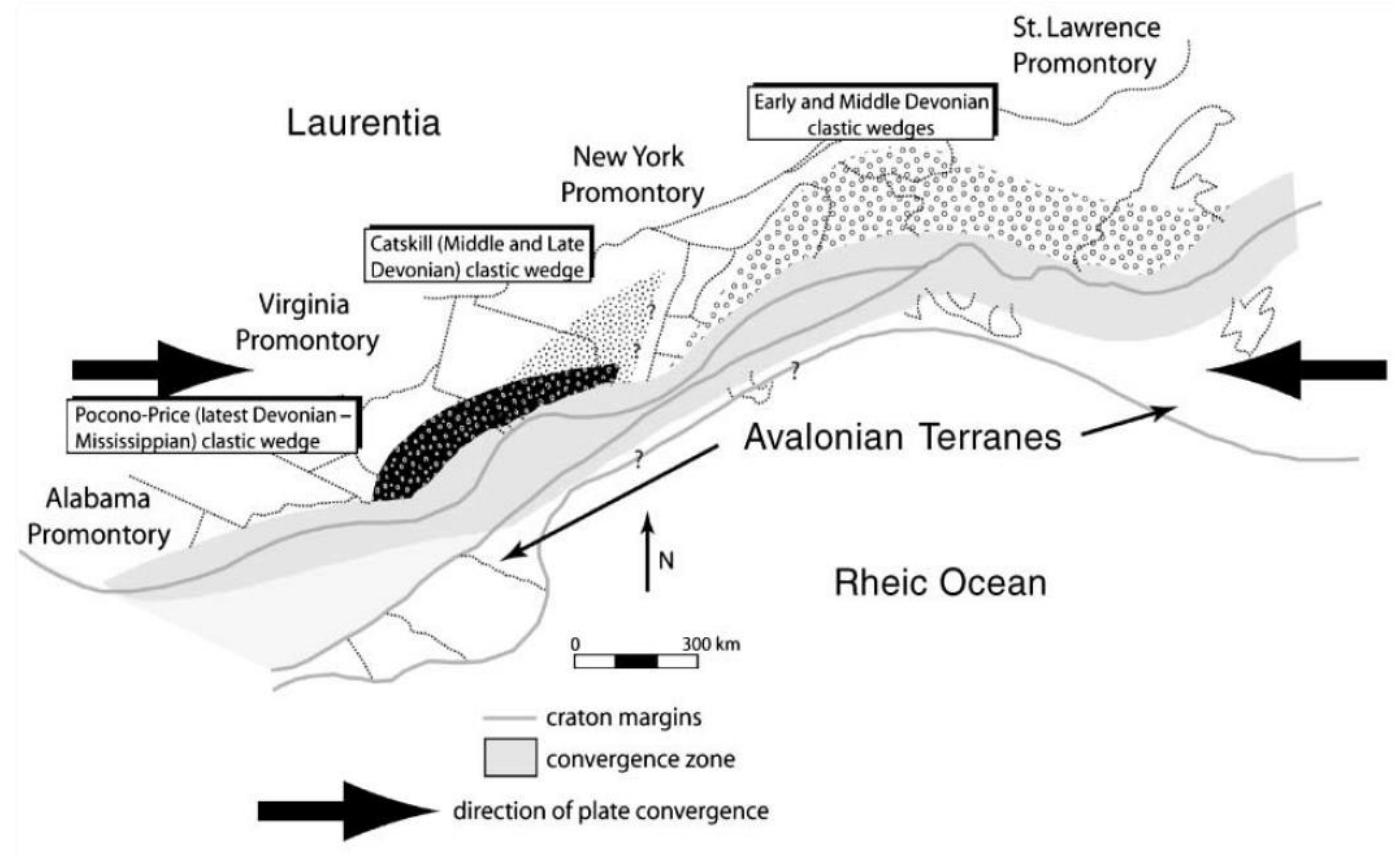

Figure 3. Map view of Acadian Orogeny tectonic model during the Middle Devonian showing plate movement and syn-orogenic deposits (Lash and Engelder, 2011). 


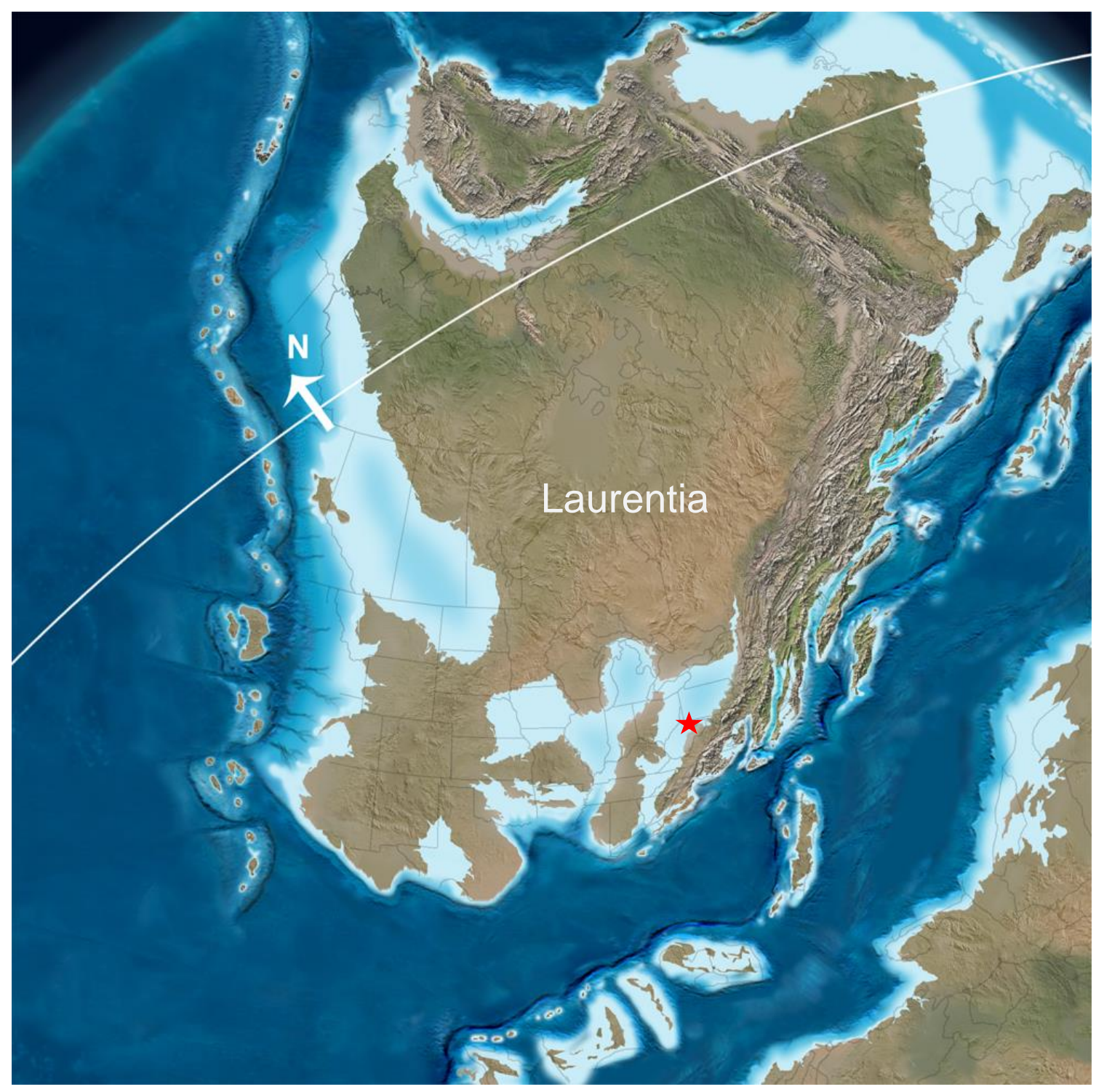

Figure 4. Paleogeographic reconstruction of Laurentia during the Middle Devonian (385 Ma) in relation to the paleoequator with the approximate location of Monongalia County, WV marked by a red star (From Blakey, 2009). 


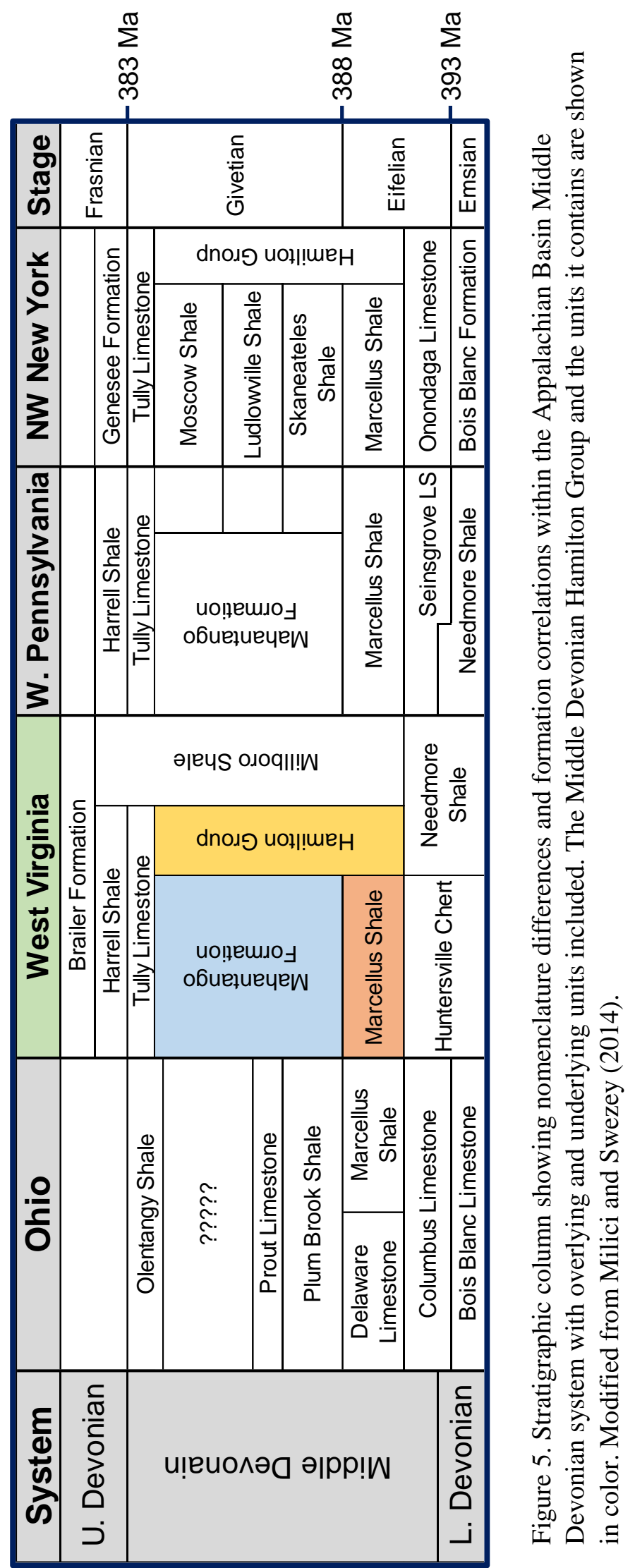


Group extends from eastern West Virginia and western Pennsylvania into Maryland and Virginia. Across West Virginia, these strata are mainly found buried in the subsurface of the Appalachian basin (Fig. 6); however, the units outcrop in the Appalachian Valley and Ridge Province of eastern West Virginia, Maryland, and northern Virginia.

Regionally, the Hamilton Group overlies the Lower Devonian (Upper Emsian to Lower Eifelien) Needmore Shale in eastern WV, Maryland, and western PA, the Huntersville Chert in WV, the Seinsgrove Limestone in eastern PA, or the Onondaga Limestone in western WV, central PA, and NY (Cleaves et al., 1968; Harris et al., 1994; Milici and Swezey, 2014). Overlying the Hamilton Group in the study area of northcentral WV is the Tully Limestone and Harrell Shale (also referred to as the Genesseo Formation in New York; Dennison and Hasson, 1976; Milici and Swezey, 2014, Soeder et al., 2014).

Within the study area, the Hamilton Group is approximately $250 \mathrm{ft}$. thick and contains the Marcellus Shale ( $100 \mathrm{ft}$.$) and Mahantango Formation ( 150 ft.; Fig. 5). The$ Marcellus Shale is a gray to black, thinly-laminated, organic-rich shale. The Tioga Ashes, also referred to as the Tioga Bentonites, are found interbedded within the basal part of the Marcellus Shale (Roen and Hosterman, 1982; Dennison and Textoris, 1988; Ver Straeten, 2004). The Marcellus Shale is gradationally overlain by the Mahantango Formation, a gray, thickly laminated, interbedded silty shale and siltstone-dominated unit (Fig. 7, 8; Dennison and Hasson, 1976; Soeder et al., 2014). The contact between these two units is difficult to identify and is often marked in well logs as a transition from high gamma ray signature of the organic-rich Marcellus Shale compared to low clay-rich gamma ray signature of the Mahantango Formation (Soeder et al., 2014; Fig. 9;). 


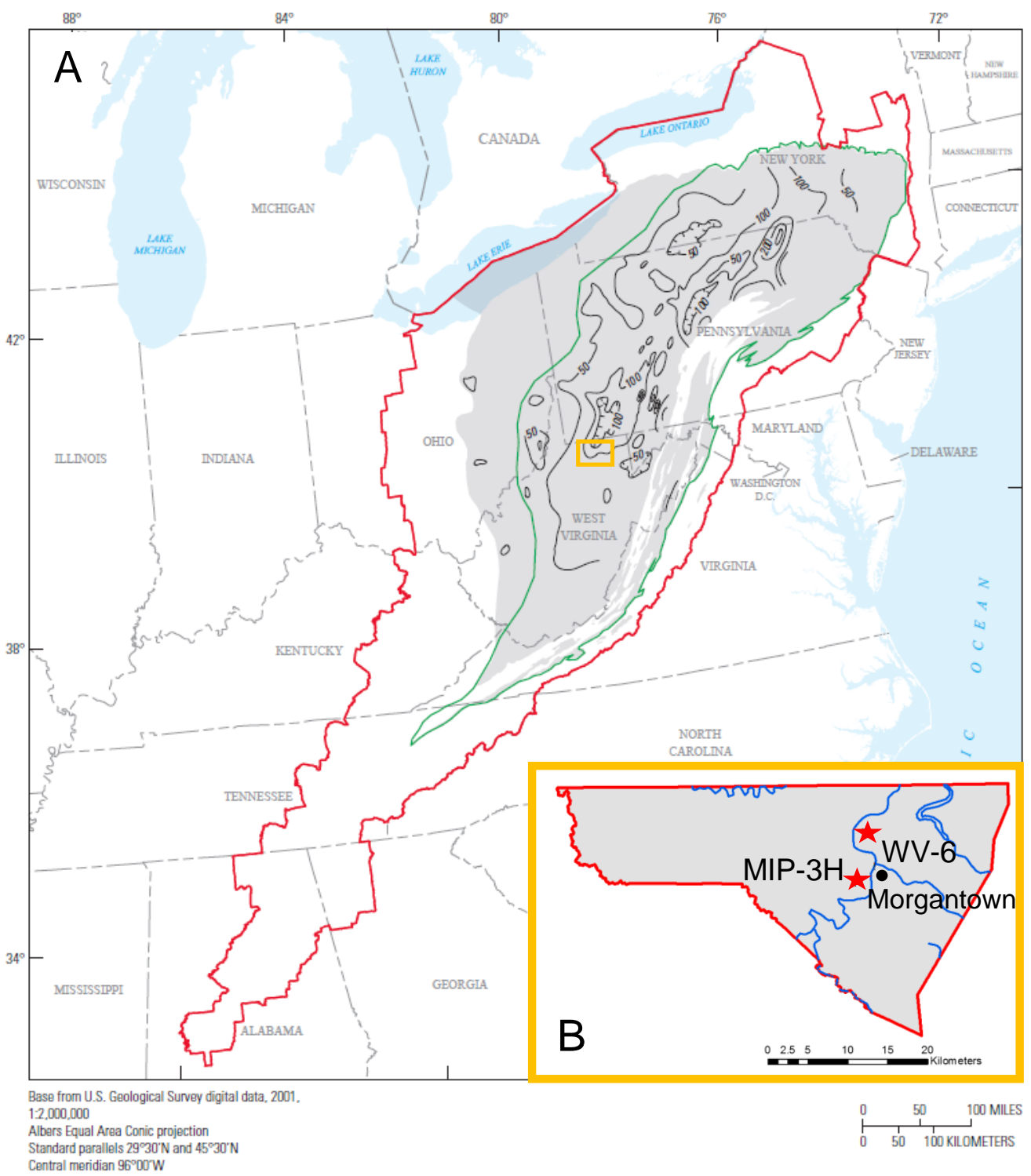

Figure 6. A: Map showing the extent and distribution of the Marcellus Shale and Millboro Formation (gray) throughout the Appalachian Basin, outlined in red. Black lines are isopachs showing the thickness of the Marcellus Shale in feet. Hachures along these isopachs indicate direction of thinning. The approximate location of the study area, Monongalia Co., WV, is indicated by the yellow box. Adapted from Milici and Swezey (2014). B: Map of Monongalia County, WV showing the location of the two wells sampled in this study. 


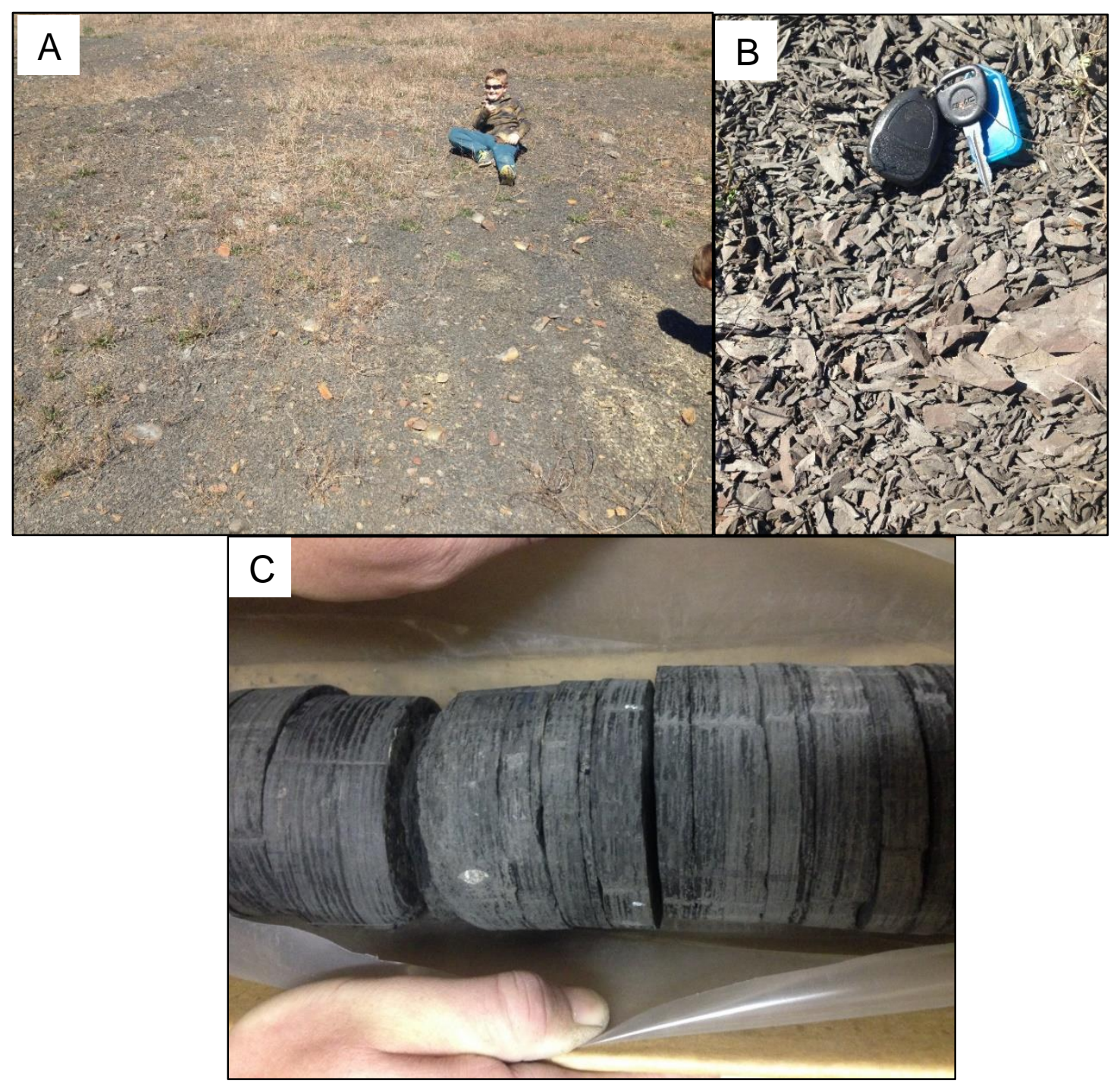

Figure 7. Images of the gray, silty shale dominated Mahantango Formation outcropping near Grant, WV (A and B) as well as a picture of the WV-6 core at $7314 \mathrm{ft}(\mathrm{C})$. 


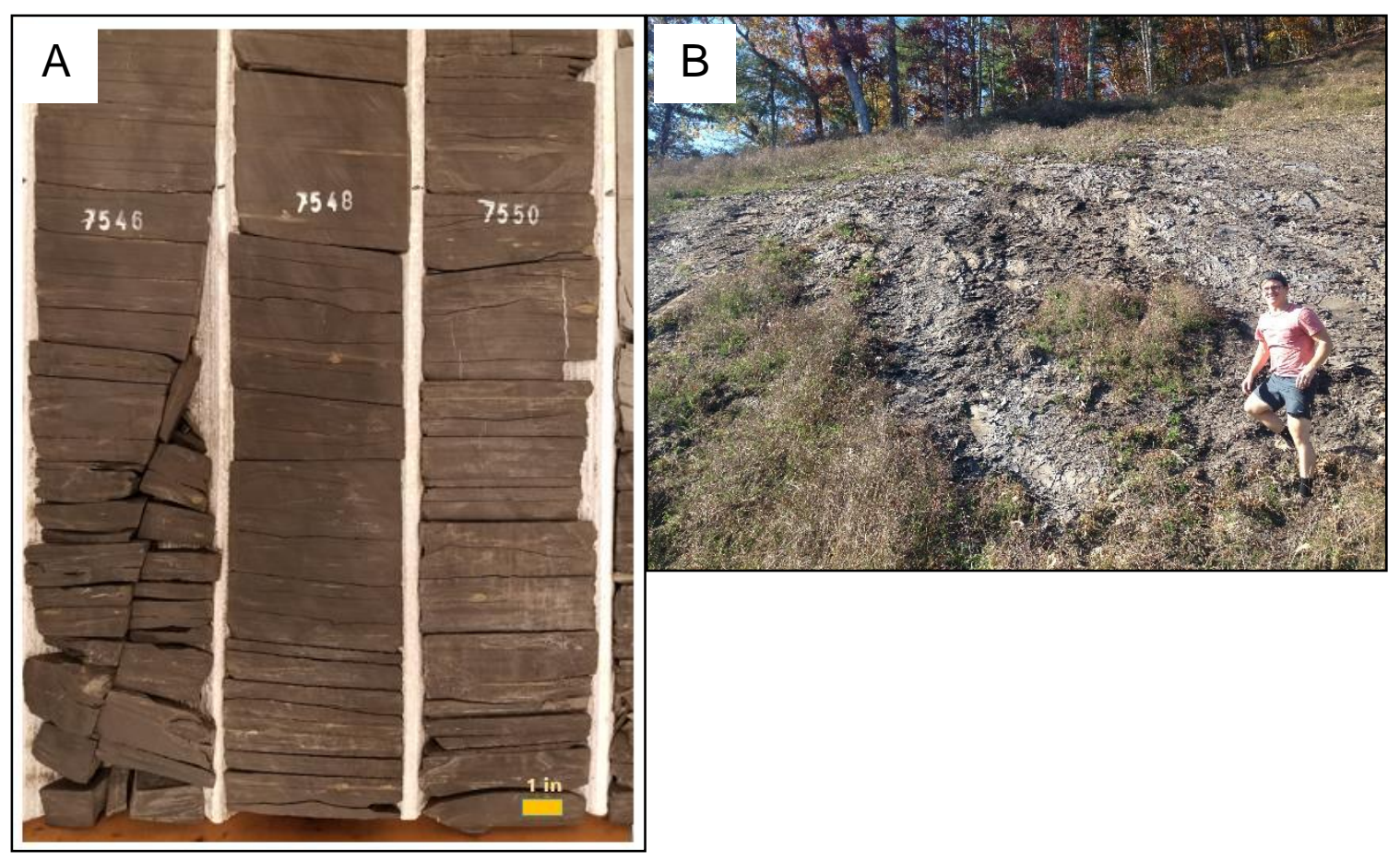

Figure 8. Image of core collected from 7546-7550 ft the MIP-3H well showing the dark black, organic-rich Marcellus Shale (A; Courtesy of Tom Paronish, 2016). Picture of the Marcellus Shale outcropping near Huntersville, WV (B).

Conodont biostratigraphy of interbedded carbonates sampled from outcrops in Pocahontas County, WV indicate the Marcellus Shale was deposited during the Eifelian to early Givetian (hemiansatus zone) and the Mahantango Formation during the Givetian (Harris et al., 1994; Repetski et al., 2013). However, zircon U-Pb ages from the Tioga Ashes sampled from wells in Taylor, Wetzel, and Harrison counties in West Virginia, yielded ages ranging from 394 to $389 \mathrm{Ma}$, indicating late Emsian to Late Eifelian deposition of the Marcellus Shale (Parrish, 2013). Based on these age estimates, the Hamilton Group records approximately 11 million years of deposition during the Devonian time period.

In north-central West Virginia, the Hamilton Group overlies the Onondaga Limestone. Within the MIP-3H core obtained through the MSEEL project, this contact 


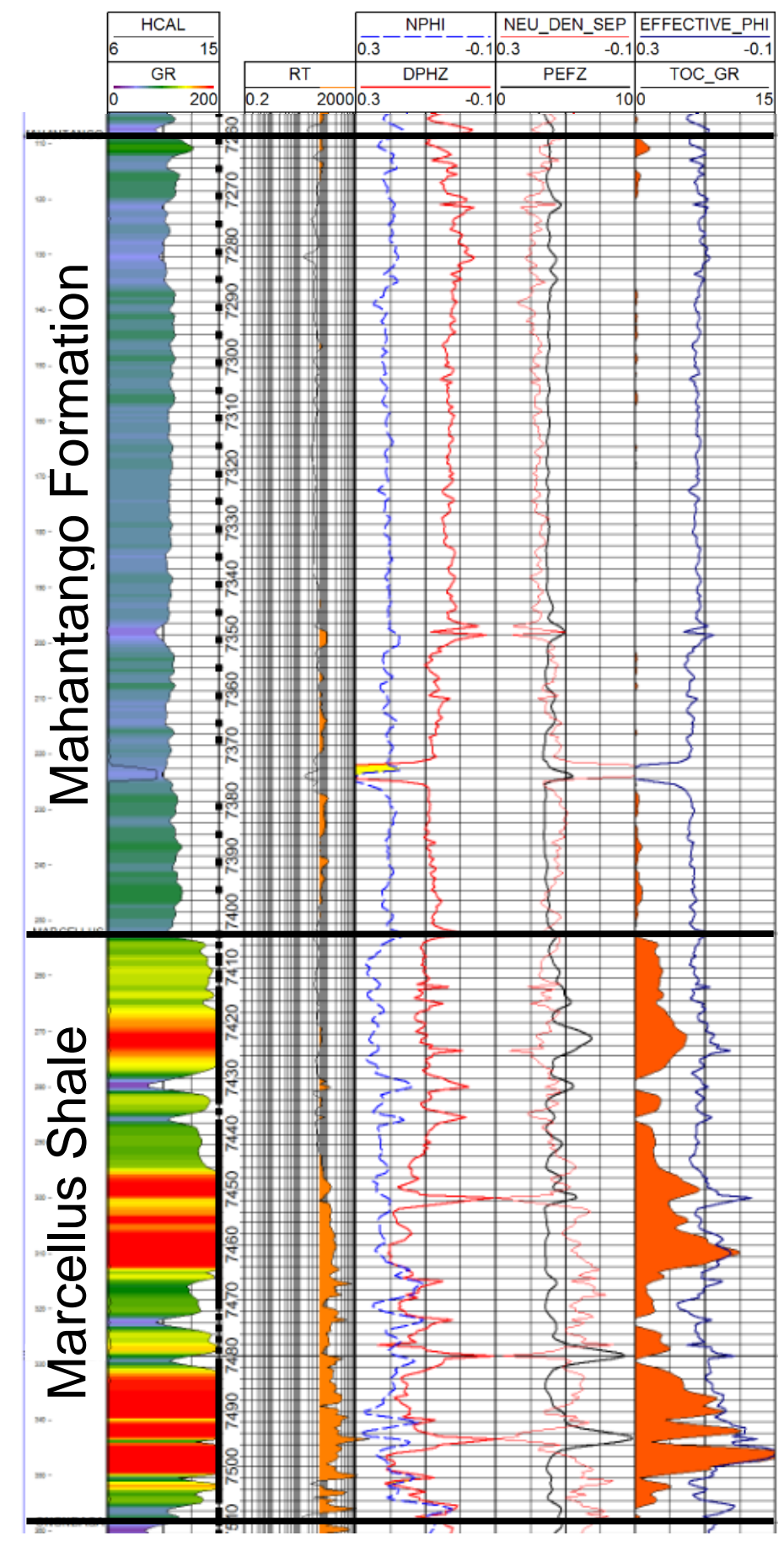

Figure 9. Well logs from the MIP-3H well, showing the Mahantango Formation and Marcellus Shale intervals. Well logs from left to right include caliper, gamma ray, resistivity, neutron porosity, density porosity, neutron-density separation, and photoelectric. The black dots marked to the right of the gamma ray indicate where core plugs were collected as part of the MSEEL project. Note the distinct differences in both the gamma-ray and TOC logs between the Marcellus Shale and overlying Mahantango Formation. Logs courtesy of T. Paronish (2017). 
appears as a lithologic transition from fossiliferous limestone of the Onondaga Limestone to the overlying black shale of the Marcellus Shale. The contact between the Marcellus Shale and Mahantango Formation in both sampled wells was determined by the distinct transition from high to low gamma ray. The Tully Limestone gradationally overlies the Mahantango Formation and is identified in the WV-6 core by the transition into a lightercolored carbonate-rich lithology.

\subsubsection{Devonian Paleoclimate}

Paleoclimate is often indicated as a primary control on the deposition of organic matter in the Hamilton Group (Sageman et al., 2003; Emmanuel, 2014). Several studies have characterized global temperature variations throughout the Devonian. Joachimiski et al. (2009) measured $\delta^{18} \mathrm{O}$ from hundreds of Devonian conodonts across Europe, North America, and Australia (Fig. 10). These measurements support the interpretation of warm, tropical temperatures $\left(\sim 30^{\circ} \mathrm{C}\right)$ globally during the Early Devonian (Lochkovian), to cooler temperatures during the Middle Devonian $\left(\sim 23-25^{\circ} \mathrm{C}\right)$ recognized by an enrichment in $\delta^{18} \mathrm{O}$, followed by a temperature increase back to $30^{\circ} \mathrm{C}$ at the FrasnianFamennian transition. Carbon cycle modeling of organic carbon burial and atmospheric $\mathrm{CO}_{2}$ based on $\delta^{13} \mathrm{C}$ and $\delta^{34} \mathrm{~S}$ measurements of marine carbonates from central and southern Europe and marine sulfates from Canada, Australia, Russia, Ukraine, Belgium, France, and Bulgaria indicate Early Devonian temperatures ranged from $27^{\circ}$ to $30^{\circ} \mathrm{C}$, Middle Devonian temperatures ranged from $25^{\circ}$ to $28^{\circ} \mathrm{C}$, and Late Devonian temperatures ranged from $26^{\circ}$ to $29^{\circ} \mathrm{C}$ (Simon et al., 2007). Simon et al. (2007) attributed the average $\sim 2^{\circ} \mathrm{C}$ cooling to organic carbon burial and silicate weathering, leading to a 


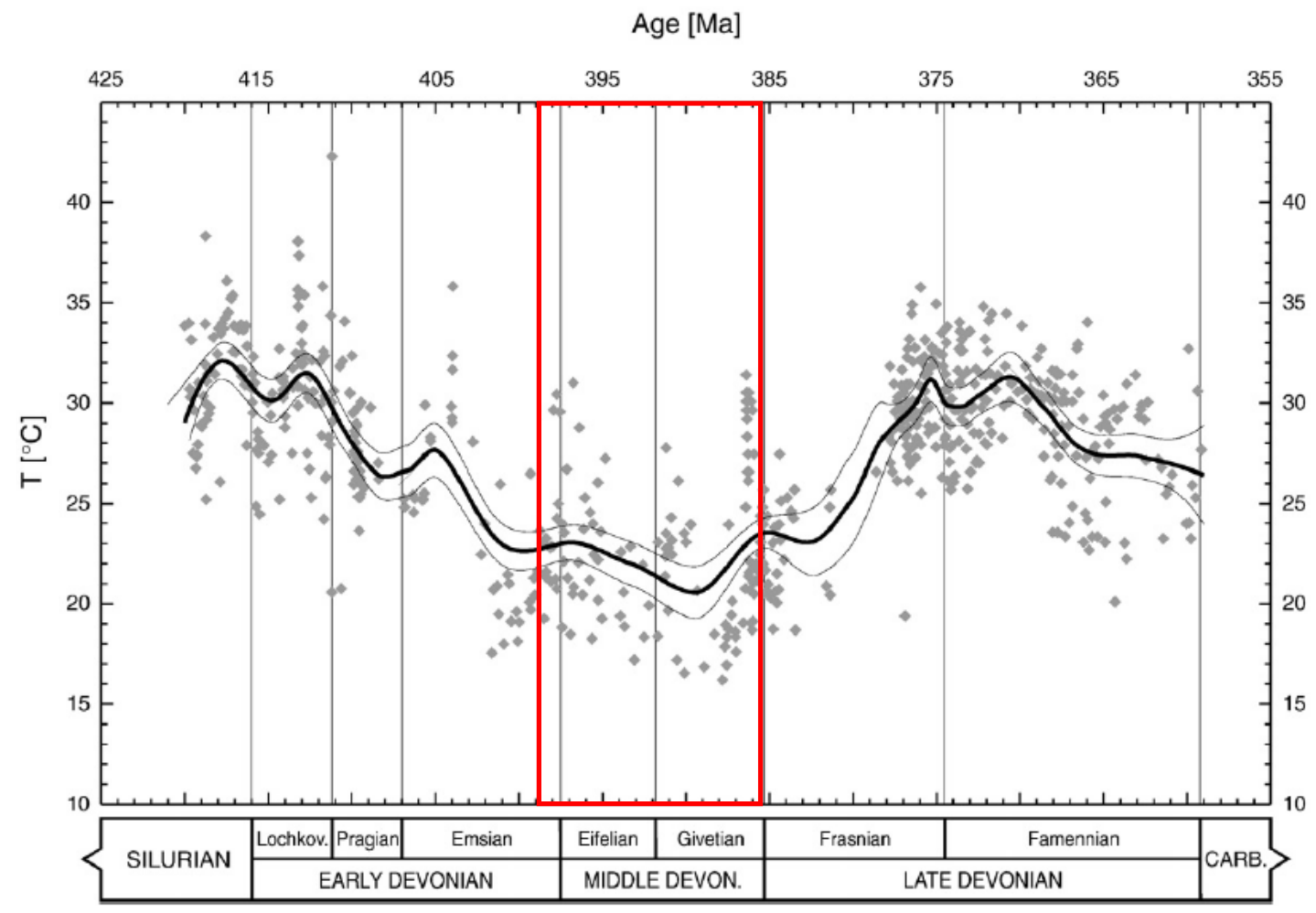

Figure 10. Paleotemperature reconstruction from Paleozoic conodont apatite $\delta^{18} \mathrm{O}$ measurements$1 \%$ VSMOW. The period of deposition for the Hamilton Group has been denoted by the red box. Note the decrease in global temperatures throughout the Eifelian into the Early Givetian, followed by an abrupt increase in global temperatures from the Middle to Late Givetian. (Joachimski et al., 2009).

drawdown in atmospheric $\mathrm{CO}_{2}$. The aforementioned studies support global cooling during the Eifelian into the beginning of the Givetian during deposition of the Hamilton Group. This cooling period was followed by global climate warming throughout the middle Givetian into the Frasnian.

In the region of the study area, $\delta^{13} \mathrm{C}$ composition of Devonian land plants have been extensively studied throughout the northern and central Appalachian Basin, including outcrops from north-central Pennsylvania, eastern New York, and northern Ohio (Wan, 2012). Several paleoclimate study localities as far north as Quebec and New Brunswick, and as close as 50 miles south of the study area as Elkins, West Virginia, 
provide insight into paleoclimate fluctuations within the north-central Middle Devonian Acadian Basin. Results indicate that on average, the $\delta^{13} \mathrm{C}$ values were 3-4 \%o higher during the Middle Devonian than the Early and Late Devonian (Wan, 2012). This trend implies lower atmospheric $\mathrm{CO}_{2}$ and a cooler climate during the Middle Devonian compared to the Early and Late Devonian. During the deposition of the Marcellus Shale, temperatures dropped from $\sim 23.5^{\circ} \mathrm{C}$ to $21^{\circ} \mathrm{C}$ (Wan, 2012). Temperatures continued to drop into the mid-Givetian and then rose, ranging from $\sim 20^{\circ} \mathrm{C}$ to $\sim 23.5^{\circ} \mathrm{C}$ during the deposition of the Mahantango Formation. Overall, these paleotemperatures are consistent with the sub-tropical paleolatitudinal interpretation of the basins paleogeographic location, approximately $25-30^{\circ}$ south of the paleoequator (McKerrow and Scotese, 1990).

\subsection{Previous Studies}

\subsubsection{Provenance Terranes surrounding the Middle Devonian Acadian Basin}

Epeiric seas occupied regions west of the Acadian Basin and were dominated by carbonate deposition (Johnson, 1974; Blakey, 2009); thus, there was likely minimal input of detrital clay from western sources. Instead, provenance of the Hamilton Group could have been associated with three potential sediment sources, or provenance terranes adjacent to the Acadian Basin: 1) the Acadian arc to the east, 2) the Acadian fold-thrust belt to the east, and 3) the Superior Craton to the north (Table 1). Additionally, sediment influx could have been sourced from the Grenville and Taconic orogenic rocks exposed in the remnants of the Taconic Highlands. These potential source terranes vary in lithology, age, and geochemical compositions. 


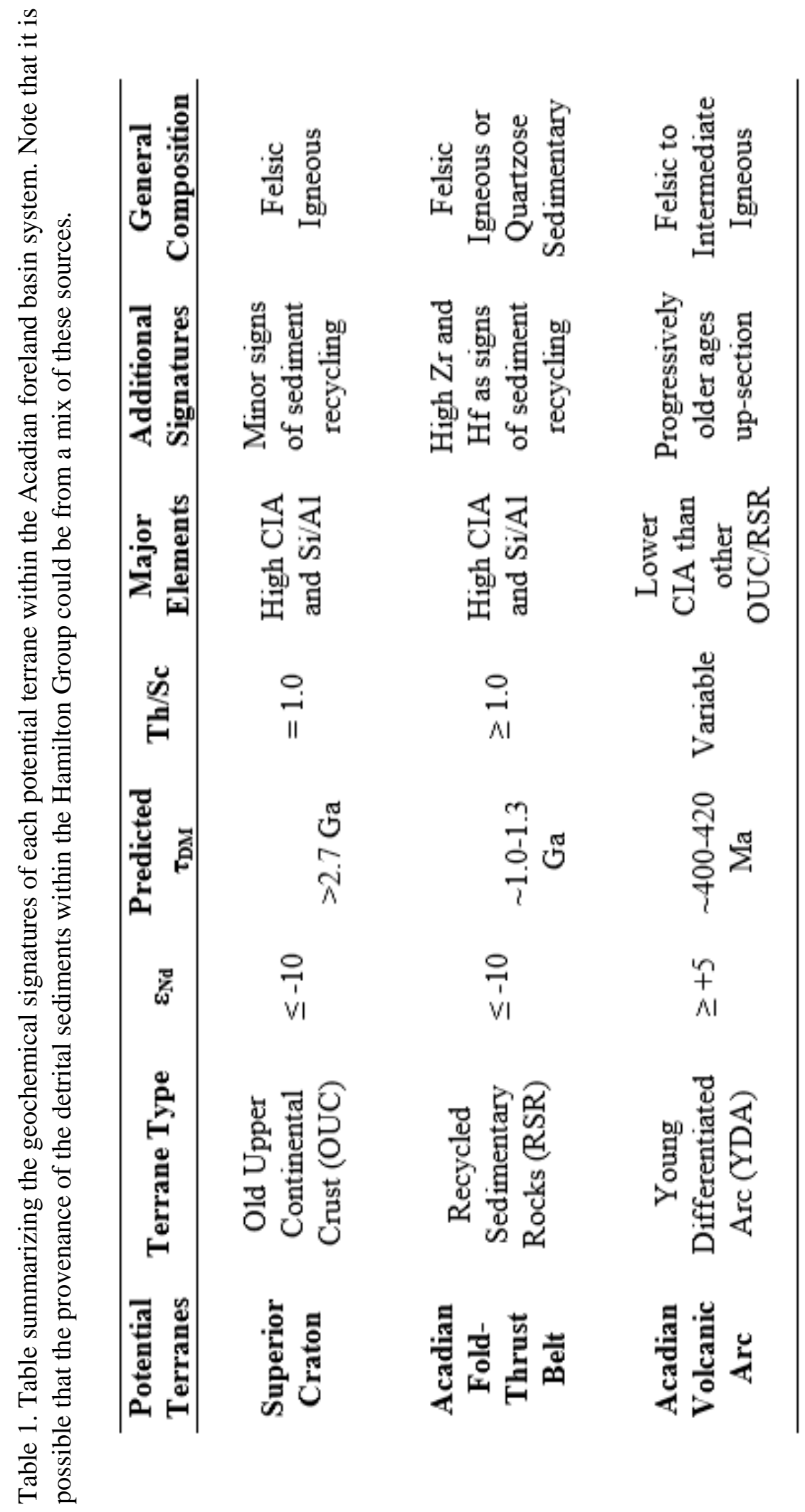


The Acadian arc was located to the east of the Acadian Basin during the Middle Devonian (Fig. 2-4). Ash beds, known as the Tioga Ashes, found intermittently throughout the lower Marcellus Shale and underlying Onondaga Limestone, show air-fall volcanic input from this coastal volcanic arc during time of deposition. U-Pb zircon ages from these ash layers show periodic volcanic activity ranging from the Late Emsian ( 394 Ma) to Late Eifelian ( 389 Ma) (Tucker et al., 1998; Ver Straeten, 2002; Parrish, 2013). In addition to distributing ashes across the southeastern surface of Laurentia, the Acadian arc magmatism generated internal felsic to intermediate melts (van Staal et al., 2011; Parrish, 2013). Syn-orgogenic magmatic granitoid rocks formed from the partial melting of subducted fore-arc material associated with flat slab subduction and show U$\mathrm{Pb}$ zircon ages ranging from approximately 420-400 Ma (van Staal et al., 2009; Sinha et al., 2010). Sm-Nd studies of syn-orgogenic volcanic rocks in Maine yielded $\tau_{\mathrm{DM}}$ ages ranging from $\sim 403-417 \mathrm{Ma}$ (Schoonmaker et al., 2011). Weathering and unroofing of the Acadian arc would produce sediment with geochemically felsic to intermediate composition. Erosion of Acadian volcanic and plutonic rocks would yield first-cycle sediment with low CIA values compared to sediment derived from highly-weathered cratonic or recycled sedimentary rocks.

Sediment influx from the Acadian fold-thrust belt would show a recycled sedimentary source rock geochemical signature. The Acadian fold-thrust belts lay to the east-northeast of the basin and extended from New Brunswick to Alabama (Fig. 2-4). Early Devonian ( 400 Ma) to Grenville aged ( $1250 \mathrm{Ma})$ rocks were thrust westward during the Acadian Orogeny (Fig. 2 and 11). The Acadian fold-thrust belt consists of Precambrian through Devonian strata; however, much of the Lower Paleozoic strata are 
carbonate rocks which could not supply a significant influx of clay minerals to the Acadian foreland. The Taconic foreland basin deposits that formed during the Ordovician are primarily quartzolithic in composition. Detrital zircon analysis and $\mathrm{Sm}-\mathrm{Nd}$ isotopic analysis from Taconic flysch indicate sediment input from erosion of rocks from the Grenville terrane ( 1.0-1.3 Ga; Anderson and Samson, 1995; Scott et al., 2016). Silurian and Early Devonian sandstones (e.g., Tuscarora Sandstone, Rose Hill Formation, Keefer Sandstone, Oriskany Sandstone) also show detrital-zircon provenance indicating dominantly Grenville (1330-1560 Ma) sediment sources, though a few 553 Ma zircon grains within the Tuscarora Sandstone indicate younger Neoproterozoic rocks of periGondwanan origin also provided sediments (Thomas et al., 2014). These rocks uplifted in the Acadian fold-thrust belt would generate a recycled orogenic source provenance signature (Dickinson et al., 1983).

Overall, erosion of rocks from the adjacent fold-thrust belt to the east of the Acadian basin would generate sediment with highly-evolved major element abundances (McLennan et al., 1993). Sediment influx from the fold-thrust belt would yield higher $\mathrm{CIA}$ and $\mathrm{Si} / \mathrm{Al}$ values than first-cycle sediment derived from granitic or metamorphic rocks. The $\varepsilon_{\mathrm{Nd}}$ values for recycled sedimentary rock sources (RSR) typically are $\leq-10$ (McLennan et al., 1993). Input from a RSR source would also likely show enrichment of elements associated with refractory heavy minerals that typically survive multiple episodes of weathering and erosion; for example, abundant zircon would cause abundant $\mathrm{Zr}$ and Hf.

Cratonic sources to the north-northwest serve as the last potential source terrane. The Superior Craton lies north of the Devonian Acadian Basin and has been tectonically 
stable since the Archean (Canil, 2008). The Superior Craton formed primarily as crustderived granodioritic plutons during the Archean (Percival et al., 2012; Jaupart et al., 2014). Sm-Nd isotopic dating of the craton has yielded depleted mantle model ( $\left.\tau_{\mathrm{DM}}\right)$ ages

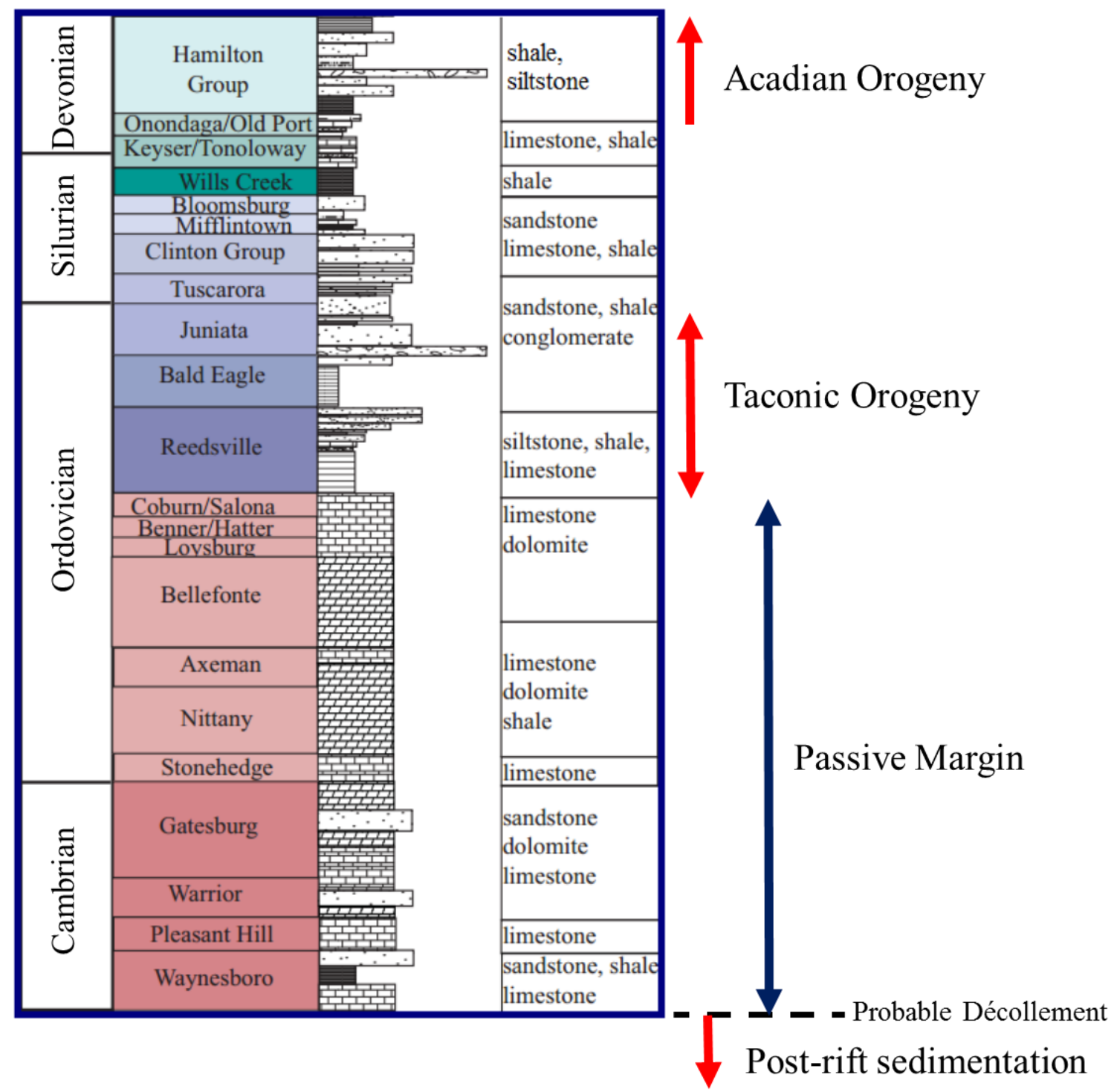

Figure 11. Stratigraphy of the Valley and Ridge Province of the Appalachian Mountains, showing Lower Paleozoic sedimentary units that were likely part of the Acadian fold-thrust belt. The dashed line indicates the probable décollement of these thrust sheets. Red arrows indicate activity along the eastern margin of Laurentia throughout the Lower Paleozoic, while the blue arrow indicates an extended period of eastern Laurentia being a passive margin. Adapted from Sak et al. (2012). 


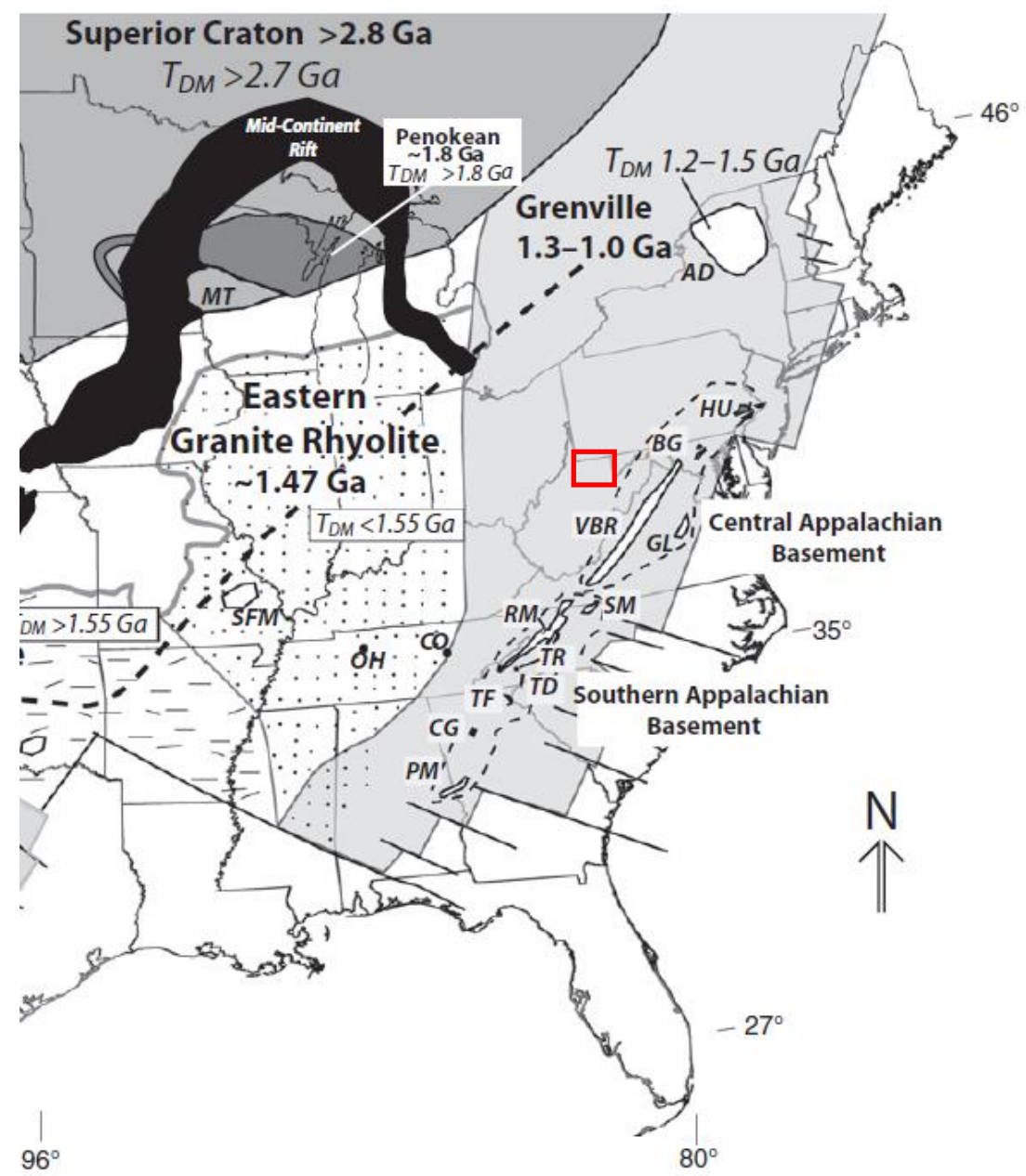

Figure 12. Generalized map of Proterozoic and older terranes of eastern North America, established through $\mathrm{U}-\mathrm{Pb}$ zircon ages and $\mathrm{Sm}-\mathrm{Nd}\left(\mathrm{T}_{\mathrm{DM}}\right)$ depleted mantle model ages. Abbreviated terranes are as follows: AD-Adirondacks; BG-Baltimore Gneiss; CO-Crab Orchard; CG- Corbin Gneiss; GL-Goochland terrane; OH- Old Hickory; HU-Honeybrook; RM-Roan Mountian, SFMSt. Francois Mountains; SM-Sauratown Mountain window; TD-Toxaway dome; TF-Tallulah Falls dome; TR- Trimont Ridge; VBR-Virginia Blue Ridge (Fisher et al., 2010) Note the location and age of Grenville terranes along the eastern side of the basin and Superior Craton terrane to the north of the paleo-basin. The study area for this research is indicated by the red box.

ranging from 2.7 to $3.1 \mathrm{Ga}$, with an average $\tau_{\mathrm{DM}}$ age of $\sim 2.8 \mathrm{Ga}$ (Fig. 12; Percival et al., 2006; Fisher et al., 2010; Percival et al., 2012). The Superior Craton serves as an old upper-continental crust source (OUC), likely exhibiting highly-evolved major elements 
(i.e. $\mathrm{Si} / \mathrm{Al}$ ratios) which would reflect both the dominantly granodioritic composition and intense weathering history associated with the older age of the source. Overall, these rocks tend to display signatures of felsic/granitic composition with additional signs of sediment recycling and old depleted mantle model ages of >2.7 Ga (Fisher et al., 2010; Percival et al., 2006; Percival et al., 2012).

\subsubsection{Previous provenance analysis of Acadian syn-orogenic sediments}

Only one previous study has investigated provenance of the Marcellus Shale in the central Appalachian Basin region. Gardiner et al. (2012) sampled a core drilled in Greene County of southwestern Pennsylvania to conduct Sm-Nd isotopic dating on the detrital sediments and $\mathrm{U}-\mathrm{Pb}$ dating on zircons within the ash beds of the Marcellus Shale. Their results yielded $\mathrm{Nd}$ depleted mantle model ages of 1.4 to $1.6 \mathrm{Ga}$ to which they attributed to detrital sediments being dominantly sourced from Acadian orogenic highlands to the east. Zircon crystals in the ash exhibited inherited cores that yielded U$\mathrm{Pb}$ ages of $\sim 1.0 \mathrm{Ga}$, suggesting the volcanic magmatic system assimilated rocks of Grenville basement (Gardiner et al., 2012). Zircon from ash beds of the lower Marcellus in West Virginia were similarly found to contain inherited cores with Grenville U-Pb ages (Parrish, 2013; Hayward, 2012).

Many studies have evaluated provenance of the Hamilton Group in New York given the subsurface thickness and abundant surface exposures of this unit throughout the state. Ver Straeten and Sageman (1999a, 1999b) investigated 600 m of mudrockdominated core from the Middle Eifelian Onondaga Limestone to the Upper Fammenian Gowanda Shale from western New York. Average elemental geochemical compositions were similar to upper-continental crust with few samples suggesting an andesitic to 
basaltic source rock. Elemental trends reflected an increasing felsic input up-section. Ver Straeten and Sagemen (1999a, 1999b) attribute the origin of these fine-grained sediments to the unroofing of the Acadian arc with recycled input from the adjacent hinterland. Middle and Upper Devonian shales of western and central New York were analyzed by Caesar et al. (2010a, 2010b) for major, trace, and rare earth element chemistry, as well as Sm-Nd isotopic composition. The results of their analyses yielded model ages $\left(\tau_{\mathrm{DM}}\right)$ ranging from $946 \mathrm{Ma}$ for the Union Springs Member, the lowest member of the Marcellus Shale, to 1504 Ma in the Marcellus Shale itself (Caesar et al., 2010a; Caesar et al., 2010b). Both the older $\tau_{\mathrm{DM}}$ model ages and evidence of a highly-weathered and wellmixed source from REE and trace element geochemistry led Caesar et al. (2010a) to interpret their data as supporting a dominantly Archean Canadian Shield sediment influx from the north, with input from the Catskill Mountains to the east. Mosher et al. (2010) conducted a similar study on the Union Springs member of the Marcellus Shale in New York, establishing the major, minor, and trace elemental chemistry with Nd-model ages that indicate a Precambrian source rock (1504-1689 Ma; Mosher et al., 2010).

Detrital zircons sampled from the Marcellus Shale of New York were found to be dominantly 950-1350 Ma (Grenville orogeny) or 400-450 Ma (Taconic/early Acadian), with minor populations of 550-700 Ma (Brasiliano/Pan-African), 1400-1500 Ma (Granite-rhyolite Province), 1800-1950 Ma (Trans-Hudson/Penokean Provinces), and 1600-1800 Ma (Yavapai/Mazatzal; Selleck et al., 2014). Selleck et al. (2014) suggested that the Marcellus Shale was deposited during early stages of basin-filling due to input from both cratonic and reworked passive margin sources. Grenville zircons found within their older sampled strata showed a bias toward younger Grenville ages, providing 
evidence for potential unroofing of the Grenville terrane during the deposition of the Marcellus Shale (Selleck et al., 2014). Additional detrital zircon provenance analysis of the Marcellus Subgroup in the Catskill region of New York suggested that the provenance of the Marcellus Shale was dominated by Laurentian source rocks, with younger Grenville zircons from the Ottawan Orogeny (1080-1020 Ma) being the most abundant (Selleck et al., 2016). In comparison, the younger Givetian clastics of the Manorkill Formation in the Catskill region, which are correlative to the upper Mahantango Formation, were also dominated by Grenville zircon ages, but showed a larger population of syn-orogenic zircon from the Acadian Orogen (470-420 Ma). 


\section{RESEARCH}

\subsection{Sampling}

Two wells were sampled in order to analyze both the Marcellus Shale and the Mahantango Formation. Only samples from the Marcellus Shale were available from the MIP-3H well of the MSEEL project. Therefore, the nearest well with available core, WV6, was used to sample throughout the Mahantango Formation.

\subsubsection{MSEEL: MIP-3H}

The MIP-3H horizontal well was drilled near Morgantown, Monongalia County, West Virginia along the western side of the Monongahela River (Fig. 6). Sixty-two samples were collected from side-wall plugs from the MIP-3H well (API \# 47061017050000) as part of the MSEEL drilling project (Fig. 13-14). Side wall plugs ranged in weight from $\sim 10-50 \mathrm{~g}$ and were collected at variable intervals, ranging from every 0.5-8.5 ft., with an average sampling interval of $1.7 \mathrm{ft}$., throughout the entire $108 \mathrm{ft}$. of sampled section. Of the 62 samples, 6 were collected from the bottom of the Mahantango Formation, whereas the other 56 were from the Marcellus Shale. Aliquots of all 62 samples were analyzed by XRD for bulk mineralogy and XRF for major and trace elemental composition, 25 were made into thin-sections, and 6 were analyzed for $\mathrm{Sm}-\mathrm{Nd}$ whole-rock isotopic analysis (Fig. 14).

\subsubsection{WV-6}

Fifty-nine samples were collected from core recovered from the WV-6 well (API \#: 47061003700000) that is archived by the West Virginia Geological Survey. The WV-6 


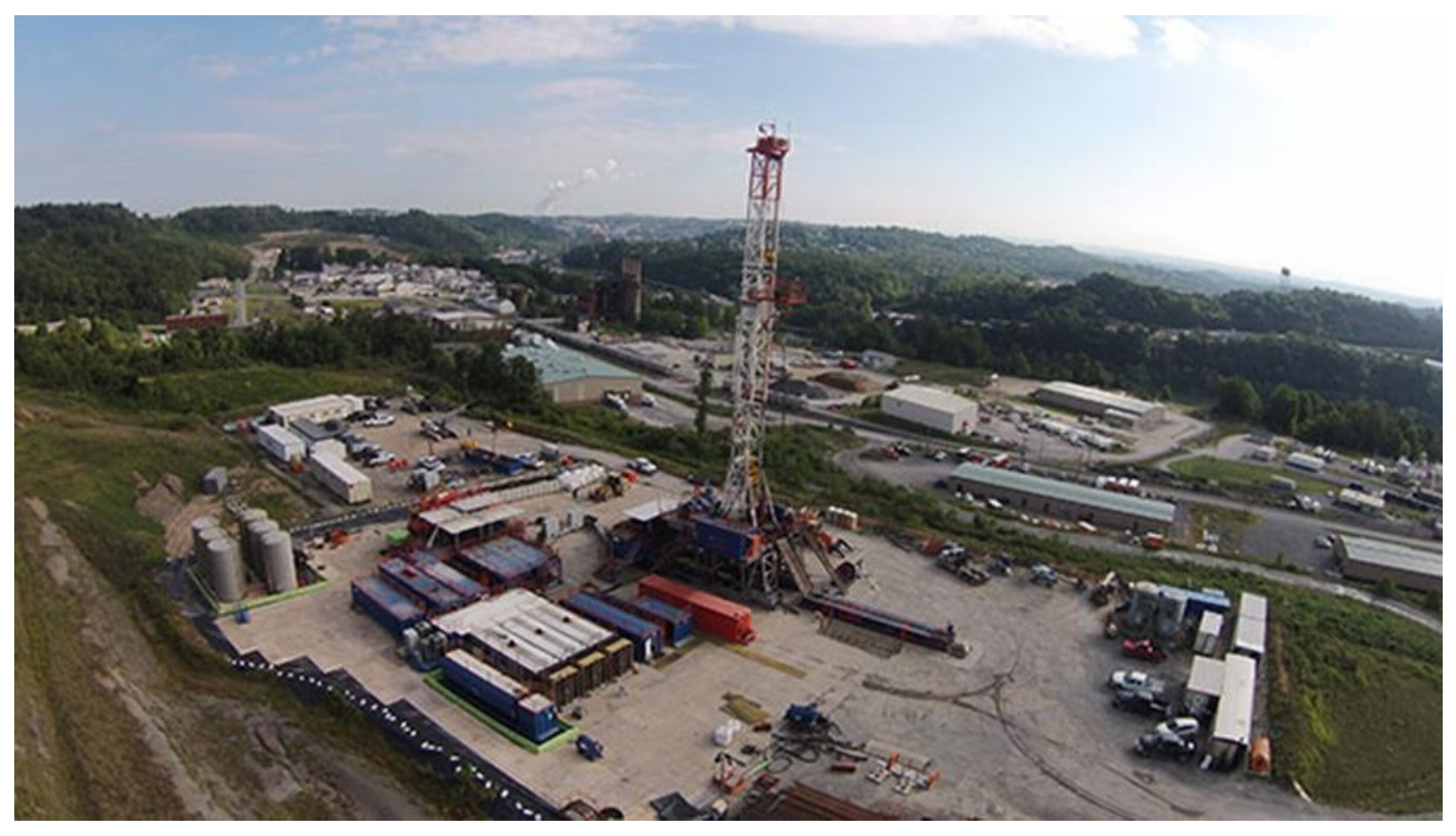

Figure 13. Drone image of the MSEEL site, just south of Morgantown, WV. (mseel.org, 2015)

well was drilled within Monongalia Co. approximately four miles toward the north from the MIP-3H well (Fig. 6). These samples ranged from $\sim 30-100 \mathrm{~g}$ and were collected approximately every $3 \mathrm{ft}$. throughout the Mahantango Formation (58 samples) and includes one sample from the uppermost Marcellus Shale. All 59 samples were analyzed via XRD bulk mineralogy and XRF for major and trace element geochemistry, 11 were made into thin-sections, and 4 were analyzed for Sm-Nd whole rock isotopic dating (Fig. 14). The Marcellus Shale section of the WV-6 well has been extensively sampled for various geochemical analyses (stable isotopes, major and trace elements, REE, etc.) and studied by Chen (2016). 


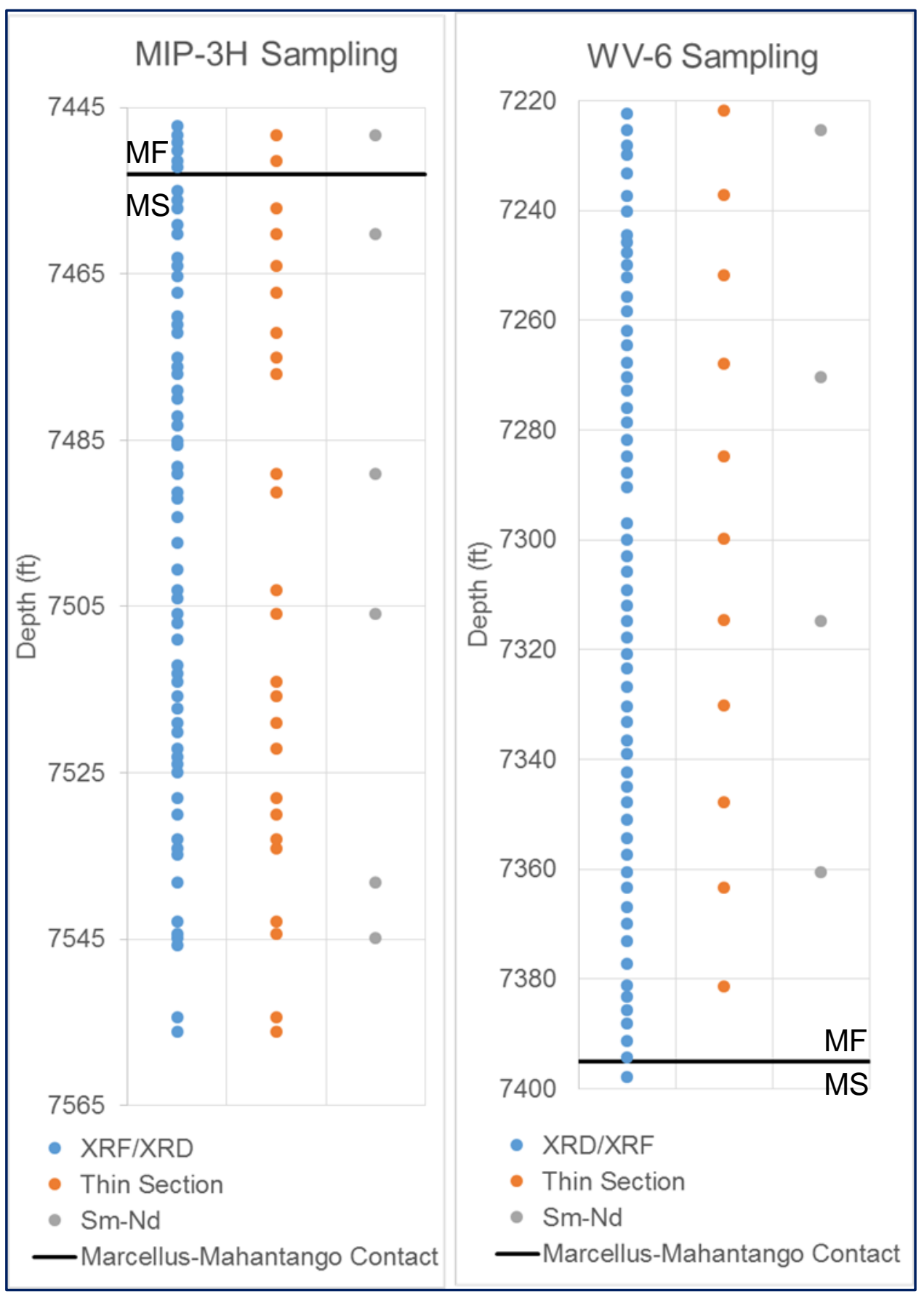

Figure 14. Two graphs showing the sampling distribution for various analyses collected from both the MIP-3H well (left) and the WV-6 well (right). Contacts separating the Marcellus Shale (MS) and Mahantango Formation (MF) are indicated by the black horizontal lines. 


\subsection{Methods}

\subsubsection{Thin-section Petrography}

A total of thirty-six thin sections were made for petrographic analysis to characterize mineralogy and texture of the various petrofacies present throughout the sampled section of the Hamilton Group. Twenty-five thin-sections were made from 1inch diameter sidewall plugs selected from the MIP-3H well. Thin-section sampling was limited to those core plugs which were large enough for thin-sectioning. Eleven standard thin-sections were made from core samples collected from the WV-6 well approximately every 15 feet throughout the Mahantango Formation (Fig 14). All thin-sections were made by National Petrographic Services, Inc. to the standard thickness of 30 microns. Two microscopes were used for thin-section petrography, an Olympus SZX10 (6.3-2000x magnification) and an Olympus BX53 (6.3-63x magnification), in order to view a range of details within each thin-section.

Petrofacies were established from these thin sections and were characterized by differences in color, grain size, grain assemblages, and detrital versus authigenic components. Each sample was given a descriptive name based off of the Picard (1971) classification of fine-grained rocks if it was dominated by clay and larger clasts ( $\geq$ silt). The Milliken (2014) classification system for fine-grained sedimentary rocks was used if the sample was dominated by mud and contained the grain types or components used in this classification. Note that many of the claystones from the Picard (1971) classification could be crossed-classified as tarls within the Milliken (2014) classification scheme. Endmember components within each thin-section were estimated and plotted on the ternary classification diagrams of Picard (1971) and Milliken (2014). Additionally, petrofacies 
interpretations were examined within their stratigraphic context. Thin-section petrofacies from samples of the MIP-3H well were compared to a core log and gamma-ray log established by Paronish (2017).

\subsubsection{X-ray Diffraction Analysis (XRD)}

All 121 samples were analyzed using x-ray diffraction (XRD) in order to determine bulk mineralogy. The samples were ground for approximately 4 to 6 minutes using an A Spex Shatterbox with steel grinding containers until powdered. Powdered samples were pressed into chemplex pellets and analyzed using the PANalytical X'Pert Pro X-ray Diffractometer at West Virginia University Shared Research Facilities. Samples were analyzed at $2 \theta$ angles between $5^{\circ}$ and $75^{\circ}$, with a step time of $\sim 75$ seconds, for a total sample analysis time of approximately 13.5 minutes. $\mathrm{CuK}_{2} \mathrm{x}$-ray beams were concentrated and shot through a $20 \mathrm{~mm}$ brass opening onto an Xcelerator ${ }^{\mathrm{TM}}$ detector. Peaks were identified using the PDF2 reference library as part of the X'pert HighScore Plus Program (Appendix I). Mineral percentages were initially determined semiquantitatively using reference intensity ratios (RIR). RIR interpretations allowed for identification of the mineral suites present, absences of specific minerals, and the relative abundances of different mineral phases (Appendix II and IV). However, the abundances are subject to uncertainties related to the choice of the reference standard.

Mineral assemblage interpretation was then quantified using the XRF elemental data to stoichiometrically constrain phase abundances within the mineral assemblage (Appendix III and V). Based on RIR identification of the mineral suite, the abundance of 
each mineral phase was calculated based on the stoichiometries of the PDF2 reference phases using the following assumptions:

1. All $\mathrm{K}$ is in muscovite/illite.

2. The calculated abundance of muscovite represents combined abundance of illite and muscovite.

3. All Fe is in either pyrite and/or chlorite.

4. All $\mathrm{Na}$ is in albite.

5. Ca is present in calcite, gypsum, and/or dolomite. Distribution of $\mathrm{Ca}$ among calcite and dolomite phases is assumed to be proportional to the XRD mineral peak height ratios from the diffractograms in the Marcellus Shale, where gypsum was absent. A similar approach was used to determine abundances of calcite, gypsum, and dolomite within the Mahantango Formation.

6. $\mathrm{Mg}$ is present in both chlorite and dolomite. Distribution of $\mathrm{Mg}$ among these two phases is assumed to be proportional to the respective peak height ratios.

7. Barite is present as a strontian-barite, which contains both $\mathrm{Ba}$ and $\mathrm{Sr}$, inferred from the XRF results.

8. Si is present in quartz, albite, and muscovite. Quartz concentrations were calculated from the remaining $\mathrm{SiO}_{2}$ after albite and muscovite/illite concentrations were calculated.

9. The sum of crystalline components does not include organic matter and was normalized to $100 \%$.

Mineralogical data was statistically analyzed using PAST 3.0 software in order to identify patterns via Euclidean cluster analysis. 


\subsubsection{X-ray Fluorescence Geochemical Analysis (XRF)}

$\mathrm{X}$-ray fluorescence (XRF) analysis was performed on all 121 samples to establish the abundance of both major and trace elements. Samples were analyzed using a Thermo ARL Perform'X X-ray Fluorescence Spectrometer located at the Hamilton College Analytical Laboratory. Elemental compositions ranging from $\mathrm{C}$ to $\mathrm{U}$ on the periodic table can be detected and are reported as weight percentages of oxides for major elements or as parts per million (ppm) for trace elements. Samples were also powdered in preparation for XRF analysis. The same powders used for XRD analysis of the MIP-3H samples were used for XRF analysis. Samples from the WV-6 well were ground in aluminum ceramic grinding containers at the Hamilton College Analytical Lab in preparation for XRF analysis. A second aliquot of all powders was subjected to serial loss on ignition (LOI) at temperatures of $600^{\circ} \mathrm{C}$ and $900^{\circ} \mathrm{C}$ in order to remove and quantify organic matter and carbonates from the sample. Powders were fused into glass beads prior to XRF analysis (Appendix VI).

Oxide abundances from XRF analysis were converted to moles in order to calculate the chemical index of alteration (CIA; Eq. 1; Nesbitt and Young, 1984; Fedo et al., 1995).

$$
\begin{gathered}
\mathrm{CIA}=\left[\mathrm{Al}_{2} \mathrm{O}_{3} /\left(\mathrm{Al}_{2} \mathrm{O}_{3}+\mathrm{CaO} *+\mathrm{K}_{2} \mathrm{O}+\mathrm{Na}_{2} \mathrm{O}\right)\right] \times 100 \\
\mathrm{CaO}^{*}=\mathrm{mol} \mathrm{CaO}-\operatorname{mol~CO}_{2 c c}-(0.5 \times \mathrm{mol} \mathrm{CO})_{\mathrm{dol}}-\left[(10 / 3) \times \mathrm{mol}_{2} \mathrm{O}_{5}\right]_{\mathrm{ap}} \\
\mathrm{cc}=\text { calcite} ; \text { dol }=\text { dolomite } ; \text { ap = apatite }
\end{gathered}
$$


High CIA values (> 75) are associated with increased chemical weathering, whereas low CIA values $(<\sim 50)$ indicate decreased chemical weathering alteration (Nesbitt and Young, 1984; McLennan et al., 1993; Lee, 2002; Potter et al., 2005).

The chemical index of weathering (CIW) was also calculated using molar concentrations and can be interpreted similarly to CIA trends with respect to weathering. The CIW is a useful way to identify if the calculated CIA weathering trends have been influenced by mobile potassium. Potassium is absent from this equation, so that weathering trends independent of potential K-metasomatism could be identified (Eq. 2; Harnois, 1988).

Eq. 2. $\mathrm{CIW}=\left[\mathrm{Al}_{2} \mathrm{O}_{3} /\left(\mathrm{Al}_{2} \mathrm{O}_{3}+\mathrm{CaO}^{*}+\mathrm{Na}_{2} \mathrm{O}\right)\right] \times 100$

The index of compositional variability (ICV) was calculated using the oxide weight percentages to provide insight into provenance by recognizing enrichment of heavy minerals present (Eq. 3; Cox et al., 1995). The CIA and CIW weathering indices are dependent upon relative abundances of clays versus feldspars, whereas the ICV provides a better index for discriminating geochemical modification of the parent rock lithology by evaluating the abundances of Fe and Mg (Cox et al., 1995; Potter et al., 2005).

Eq. $3 \quad \mathrm{ICV}=\left(\mathrm{CaO}+\mathrm{K}_{2} \mathrm{O}+\mathrm{Na}_{2} \mathrm{O}+\mathrm{Fe}_{2} \mathrm{O}_{3 \text { total }}+\mathrm{MgO}+\mathrm{MnO}+\mathrm{TiO}_{2}\right) / \mathrm{A}_{2} \mathrm{O}_{3}$ 
Decreasing ICV values reflect increasing modification by chemical weathering. Calculating the ICV helps to identify oxide weathering trends influenced by non-clay silicate minerals (Cox et al., 1995; Potter et al., 2005).

In addition, elemental ratios and ternary diagrams were used to evaluate geochemical composition of the rock samples and interpret sediment source composition (Roser and Korsch, 1988; Zhang et al., 1998; Baioumy, 2004; Table 2). Roser and Korsch (1998) determined a technique to identify sediment source composition, independent of grain size, through discriminant function analysis using major element geochemistry. Four discrimination equations were established from their work in order to identify source rock composition independent of biogenic influence (D1 and D2) and for rocks influenced by biogenic sedimentation (D3 and D4). The following equations were used to calculate discrimination factors DF1, DF2, DF3, and DF4 and recognize compositional variation of the source rock, specifically among mafic igneous, intermediate igneous, felsic igneous, and mature quartzose sedimentary rocks (Eq. 4-7):

Eq 4. $\mathrm{DF} 1=-1.773 \mathrm{TiO}_{2}+0.607 \mathrm{Al}_{2} \mathrm{O}_{3}+0.76 \mathrm{Fe}_{2} \mathrm{O}_{3}(\mathrm{t})-1.5 \mathrm{MgO}+0.616 \mathrm{CaO}+$ $0.509 \mathrm{Na}_{2} \mathrm{O}-1.22 \mathrm{~K}_{2} \mathrm{O}-9.09$

Eq 5. $\mathrm{DF} 2=0445 \mathrm{TiO}_{2}+0.07 \mathrm{Al}_{2} \mathrm{O}_{3}-0.25 \mathrm{Fe}_{2} \mathrm{O}_{3}(\mathrm{t})-1.142 \mathrm{MgO}+0.438 \mathrm{CaO}+$ $1.426 \mathrm{~K}_{2} \mathrm{O}-6.861$

Eq 6. $\quad \mathrm{DF} 3=\left[30.638 \mathrm{TiO}_{2}-12.541 \mathrm{Fe}_{2} \mathrm{O}_{3}(\mathrm{t})+7.32 \mathrm{MgO}+12.031 \mathrm{Na}_{2} \mathrm{O}+\right.$ $\left.35.402 \mathrm{~K}_{2} \mathrm{O}\right] / \mathrm{Al}_{2} \mathrm{O}_{3}-6.382$

Eq 7. $\quad \mathrm{DF} 4=\left[56.50 \mathrm{TiO}_{2}-10.879 \mathrm{Fe}_{2} \mathrm{O}_{3}(\mathrm{t})+30.875 \mathrm{MgO}-5.404 \mathrm{Na}_{2} \mathrm{O}+\right.$ $\left.11.112 \mathrm{~K}_{2} \mathrm{O}\right] / \mathrm{Al}_{2} \mathrm{O}_{3}-3.89$ 
Table 2. Geochemical evaluation of provenance and paleoclimate signals.

\begin{tabular}{|c|c|c|}
\hline Weathering Indices & $\begin{array}{l}\text { Proxies for weathering } \\
\text { intensity }\end{array}$ & References \\
\hline $\begin{array}{l}\text { Chemical Index of Alteration } \\
\text { (CIA) }\end{array}$ & $\begin{array}{c}\text { High CIA=greater } \\
\text { weathering }\end{array}$ & $\begin{array}{c}\text { Nesbitt and Young, } \\
1984\end{array}$ \\
\hline $\begin{array}{l}\text { Chemical Index of Weathering } \\
\text { (CIW) }\end{array}$ & $\begin{array}{c}\text { High CIW = greater } \\
\text { weathering }\end{array}$ & Harnois, 1988 \\
\hline $\begin{array}{c}\text { Index of Compositional } \\
\text { Variability (ICV) }\end{array}$ & High ICV = less weathering & Cox et al., 1995 \\
\hline \multicolumn{3}{|l|}{ Ratios } \\
\hline $\mathrm{Si} / \mathrm{Al}$ & $\begin{array}{l}\text { Proxy for clay influence, } \\
\text { lower value=more clay input }\end{array}$ & $\begin{array}{c}\text { McLennan et al., } \\
1993\end{array}$ \\
\hline $\mathrm{Ti} / \mathrm{Al}$ & $\begin{array}{l}\text { Proxy for terrestrial clastic } \\
\text { influence; higher value= } \\
\text { more terrestrial clastic input }\end{array}$ & Murphy et al., 2000 \\
\hline $\mathrm{Th} / \mathrm{Sc}$ and $\mathrm{Th} / \mathrm{U}$ & $\begin{array}{l}\text { Specific ratio ranges are tied } \\
\text { to general terrane types }\end{array}$ & $\begin{array}{l}\text { McLennan et al., } \\
1993\end{array}$ \\
\hline \multicolumn{3}{|l|}{ Cross-plots } \\
\hline $\mathrm{Zr} / \mathrm{Sc}$ vs. Th/Sc & $\begin{array}{l}\text { Identifies signs of sediment } \\
\text { recycling }\end{array}$ & $\begin{array}{c}\text { McLennan et al., } \\
1993\end{array}$ \\
\hline $\mathrm{Th} / \mathrm{Sc}$ vs. $\varepsilon_{\mathrm{Nd}}$ & $\begin{array}{l}\text { Differentiates source terrane } \\
\text { types }\end{array}$ & $\begin{array}{l}\text { McLennan et al., } \\
1993\end{array}$ \\
\hline \multicolumn{3}{|l|}{ Ternary Plots } \\
\hline $\mathrm{Al}_{2} \mathrm{O}_{3}-\left(\mathrm{CaO}+\mathrm{Na}_{2} \mathrm{O}\right)-\mathrm{K}_{2} \mathrm{O}$ & $\begin{array}{l}\text { Both ternaries identify } \\
\text { composition of source }\end{array}$ & $\begin{array}{c}\text { Nesbitt and Young, } \\
1984\end{array}$ \\
\hline $\begin{array}{c}\mathrm{Al}_{2} \mathrm{O}_{3}-\left(\mathrm{CaO}+\mathrm{Na}_{2} \mathrm{O}+\mathrm{K}_{2} \mathrm{O}\right)- \\
(\mathrm{FeO} \text { total } \\
+\mathrm{MgO})\end{array}$ & $\begin{array}{l}\text { material by recognizing } \\
\text { weathering trends }\end{array}$ & $\begin{array}{c}\text { Nesbitt and Young, } \\
1989\end{array}$ \\
\hline La-Th-Sc & Differentiates terrane type & $\begin{array}{c}\text { McLennan et al., } \\
1990\end{array}$ \\
\hline Discrimination Diagrams & $\begin{array}{l}\text { Differentiates source terrane } \\
\text { composition; specifically } \\
\text { between felsic, intermediate, } \\
\text { and mafic igneous, and } \\
\text { quartzose sedimentary } \\
\text { sources }\end{array}$ & $\begin{array}{l}\text { Roser and Korsch, } \\
1988\end{array}$ \\
\hline
\end{tabular}




\subsubsection{Samarium-Neodymium (Sm-Nd) Isotopic Analysis}

$\mathrm{Sm}-\mathrm{Nd}$ isotopic analyses were used to calculate Nd-model ages. Radiogenic isotopes were measured for 10 whole rock samples by ultra-high precision $(<20 \mathrm{ppm})$ thermal ionization mass spectrometry (TIMS) at Geochronex Analytical Services Ltd. Samples taken from the depths of 7448, 7460, 7505, and 7544 feet were sent to Geochronex Analytical Services as 5 g rock chips. These rock chips were powdered, spiked with a ${ }^{149} \mathrm{Sm}_{-}{ }^{150} \mathrm{Nd}$ solution, and dissolved in a mixture of $\mathrm{HF}, \mathrm{HNO}_{3}$, and $\mathrm{HClO}_{4}$. The rare earth elements were separated via conventional cation-exchange techniques, with Sm and Nd further separated by extraction chromatography on HDEHP covered Teflon powder. A second set of samples consisting of $10 \mathrm{~g}$ were collected from depths of $7225,7270,7314,7360,7489$, and 7538 feet were powdered in a jasper mortar.

Following powdering, samples were spiked with a ${ }^{149} \mathrm{Sm}^{-150} \mathrm{Nd}$ trace solution. The mixture then decomposed in a $\mathrm{Hf}+\mathrm{HNO}_{3}(3: 1)$ solution at $140^{\circ} \mathrm{C}$ for 2 days, followed by baking in $\mathrm{HNO}_{3}$ at $250^{\circ} \mathrm{C}$ for 2 hours within a Milestone Ultra Clave high pressure microwave oven. Separation of Sm and Nd was done through two-stage ion exchange and extraction chromatography (Richard et al., 1976; Pin and Zalduegui, 1997). Isotope abundance measurements were done using a ThermoFisher Triton TI mass spectrometer.

Depleted mantle $\left(\tau_{\mathrm{DM}}\right)$ model ages were calculated from $\mathrm{Sm}-\mathrm{Nd}$ isotopic analysis results (Eq. 8; Dickin, 1995; DePaolo, 1998). Additionally, measured ${ }^{143} \mathrm{Nd} /{ }^{144} \mathrm{Nd}$ ratios can be compared to bulk-earth ratios of the chondritic uniform reservoir (CHUR). This ratio comparison is the $\varepsilon_{\mathrm{Nd}}$ notation (Eq. 9; DePaolo and Wasserburg, 1976). ${ }^{143} \mathrm{Nd} /{ }^{144} \mathrm{Nd}$ evolved through radioactive decay of original ${ }^{147} \mathrm{Sm}$ and ${ }^{146} \mathrm{Sm}$ to ${ }^{143} \mathrm{Nd}$ and ${ }^{142} \mathrm{Nd}$, 
respectively at a constant decay rate. The $\varepsilon_{\mathrm{Nd}}$ notation describes this evolution of the sample with respect to the original chondritic reservoir at any point specific point in time:

Eq. 8 .

$$
\begin{gathered}
\tau_{D M}=\frac{1}{\lambda} \ln \left(\frac{{ }^{143} N d l^{144} N d_{\text {sam }}-{ }^{143} N d l^{144} N d_{D M}}{{ }^{147} S m l^{144} N d_{\text {sam }}-{ }^{147} S m l^{144} N d_{D M}}+1\right) \\
\varepsilon_{\mathrm{Nd}}=\left[\frac{\left({ }^{143} \mathrm{Nd} /{ }^{144} \mathrm{Nd}\right)_{\text {sample }}-\left({ }^{143} \mathrm{Nd} /{ }^{144} \mathrm{Nd}\right)_{\mathrm{CHUR}}}{\left(143 \mathrm{Nd} /{ }^{144} \mathrm{Nd}\right)_{\mathrm{CHUR}}}\right] \times 10000
\end{gathered}
$$

Eq. 9.

where ${ }^{143} \mathrm{Nd} /{ }^{144} \mathrm{Nd} d_{\mathrm{DM}}=0.51315,{ }^{147} \mathrm{Sm} /{ }^{144} \mathrm{Nd}_{\mathrm{DM}}=0.2137,{ }^{143} \mathrm{Nd} /{ }^{144} \mathrm{Nd} \mathrm{CHUR}_{\mathrm{R}}=0.512638$, and ${ }^{147}$ Sm decay constant $(\lambda)=6.54 * 10^{-12}($ Dickin, 1995$)$. 


\section{RESULTS}

\subsection{Petrographic Results}

Petrographic analysis of thirty-six thin-sections from the two wells led to the differentiation of four primary petrofacies end members that characterize the heterogeneity of lithofacies throughout the sampled section (Fig. 15-22; Appendix VII).

\subsubsection{Petrofacies 1: Tarly claystone}

The rocks of the tarly claystone petrofacies appear light brown to darkish brown in color and contain grains ranging from clay-size to silt-size (Fig. 19). The matrix of this petrofacies is dominated by detrital clays, specifically illite and muscovite (Fig. 19A). These matrix components show strong alignment horizontal to bedding as indicated by their anisotropy. Silt-sized grains include authigenic euhedral pyrite crystals (Fig. 19FG), detrital quartz grains, and detrital micas. Intrabasinal grains include clay pellets or peloids (Fig. 19B), agglutinated foraminifera (Fig. 19C), radiolarians, and tasmantid algae (Fig. 19E). Large grains of woody organic matter and black organic stringers are present within the matrix (Fig. 19D). Planar laminations are visible at low magnification and can be identified by transitions in color, from dark brown to light brown. Thin fractures also run parallel to the linear fabric of the rock. These rocks have been classified as tarly claystones due to their abundant clay-rich matrix. This petrofacies is most common within the Mahantango Formation and upper Marcellus Shale. 


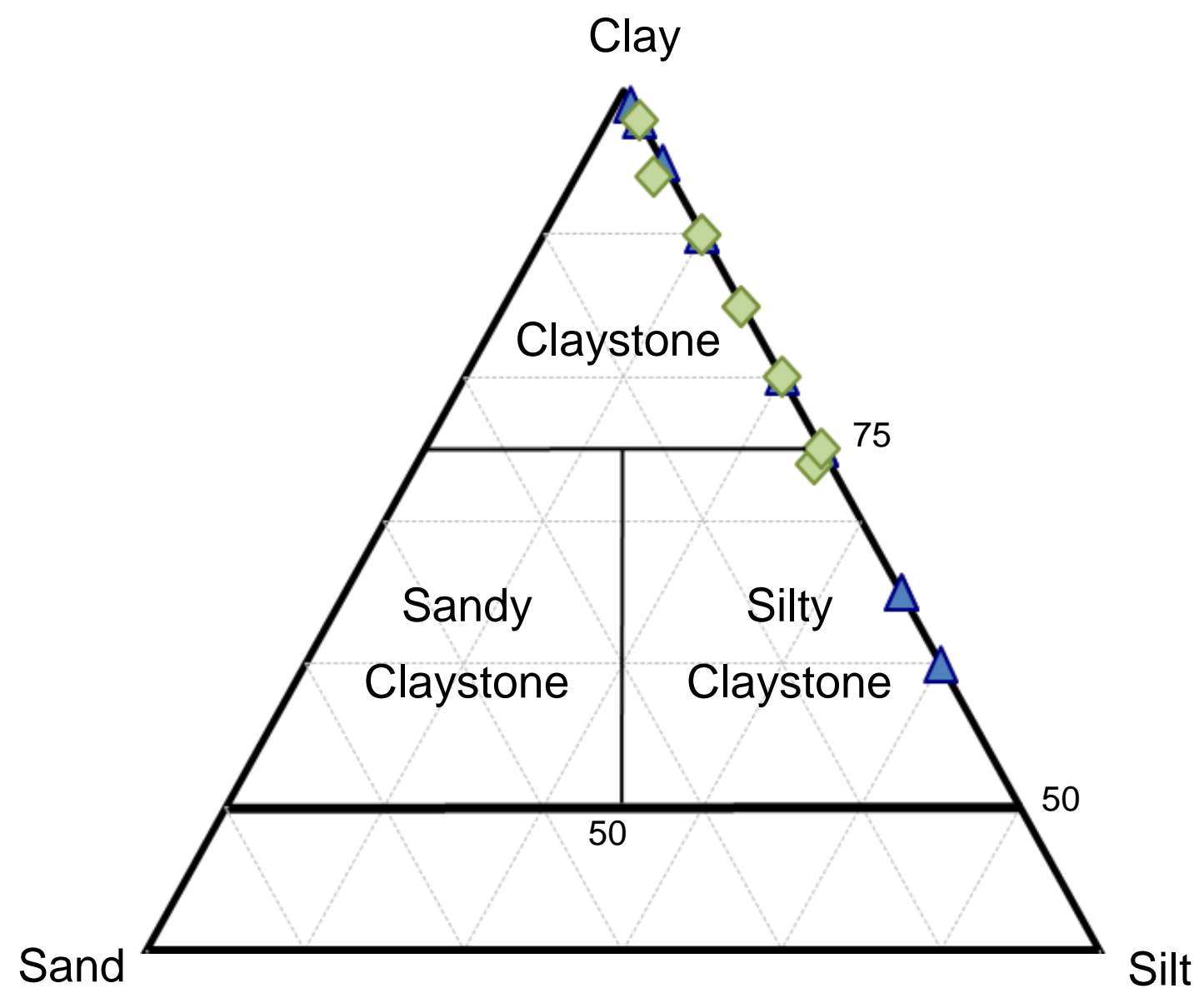

Figure 15. Ternary diagram showing the uppermost triangle of the Picard (1971) classification of fine-grained rocks and sediments with twenty samples plotting within this classification scheme. Eleven of the samples were from the Marcellus Shale (blue triangles) and nine from the Mahantango Formation (green diamonds). Of these thin-sections, seven (2 MF, 5 MS) fell within the silty claystone field and thirteen (7 MF, $7 \mathrm{MS}$ ) falll within the claystone field. 


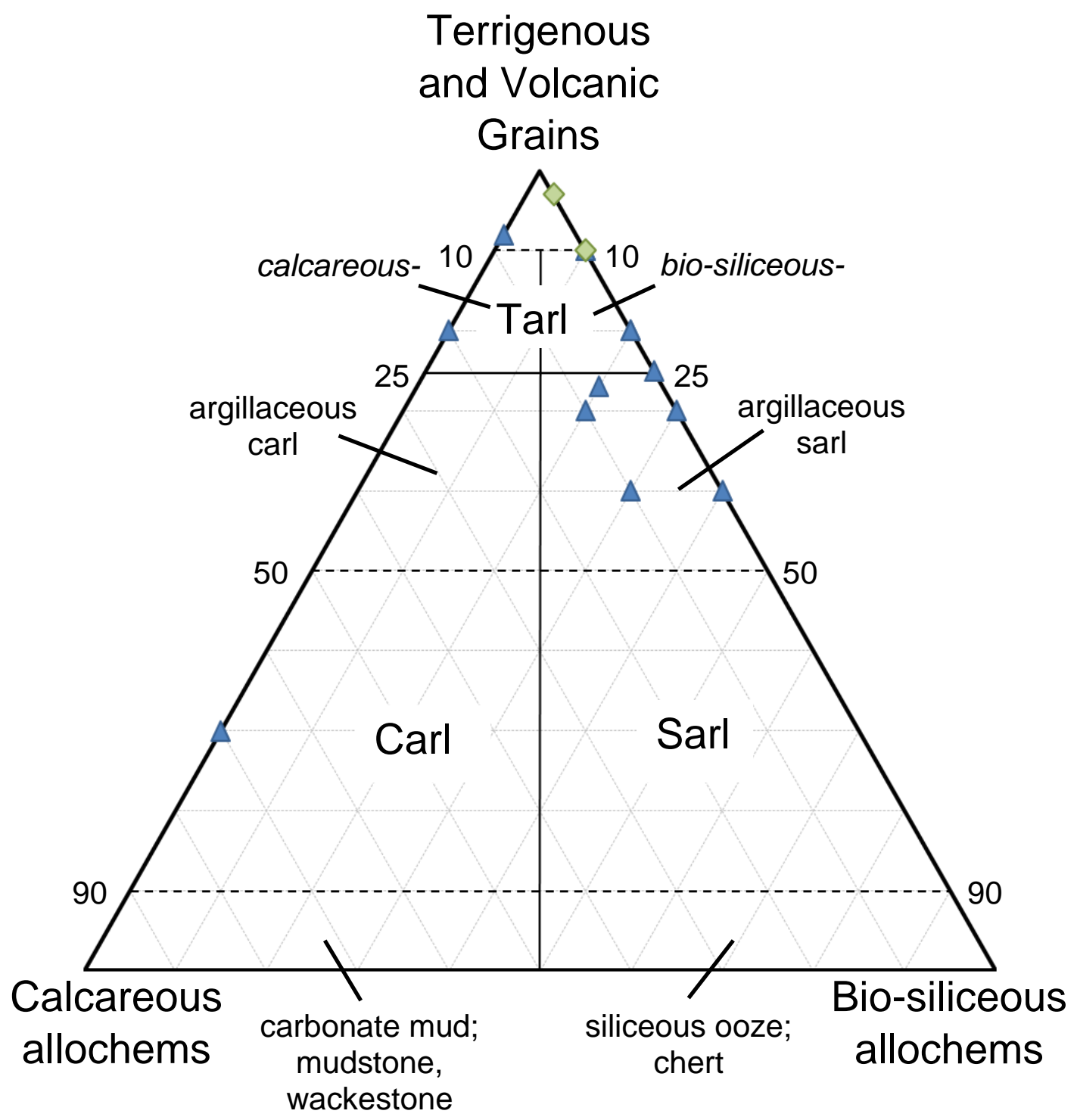

Figure 16. Ternary diagram showing the Milliken (2014) classification for fine grained sedimentary rocks. Fifteen samples plotted within this classification scheme with two samples from the Mahantango Formation (green diamonds) and thirteen from the Marcellus Shale (blue triangles). 


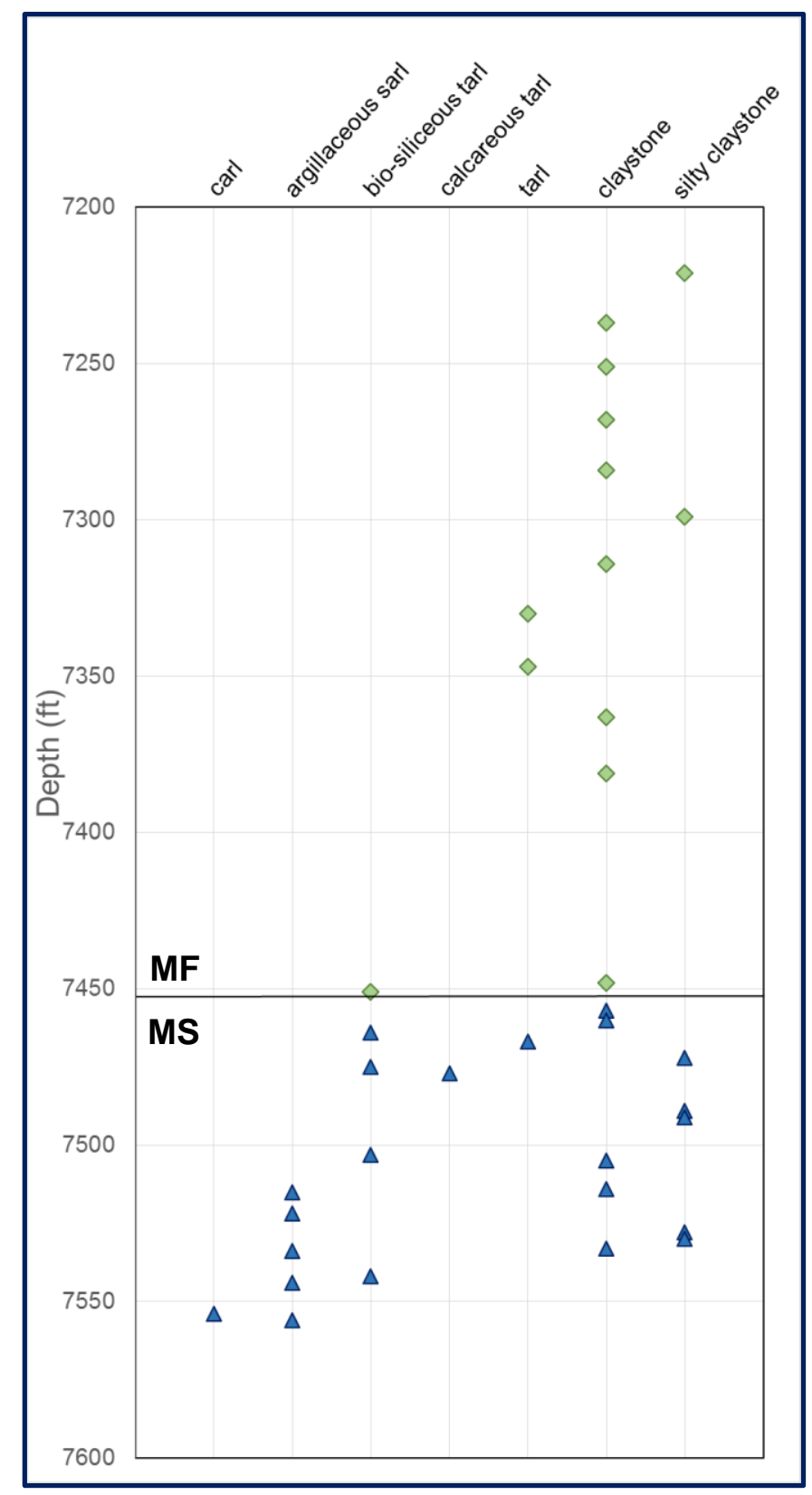

Figure 17. Stratigraphic context of petrographic analysis of all thirty-six thin-sections throughout the Mahantango Formation (MF; green diamonds) and Marcellus Shale (MS; blue triangles). The Marcellus-Mahantango contact within the MIP-3H well is indicated by the horizontal line. 


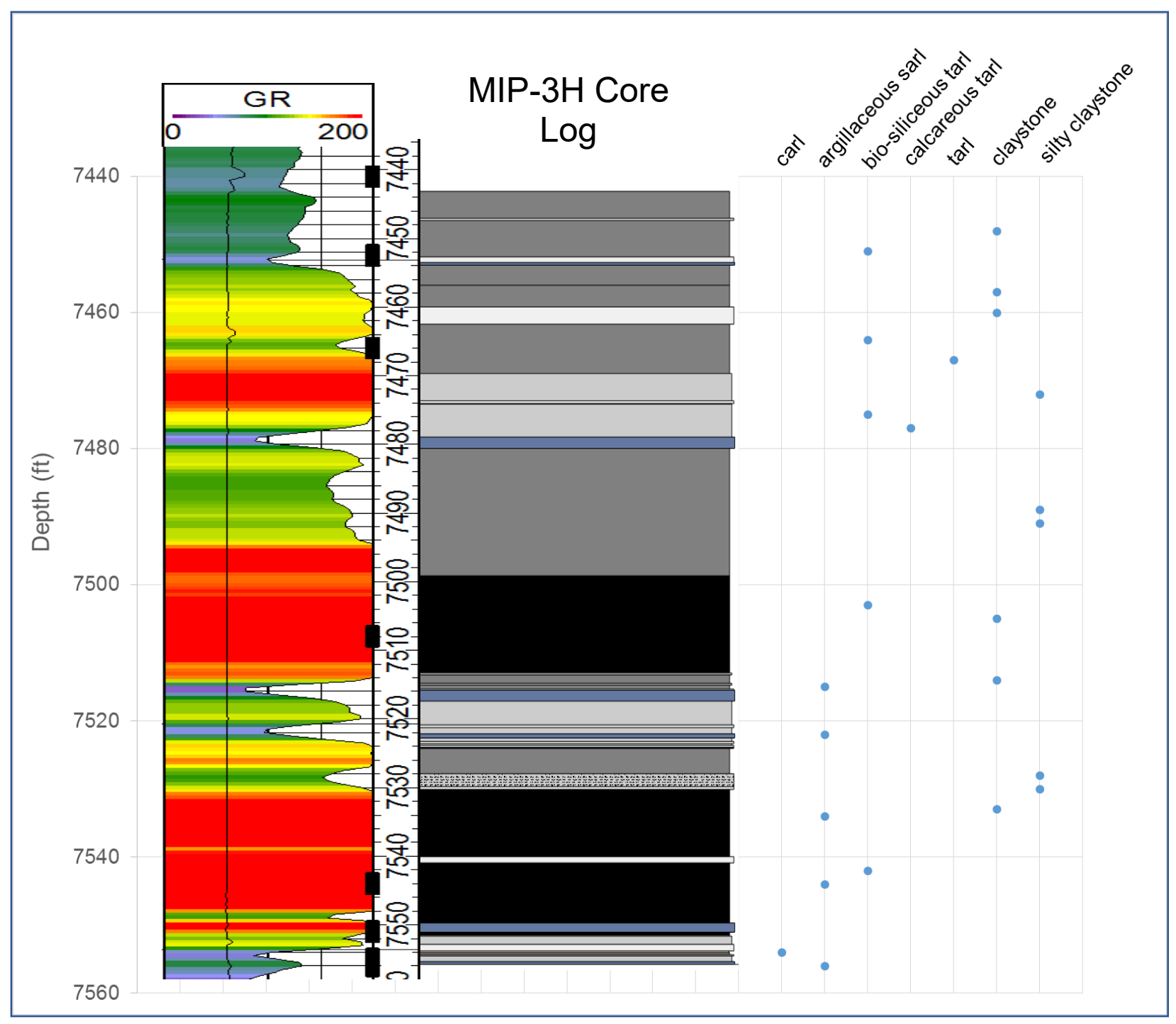

Dark Gray Shale

Mixed Shale

Calcareous shale

Black shale

Wackestone/Calcareous shale

K-Bentonite

Dark Gray Shale with

Calcareous Nodules

Figure 18. Comparison of petrofacies identification of the MIP-3H samples in comparison to the core log and gamma-ray log prepared by Paronish (2017). Note how the argillaceous sarls and bio-siliceous tarls correlate strongly with the presence of black shale and high gamma-ray values. 


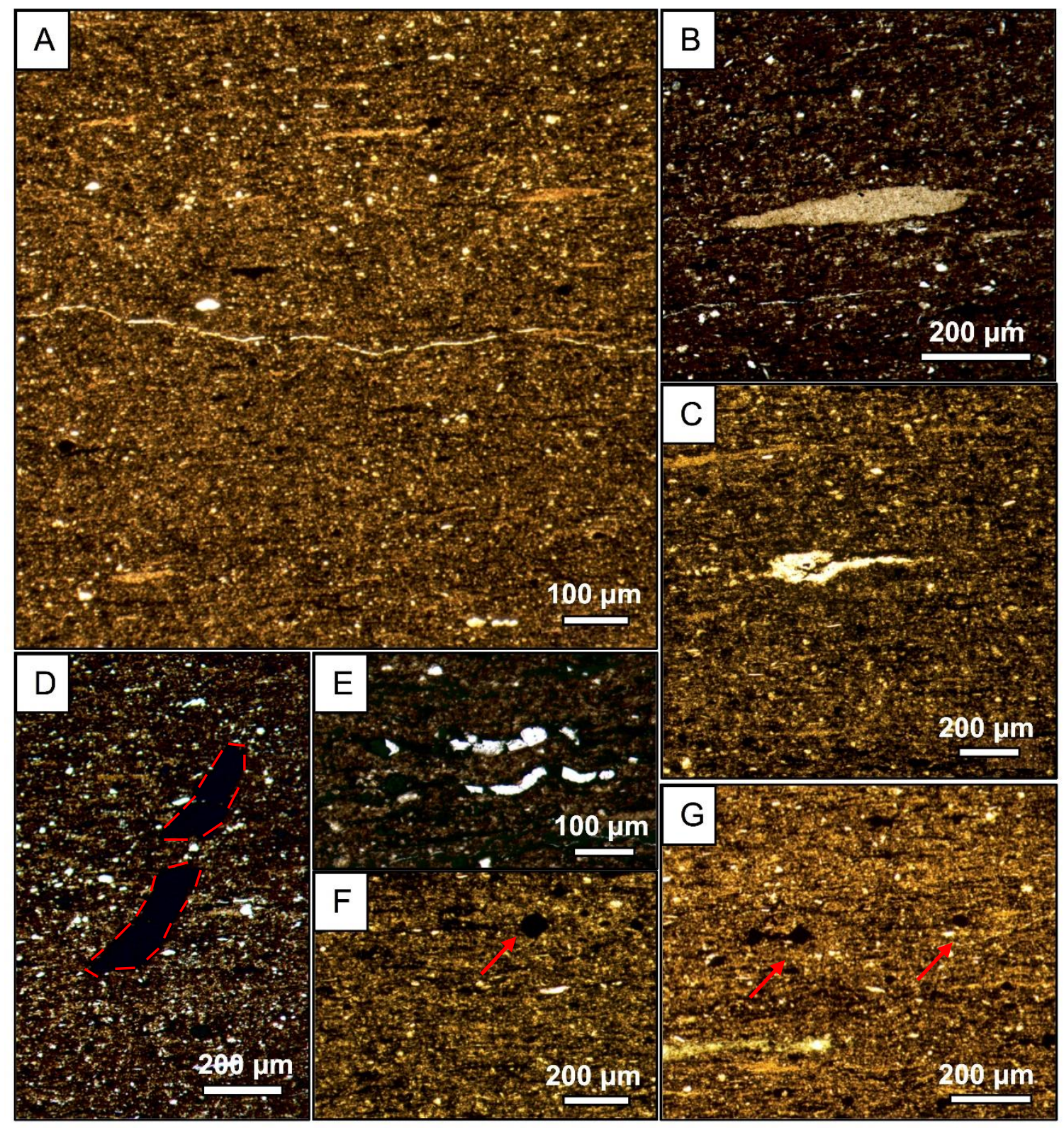

Figure 19. Thin section images from MIP-3H 7448 in the lower Mahantango Formation showing the tarly claystone petrofacies to demonstrate diversity of the grain assemblage. A: Larger scale view of the petrofacies; B: Clay pellet; C: Agglutinated foraminifera; D: Woody organic matter allochem (red); E: Tasmantid algae; F and G: Euhedral pyrite crystals (red arrows). Images A, C, F, and G were all taken in both transmitted and reflected light, whereas images $\mathrm{B}, \mathrm{D}$, and $\mathrm{E}$ were all taken in only transmitted light. 


\subsubsection{Petrofacies 2: Organic-rich argillaceous sarl}

This petrofacies is characteristically black to dark brown in color (Fig. 20). The matrix is primarily composed of illite and organic matter. Larger, silt-size grains are dominated by compressed/collapsed radiolarians composed of microcrystalline silica (Fig. 20B-E). Radiolarians are found abundantly throughout these sarls and show preferential alignment with the horizontal plane along the long axis of their ovoid tests. In some cases, radiolarians also show euhedral pyrite crystals making up part of their in-fill cement (Fig. 20E). Larger authigenic quartz crystal cements can be found, as well as infill or replacement of moldic porosity (Fig. 20F). In reflected light, pyrite framboids are abundant throughout this petrofacies. Laminations are delineated by radiolarian-rich layers (Fig. 20A). Planar fractures are also common within this petrofacies. Due to the abundance of silicified radiolarians and organic-rich matrix, this petrofacies is described as an organic-rich, argillaceous sarl. This petrofacies is most commonly found within the lower Marcellus Shale (Fig. 17-18). 


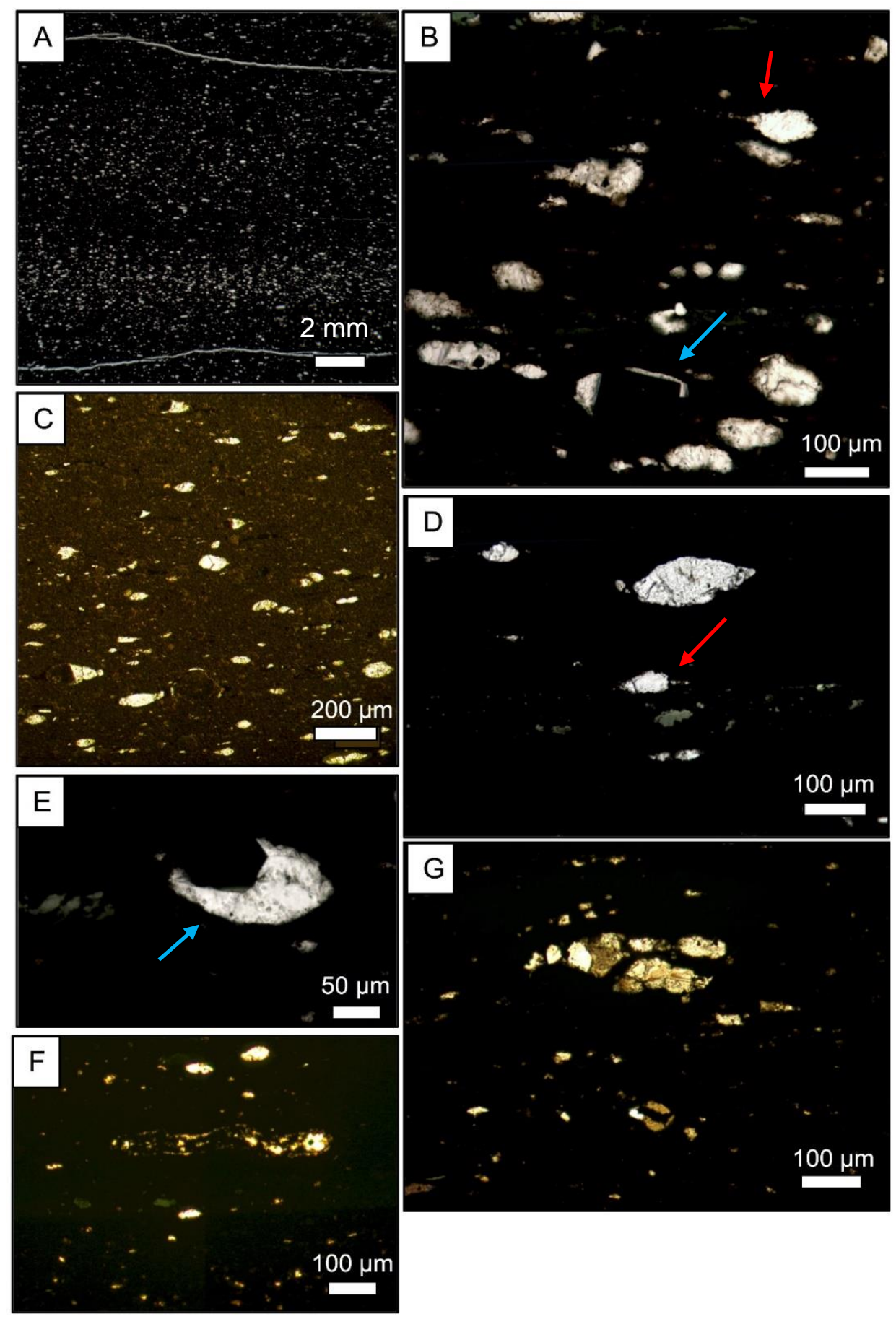

Figure 20. Images of the organic-rich argillaceous sarl petrofacies. A: Laminations formed from intrabasinal; B: Image of compressed radiolarians. Some radiolarians have spins preserved (red arrows) while others have pyritic infill (blue arrows); C: Image of clay- and organic-dominated matrix (brown) with many microcrystalline silica-rich radiolarians (white grains); D: Compressed radiolarian with spin preserved; E: Radiolarian with euhedral pyrite infill. F: Image of moldic porosity infill, potential of tasmantid algae. G: Polycrystalline authigenic quartz cement. All images except for $\mathrm{C}$ and $\mathrm{G}$ were taken in transmitted light. Image $\mathrm{C}$ was taken in both reflected and transmitted light. Image $\mathrm{G}$ was taken in cross-polarized light. Images were taken from the MIP-3H 7544 sample from the lower, organic-rich stratigraphic region of the Marcellus Shale. 


\subsubsection{Petrofacies 3: Styliolinid Carl}

Only one of the thirty-six thin-sections are classified within the styliolinid carl petrofacies (Fig. 21). However, this sample exhibited similar XRD-derived mineralogical composition as lithologies in the middle to lower Marcellus Shale, suggesting that this thin-section may represent a petrofacies that is sparsely interbedded within the Marcellus Shale and not a single anomaly.

The styliolinid carl petrofacies is named from its abundance of styliolinid fossils and clay-calcite matrix. These rocks appear dark brown to gray in color and contain clay to medium sand-sized grains (Fig. 21). The matrix is composed of clay and displacive calcite. The bulk of grains are dominated by styliolinids and thin-walled mollusc shells. Calcite cements are found in much of the intragranular and shelter porosity as well as fractures. However, fossilized shells do not exhibit evidence of recrystallization. Fossils display both drusy and blocky cement within the larger intragranular pores. 

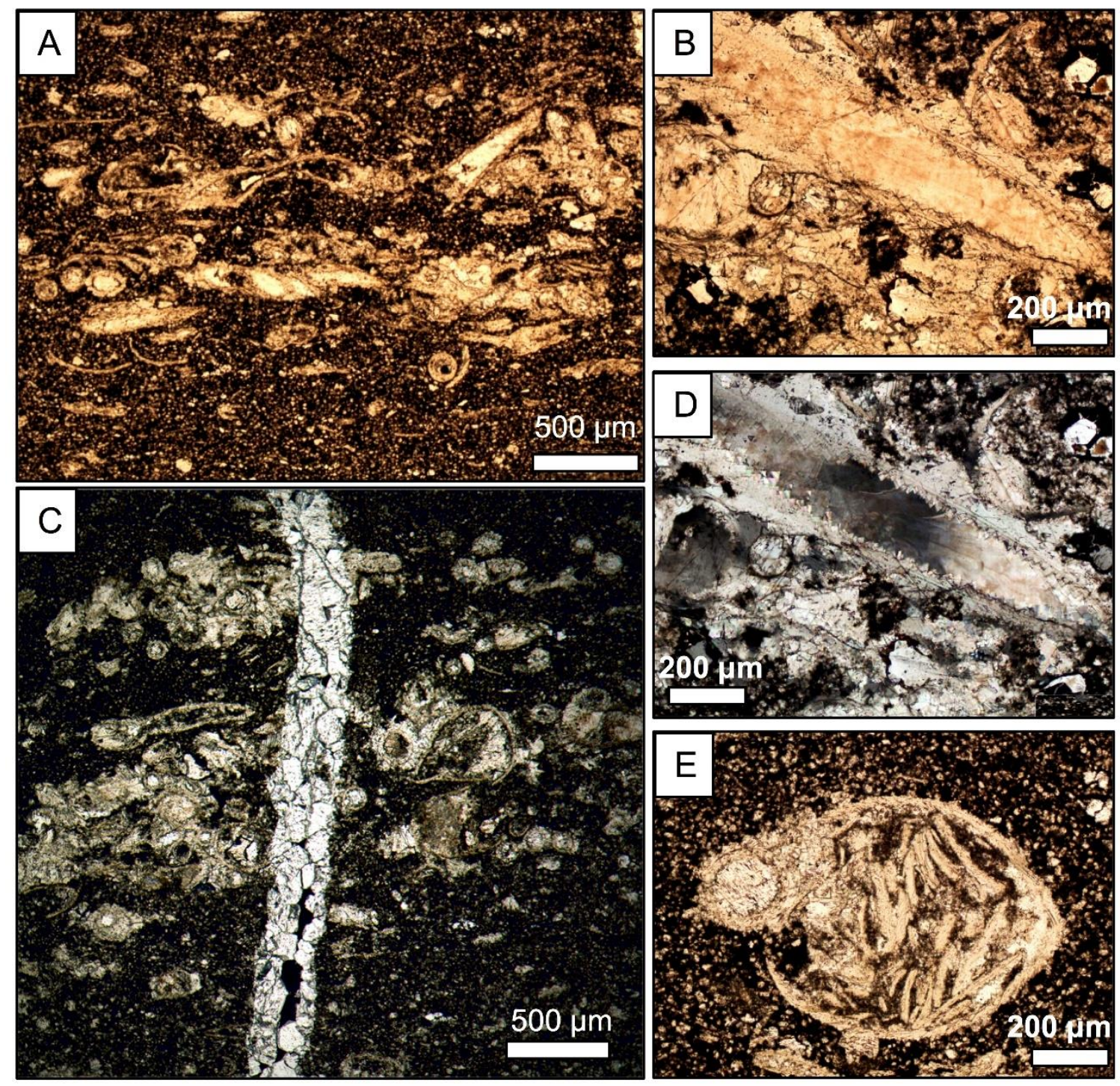

Figure 21. Thin-section images of the styliolinid carl petrofacies from sample MIP-3H 7554 of the lower Marcellus Shale. A: Large scale image of whole-rock fabric; B: Styliolinid cut along the long-axis showing several generations of calcite cementer. Image is in transmitted light; C: Large blocky calcite-filled fracture runs perpendicular to orientation of fossiliferous grains; D: Same view as image B in cross-polarized light; E: A thin-walled mollusc (larger circle) and crosssection of a styliolinid (small, calcite filled circle). All images in plane-polarized light, except for $\mathrm{D}$, which was taken in cross-polarized light. 


\subsubsection{Petrofacies 4: Silty Tarly Claystone}

This petrofacies is found throughout the Mahantango Formation and differs from the tarly claystone by having a higher proportion of extrabasinal sediment absent from the Marcellus Shale. The silty tarly claystone is light to dark brown and consists of a clay-dominated matrix, primarily illite (Fig. 22). Detrital quartz silt is the dominant grain type throughout these rocks (Fig. 22D-E). The quartz silt grains are angular and often define the laminations within these rocks. Organic matter is also a common grain type, often appearing as fine silt-sized grains that partially define the darker brown laminations (Fig. 22C). This petrofacies is classified as a silty tarly claystone because of the claydominated matrix and abundant detrital quartz silt content. 

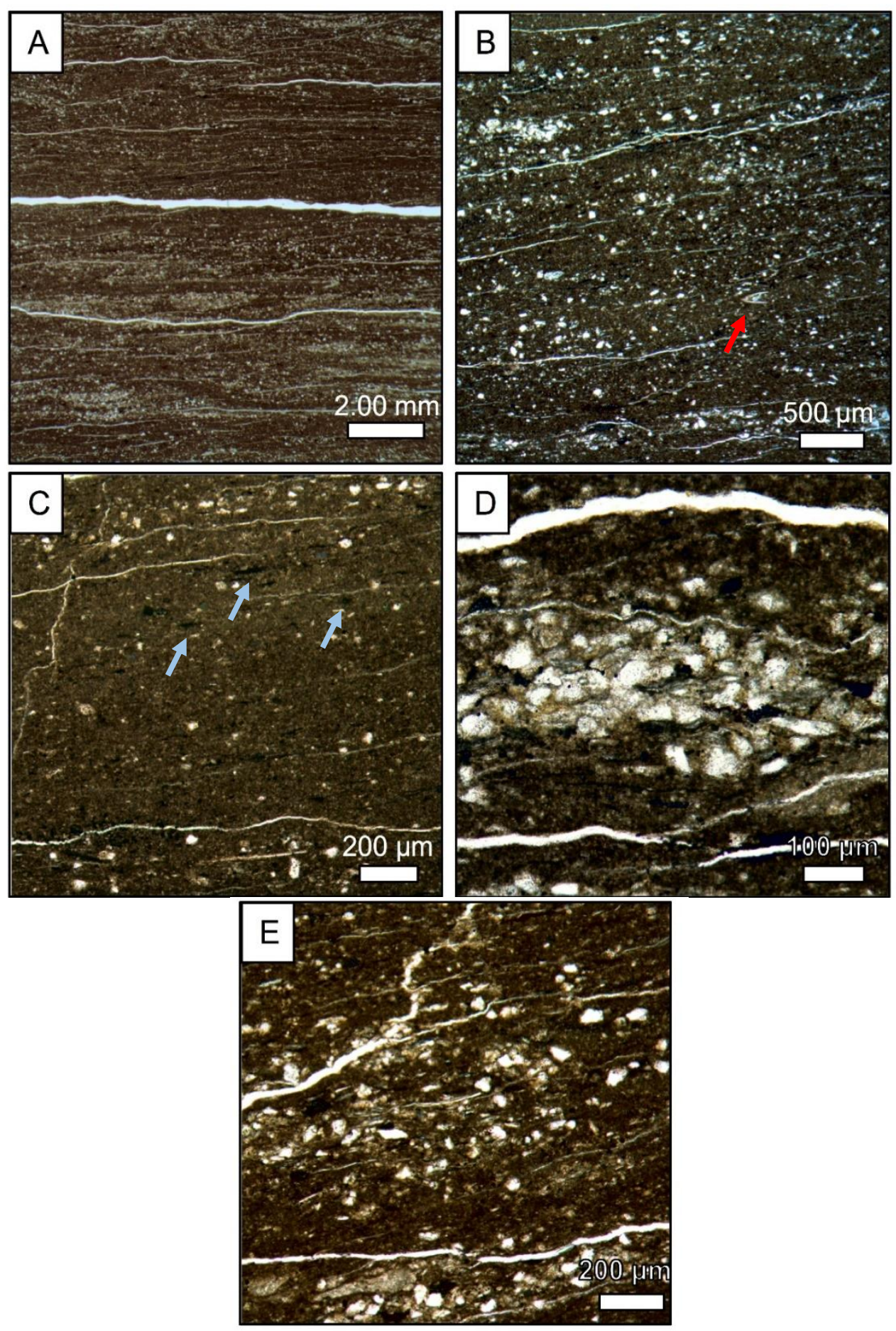

Figure 22. Images of the silty tarly claystone petrofacies. A: Silt-rich versus organic-rich laminations show and distinguished by light brown versus darker brown layers; B: Closer view of silty areas and fossil (?) present (red arrow); C: Image showing grains of organic matter (blue arrows); D and E: Angular detrital quartz silt-rich areas. All images were taken of the WV-6 7221 sample of the Mahantango Formation and are in plane-polarized light. I 


\subsection{Geochemical Results}

\subsubsection{X-ray Diffraction Results}

X-ray diffraction analysis of the MIP-3H samples indicate a mineral suite of up to nine minerals including quartz, illite, muscovite, chlorite, pyrite, albite, calcite, dolomite, and barite (Fig. 23, Appendices II-V). Illite and muscovite were interpreted as one mineral via initial RIR interpretations due to difficulty in peak discrimination. Mineralogical trends show that quartz, illite+muscovite, and albite covary and are inversely correlated with calcite and dolomite (Fig 24). Of the Mg-bearing minerals, chlorite dominates the upper part of the sampled section, whereas dolomite dominates the lower part of the sampled section, with a thin interval between 7488-7500 feet in which both minerals are present in the middle of the sampled section. The barite found within the MIP-3H well is interpreted as a strontian-barite, as both $\mathrm{Sr}$ and $\mathrm{Ba}$ are elevated and strongly correlate within the XRF data (Fig 24C).

Euclidean cluster analysis of all 62 samples revealed seven different distinct clusters (Fig. 25). Each cluster either represents a stratigraphic region of the sampled section (i.e. lower Mahantango Fm.-upper Marcellus Sh.) or samples that were enriched in an anomalous mineral phase (i.e. calcite or barite). Cluster analysis has shown that the upper (> $7497 \mathrm{ft}$.$) , middle ( 7503 \mathrm{ft} .-7514 \mathrm{ft}$.$) , and lower (<7515 ft.) Marcellus Shale all$ have mineralogically distinct facies, with the primary difference being a slight decrease in calcite content up-section. The greatest mineralogical heterogeneity is found within the lower Marcellus Shale stratigraphic interval. 


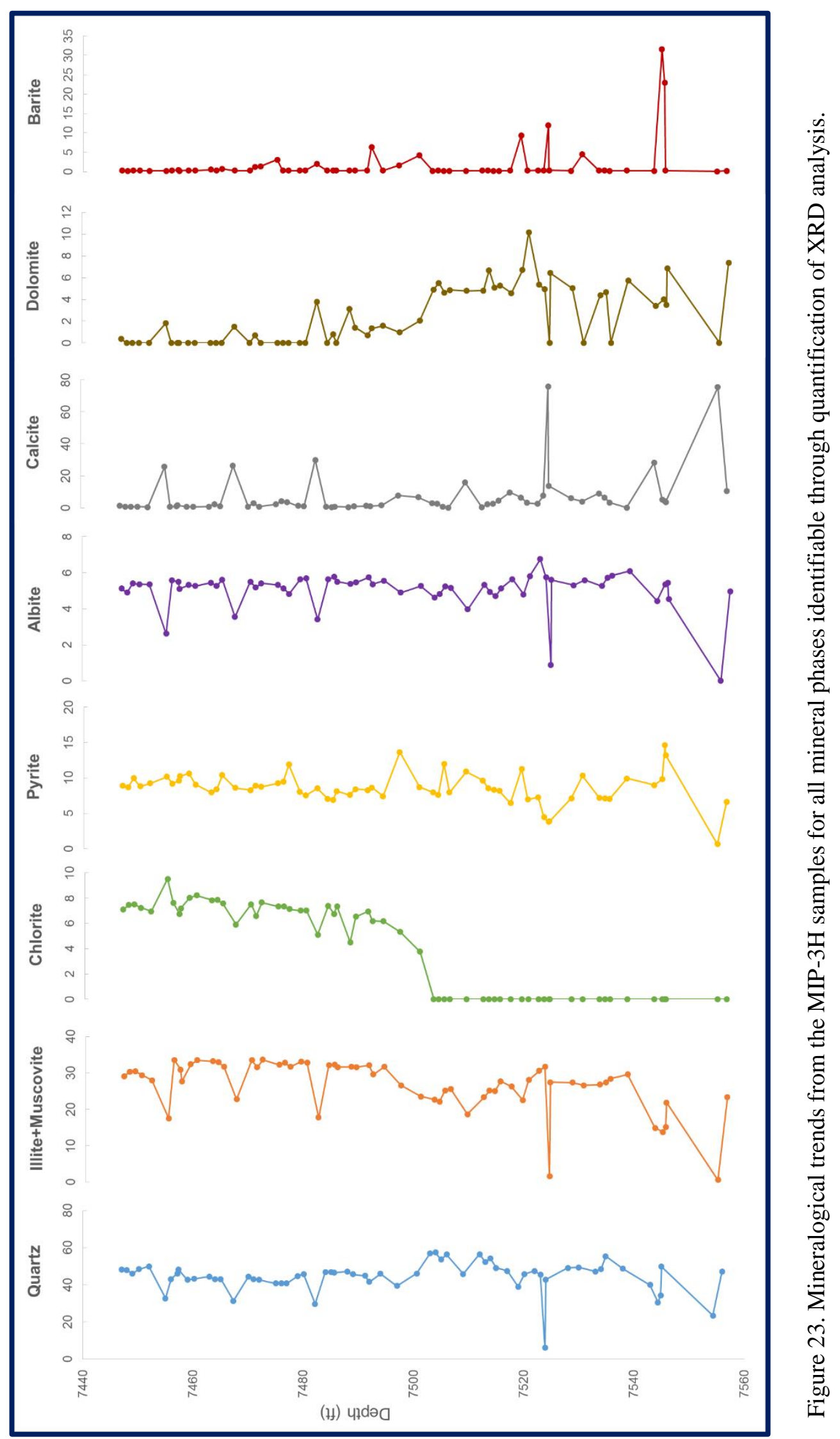




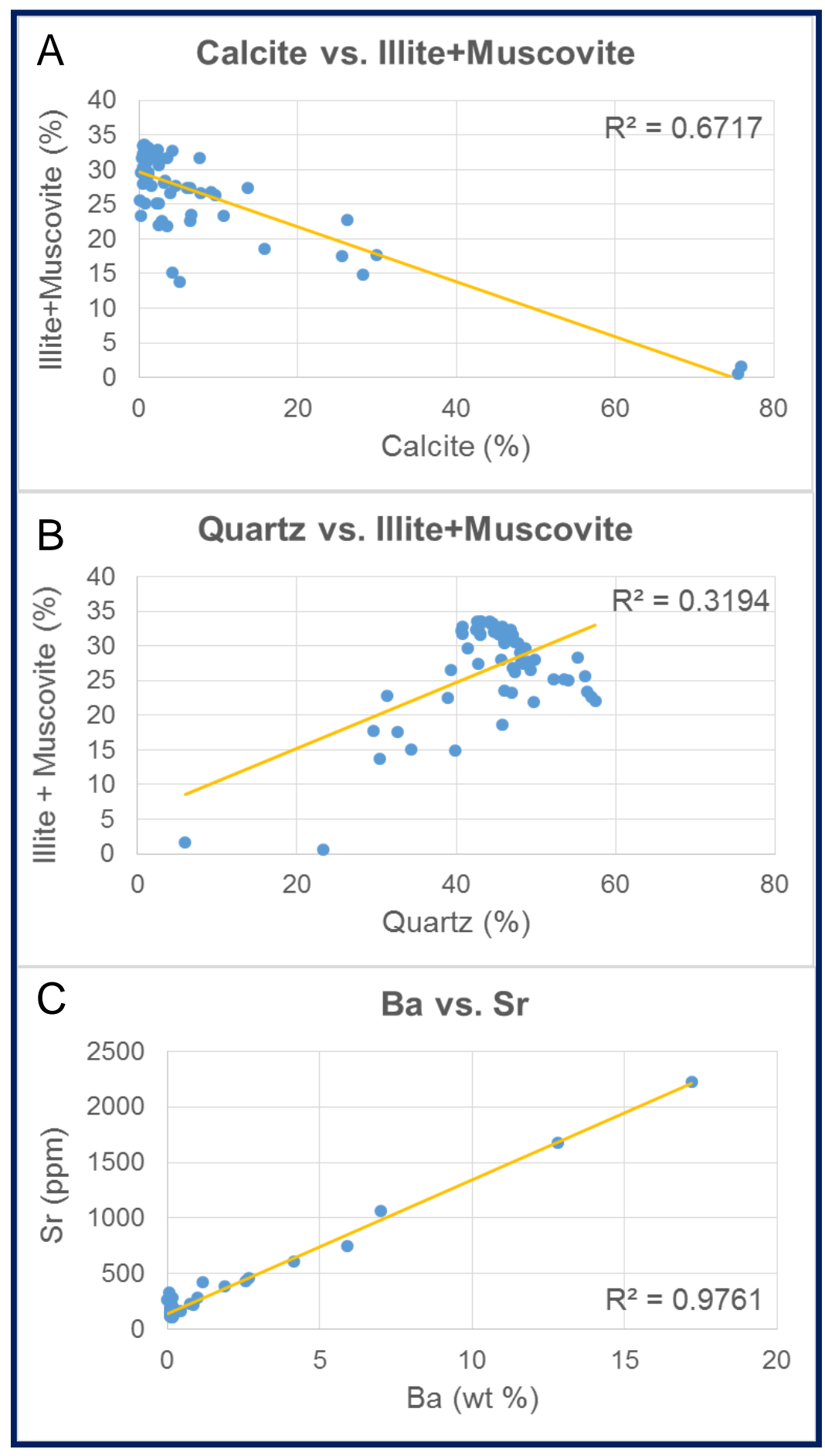

Figure 24. A: Cross-plot of calcite vs. illite+muscovite showing a strong negative correlation. B: Cross-plot of quartz vs. illite+muscovite showing a positive correlation. C: Ba vs. Sr showing a very strong correlation supporting the interpretation that barite within the sampled section is $\mathrm{Sr}$ barite. 


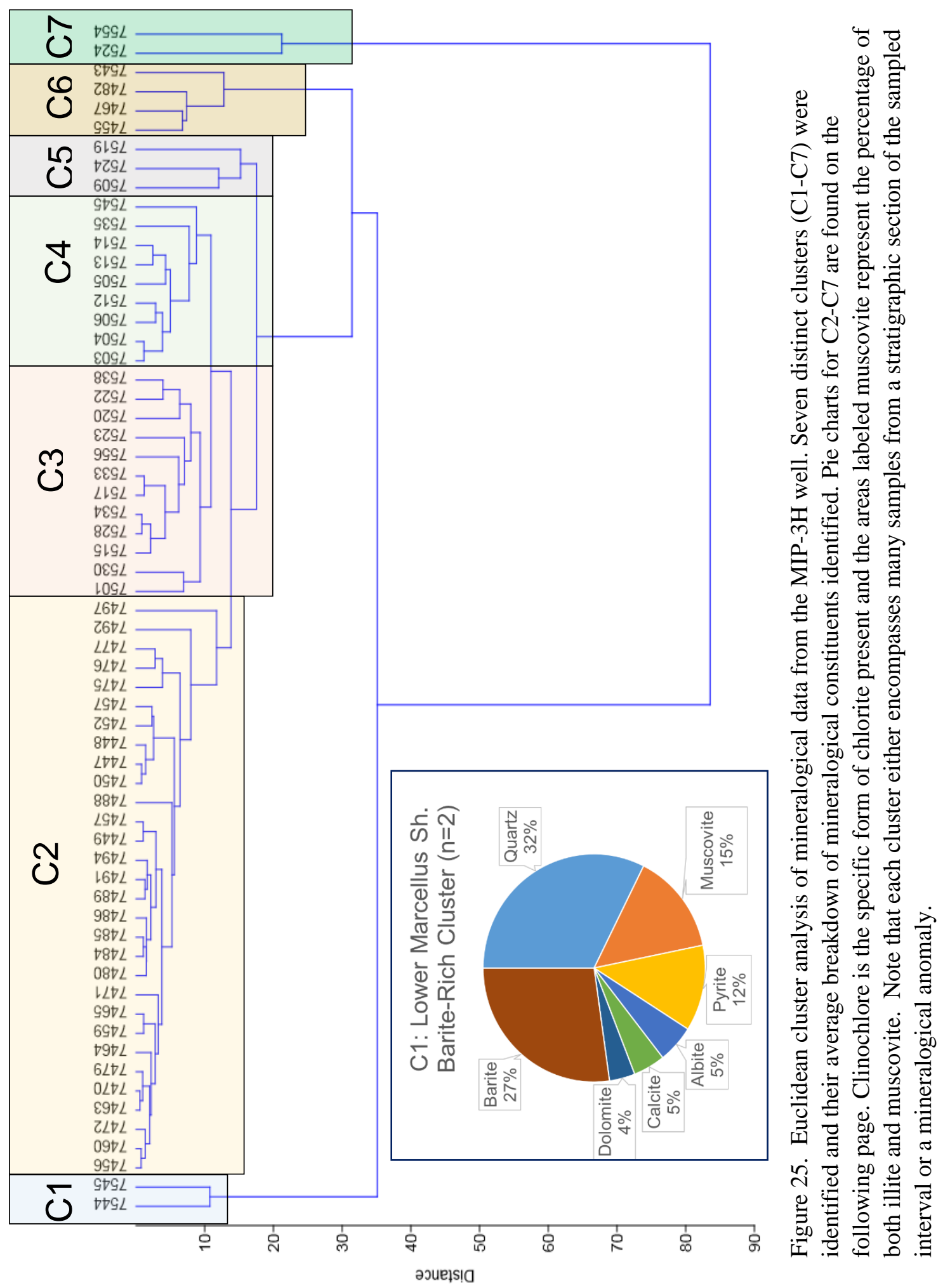



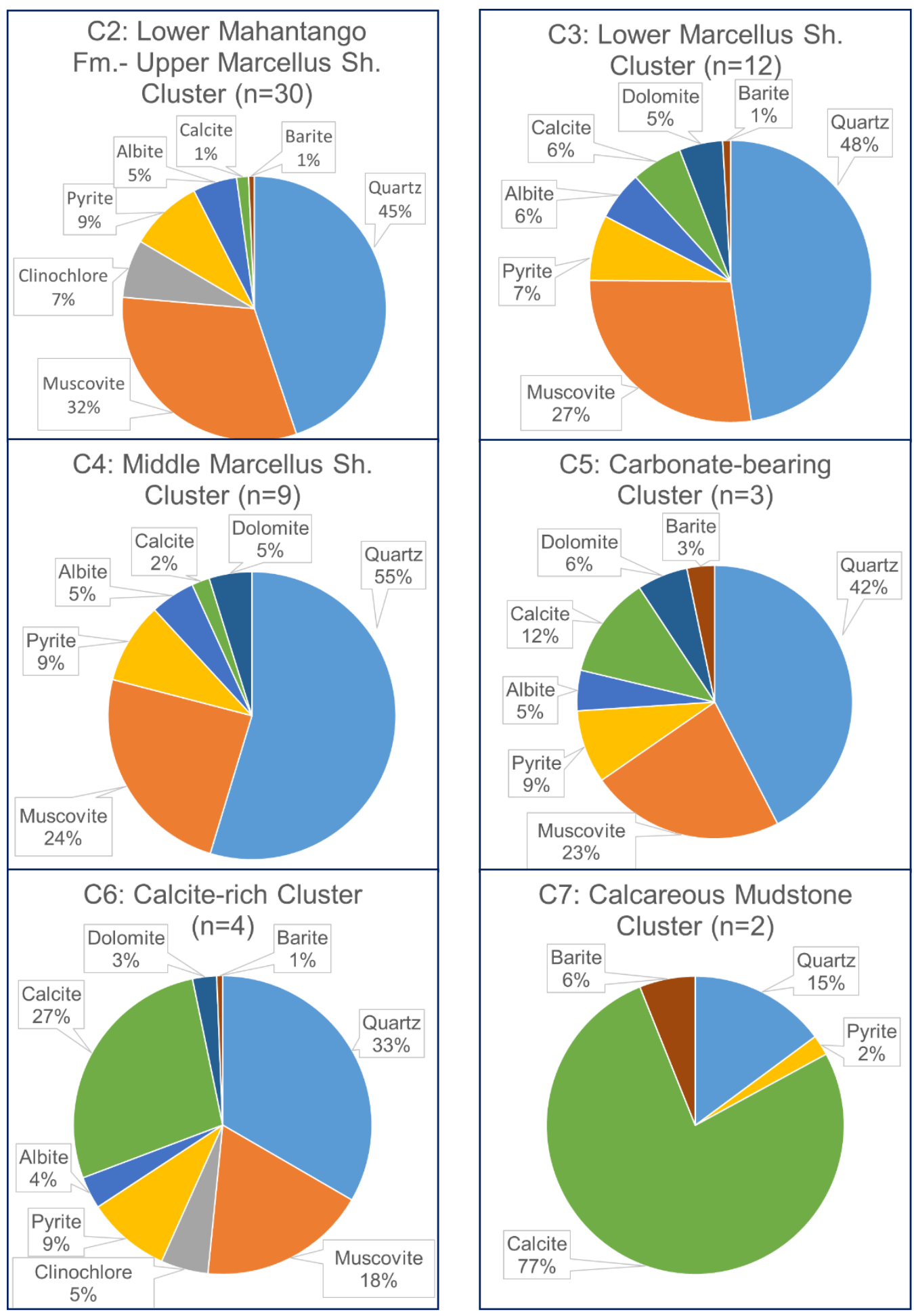

Figure 25. continued. 
X-ray diffraction analysis of the WV-6 samples identified the same nine mineral phases as found within the Marcellus Shale, with the addition of gypsum (Fig. 26). Quartz, muscovite, illite, and chlorite are the dominant mineral phases throughout the Mahantango Formation and displayed similar trends. The minor mineral phase albite commonly followed the trends of the dominant mineral phases. Calcite and dolomite are less abundant in the Mahantango Formation than in the Marcellus Shale. However, gypsum appeared consistently throughout the sampled section ranging from $~ 0.5-6.5 \%$. Chlorite is the only mineral that displayed a consistent increase up-section.

Euclidean cluster analysis of the WV-6 samples revealed five clusters composed of 56 of the samples, with three outliers (Fig. 27). The three outliers were all enriched in a specific mineral phase, drastically increasing their Euclidean distance from the other samples. These phases included calcite (66.43\% at $7354.4 \mathrm{ft}$.$) , pyrite (13.39\% at 7388.1$ ft.), and quartz (50.25\% at $7360.5 \mathrm{ft}$.). Of the five clusters identified, two clusters represent stratigraphic sections of the Mahantango Formation (i.e. Cluster $2=$ middle to upper Mahantango Fm. and Cluster 5=lower Mahantango Formation.) The middle-upper Mahantango Formation differs from the lower Mahantango Formation by exhibiting slight enrichments in clay minerals and gypsum and decreases in quartz up-section. The remaining three clusters identify groups that are rich in carbonates and gypsum, poor in carbonates, or represent an intermediate between the mineralogical facies of the middleupper Mahantango Formation and the lower Mahantango Formation. In all clusters except for $\mathrm{C} 3$ (carbonate-poor cluster), mineralogical averages yielded minimum calcite, dolomite, barite, and gypsum percentages of at least $0.18 \%$. 


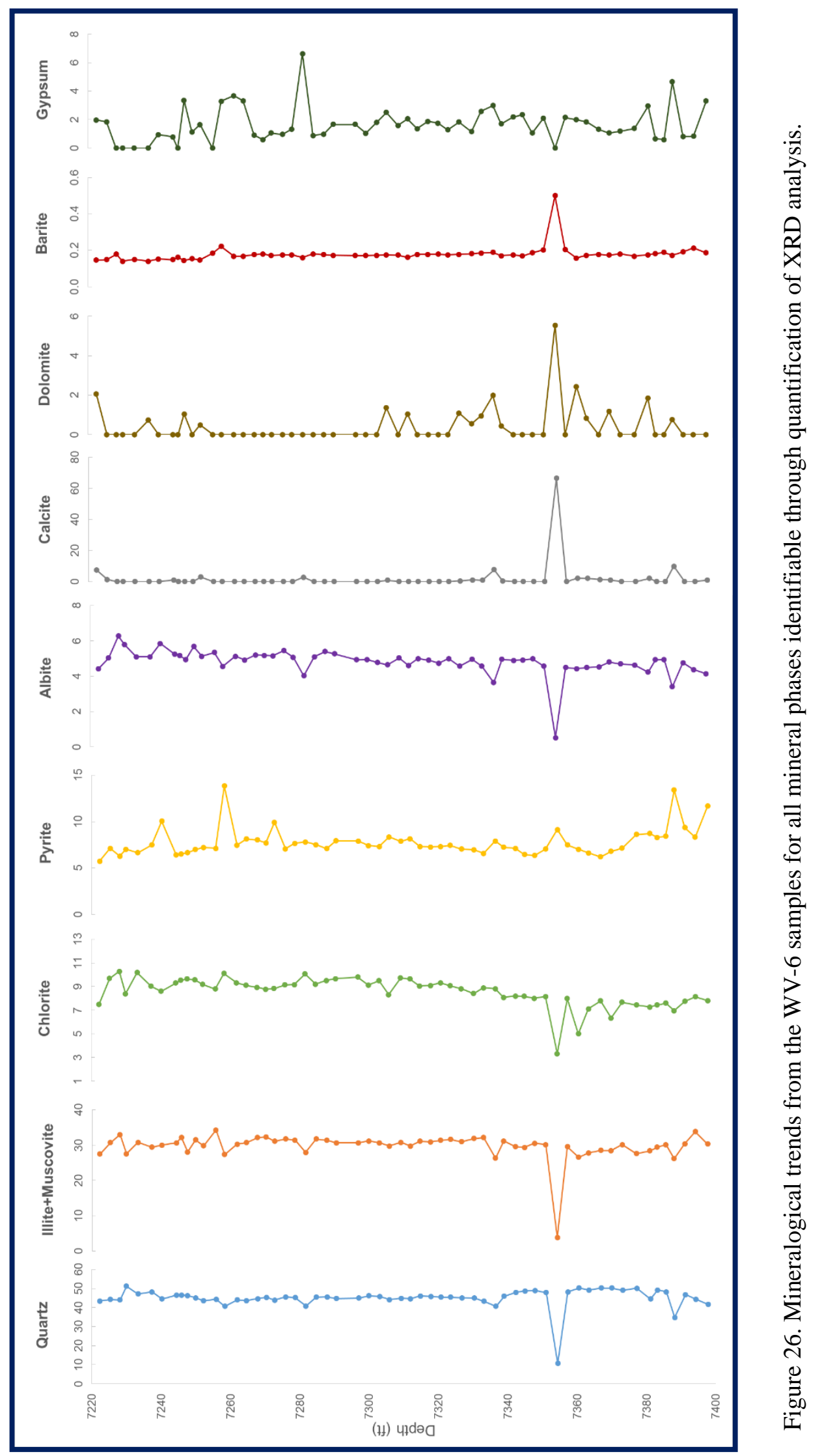




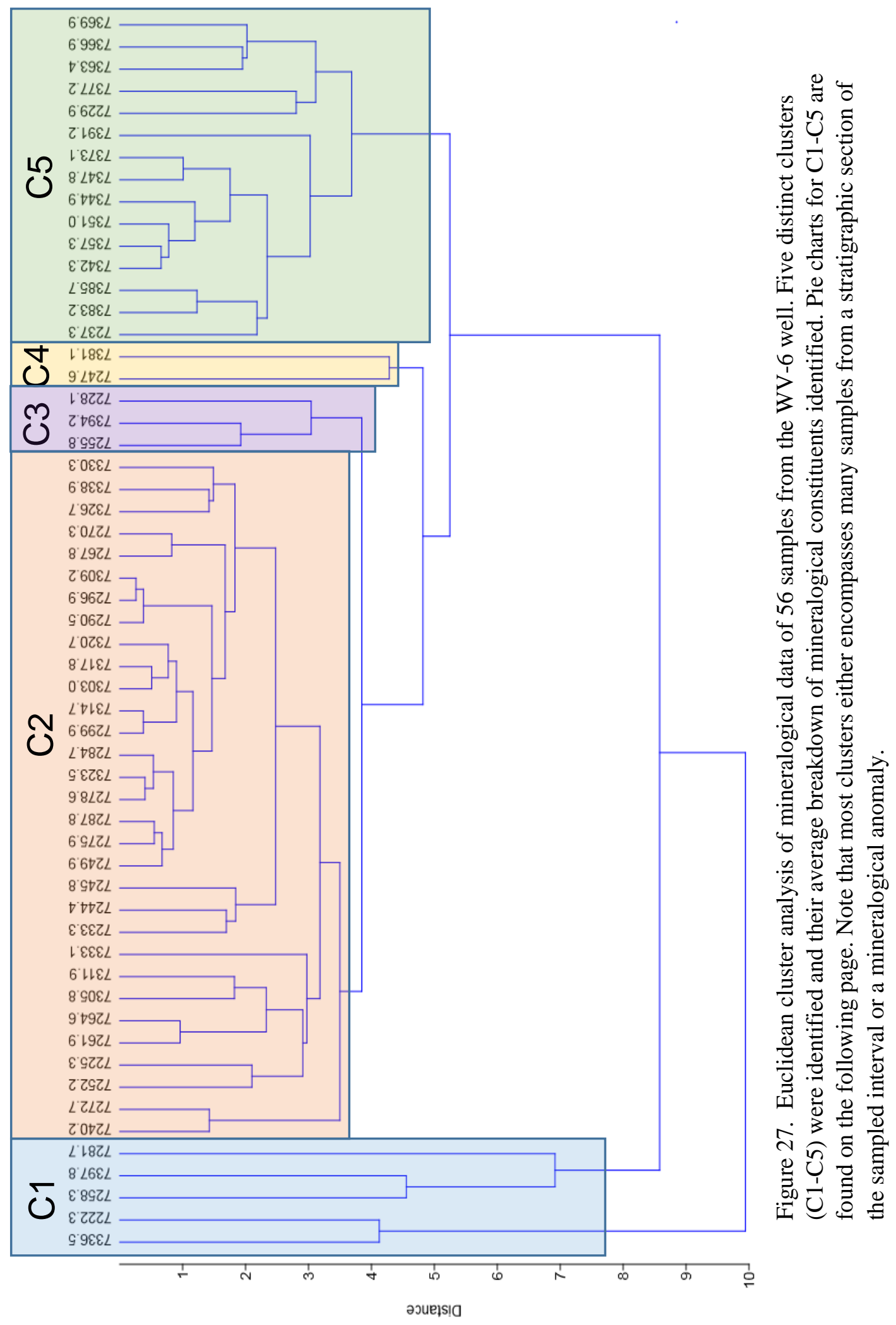




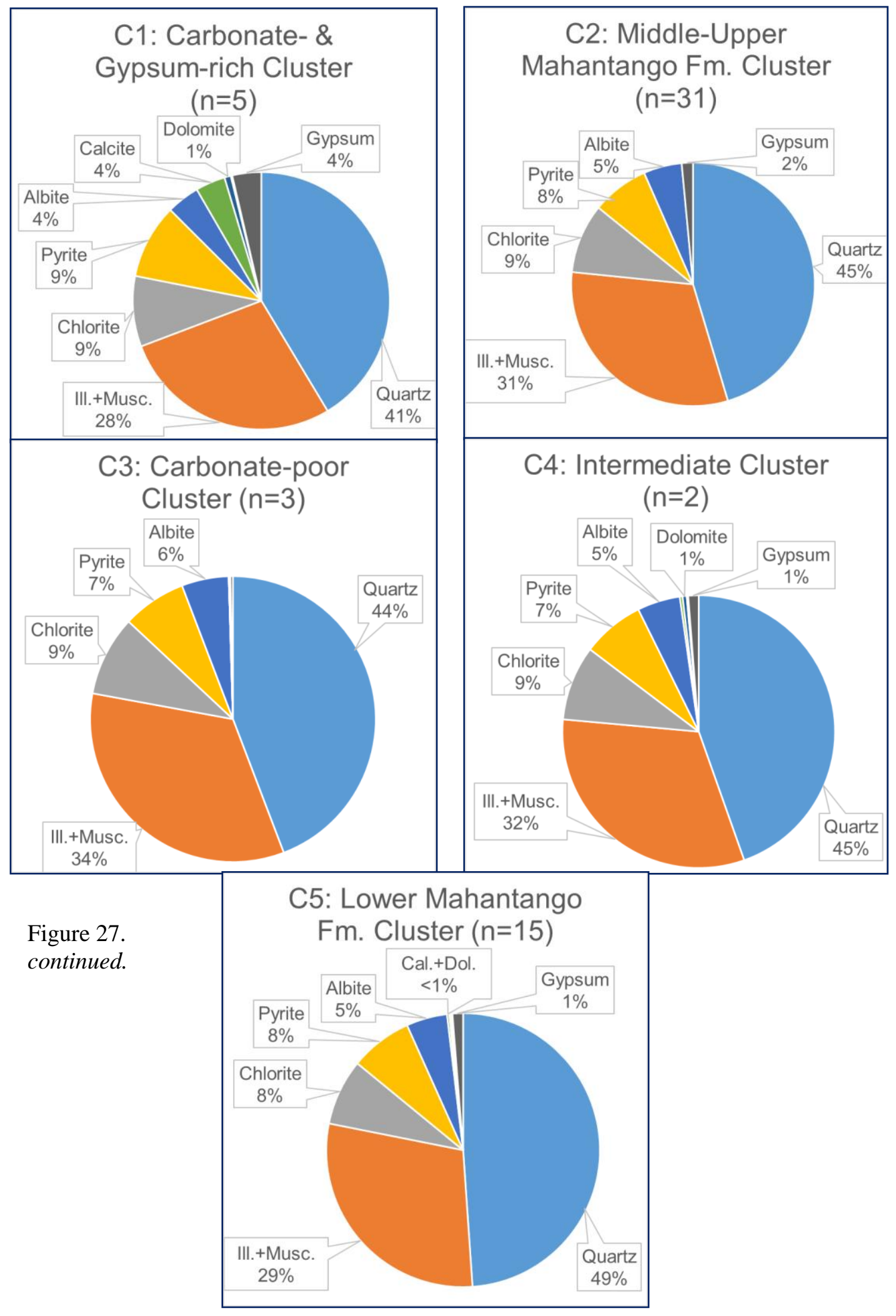




\subsubsection{X-ray Fluorescence Results}

Elemental composition data was collected from both the MIP-3H and WV-6 wells in order to establish a high-resolution chemostratigraphic record of the Marcellus Shale $(n=57)$ and the Mahantango Formation $(n=64)$. Major and trace elements for each suite of samples were determined by XRF (Appendices VIII-XIII). Major element trends were examined as proxies for sediment influx. Si/Al ratios within the Marcellus Shale showed a distinct increase up-section. Ti/Al ratios show a fluctuating cyclic pattern (Fig 28). Within the Mahantango Formation, elemental trends are less clear. Si/Al ratio increases to $\sim 3.9$ within the lower and upper portions of the formation, but are fairly uniform at $\sim 3.0$ throughout the middle section of the unit (Fig. 28).

$\mathrm{Si} / \mathrm{Al}$ and $\mathrm{Ti} / \mathrm{Al}$ from the Marcellus Shale were examined in comparison to TOC $\log$ data in order to further evaluate the relationship between organic content and clay or clastic influx to the basin (Fig. 29A-B). A cross-plot of TOC vs. Ti/Al showed no evidence of correlation $\left(\mathrm{R}^{2}=0.0007\right)$. However, a cross-plot of TOC vs. Si/Al shows a positive correlation $\left(\mathrm{R}^{2}=0.4477\right)$ indicating that increased clay sedimentation to the basin is correlated to lower total organic content values.

Cross-plots of other major elements as well as $\mathrm{Zr}$ were compared to TOC in attempt to identify potential relationships with content of organic matter (Fig. 30). TOC was compared to both $\mathrm{P}_{2} \mathrm{O}_{5}$ and $\mathrm{FeO}$ to evaluate the effects of limiting nutrient input on 


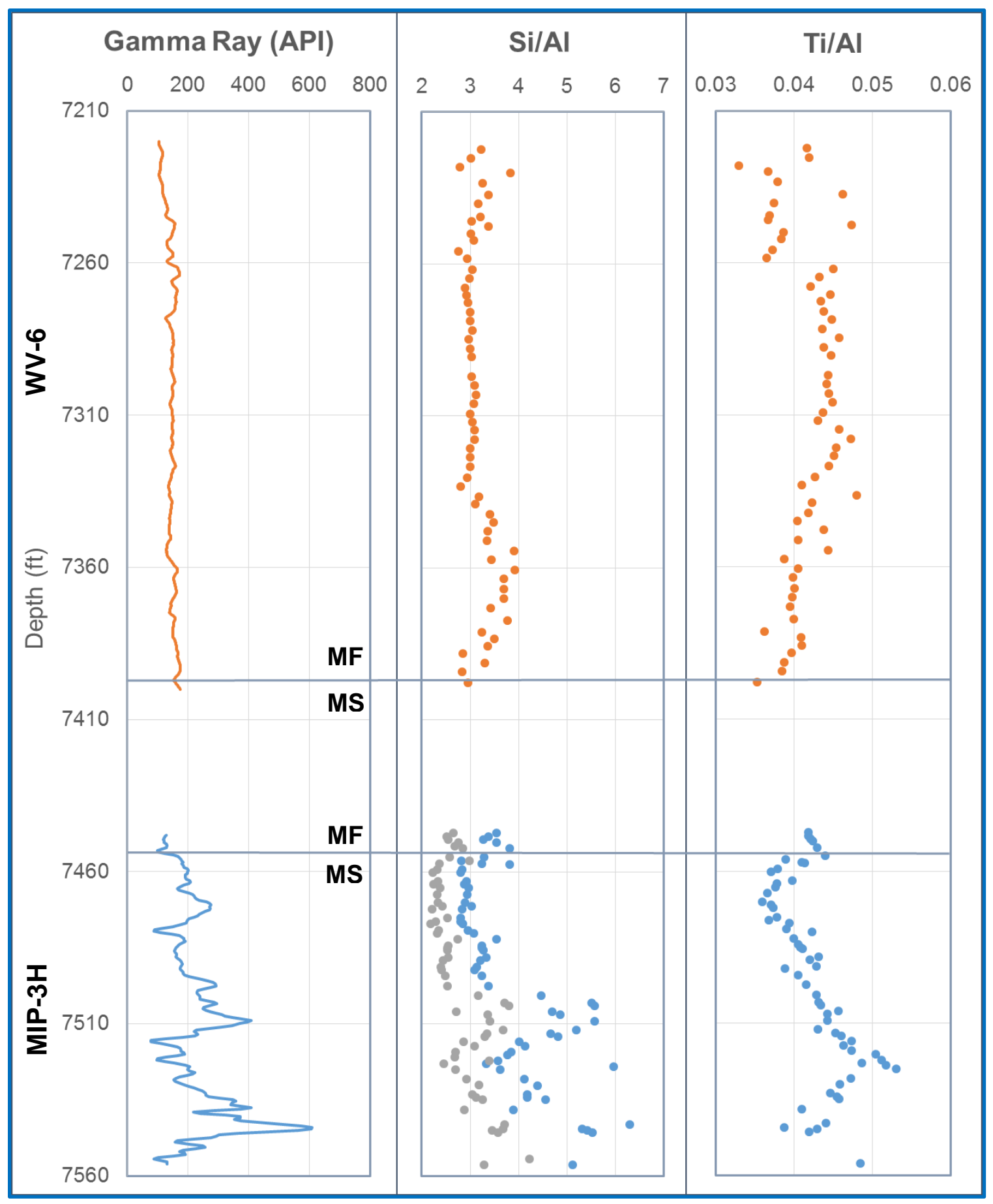

Figure 28. Gamma ray from the MIP-3H (blue) and the WV-6 (orange) wells in comparison to major element ratios, specifically $\mathrm{Si} / \mathrm{Al}$ and Ti/Al. The contacts separating the Marcellus Shale from the overlying Mahantango Formation in each well are indicated by the gray horizontal lines. The gray dots represent major element $\mathrm{pXRF}$ counts ratios. 


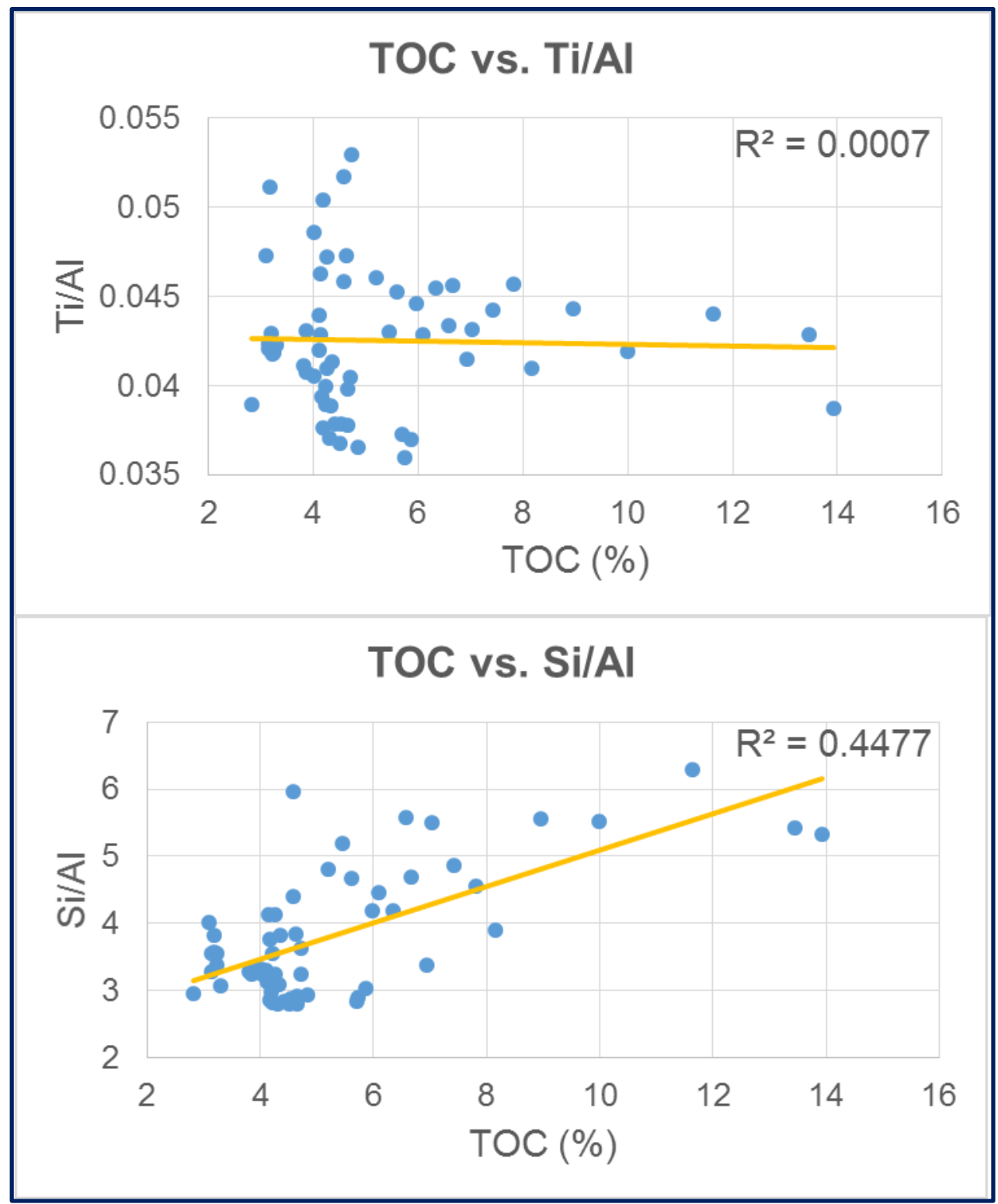

Figure 29. Cross-plots of TOC vs. Ti/Al (A) and vs. Si/Al (B) comparing organic content to sedimentation proxies within the MIP-3H samples.

primary production as reflected by organic-matter content (Fig. 30A-B) No correlation was exhibited within either of these cross-plots $\left(\mathrm{P}_{2} \mathrm{O}_{5}, \mathrm{R}^{2}=0.0055 ; \mathrm{FeO}, \mathrm{R}^{2}=0.0505\right)$, suggesting that production may not have been the limiting factor in controlling organic content but rather the preservation played a more important role. A cross-plot of TOC vs. 


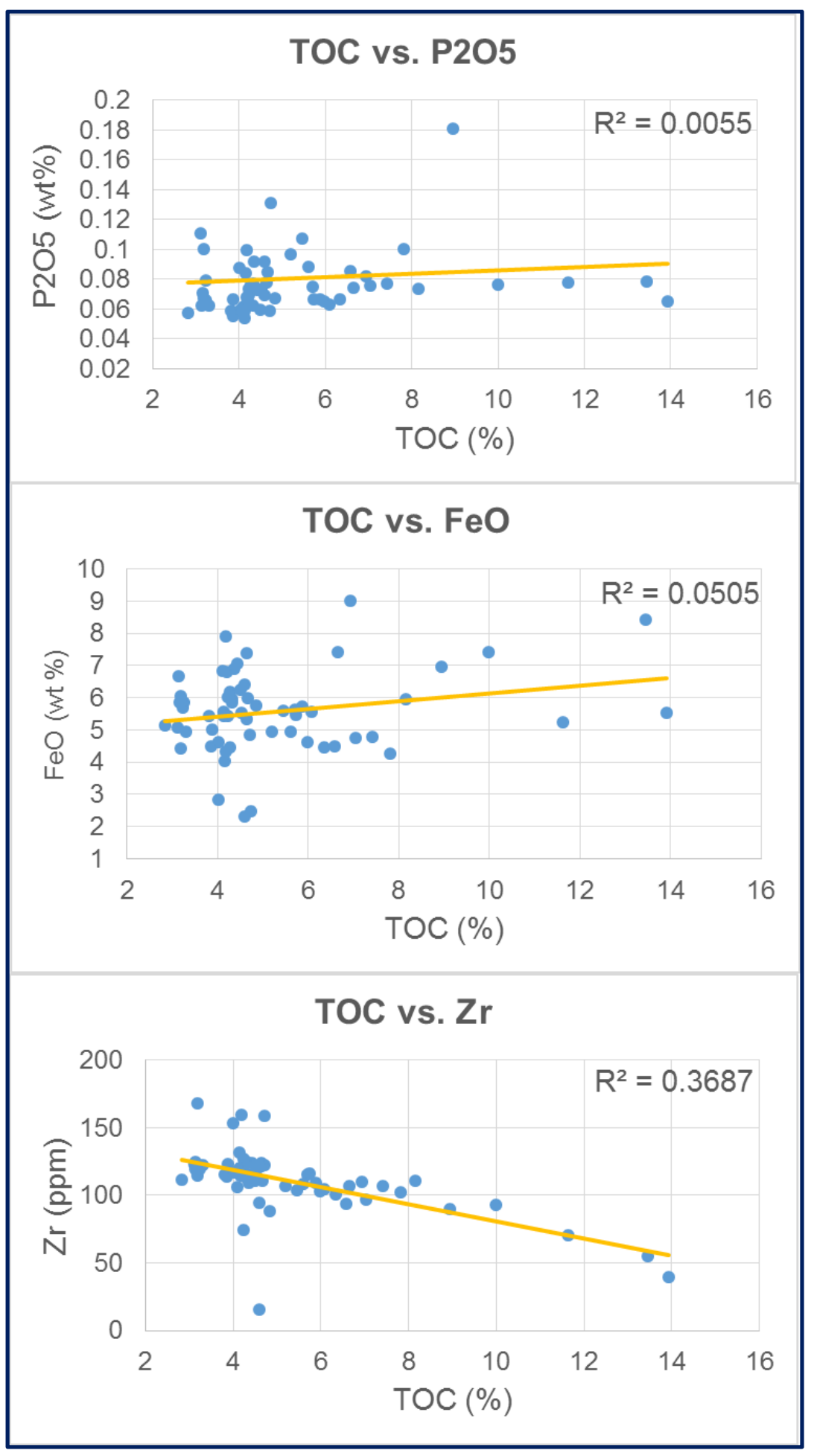

Figure 30. Cross-plots comparing TOC as a proxy for organic matter content to (A) $\mathrm{P}_{2} \mathrm{O}_{5}$, (B) $\mathrm{FeO}$, and (C) $\mathrm{Zr}$. The TOC and cross-compared data are all from the MIP-3H due to a range in organic matter content ranging from $\sim 3-16 \mathrm{wt} \%$. $\mathrm{P}_{2} \mathrm{O}_{5}$ and $\mathrm{FeO}$ serve as proxies for available nutrient input to the basin for primary production. $\mathrm{Zr}$ serves as a proxy for heavy-mineral influx to the basin, which is typically a sign of sedimentation for a recycled sedimentary rock source. 
$\mathrm{Zr}$ shows a negative correlation $\left(\mathrm{R}^{2}=0.3687\right)$ suggesting that increases in influx of recycled sediment directly correlates to decreases in content of organic matter.

Weathering indices for all samples throughout both formations were examined within both the carbonate and siliciclastic facies. However, cross-plots of calcite in comparison to each of the weathering indices, using the MIP-3H samples, show a strong correlation indicating high calcite content negatively correlates to lower CIA $\left(\mathrm{R}^{2}=0.697\right)$ and CIW $\left(R^{2}=0.6503\right)$ values and higher ICV values $\left(R^{2}=0.7241 ;\right.$ Fig. 31$)$. Thus, calcite influenced the weathering indices to show lower weathering intensities in carbonate-rich samples, accounting for outliers among the trends. This relationship was explored using data from the MIP-3H due to its higher abundance of carbonate layers compared to Mahantango Formation sampled from the WV-6 well.

The Marcellus Shale shows CIA values ranging from 0.67 to 74.13 (Fig. 32; Appendix X). For the entire Marcellus Shale sample suite, the average CIA was $54.95 \pm$ $18.19(\mathrm{n}=59)$. When removing carbonate-rich (calcite+dolomite $>10 \%)$ samples from the suite ( $\mathrm{n}=51 ; 8$ removed), the siliciclastic facies (Clusters $1-4)$ had an average CIA of $60.56 \pm 11.32$. CIW values for the Marcellus Shale ranged from 0.68 to 91.63 , with a full sample suite average of $65.90 \pm 23.51$ and the siliciclastic CIW average of $73.01 \pm 15.49$. Both the CIA and CIW values show an increasing trend up-section within the Marcellus Shale. ICV values within the Marcellus Shale averaged $3.29 \pm 11.78$ within the full suite, with an average siliciclastic fraction ICV of $1.04 \pm 0.36$. Values ranged between 0.69 and 81.99 and show a decreasing trend up-section. 


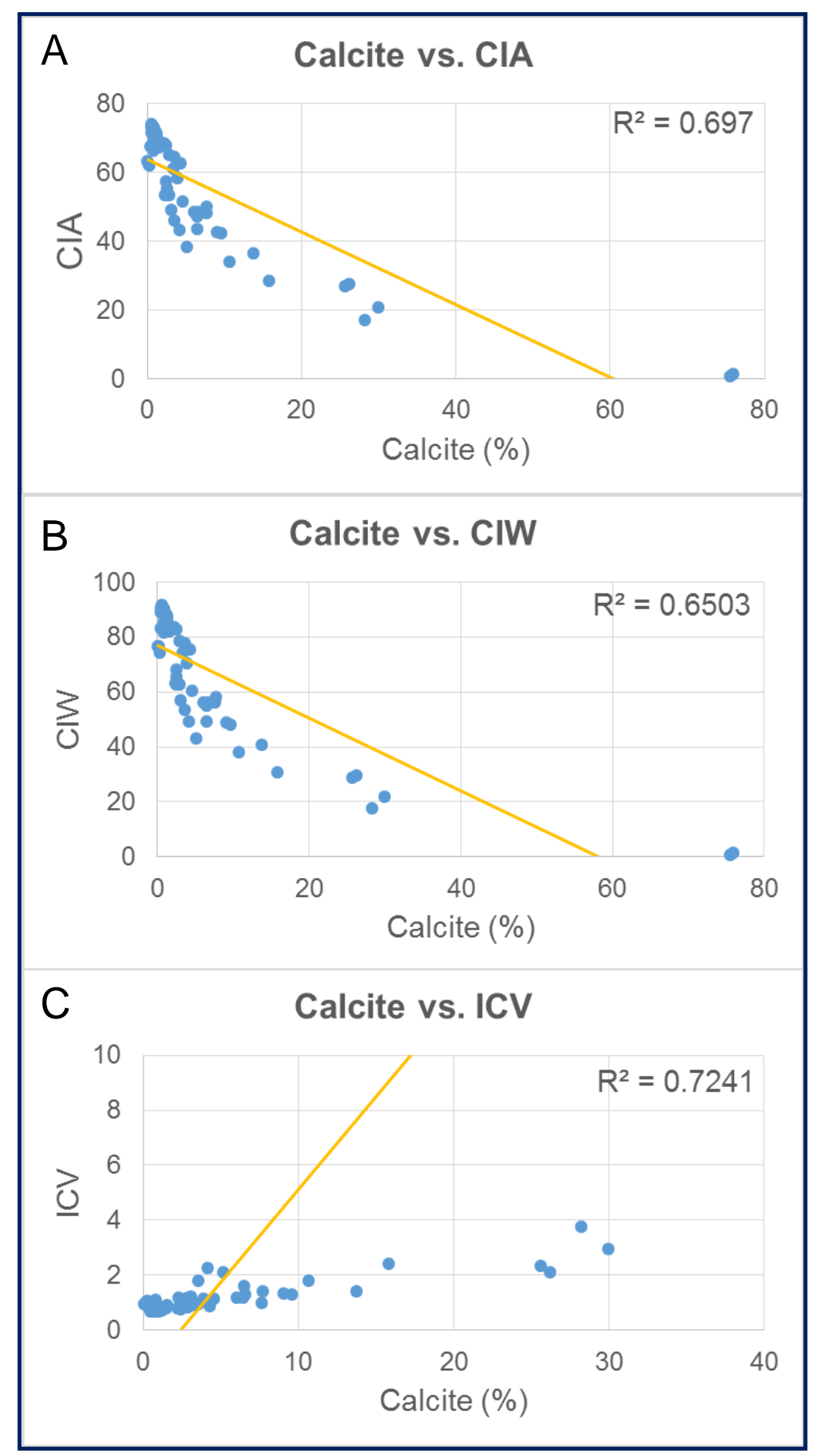

Figure 31. Cross-plots of CIA (A), CIW (B), and ICV (C) versus calcite to show the strong correlations indicating that calcite-rich samples will yield weathering index values that indicate lower weathering intensities within all three indices. 


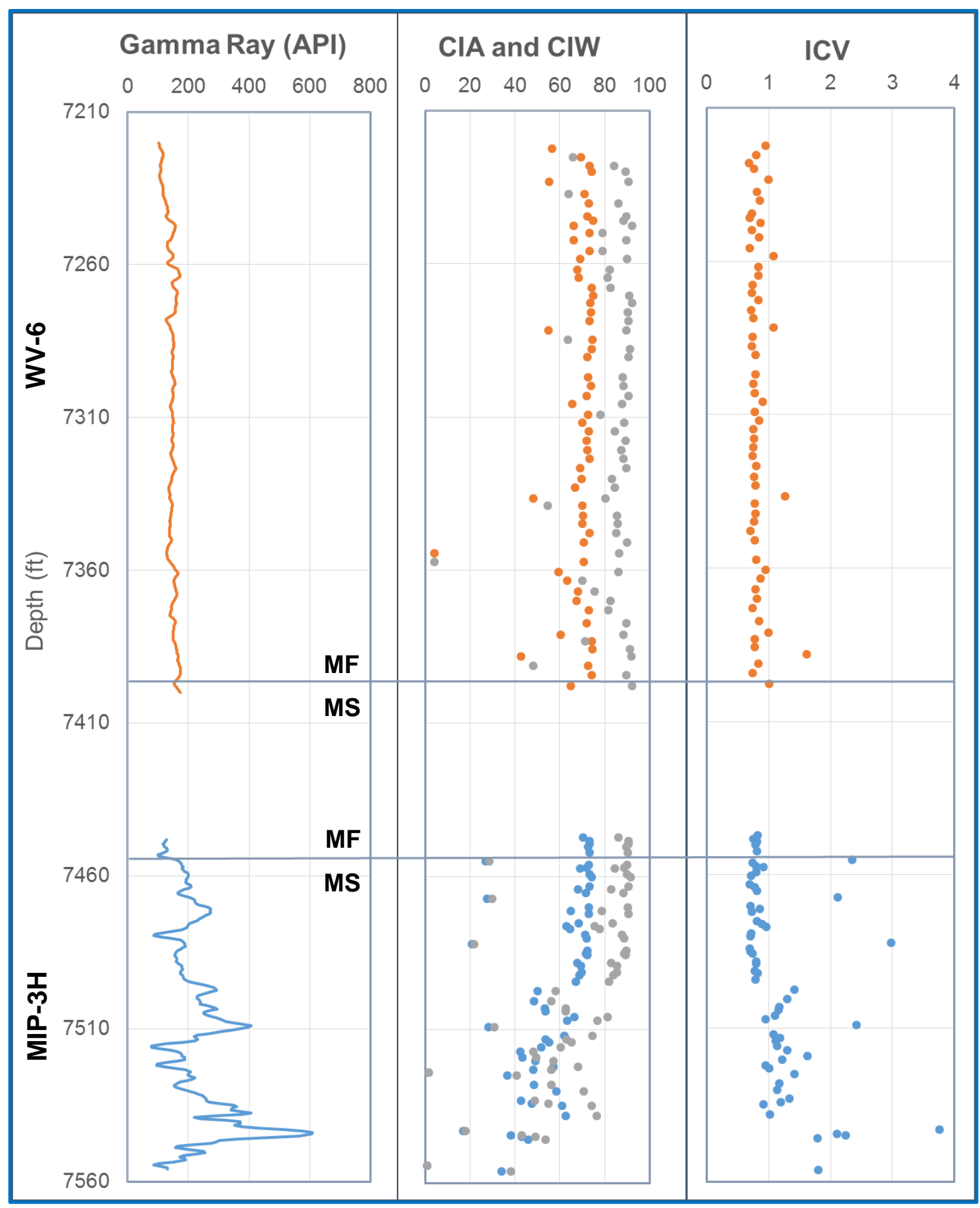

Figure 32. Weathering indices calculated for the WV-6 and MIP-3H samples. From left to right is the gamma-ray log, chemical index of alteration (CIA; blue/orange), chemical index of weathering (CIW; gray), and index of compositional variability (ICV). 
Siliciclastic facies within the Mahantango Formation $(n=62)$ had CIA values averaging $69.51 \pm 6.47$ and CIW values averaging $84.43 \pm 9.14$ (Fig. 32; Appendix XI). CIA values ranged from 4.05 to 74.96 , while CIW values ranged from 4.08 to 92.13 . There was only one carbonate-rich (calcite+dolomite $=\sim 72 \%$ ) sample found within the Mahantango Formation suite, making the full sample suite $(n=63)$ average CIA value $68.47 \pm 10.45$ and average CIW value 83.16 \pm 13.59 . ICV values for the Mahantango Formation averaged at $0.82 \pm 0.14$ within the silicate fraction, and $1.06 \pm 1.88$ within the full sample suite. The Mahantango Formation does not show any great variation or trends in regards to weathering indices compared to the indices indicating increased weathering intensity found up-section throughout the Marcellus Shale (Fig. 32).

Element comparisons in various discrimination and ternary diagrams help to determine mudstone provenance. The $\mathrm{Al}_{2} \mathrm{O}_{3}-\left(\mathrm{CaO}+\mathrm{Na}_{2} \mathrm{O}\right)-\mathrm{K}_{2} \mathrm{O}$ ternary diagram depicts the relationships between major element abundances used to calculate CIA (Fig. 33; Nesbitt and Young, 1984, 1989; McLennan, 1993). Both the Marcellus Shale and Mahantango Formation samples tend to follow the typical weathering trend of a granodiorite. Similarly, $\mathrm{Al}_{2} \mathrm{O}_{3}-\left(\mathrm{CaO}+\mathrm{Na} 2 \mathrm{O}+\mathrm{K}_{2} \mathrm{O}\right)-\left(\mathrm{FeO}_{\text {total }}+\mathrm{MgO}\right)(\mathrm{Nesbitt}$ and $\mathrm{Young}$, 1984, 1989; McLennan, 1993) indicate Marcellus Shale and Mahantango Formation samples follow a granodioritic weathering trend (Fig. 34). Discrimination diagrams calculated from major element composition data established by Roser and Korsch (1988) helped to further delineate source type by differentiating between a quartzose sedimentary source, felsic igneous source, intermediate igneous source, and mafic igneous source. The Marcellus Shale composition indicated a felsic igneous source with 


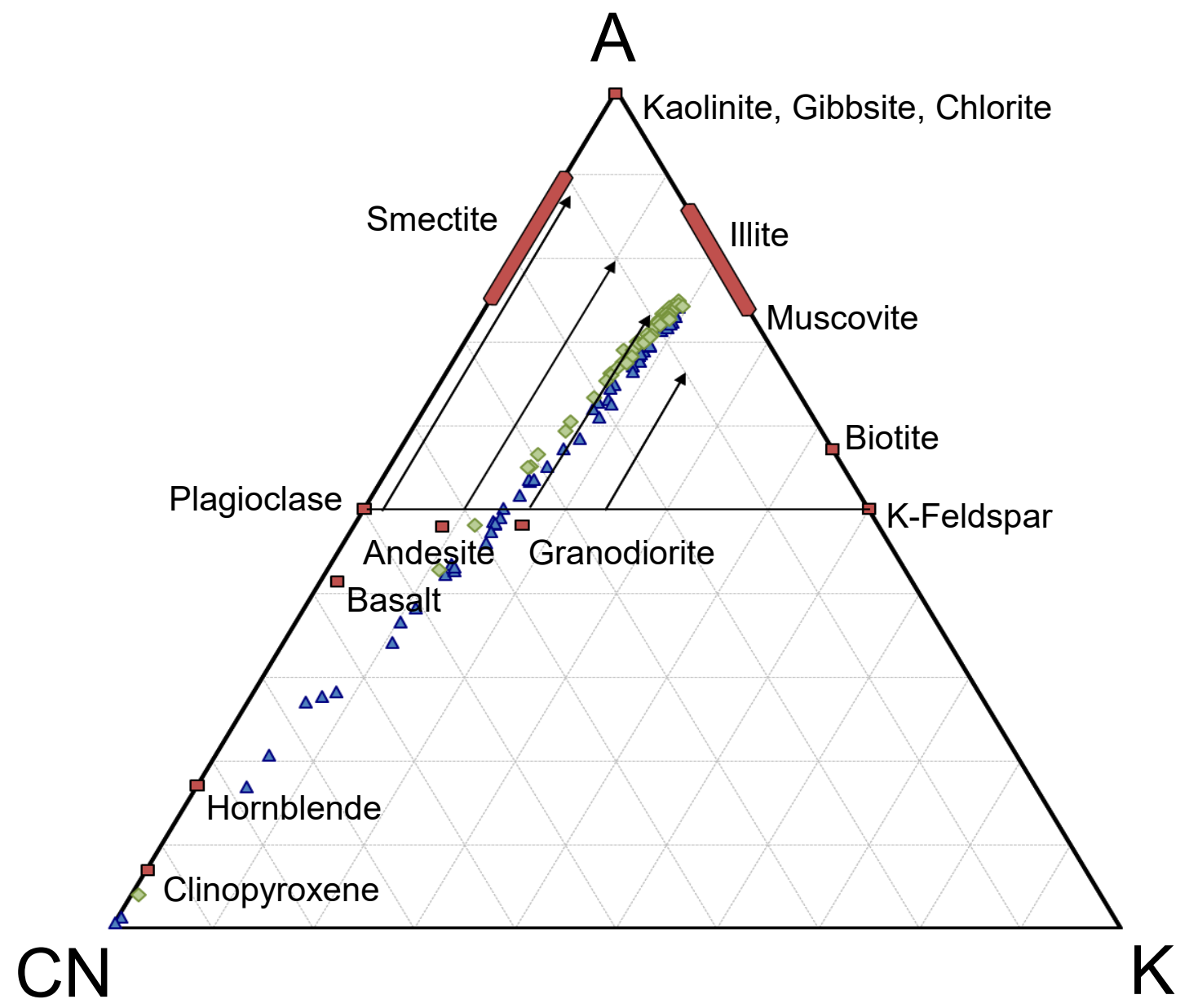

Figure 33. A-CN-K $\left(\mathrm{Al}_{2} \mathrm{O}-(\mathrm{CaO}+\mathrm{NaO})-\mathrm{K}_{2} \mathrm{O}\right)$ ternary diagram showing how major element chemistry data collected from the Mahantango Formation (green diamonds) and Marcellus Shale (blue triangles). Note that samples from both formations on average follow a granodioritic weathering trend. 


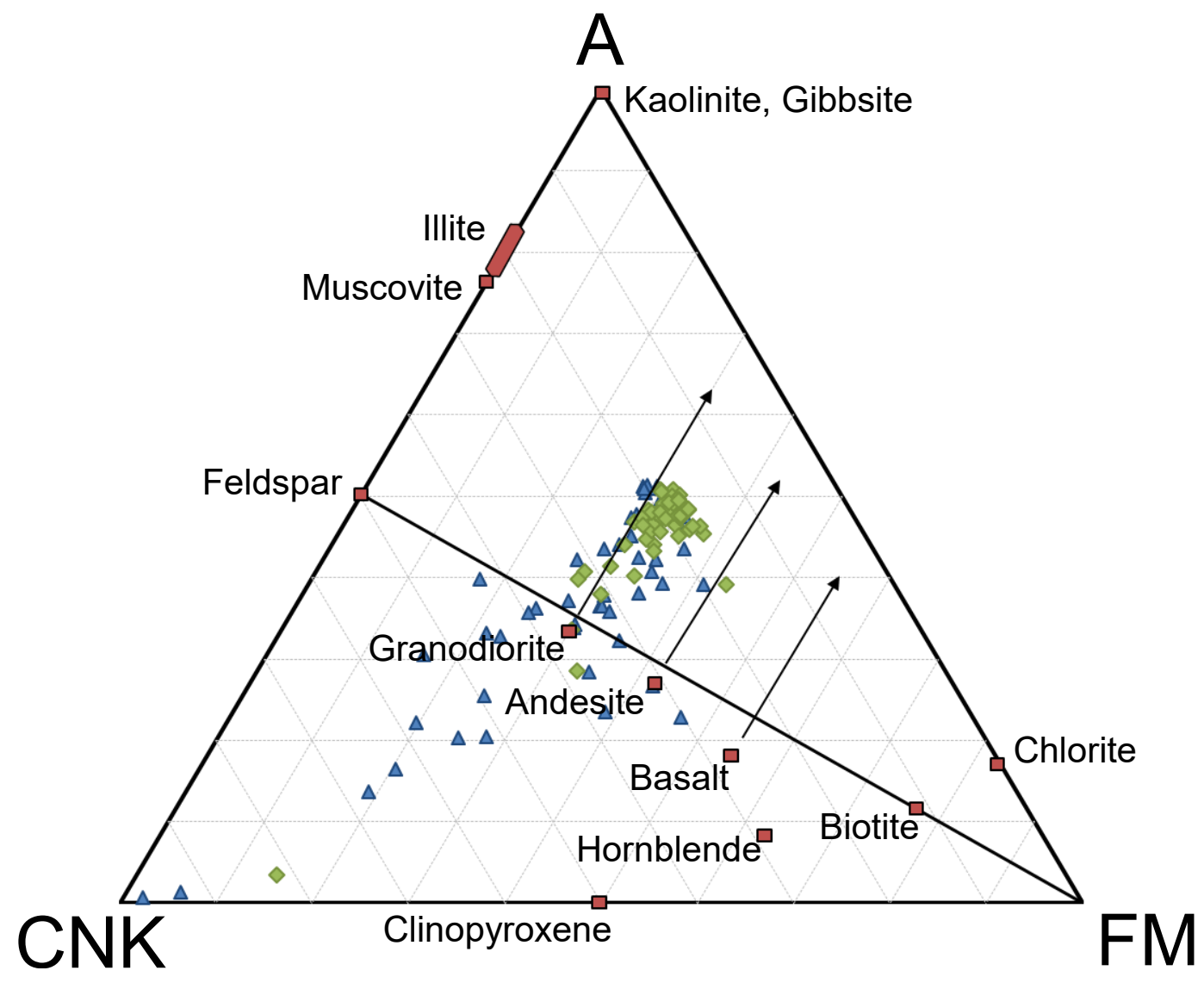

Figure 34. A-CNK-FM $\left[\mathrm{Al}_{2} \mathrm{O}-\left(\mathrm{CaO}+\mathrm{NaO}+\mathrm{K}_{2} \mathrm{O}\right)-(\mathrm{FeO} *+\mathrm{MgO})\right]$ ternary diagram showing how major element chemistry data collected from the Marcellus Shale (blue triangles) and Mahantango Formation (green diamonds) to help in identifying composition of the original source rock. The rocks of the Mahantango Formation consistently show a granodiorite weathering trend, whereas the Marcellus Shale data shows greater compositional variability. 
some minor influence from a quartzose sedimentary source, whereas the Mahantango Formation mainly reflects dominance of a felsic igneous source (Fig. 35).

Trace element ternary diagrams, such as La-Th-Sc further constrain provenance terrain type (McLennan et al., 1990; Ma et al., 2015). Both the Mahantango Formation and Marcellus Shale plot nearest to an upper crust source, though, the Marcellus Shale shows more compositional variability than the Mahantango Formation (Fig. 36). Crossplots of $\mathrm{Zr} / \mathrm{Sc}$ vs. Th/Sc were used to identify signs of sediment recycling (McLennan et al., 1993; Fig. 37). The Marcellus Shale showed some influence of sediment recycling, whereas the Mahantango Formation showed no signs of influence from a recycled sedimentary source.

Elemental evaluation of the Marcellus Shale suggested a dominantly felsic igneous, granodioritic source with additional input from a recycled quartzose sedimentary source. The Mahantango Formation consistently showed geochemical composition indicating sediment influx from weathering of a granodioritic, felsic igneous source. 

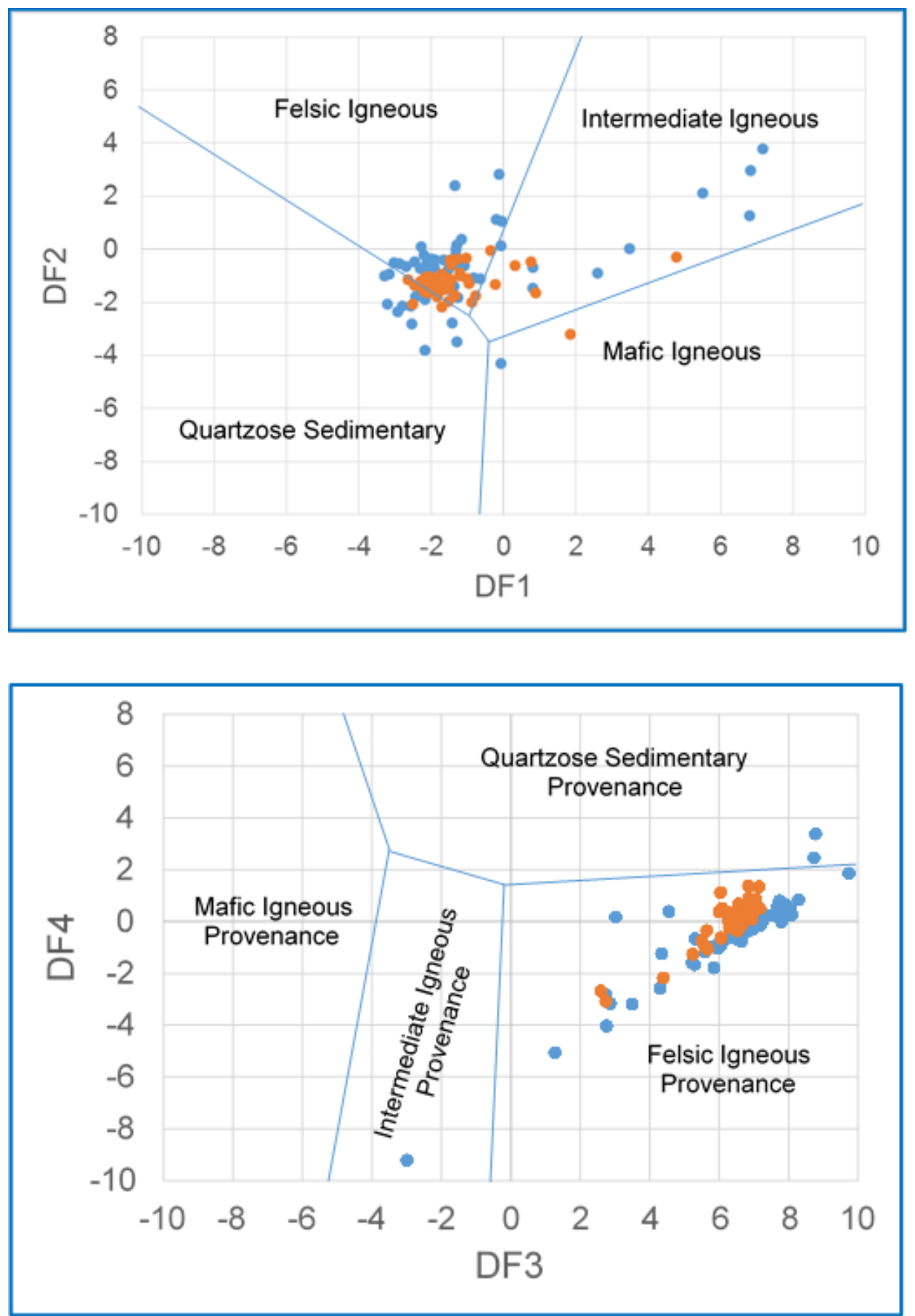

Figure 35. Discrimination diagrams used to determine the composition of the source rock for the Mahantango Formation (orange) and the Marcellus Shale (blue). Differential functions DF1 and DF2 are to evaluate rocks independent of biogenic influence, whereas DF3 and DF4 are to evaluate source composition of rocks that have been influenced by biogenic sedimentation. 


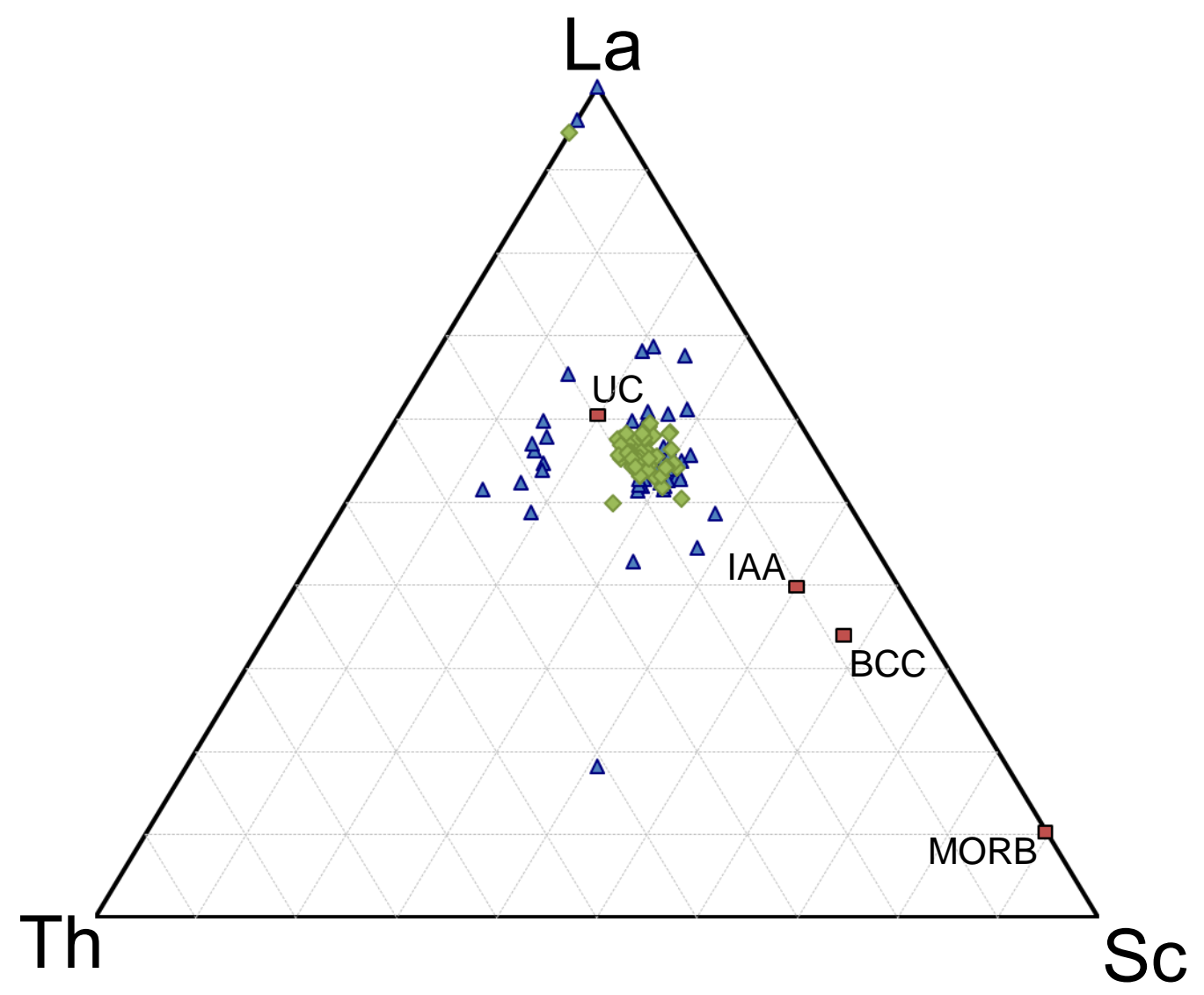

Figure 36. La-Th-Sc trace element ternary diagrams from the Mahantango Formation (green diamonds) and the Marcellus Shale (blue triangles) are shown above. Abbreviations within each diagram are as follows: $\mathrm{UC}=$ Upper Crust; IAA= Island Arc Andesite; $\mathrm{BCC}=$ Bulk Continental Crust; MORB $=$ Mid-Ocean Ridge Basalt. Note that both the Mahantango Formation and Marcellus Shale plot dominantly within the upper crustal source region of the diagram. 

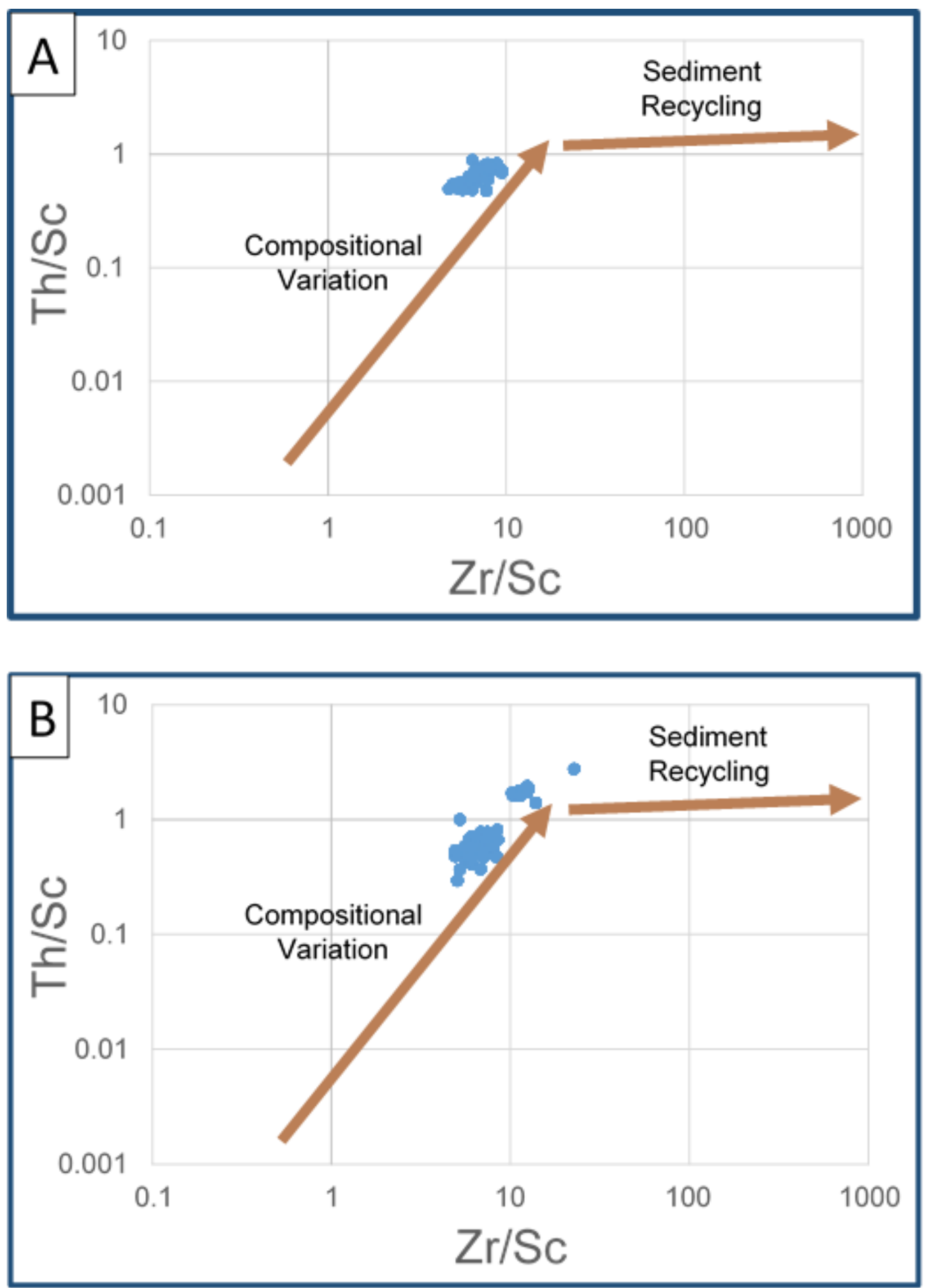

Figure 37. Trace element cross-plots of $\mathrm{Zr} / \mathrm{Sc}$ vs. Th/Sc relationships with data from the Mahantango Formation (A) and Marcellus Shale (B). The plots help to show if there are signs of a recycled sedimentary source through zirconium enrichment for each of the two formations. 


\subsubsection{Sm-Nd Isotopic Dating Results}

Of the ten samples that were analyzed for $\mathrm{Sm}-\mathrm{Nd}$ radiogenic isotopes, only nine samples presented valid results. One anomalous sample recorded an $\varepsilon_{\mathrm{Nd}}$ value of -7.06, whereas the remaining nine samples ranged from -9.85 to -11.74 (Table 3, Fig. 38, Appendix XIV). Depleted mantle model ages $\left(\tau_{\mathrm{DM}}\right)$ were calculated, resulting in model ages ranging from 1.85-1.64 Ga, with the anomalous sample providing a model age of $5.33 \mathrm{Ga}$. Cross-plots of Th/U vs. $\varepsilon_{\mathrm{Nd}}$ values further indicate an upper crustal composition of the source rock (Fig 39).

Table 3. Sm-Nd isotopic data from ten samples throughout the Mahantango Formation (blue; $\mathrm{n}=5$ ) and Marcellus Shale (brown; $\mathrm{n}=5$ ) including the well they were collected from, sample depth, $\varepsilon_{\mathrm{Nd}}$ values, $\tau_{\mathrm{DM}}$ model ages, LOI at $600^{\circ} \mathrm{C}$ as a proxy for organic-matter content, and mineralogical cluster. In some samples, LOI was not reported.

\begin{tabular}{cccccc}
\hline Well & Depth (ft.) & ENd & $\boldsymbol{\tau}$ DM $($ Ga) & LOI & Min. Cluster \\
\hline WV-6 & 7225.3 & -11.65 & 1.65 & 5.6 & WV6-C2 \\
WV-6 & 7270.3 & -11.47 & 1.67 & 6.5 & WV6-C2 \\
WV-6 & 7314.7 & -11.74 & 1.64 & 6.5 & WV6-C2 \\
WV-6 & 7360.5 & -10.38 & 1.74 & 6.9 & Qtz-rich outlier \\
MIP-3H & 7448.35 & -10.34 & 1.85 & 7.89 & MIP3H-C2 \\
MIP-3H & 7460.2 & -10.51 & 1.79 & unkn & MIP3H-C2 \\
MIP-3H & 7489.06 & -10.55 & 1.63 & 7.62 & MIP3H-C2 \\
MIP-3H & 7505.93 & -10.18 & 1.81 & 11.20 & MIP3H-C4 \\
MIP-3H & 7538.15 & -9.85 & 1.78 & unkn & MIP3H-C3 \\
MIP-3H & 7544.85 & -7.06 & 5.34 & 11.03 & MIP3H-C1 \\
\hline
\end{tabular}


One of ten $\mathrm{Sm}-\mathrm{Nd}$ data points $\left(7544.85 \mathrm{ft}\right.$.) yielded extreme $\varepsilon_{\mathrm{Nd}}$ and calculated $\tau_{\mathrm{DM}}$ due to the depletion of $\mathrm{Nd}$ within the sample. Studies of other Paleozoic shales have found anomalous $\mathrm{Sm}-\mathrm{Nd}$ data that have led to erroneous model ages, and there are many possible mechanisms for this depletion (McLennan et al., 1990; Bock et al., 1994). One possibility could be early diagenesis in which the breakdown of unstable minerals could cause REEs to be released and subsequently collected into phosphate minerals within the organic-rich layers. Within the 7544.85 sample, TOC is greater than $17 \%$, and has a higher concentration of Sr-barite at $32 \%$. Thus, based on XRD mineralogy results, phosphate bearing-minerals are not observed in the study samples, ruling out influence of REEs from phosphatic minerals. A second, more probable possibility is that these upper crustal sourced sediments experience mixing with LREE-depleted volcanic ashes that were falling intermittently at this time. Tioga ashes can be found throughout the lower Marcellus Shale. However, further examination of the MIP-3H core shows there are not any ash beds stratigraphically near this sample. 


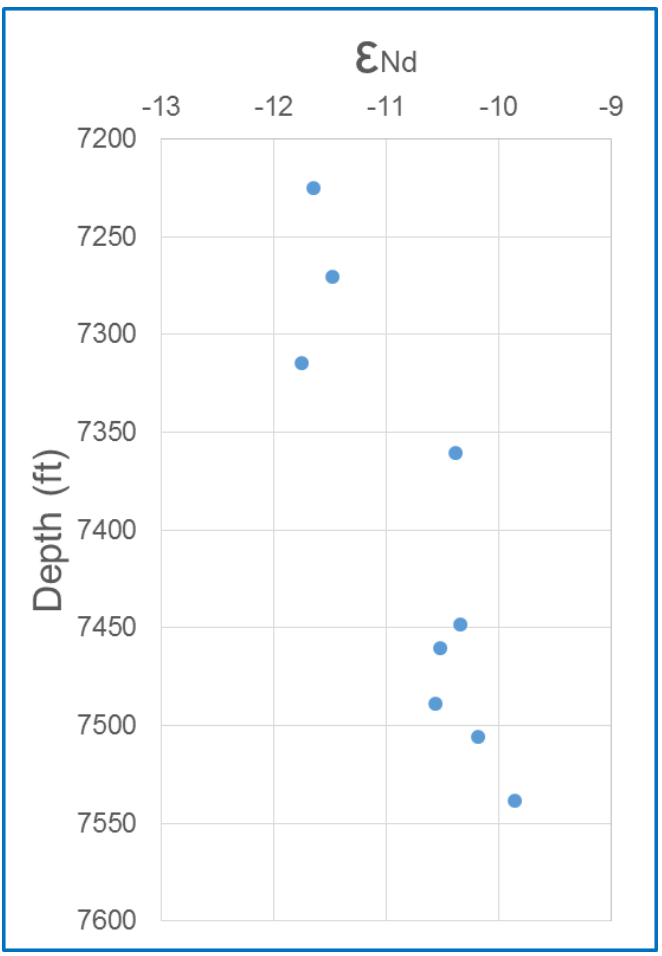

Figure 38. $\varepsilon_{\mathrm{Nd}}$ values for nine samples, excluding the anomalous data point, throughout the Hamilton Group. Note the general decrease in epsilon values up section.

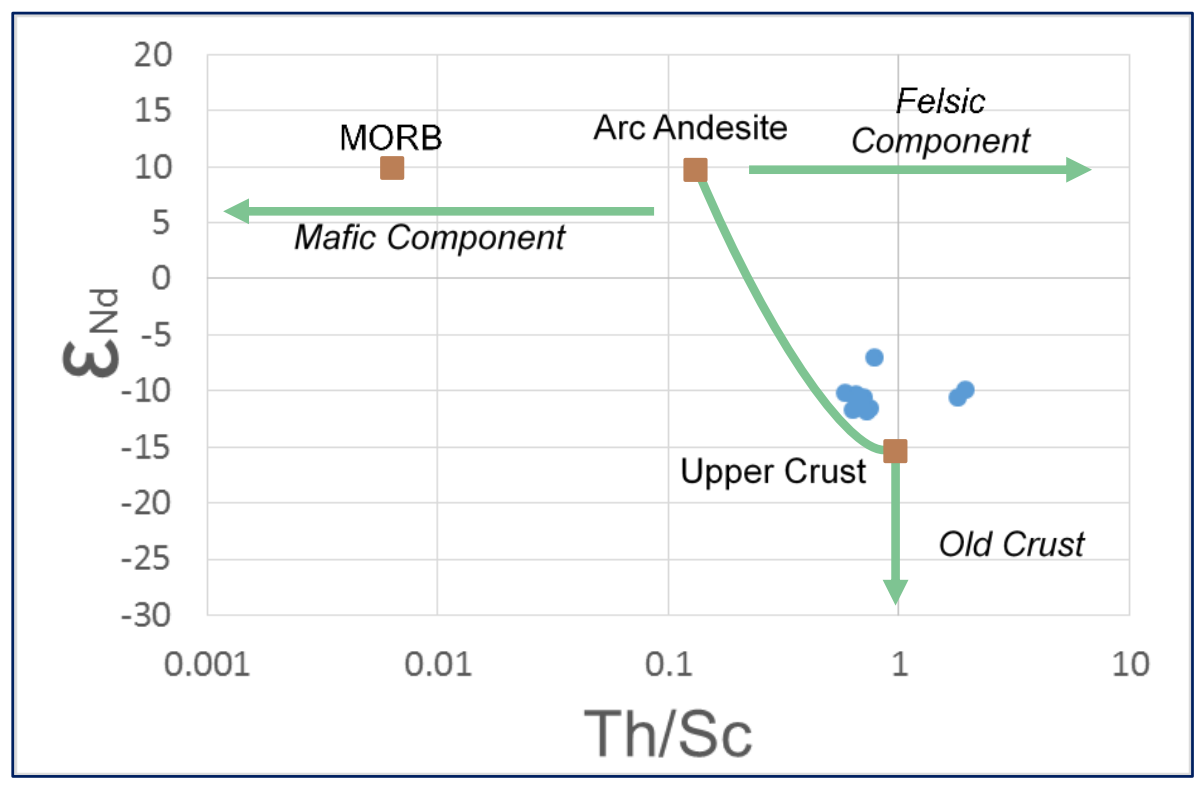

Figure 39. Cross-plot of Th/Sc vs. $\varepsilon_{\mathrm{Nd}}$ values to identify source rock type. All ten data points plot near the upper crust compositional end-member. 


\section{DISCUSSION}

\subsection{Constraints on sediment influx from Hamilton Group petrography and mineralogy}

Five mineralogically defined petrofacies were established using cluster analysis of extrabasinal and intrabasinal mineralogical phases along with bulk geochemical compositions and organic matter abundance. Organic matter abundance was determined from gamma ray wireline logs, LOI at $600^{\circ} \mathrm{C}$, and TOC (Fig. 40; meesl.org). The continuous gamma-ray derived TOC log shows uranium-predicted TOC, whereas the measurements were collected by the DOE-National Energy Technology Laboratory in Morgantown, WV using a source rock analyzer (SRA; mseel.org). TOC SRA measurements were collected at the bottom of each $3 \mathrm{ft}$. break in the core. The SRA TOC measurements from the core were cross-plotted with the geophysical gamma ray log in order to establish an equation to calculate a continuous TOC log.

Clay-rich petrofacies are characterized by samples with greater than $70 \%$ illite+muscovite, but do not have any chlorite. TOC values are $\sim 4-14 \%$. These petrofacies are most abundant in the lower and middle Marcellus Shale, and comprise $\sim 35 \%$ of the Marcellus Shale. The clay-rich petrofacies forms the organic-rich section of the lower Marcellus Shale. Most thin-sections in this petrofacies are identified as argillaceous sarls and claystones, with minor silty claystones. Two samples of biosiliceous tarl lithofacies are contained within the clay-rich petrofacies and show abundant radiolarians, providing evidence of clear surface waters and sufficient nutrient flux to support primary biologic productivity that would allow these pelagic zooplankton to thrive (Milliken et al., 2012). These conditions likely contributed to increased production of organic matter. Although XRD data indicates illite and muscovite making up much of 


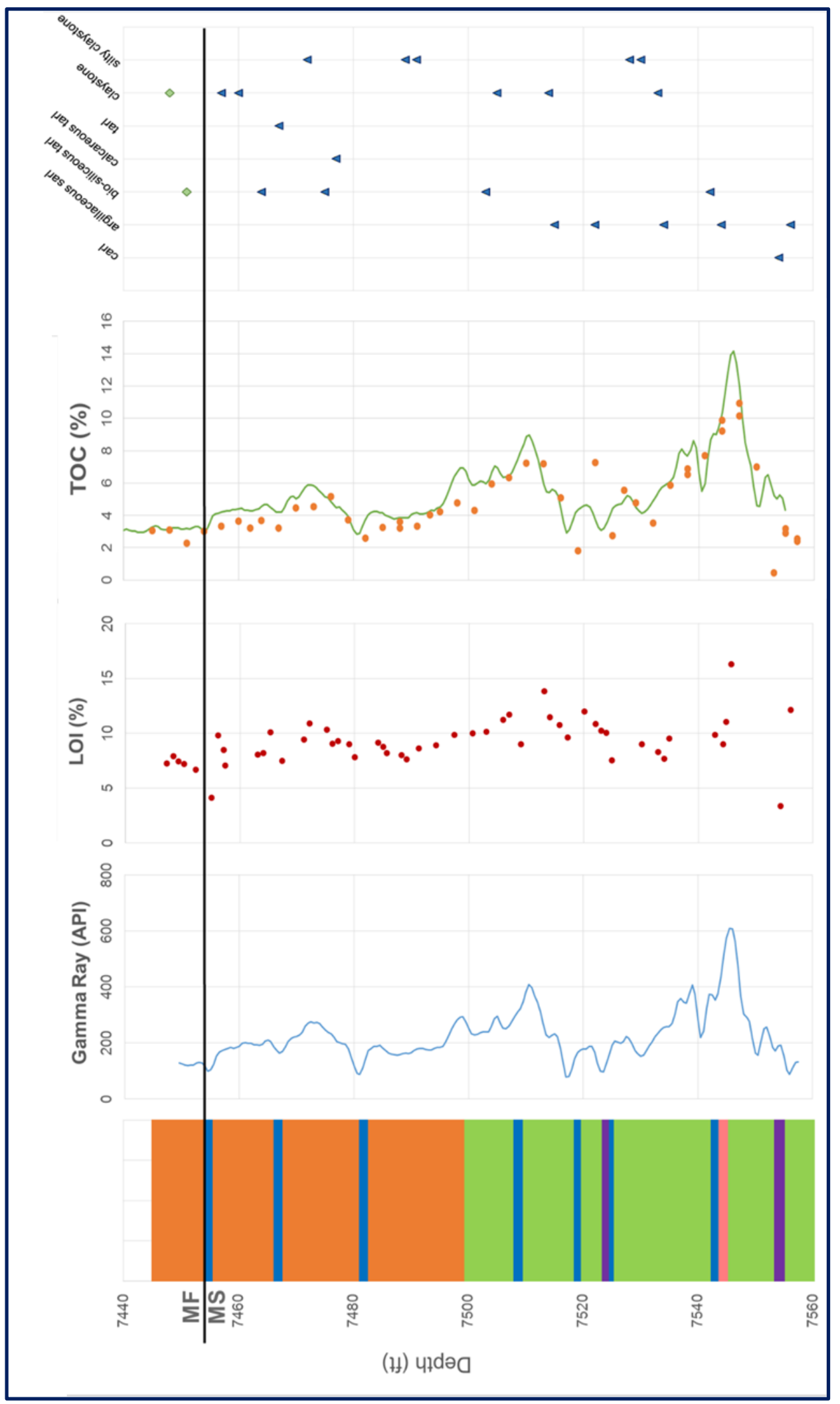

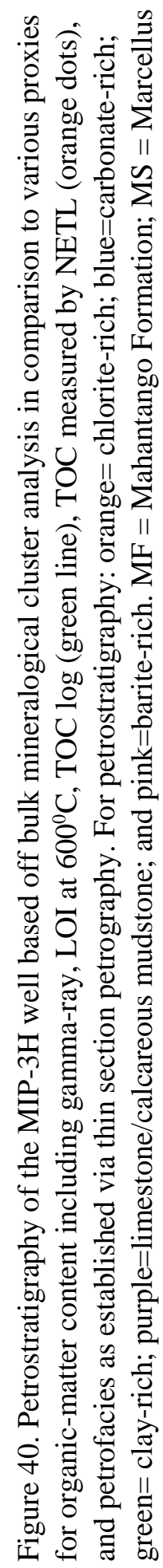


the matrix, this additional input from extrabasinal sources did not cause substantial dilution of organic matter. Instead, deposition was dominated by relatively higher rates of pelagic sedimentation compared to hemipelagic sedimentation.

The chlorite-rich petrofacies were characterized by samples with high concentrations of illite, muscovite, quartz, and chlorite. Chlorite in this petrofacies averages $7.1 \%( \pm 0.8 \%)$, whereas it is absent in all other petrofacies. TOC abundances are overall lower in this petrofacies, ranging from $\sim 2-6 \%$. The chlorite-rich petrofacies of the upper Marcellus Shale and Mahantango Formation units are mainly composed of organic-poor lithofacies, and thin-sections primarily claystones and silty claystones. Thus, the lower organic-matter content within these lithofacies is due to deposition of hemipelagic detrital clay influx in low oxygen, low energy bottom waters. Organisms such as the highly-efficient agglutinated foraminifera observed in thin-sections, suggest that the benthic environment was characterized by suboxic conditions (Fig. 20). Abundance of clay pellets and authigenic pyrite crystals indicate epifaunal invertebrate detrital feeders and sulfur-fixing bacteria were also present in this dysoxic environment. Although bottom-water conditions were dysoxic, benthic organisms were able to persist, producing the intrabasinal grains found throughout this petrofacies. However, the concentration of organic matter in the chlorite-petrofacies has been diluted by detrital clay influx to the basin.

Approximately $20 \%$ of the analyzed samples have mineralogical compositions distinctive from the clay-rich and chlorite-rich petrofacies. These samples were grouped into three petrofacies dominated by non-organic intrabasinal phases. These petrofacies seem to characterize thin intervals of the Hamilton Group that are interbedded within the 
more abundant chlorite-rich and clay-rich petrofacies. The barite-rich petrofacies is defined by samples containing $>20 \%$ barite. Two samples interbedded in the clay-rich petrofacies of the lower Marcellus Shale are identified as barite-rich petrofacies. The carbonate-rich petrofacies is defined as samples with calcite and dolomite composing 10$70 \%$ of their overall mineralogical make-up. Seven samples were found interbedded throughout both the clay-rich and chlorite-rich petrofacies of the Marcellus Shale. The limestone/calcareous mudstone petrofacies differs from the carbonate-rich petrofacies in that greater than $70 \%$ of its mineral constituents are composed of calcite and dolomite. Just two samples of the limestone/calcareous mudstone are found interbedded in the clayrich petrofacies of the lower Marcellus Shale. TOC values for the carbonate-rich and limestone/calcareous mudstone petrofacies are typically lower than in the deposits immediately above and below these beds.

Overall, mineralogy of the Hamilton Group mudrocks includes both intrabasinal and extrabasinal sedimentation components. Intrabasinal phases include calcite, dolomite, gypsum, barite, pyrite, and authigenic or biogenic silica recrystallized into quartz. Samples that contain $>30 \%$ intrabasinal mineral phases were typically found in the lower Marcellus Shale, where TOC values are low $(<\sim 3 \%)$ and constitute the barite-rich, calcite-rich and limestone/calcareous mudstone petrofacies. Extrabasinal phases included quartz when associated with quartz silt grains observed in thin-section, illite, muscovite, chlorite, and albite. These phases form the bulk of the clay-rich and chlorite-rich petrofacies that dominate the upper Marcellus Shale and lower Mahantango Formation, where $\geq 70 \%$ or more of the mineralogical constituents composed of non-authigenic/nonbiogenic quartz, muscovite, illite, chlorite, and/or albite. The upper Marcellus Shale to 
lower Mahantango Formation contained a higher percentage of extrabasinal sediment at $89 \%$ than what is found within the middle (84\%) or lower (81\%) Marcellus Shale.

Mineralogical and petrographic observations suggest transitions in environmental conditions during deposition of the studied formations influenced sedimentation patterns and preservation of organic matter. Petrographic investigation of the lower Marcellus Shale indicated sufficient nutrient flux to support high primary productivity and subsequent organic matter deposition. In contrast, bottom-water conditions during the deposition of the upper Marcellus Shale and the Mahantango Formation were characterized by dysoxic marine bottom-water conditions and increased terrigenous influx to the basin. Sedimentation patterns were thus controlled by pelagic processes throughout the deposition of the Marcellus Shale and hemipelagic processes throughout the deposition of the Mahantango Formation leading to a decrease in organic matter preservation via terrigenous clastic dilution found up-section throughout the Hamilton Group.

\subsection{Source rock lithology from geochemical composition}

Mineralogy and elemental abundances indicate a mainly upper crustal, granodioritic source rock supplied sediment to the study area throughout deposition of the Hamilton Group (Table 4; Fig. 33-36). Discrimination diagrams for major and trace element composition of the Mahantango Formation indicate a felsic igneous source, whereas data from the Marcellus Shale suggests a dominantly felsic igneous source with a few samples exhibiting minor influence from quartzose sedimentary sources (Fig. 35). A few samples of the Marcellus Shale exhibited enrichment of $\mathrm{Zr} / \mathrm{Sc}$ relative to $\mathrm{Th} / \mathrm{Sc}$ 


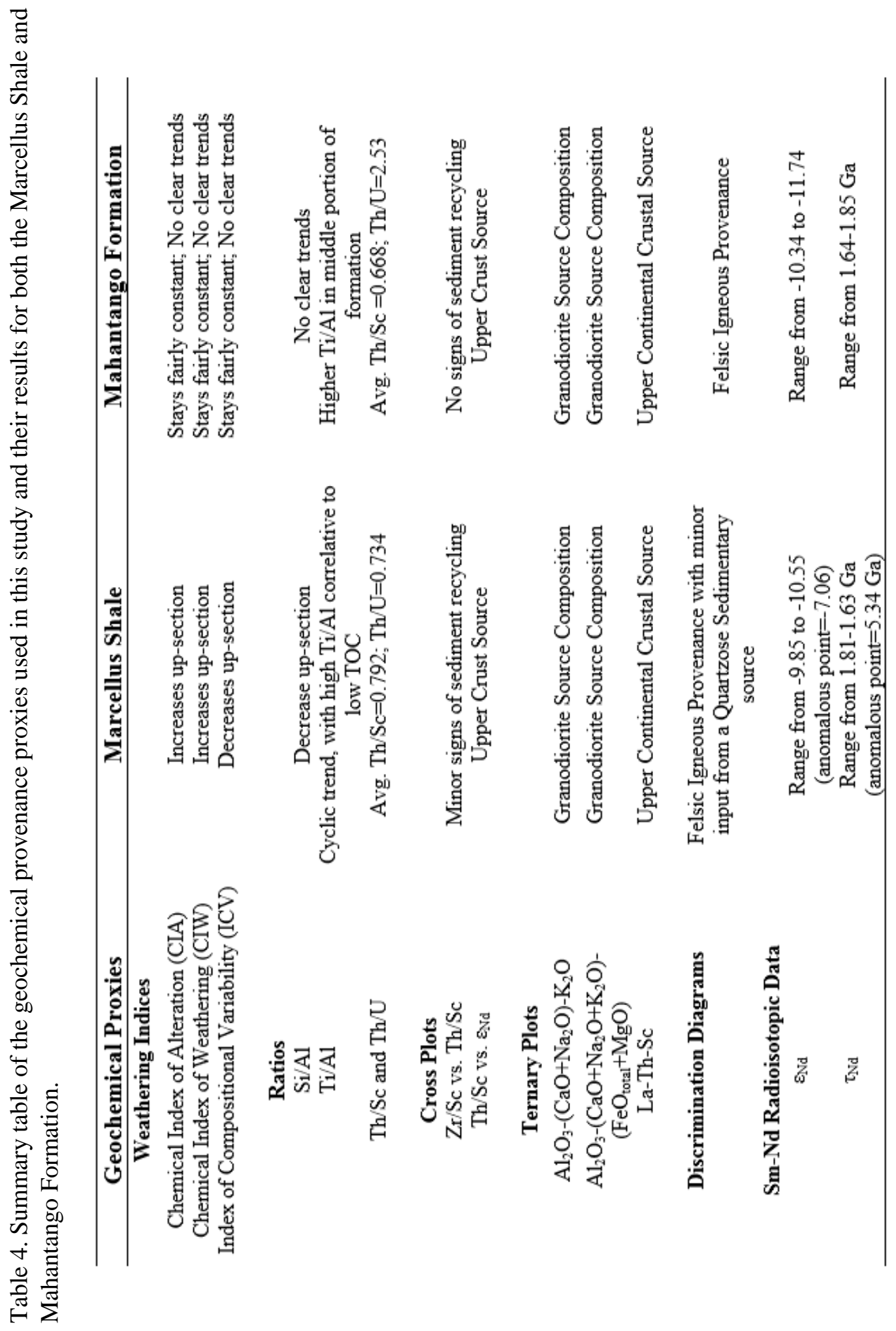


(Fig. 37), supporting minor sediment influx from a recycled sedimentary source. The cross-plot of Th/Sc vs. $\varepsilon_{\mathrm{Nd}}$ is also consistent with an upper crustal source (Fig. 39).

There are two terranes that would produce these signatures when weathered. The Superior Craton to the north-northwest of the basin is an older upper crustal source of primarily granodioritic composition. The Acadian fold-thrust belt to the east would also produce a felsic igneous signature when weathered. However, this terrane would also produce signs of sediment recycling, accounting for influence from quartzose sedimentary source indicated within the discrimination diagrams (Fig. 35).

\subsection{Source area age characterization}

The Sm-Nd results for the Hamilton Group yield depleted mantle model ages ( $\left.\tau_{\mathrm{DM}}\right)$ ranging from 1.85 to $1.63 \mathrm{Ga}$ and $\tau_{\mathrm{DM}}$ ages appear to gradually decrease up-section (Fig. 38; Table 3). The $\varepsilon_{\text {Nd }}$ values for the Hamilton Group samples ranged from -12 to -7, which falls between values from Archean to Mesoproterozoic crustal rocks in North America; however, $\varepsilon_{\mathrm{Nd}}$ values of the Hamilton Group are lower than the values for Mesoproterozoic Grenville rocks, with only the anomalous sample with $\varepsilon_{\mathrm{Nd}}$ of -7 falling within the range of Mesoproterozic crustal rocks (Fig. 41). Ashes from the Acadian arc would have shown $\varepsilon_{\mathrm{Nd}}$ of +2.3 to +3.8 , making it highly unlikely that there was any major input from this source (Shoonmaker et al., 2011).

Because there are no source rocks with the observed $\tau_{\mathrm{DM}}$ ages and $\varepsilon_{\mathrm{Nd}}$ values of the Hamilton Group, a mixture of possible sources is required. The data suggests a mixed sediment source, with input from both Archean and Mid-Proterozoic age sources. 
Results from this study suggested greater input from a slightly older source than what has been found in previous studies. Studies from central and western New York have found $\tau_{\mathrm{DM}}$ ranging from 946-1689 Ma (Caesar et al., 2010a, 2010b). Caesar et al., (2010a, 2010b) concluded that these ages reflected sediment influx from rocks of the Canadian Shield, recycled older sedimentary units, or distal, non-North American pre-Grenville rocks, but was likely a reflection of mixing of two or more these sources. The ages reported by Caesar et al. (2010a, 2010b) could have been influenced by influx from the Acadian arc, leading to sediment mixing that would result in a drawdown of $\tau_{\mathrm{DM}}$ ages in comparison to $\tau_{\mathrm{DM}}$ ages within this study. A study from southwestern PA found $\tau_{\mathrm{DM}}$ ages

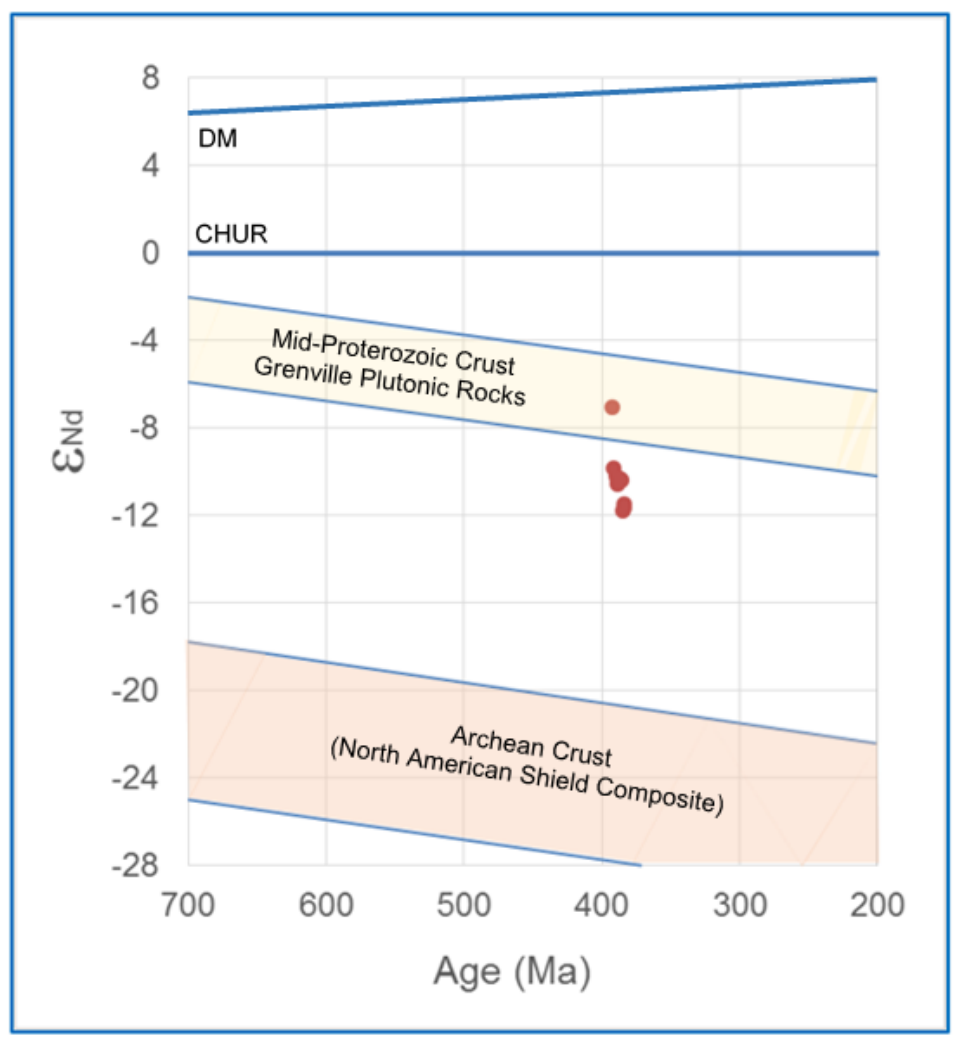

Figure 41. Graph showing the geologic age of Hamilton Group rocks versus $\varepsilon_{\mathrm{Nd}}$ values in order to show sediment mixing from both Mesoproterozoic (Grenville) and Archean (Superior Craton) aged sediment sources. Adapted from Anderson and Samson (1995) and McLennan et al. (1993). 
ranging from 1.4-1.6 Ga (Gardiner et al., 2012) within the Marcellus Shale, which fall between the ages of Archean and Mesoproterozic crust.

\subsection{Paleoclimate influence}

Climate signals are not apparent in the geochemical composition of the Hamilton Group deposits. Clay mineralogy within the Hamilton Group was fairly homogeneous and likely modified by diagenesis. Samples are dominated by illite and muscovite with minor amounts of chlorite appearing in the upper Marcellus Shale and into the Mahantango Formation (Fig 24-27). The dominance of illite and muscovite could have two possible implications: 1) The abundance and uniform frequency of illite throughout the Hamilton Group could imply contribution of illite from erosion under stable climate conditions (Chamley, 1989). 2) Alternately, illite and muscovite could have formed from decomposition of original kaolinite.

\subsection{Provenance Model and Evolution}

The geochemical and petrographic data indicate erosion of primarily felsic igneous and upper-continental crustal source, with $\mathrm{Sm}-\mathrm{Nd} \tau_{\mathrm{DM}}$ ages ranging from 1.6-1.8 Ga and negative $\varepsilon_{\text {Nd }}$ values indicating primary crustal origin of the parent source rock. Together these data are consistent with sediment influx to the basin from the old continental crust of the Superior Craton exposed to the north. Although the Superior Craton has a wide range of lithologies, it is dominated by felsic plutonic rocks of Archean age (Percival et al., 2012). However, Sm-Nd analysis requires additional sediment input from a rock bearing younger $\mathrm{Sm}-\mathrm{Nd} \tau_{\mathrm{DM}}$ ages and more positive $\varepsilon_{\mathrm{Nd}}$ values. Rocks of the 
Acadian fold-thrust belt have slightly younger $\mathrm{Sm}-\mathrm{Nd} \tau_{\mathrm{DM}}$ ages $(\sim 1.0-1.3 \mathrm{Ga}$; Fisher $e t$ al., 2010). Provenance of the units within the Acadian fold-thrust belt is dominated by Grenville terrane (Anderson and Samson, 1995; Thomas et al., 2014; Scott et al., 2016). Erosion of the Acadian fold-thrust belt produced a recycled sedimentary source signature.

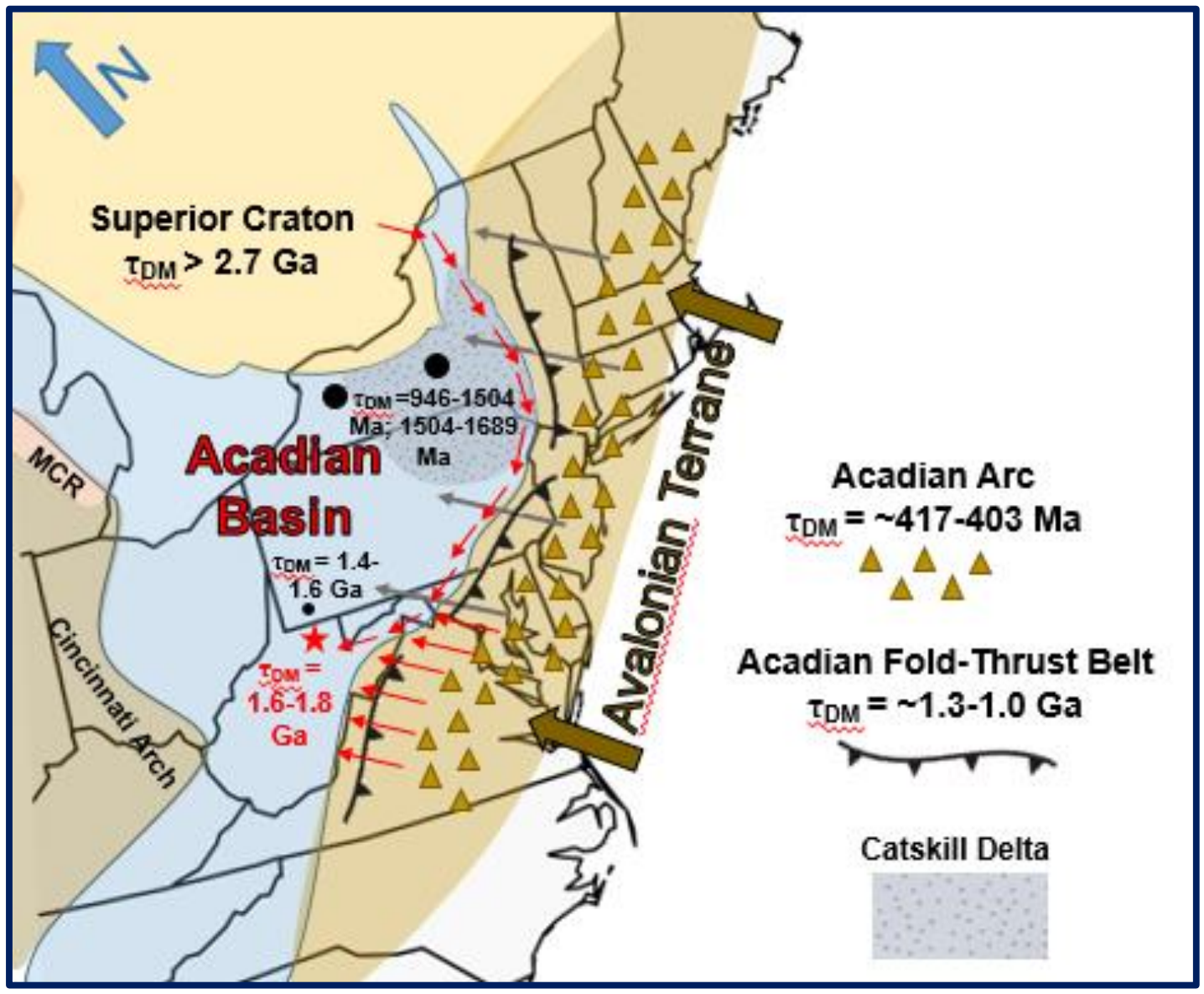

Figure 42. Map of the Middle Devonian Acadian Basin and location of provenance terranes including the Superior Craton, Acadian arc, and Acadian fold-thrust belt along with geochronologic ages. Black dots indicate the approximate location of previous studies and $\mathrm{Nd}$ depleted mantle model ages yielded from those studies. Larger black dots indicate more than one study conducted in the area. The red star and associated $\tau_{\mathrm{DM}}$ age represents the results of this study. Gray arrows indicate the approximate wind direction as interpreted from the distribution of Tioga Ashes within the Acadian Basin. Red arrows show how detrital clay sediments were generally transported to the central Acadian Basin. Note how Nd depleted mantle model ages are older the farther from the Catskill Delta. MCR=Mid-continent rift. Data compiled from Blakey, 2009; Caesar et al., 2010a, 2010b; Gardiner et al., 2012; Fisher et al., 2010; Schoonmaker et al., 2011. 
Synthesis of petrological, mineralogical and geochemical data indicates variable volumes of sediment influx from northern and eastern sources controlling the lithologies of the Hamilton Group in north-central WV. In particular, Sm-Nd depleted model ages of the Hamilton Group requires mixing of older material from the Superior craton with younger material of the Acadian fold-thrust belt. The younger $\tau_{\mathrm{DM}}$ ages of the Mahantango Formation compared to the older samples in the Marcellus Shale indicate the flux of sediment derived from the Acadian fold-thrust belt increased over time (Fig 4345). A one-dimensional mixing model using $1.25 \mathrm{Ga}$ as representative $\tau_{\mathrm{DM}}$ for the Grenville-dominated thrust belt (Tollo et al., 2004) and 2.8 Ga for the Superior Craton (Fisher et al., 2010; Jaupart et al., 2014) has helped to further constrain mixed provenance evolution throughout the deposition of the Hamilton Group (Figure 43; Table 5). The model indicates that the mixture of sources transitioned from approximately $65 \%$ Acadian fold-thrust belt and 35\% Superior Craton for deposits at the bottom of the Marcellus Shale, to $75 \%$ influx from the Acadian fold-thrust belt and 25\% sediment influx from the Superior Craton at the top of the Mahantango Formation. Increasingly younger depleted mantle model ages coincide with both higher $\mathrm{Zr}$ and $\mathrm{TiO}_{2}$ concentrations in Hamilton Group mudrocks (Fig. 44-45). These trends supported the interpretation of greater sediment influx from erosion of sedimentary rocks with younger Sm-Nd ages in the adjacent Acadian fold-thrust belt over time. Mineralogical trends further support increased influx from the Acadian fold-thrust belt. Chlorite appears within the upper Marcellus Shale and increases up-section into the Mahantango Formation, but is completely absent from the middle and lower Marcellus Shale of the sampled section, suggesting this is a primary extrabasinal mineral phase (Fig. 23). Appearance of chlorite 
could further support the interpretation of sediment influx from metasedimentary rocks incorporated in Acadian thrust-sheets. Chlorite could also be representative of hydrothermal alteration of muscovite, influenced by Mg-rich brines that have been noted within the Marcellus Shale (Haluszczak et al., 2013). However, it is unlikely that Mg-rich brines would only drive chlorite formation in the upper part of the formation and not affect muscovite buried just 10's of feet deeper within the section.

Oblique collision of the micro-continent Avalonia with the eastern margin of Laurentia began with initial contact with the St. Lawrence Promontory in northern New

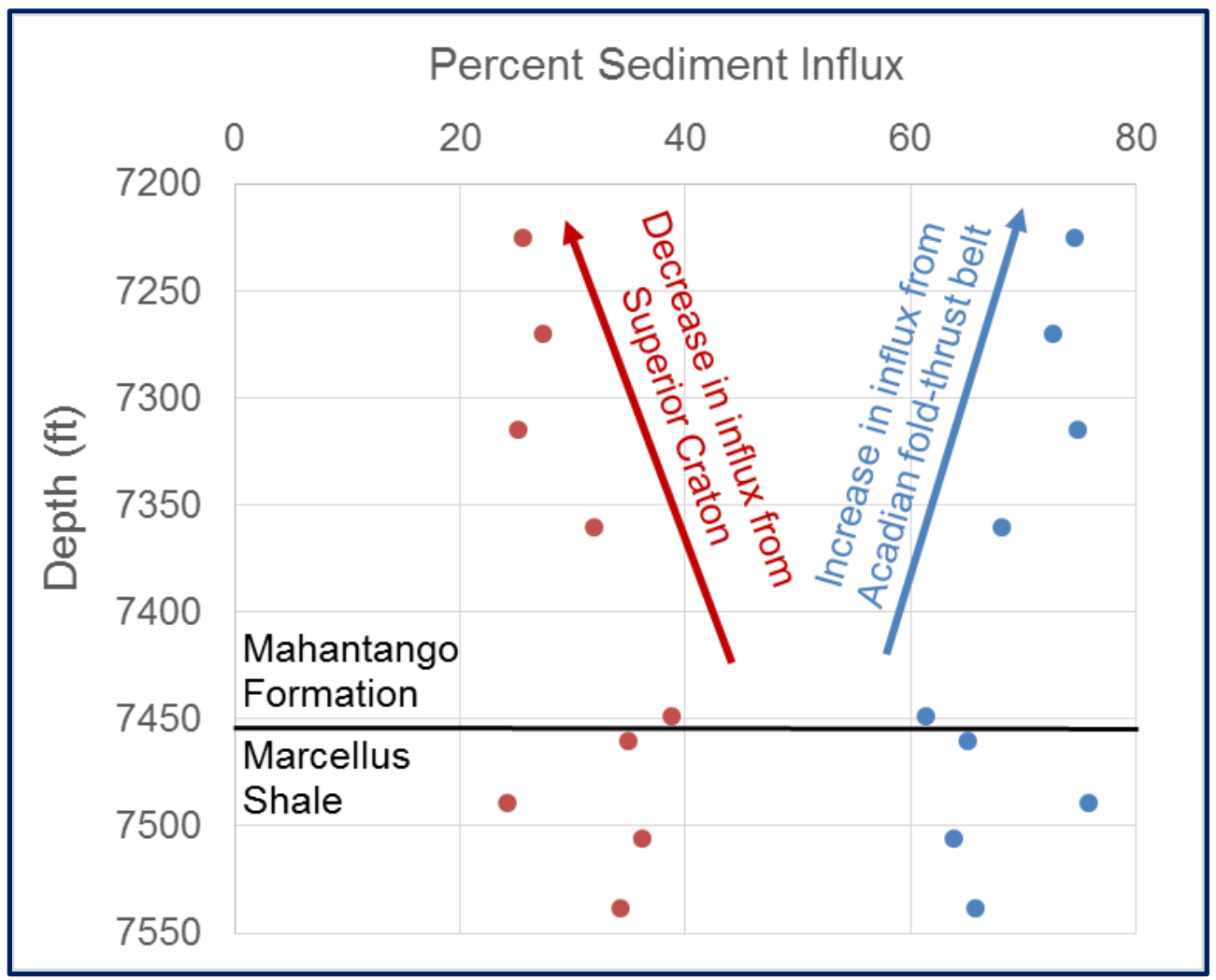

Figure 43. Graph showing the fluctuations in the mixing of sediment influx from both the Superior Craton and the Acadian fold-thrust belt. Note the increased influence from the Acadian fold-thrust belt, throughout the deposition of the Mahantango Formation. 
Table 5. Results of the one-dimensional mixing model showing the proportion of sediment influx coming from the Acadian fold-thrust belt and Superior Craton throughout the deposition of the Hamilton Group.

\begin{tabular}{ccccc}
\hline Depth (ft) & $\boldsymbol{E}_{\text {Nd }}$ & $\boldsymbol{\tau}_{\text {DM }}$ & $\begin{array}{c}\text { \% Fold- } \\
\text { Thrust Belt }\end{array}$ & $\begin{array}{c}\text { \% Superior } \\
\text { Craton }\end{array}$ \\
\hline $\mathbf{7 2 2 5 . 3}$ & -11.65 & 1.65 & 74.49 & 25.51 \\
$\mathbf{7 2 7 0 . 3}$ & -11.47 & 1.67 & 72.62 & 27.38 \\
$\mathbf{7 3 1 4 . 7}$ & -11.74 & 1.64 & 74.83 & 25.17 \\
$\mathbf{7 3 6 0 . 5}$ & -10.38 & 1.74 & 68.11 & 31.89 \\
$\mathbf{7 4 4 8 . 3 5}$ & -10.34 & 1.85 & 61.29 & 38.71 \\
$\mathbf{7 4 6 0 . 2 0}$ & -10.51 & 1.79 & 65.09 & 34.91 \\
$\mathbf{7 4 8 9 . 0 6}$ & -10.55 & 1.63 & 75.75 & 24.25 \\
$\mathbf{7 5 0 5 . 9 3}$ & -10.18 & 1.81 & 63.83 & 36.17 \\
$\mathbf{7 5 3 8 . 1 5}$ & -9.85 & 1.78 & 65.73 & 34.27 \\
\hline
\end{tabular}

England and southeastern Canada and gradually progressed southward (Ettensohn, 1985). Initial deposition of the Marcellus Shale was greater influenced by intrabasinal sediments, with limited detrital clay influx eroded and transported from the Superior Craton to the north. Sediment was transported longitudinally southward along the eastern coast of the basin. At this time, Avalonia was colliding with the New York Promontory, allowing for increased clay influx from the adjacent fold-thrust belt to be deposited into the Catskill Delta region, thus contributing to a sediment mixture that would yield younger Nd depleted mantle model ages than found within the Superior Craton and less negative $\varepsilon_{\mathrm{Nd}}$ values in the Marcellus Shale in north-central WV, similar to what was observed in Marcellus Shale samples New York (Caesar et al., 2010a, 2010b). As collision continued southward into the Virginia Promontory, the Mahantango Formation was deposited, with increased sedimentation from the adjacent Acadian fold-thrust belt to the east and greater contribution of Acadian-derived deposits caused even younger $\mathrm{Nd}$ 


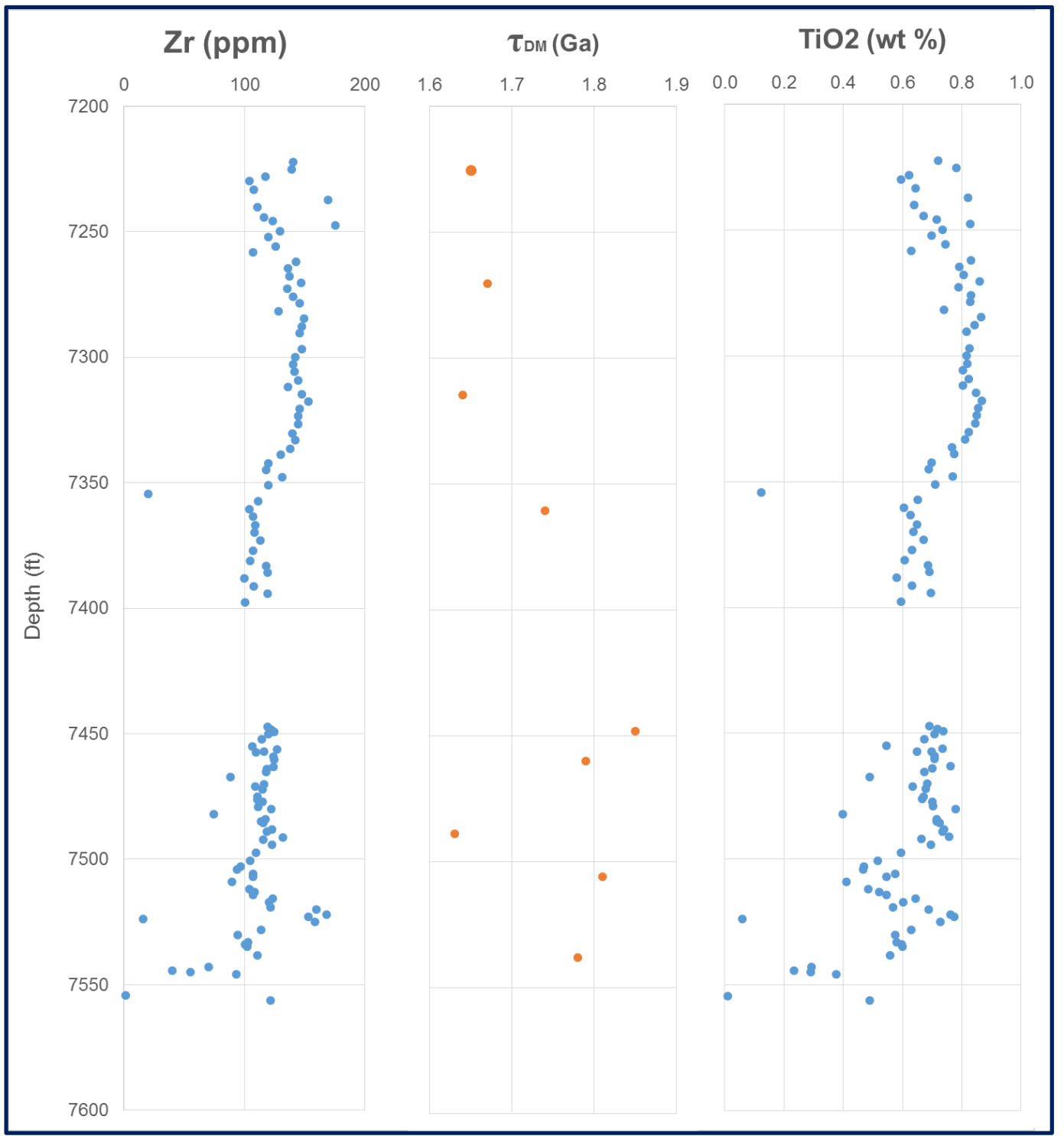

Figure 44. Concentrations of $\mathrm{Zr}(\mathrm{ppm})$ and $\mathrm{TiO}_{2}$ (wt \%) in comparison to the depleted mantle model ages $\left(\tau_{\mathrm{DM}}\right)$. Note that younger $\mathrm{Sm}-\mathrm{Nd}$ model ages occur more frequently where there are high concentrations of $\mathrm{Zr}$ and $\mathrm{Ti}$ which are signatures of influx from a recycled sedimentary source and housed within heavy minerals such as zircon and rutile. 


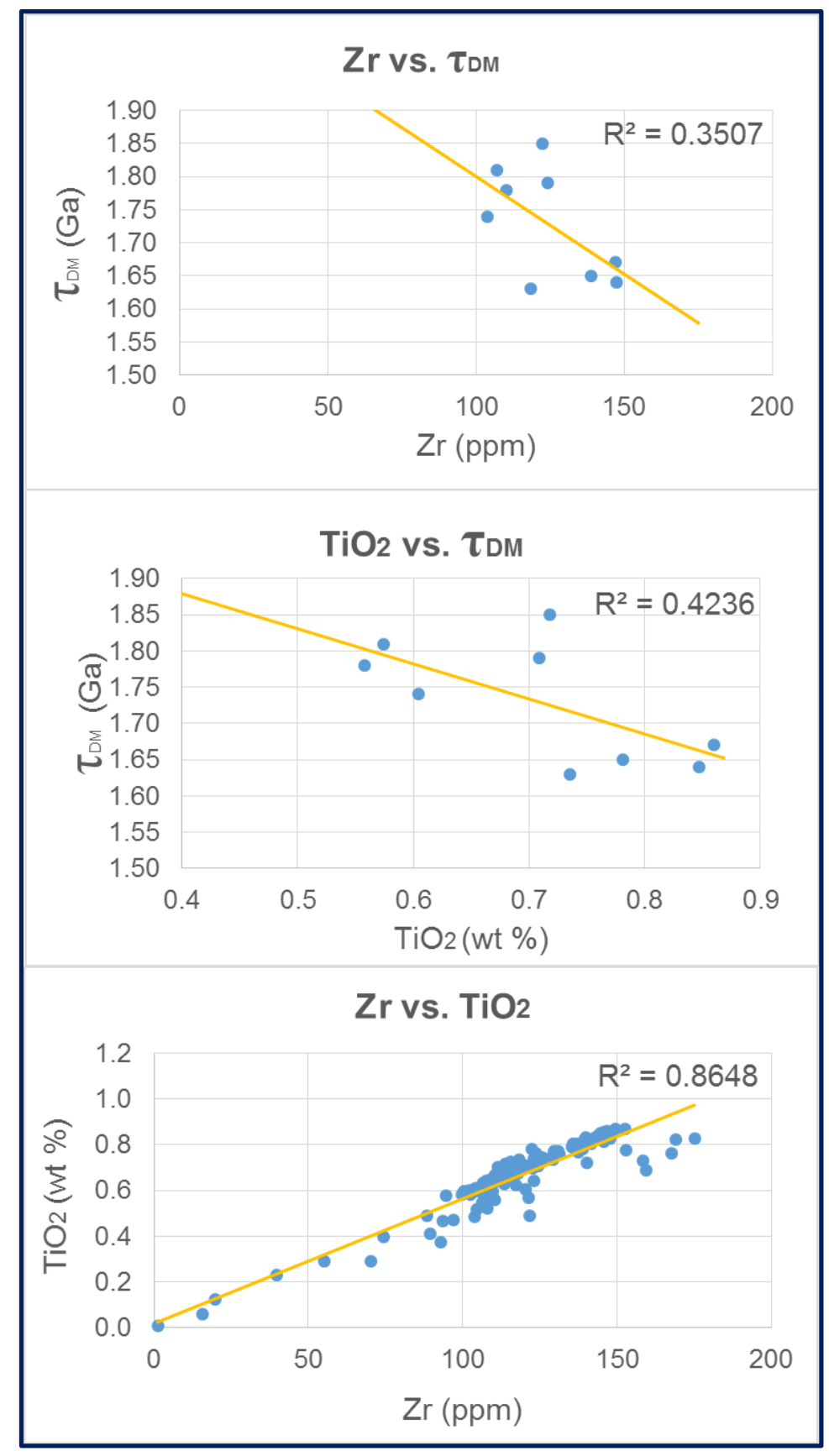

Figure 45. Cross-plots showing the relationships between $\mathrm{Zr}, \mathrm{TiO}_{2}$, and $\tau_{\mathrm{DM}}$. Note the negative correlations between both $\mathrm{Zr}$ and $\mathrm{TiO}_{2}$ versus $\tau_{\mathrm{DM}}$, further supporting the correlation between younger depleted mantle model ages and increased influx from a recycled sedimentary source. The strong correlation between $\mathrm{Zr}$ and $\mathrm{TiO}_{2}$ further support that these chemical signatures are influenced by the same sink mechanism. 
depleted mantle model ages and less negative $\varepsilon_{\mathrm{Nd}}$ in the Mahantango Formation. Ver Straeten (2010) explains the influx of coarser detrital sediment within the upper Middle Devonian shales of New York as being due to overfilling of proximal margin deposition, resulting in deltaic progradation into the basin and deposition of the detrital clays and silt. Alternately, structural advance of the Acadian thrust-front could have caused deltaic progradation to deliver greater flux of Acadian-derived material to north-central WV.

Previous interpretations of the Acadian foreland basin model relied on the assumption that clastic influx to the basin was dominantly from the adjacent fold-thrust belt with potential contribution from the unroofing of the Acadian volcanic arc. Influx from the Acadian arc would cause a drawdown in $\tau_{\mathrm{DM}}$ and also be apparent within elemental discrimination diagrams. However, results from this work show that there was greater influx from the Archean crust to the north likely transported via the Catskill delta system. Smaller transverse deltaic systems contributed sediment from the Acadian foldthrust belt that mixed in the basin with sediment from the Catskill system.

\subsection{Provenance, paleoclimate, and controls on organic-matter preservation}

Results suggested that the differences in organic-matter preservation between the Marcellus Shale and Mahantango Formation is due to dilution of organic matter, initially due to detrital clay sedimentation, and later by silt sedimentation. Although there was an increase in global temperatures throughout the deposition of the Mahantango Formation, evidence of this climatic transition is not evident within the provenance signatures interpreted by this study. It is likely that the increase in influx of clay to the basin is not primarily climate driven, but rather representative of increased tectonic influence and 
related physical weathering of source rocks during this time, resulting in increased sediment influx from the Acadian fold-thrust belt.

Comparisons of elemental data to TOC further support the story of dilution. A positive correlation between $\mathrm{Si} / \mathrm{Al}$ and $\mathrm{TOC}\left(\mathrm{R}^{2}=0.4477\right.$; Fig. 29$)$ indicates that greater clay influx to the basin resulted in less organic matter being preserved. Additionally, a negative correlation between $\mathrm{Zr}$ and TOC $\left(\mathrm{R}^{2}=0.3687\right.$; Fig. 30$)$ further supports the relationship between the provenance model previously described and dilution of organic matter content. Greater deposition from the Acadian fold-thrust belt, as indicated by the increases in $\mathrm{Zr}$, resulted in lower TOC concentrations. Petrographic trends showing a transition from the organic-rich argillaceous sarls of the lower Marcellus Shale into the tarly claystones and silty tarly claystones of the upper Marcellus Shale and Mahantango Formation help to provide visual evidence of the dilution of organic matter throughout the Hamilton Group. In summary, geochemical and petrographic evidence suggest that organic-matter content within the Hamilton Group was primarily controlled by dilution via terrigenous clastic sedimentation. This sedimentation was initially dominated by abundant clay deposition, followed by silt deposition throughout the deposition of the Hamilton Group. 


\section{CONCLUSIONS}

Geochemical and petrographic provenance indicators suggest that the Marcellus Shale and Mahantango Formation were sourced from a mix of the northern Archean Superior Craton and Grenville-sourced sediments of the Acadian fold-thrust belt to the east. Recycled sediment influx from the adjacent fold-thrust belt increased throughout the deposition of the Hamilton Group as indicated by Sm-Nd depleted mantle model ages, mineralogy, and trace element geochemistry. Differences in organic content between these two units is due to dilution of organic matter by influx of detrital clay sedimentation followed by coarser silt deposition and lower rates of organic production throughout the accumulation of the Mahantango Formation. Increased clay influx to the basin does not appear to be climate driven, but rather appears to be indicative of increased physical weathering related to evolving tectonic activity and fluvial progradation during the Acadian Orogeny. Results of this study alter the previously assumed Acadian foreland basin depositional model for the Marcellus Shale by suggesting greater influx from older upper-continental crustal sources from the north, likely transported by the Catskill Delta

river system. Investigation of provenance and paleoclimate signals through geochemical and petrographic analysis of the Hamilton Group have helped to further constrain our understanding of Acadian basin-fill architecture and the controls on organic-rich versus clay-rich facies within mudrock-dominated foreland basin systems. 


\section{REFERENCES}

Anderson, C.B., and Samson, S.D., 1995, Temporal changes in Nd isotopic composition of sedimentary rocks in the Sevier and Taconic foreland basins: Increasing influence of juvenile sources: Geology, v. 23, p. 983-986

Arthur, M.A., and Sageman, B.B., 2005, Sea-level control on source-rock development: Perspectives from the Holocene Black Sea, the Mid-Cretaceous Western Interior Basin of North America, and the Late Devonian Appalachian Basin: The Deposition of Organic-Carbon-Rich Sediments: Models, Mechanisms, and Consequences: SEPM Special Publication No. 82, p.35-59

Baioumy, H.M., 2004, Clay mineralogy of Upper Cretaceous-Lower Tertiary in Egypt and its Paleoclimatic Implications: Clay Science, v. 12, p. 223-234

Blakey, R., 2009, Middle Devonian North American Paleogeographic Map, accessed Jan. 2016

Bock, B., McLennan, S.M., and Hanson, G.N., 1994, Rare earth element redistribution and its effects on the neodymium isotopes system in the Austin Glen Member of the Normanskill Formation, New York, USA: Geochimica et Cosmochimica Acta, v. 58, p. 5245-5253

Caesar, W., Mosher, D., Regan, S.P., Cousens, B.L., Aspler, L.B., Chiarenzelli, J., and Chiarenzelli, J.R., 2010a, Nd model ages and geochemistry of Devonian and Ordovician shales of western and central New York: Geological Society of America- Abstracts with Programs, v. 42, i. 1, p. 71-72

Caesar, W., Mosher, D., Murphy, J.T. Jr., and Chiarenzelli, J.R., 2010b, Nd TDM model ages of Upper and Middle Devonian and shales of western and central New York: Geological Society of America- Abstracts with Programs, v. 42, i. 5, p. 288

Canil, D., 2008, Canada's craton: A bottoms-up view: GSA Today, v. 18, p.4-10

Chamley, H., 1989, Clay Sedimentology: Berlin, Springer-Verlag, 623 p.

Chen, R., 2016, Dominant controls on organic-rich shale deposition: Geochemical evidences from the Marcellus Shale in the Appalachian Basin: Doctoral Dissertation, West Virginia University, 130 p.

Cleaves, E.T., Edwards, J., Jr., and Glaser, J.D., 1968, Geologic Map of Maryland: Geological Survey, Baltimore, Maryland, scale 1:250,000

Cox, R., Lowe, D.R., and Cullers, R.L., 1995, The influence of sediment recycling and basement composition on evolution of mudrock chemistry in Southwestern United States: Geochimica et Cosmochimica Acta, v. 59, p. 2919-2940 
Dennison, J.M. and Hasson, K.O., 1976, Stratigraphic Cross-section of Hamilton Group (Devonian) and Adjacent Strata along South Border of Pennsylvania: The American Association of Petroleum Geologists Bulletin, v. 60, p. 278-298

Dennison, J.M., and Textoris, D.A., 1988, Devonian Tioga ash beds: Circular-West Virginia Geological and Economic Survey, p. 15-16

DePaolo, D.J., and Wasserburg, G.J., 1976, Nd Isotopic Variations and Petrogenetic Models: Geophysical Research Letters, v. 3, p. 249-252

DePaolo, D.J., 1988, Neodymium Isotope Geochemistry, and Introduction: Berlin Springer-Vaerlag., $187 \mathrm{p}$.

Dickin, A.P., 1995, Radiogenic Isotope Geochemistry: Cambridge University Press, $509 \mathrm{p}$.

Dickinson, W.R., Beard, L.S., Brakenridge, G.R., Erjavec, L.J., Ferguson, R.C., Inman, K.F., Knepp, R.A., Lindberg, F.A., and Ryberg, P.T., 1983, Provenance of North American Phanerozoic sandstones in relation to tectonic setting: Geological Society of America Bulletin v. 94, p. 222-235

Emmanuel, O.O., 2013. Geologic characterization and the recognition of cyclicity in the Middle Devonian Marcellus Shale, Appalachian Basin, NE USA: Doctorial Dissertation, Colorado School of Mines, 297 p.

Enomoto, C.B., Olea, R.A., and Coleman, J.L. Jr., 2014, Characterization of the Marcellus Shale based on computer-assisted correlations of wireline logs in Virginia and West Virginia: US Geological Survey-Scientific Investigations Report, $21 \mathrm{p}$.

Ettensohn, F.R., 1985, The Catskill Delta complex and the Acadian Orogeny; a model: Geological Society of America Special Paper No. 201, p. 39-50

Ettensohn, F.R., 2011, Acadian/Neoacadian tectonic framework of DevonianMississippian sedimentation in the Appalachian foreland basin: Geological Society of America-Abstracts with Programs, v. 43, p. 96

Ettensohn, F.R., and Lierman, T.R., 2012, The Appalachian Basin; compressional tectonic controls on the development and sedimentary infill of a composite foreland basin due to Paleozoic convergence: International Geological CongressAbstracts, v. 34, p. 854

Ettensohn, F.R., and Lierman, T.R., 2013, Large scale tectonic controls on the origin of Paleozoic dark shale source rock basins; examples from the Appalachian foreland basin, Eastern United States: American Association of Petroleum Geologists Memoir, v. 100, p. 95-124 
Fedo, C.M., Nesbitt, H.W., and Young, G.M., 1995, Unraveling the effects of potassium metasomatism in sedimentary rocks and paleosols, with implications for paleoweathering conditions and provenance: Geology, v. 23, p.921-924

Fisher, C.M., Loewy, S.L., Miller, C.F., Berquist, P., Van Schmus, W.R., Hatcher, R.D. Jr., Wooden, J.L., and Fullagar, P.D., 2010, Whole-rock Pb and Sm-Nd isotopic constraints on the growth of southeastern Laurentia during Grenvillian orogenesis: GSA Bulletin, v. 122, p. 1646-1659

Gardiner, J.B., Stewart, B.W., Capo, C., Phan, T.T., Sharma, S., Toro, J., 2012, A neodymium isotope investigation of sediment sources for the Middle Devonian Marcellus Formation, Pennsylvania, USA: Geological Society of AmericaAbstracts with Program, v. 44, i. 7, pp.314-315

Haluszczak, L.O., Rose, A.W., and Kump, L.R., 2013, Geochemical evaluation of flowback brine from Marcellus gas wells in Pennsylvania, USA: Applied Geochemistry, v. 28, p. 55-61

Harnois, L., 1988, The CIW index; a new chemical index of weathering: Sedimentary Geology, v. 55, p. 319-322

Harper, J.A., and Piotrowski, R.G., 1978, Stratigraphy, extent, gas production, and future has potential of the Devonian organic-rich shales in Pennsylvania: DOE/METC Eastern Gas Shales Symposium, p.310-329

Harris, A.G., Stamm, N.R., Weary, D.J., Repetski, J.E., Stamm, R.G., and Parker, R.A., 1994, Conodont color alteration index (CAI) map and conodont-based age determinations for the Winchester 30'x60' quadrangle and adjacent area, Virginia, West Virginia, and Maryland: US Geological Survey Miscellaneous Field Studies Map, MF-2239, 1 sheet, 40 p., scale 1:100,000

Hayward, J.M., 2012, Zircon geochronology of ash beds in the Marcellus Shale of the Appalachian basin: Master's Thesis, West Virginia University, 96 p.

Hibbard, J.P., van Staal, C.R., and Rankin, D.W., 2010, Comparative analysis of the geological evolution of the northern and southern Appalachian orogeny Late Ordovician-Permian: Geological Society of America Memoir, v. 206, p. 51-69

Jaupart, C., Mareschal, J.C., Bouquerel, H., and Phaneuf, C., 2014, The building and stabilization of an Archean Craton in the Superior Province, Canada, from a heat flow perspective: Journal of Geophysical Research: Solid Earth, v. 119, p. 91309155 
Joachimski, M.M., Breisig, S., Buggisch, W., Talent, J.A., Mawson, R., Gereke, M., Morrow, J.R., Day, J., and Weddige, K., 2009, Devonian climate and reef evolution: Insights from oxygen isotopes in apatite: Earth and Planetary Science Letters, v. 284, pp. 599-609

Johnson, J.G., 1974, Shorelines of eperic seas: American Journal of Science, v. 274, p. $465-470$

Lash, G.G., and Engelder, T., 2011, Thickness trends and sequence stratigraphy of the Middle Devonian Marcellus Formation, Appalachian Basin: Implications for Acadian foreland basin evolution: American Association of Petroleum Geologists Bulletin, v. 95, i. 1, pp. 61-103

Lee, Y.I., 2002, Provenance derived from the geochemistry of late Paleozoic-early Mesozoic mudrocks of the Pyeongan Supergroup, Korea: Sedimentary Geology, v. 149 , p. $219-235$

Ma, P., Wang, L., Wang, C., Wu, X., Wei, Y., 2015, Organic-matter acculation of the lacustrine Lunpola oil shale, central Tibetan Plateau: Controlled by the paleoclimate, provenance, and drainage system: International Journal of Coal Geology, v. 147-148, p.58-70

McKerrow, W.S., and Scotese, C.R., 1990, alaeozoic Palaeogeography and Biogeoraphy: Geological Society of London Memoir No.12, 431 p.

McLennan, S.M., Taylor, M.T., McCulloch, M.T., and Maynard, J.B., 1990, Geochemical and Nd-Sm isotopic composition of deep-sea turbidites: Crustal evolution and plate tectonic associations: Geochimica et Cosmochimica Acta, v. 54 , p. 2015-2050

McLennan, S.M, Hemming, S., McDaniel, D.K., and Hanson, G.N., 1993, Geochemical approaches to sedimentation, provenance, and tectonics in Johnsson, M.J., and Basu, A., eds., Processes Controlling the Composition of Clastic Sediments: Boulder, Colorado, Geological Society of America Special Paper 284, p. 21-40

Milici, R.C., and Swezey, C.S., 2014, Assessment of Appalachian basin oil and gas resources; Devonian gas shales of the Devonian Shale-Middle and Upper Paleozoic Total Petroleum System: U.S. Geological Survey Professional Paper $1708,81 \mathrm{p}$.

Milliken, K.L., Day-Stirrat, R.J., Papazis, P.K., and Dohse, C., 2012, Carbonate lithologies of the Mississippian Barnett Shale, Fort Worth Basin, Texas, in H.A. Breyer, ed., Shale reservoirs-Giant resources for the $21^{\text {st }}$ century: AAPG Memoir 97, p. 290-321 
Milliken, K., 2014, A compositional classification for grain assemblages in fine-grained sediments and sedimentary rocks: Journal of Sedimentary Research, v. 84, p. 1185-1199

Morshed. S.M., and Tatham, R.H., 2013, Rock physics modeling to constrain petrophysical properties in the productive zone of the Marcellus Shale, WV from wireline log data: American Geophysical Union Fall Meeting

Mosher, D., Caesar, W., O’Brien, N.R., Leone, J., and Chiarenzelli, J.R., 2010, Geochemical and isotopic characterization of potential gas bearing units of the Utica and Marcellus Shale, New York: Geological Society of America- Abstracts with Programs, v. 42, i. 1, p. 63

MSEEL, 2015, Marcellus Shale Energy and Environmental Laboratory (MSEEL): http://mseel.org/ (accessed January 2017)

Murphy, A.E., Sageman, B.B., and Hollander, D.J., 2000, Black shale deposition and faunal overturn in the Devonian Appalachian basin: clastic starvation, seasonal water-column mixing, and efficient biolimiting nutrient recycling:

Paleoceanography, v. 15, p. 280-291

Nesbitt, H.W., and Young, G.M., 1984, Prediction of some weathering trends of plutonic and volcanic rocks based on thermodynamic and kinetic considerations:

Geochimica et Cosomochimica Acta, v. 48, p. 1523-1534

Nesbitt, H.W., and Young, G.M., 1989, Formation and diagenesis of weathering profiles: The Journal of Geology, v. 97, p. 129-147

Paronish, T., 2017, Meso- and macro-scale facies and chemostratigraphic analysis of Middle Devonian Marcellus Shale in northern West Virginia, USA: Master's Thesis, West Virginia University

Parrish, C.B., 2013, Insights into the Appalachian Basin Middle Devonian Depositional System from U-Pb Zircon Geochronology of Volcanic Ashes in the Marcellus Shales and Onondaga Limestone: Master's Thesis, West Virginia University, 149 p.

Pedersen, T.F., and Calvert, S.E., 1990, Anoxia vs. Productivity: What controls the formation of organic-carbon-rich sediments and sedimentary rocks?: American Association of Petroleum Geologists Bulletin, v. 74, p. 454-466

Percival, J.A., Sanborn-Barries, M., Skulski, T., Stott, G.M., Helmstaedt, H., and White, D.J., 2006, Tectonic evolution of the western Superior Province from NATMAP and Lithoprobe studies: Canadian Journal of Earth Sciences, v. 43, p.1085-1117 
Percival, J.A., Skulski, T., Sanborn-Barrie, M., Stott, G.M., Leclair, A.D., Corkery, M.T., and Boily, M., 2012, Geology and tectonic evolution of the Superior Province, Canada: Chapter 6 in Tectonic Styles in Canada: The Lithoprobe Perspective, eds. Percival, J.A., Cook, F.A., and Clowes, R.M.: Geological Association of Cananda Special Paper 49, p.321-378

Picard, M.D., Classification of fine-grained sedimentary rocks: Journal of Sedimentary Petrology, v. 41, p. 179-195

Pin, C. and Zalduegui, J.S., 1997, Sequential separation of light rare-earth elements, thorium and uranium by miniaturized extraction chromatography: application to isotopic analyses of silicate rocks: Analytica Chimica Acta, v. 339, p.79-89.

Potter, P.E., Maynard, J.B., and Depetris, P.J., 2005, Chapter 7, Provenance of Mudstones: Mud and Mudstones, Introduction and Overview: Berlin, Springer, p. $157-174$

Repetski, J.E., Over, J.D., and Enomoto, C.B., 2013, Conodont-based correlation of the Marcellus/Millboro formations in the Central Appalachian Basin: The Geological Society of America- Abstracts with Programs, v. 45, p. 529

Richard, P., Schimizu, N., and Allegre, C.J., 1976, ${ }^{143} \mathrm{Nd} /{ }^{146} \mathrm{Nd}$ a natural tracer: an application to oceanic basalts: Earth and Planetary Sciences Letters, v. 31, p.269278.

Roen, J.B., and Hosterman, J.W., 1982, Misuse of the term "bentonite" for ash beds of Devonian age in the Appalachian basin: Geological Society of America Bulletin, v. 93 , p. 921-925

Roser, B.P., and Korsch, R.J., 1988, Provenance signatures of sandstone-mudstone suites determined using discriminant function analysis of major-element data: Chemical Geology, v. 67, p. 119-139

Sageman, B.B., Murphy, A.E., Werne, J.P., Ver Straeten, C.A., Hollander, D.J., and Lyons, T.W., 2003, A tale of shales: the relative roles of production, decomposition, and dilution in the accumulation of organic-rich strata, MiddleUpper Devonian, Appalachian basin: Chemical Geology, v. 195, p. 229-273

Sak, P.B., McQuarrie, N., Oliver, B.P., Lavdovsky, N., and Jackson, M.S., 2012, Unraveling the central Appalachian fold-thrust belt, Pennsylvania: The power of sequentially restored balanced cross-sections for a blind fold-thrust belt: Geosphere, v. 8, p.1-18 
Scott, B.E., Garver, J.I., and Kidd, W.S.F., 2016, Provenance of detrital zircon in Taconic Foreland flysch, in the Hudson and Mohawk Valleys of eastern New York: Geological Society of America-Abstracts with Programs, v. 48, no. 30-7

Selleck, B.W., Chiarenzelli, J., Kratzmann, D.J., Christoffersen, P., and Durham, A., 2014, Detrital zircon geochronology and provenance of Middle and Upper Devonian strata, norther Appalachian Basin of New York State: Geological Society of America- Abstracts with Programs, v. 46, i. 2, p. 98

Selleck, B., Ver Straeten, C., Chiarenzelli, J.R., and Holzman, E., 2016, Provenance evolution during assembly of the Acadian/Neoacadian Orogen: Detrital zircon data from the Devonian of New York: Geological Society of America-Abstracts with Programs, v. 48, paper no. 30-10

Simon, L., Goddéris, Y., Buggisch, W., Strauss, H., and Joachimski, M.M., 2007, Modeling the carbon and sulfur isotopes compositions of marine sediments: Climate evolution during the Devonian: Chemical Geology, v. 246, pp.19-38

Sinha, A.K., Thomas, W.A., and Hatcher, R.D., 2010, Ordovician to Devonian magmatism associated with Taconic collisional tectonics in the Central Appalachians; an example of an orogenic cycle: Geological Society of AmericaAbstracts with Programs, v. 42.1, p. 98

Schoonmaker, A., Kidd, W.S.F., Reusch, D.N., Dorais, M.J., Gregg, T., and Spencer, C., 2011, Stratigraphic context, geochemical, and isotopic properties of magmatism in the Siluro-Devonian inliers of northern Maine: Implications for the Acadian Orogeny

Soeder, D.J., Enomoto, C.B., and Cermak, J.A., 2014, The Devonian Marcellus Shale and Millboro Shale: The Geological Society of America Field Guide 35, p. 129-160

Thomas, W.A., Mueller, P.A., and Gehrels, G.E., 2014, Detrital-zircon record of provenance of Ordovician-Devonian sandstones in the Appalachian Foreland: Geological Society of America-Abstracts with Program, v. 46

Tucker, R.D., Bradley, D.C., Ver Straeten, C.A., Harris, A.G., Ebert, J.R., and McCutcheon, S.R., 1998, New U-Pb zircon ages and the duration and division of Devonian time: Earth and Planetary Science Letters, V. 158, p.175-186

van Staal, C.R., Whalen, J.B., Valverde-Vaquero, P., Zagorevski, A., Rogers, N., 2009, Pre-Carboniferous, episodic accretion-related, orogenesis along the Laurentian margin of the Northern Appalachians: Geological Society of London-Special Publications, v. 327, p. 271-316 
van Staal, C.R., Barr, S.M., Whalen, J.B., and White, C.E., 2011, Constraints on the tectonic setting of Devonian magmatism and orogenesis: Geological Society of America, Abstracts with Programs, v. 43, p.158

Ver Straeten, 1995, Stratigraphic Synthesis and Tectonic and Sequence Stratigraphic framework, upper Lower and Middle Devonian, Northern and Central Appalachian Basin: Doctorial Dissertation- University of Rochester, 824 p.

Ver Straeten, C.A. and Sageman, B.B., 1999a, Elemental geochemistry of Mudrocks, Middle to Upper Devonian Appalachian foreland basin; Implications for source province and Acadian unroofing: Geological Society of America-Abstracts with Programs, v. 31, i. 2, p. 76

Ver Straeten, C.A. and Sageman, B.B., 1999b, Mudrock geochemistry, Devonian Appalachian Foreland Basin: Implications for source provenance, and unroofing of the Acadian Orogeny: Geological Society of America- Abstracts with Programs, v. 31 , i. 7 , p. 375

Ver Straeten, C.A., 2002, K-bentonites, ash bed preservation, and implications for Lower to Middle Devonian volcanism, Eastern United States: Geological Society of America-Abstracts with Programs, v. 34, p. 138

Ver Straeten, C.A., 2004, K-bentonites, volcanic ash preservation, and implications for Early to Middle Devonian volcanism in the Acadian orogen, eastern North America: GSA Bulletin, v. 116, p. 474-489

Ver Straeten, C.A., 2010, Lessons from the foreland basin: Northern Appalachian basin perspectives on the Acadian orogeny: The Geological Society of America Memoir 206, p. 251-282

Wan, Z., 2012, Stable Carbon and Nitrogen Isotopic Studies of Devonian Land PlantsAn Indicator of Paleoclimate and Paleoenvironmental Changes: Doctoral Dissertation, University of Cincinnati, $156 \mathrm{p}$.

Wang, G., and Carr, T.R., 2013, Organic-rich Marcellus Shale lithofacies modeling and distribution pattern analysis in the Appalachian Basin: AAPG Bulletin, v. 97, p. 2173-2205

Yu, W., 2015, Developments in modeling and optimization of production in unconventional oil and has reservoirs: Doctoral Dissertation, University of Texas at Austin, $264 \mathrm{p}$.

Zhang, L., Sun, M., Wang, S., and Yu, X., 1998, The composition of shales from the Ordos basin, China: effects of source weathering and diagenesis: Sedimentary Geology, v. 116, p. 129-141 
Zhou, C.H., and Keeling, J., 2013, Fundamental and applied research on clay minerals: From climate and environment to nanotechnology: Applied Clay Science, p. 3-9 
APPENDIX I. Table containing mineral identification information relevant to the X'pert HighScore Plus identification system including the common name, compound name, reference code, chemical formula, and reference intensity ratio of all the mineral phases identified within the Hamilton Group.

\begin{tabular}{|c|c|c|c|c|}
\hline $\begin{array}{l}\text { Common } \\
\text { Name }\end{array}$ & $\begin{array}{l}\text { Compound } \\
\text { Name }\end{array}$ & $\begin{array}{c}\text { Reference } \\
\text { Code }\end{array}$ & Chemical Formula & $\begin{array}{c}\text { Reference } \\
\text { Intensity } \\
\text { Ratio } \\
\text { (RIR) } \\
\end{array}$ \\
\hline Albite & Albite, ordered & $\begin{array}{c}00-009- \\
0466\end{array}$ & $\mathrm{NaAlSi}_{3} \mathrm{O}_{8}$ & 2.10 \\
\hline Barite & Barite & $\begin{array}{c}01-089- \\
7357 \\
\end{array}$ & $\mathrm{BaSO}_{4}$ & 2.78 \\
\hline Calcite & Calcite & $\begin{array}{c}01-083- \\
0578 \\
\end{array}$ & $\mathrm{CaCO}_{3}$ & 3.21 \\
\hline Chlorite & $\begin{array}{l}\text { Clinochlore } \\
1 \mathrm{Mla}\end{array}$ & $\begin{array}{c}\text { 01-089- } \\
2972 \\
\end{array}$ & $\mathrm{Mg}_{2.5} \mathrm{Fe}_{1.65} \mathrm{AlO}_{10}(\mathrm{OH})_{8}$ & 1.06 \\
\hline Dolomite & $\begin{array}{l}\text { Dolomite } \\
(1687)\end{array}$ & $\begin{array}{c}01-073- \\
2409 \\
\end{array}$ & $\mathrm{CaMg}\left(\mathrm{CO}_{3}\right)_{2}$ & 2.42 \\
\hline Gypsum & Gypsum, syn & $\begin{array}{c}00-033- \\
0311 \\
\end{array}$ & $\mathrm{CaSO}_{4} \cdot 2 \mathrm{H}_{2} \mathrm{O}$ & 1.83 \\
\hline Muscovite & $\begin{array}{l}\text { Muscovite } \\
\text { 2\ITM\RG\#1 }\end{array}$ & $\begin{array}{c}01-082- \\
0576\end{array}$ & $\mathrm{KAl}_{2}(\mathrm{AlSi} 3) \mathrm{O}_{10}(\mathrm{OH})_{2}$ & 0.38 \\
\hline Pyrite & Pyrite & $\begin{array}{c}01-071- \\
1680\end{array}$ & $\mathrm{FeS}_{2}$ & 0.89 \\
\hline Quartz & Quartz, low & $\begin{array}{c}00-005- \\
0490\end{array}$ & $\mathrm{SiO}_{2}$ & 3.6 \\
\hline
\end{tabular}


APPENDIX II. RIR interpretation of bulk mineralogy for samples collected from the MIP-3H well. Samples collected from the Marcellus Shale (MS) are colored in blue, with samples from the Mahantango Formation (MF) are colored in brown.

\begin{tabular}{|c|c|c|c|c|c|c|c|c|}
\hline Depth (ft) & Quartz & Muscovite & Chlorite & Pyrite & Albite & Calcite & Dolomite & Barite \\
\hline 7447.20 & 32 & 46 & 9 & 9 & 2 & 1 & 1 & 0 \\
\hline 7448.35 & 31 & 49 & 9 & 9 & 3 & 0 & 0 & 0 \\
\hline 7449.25 & 32 & 45 & 8 & 12 & 3 & 0 & 0 & 0 \\
\hline 7450.20 & 35 & 44 & 7 & 11 & 3 & 0 & 0 & 0 \\
\hline 7451.00 & 34 & 43 & 6 & 13 & 2 & 1 & 1 & 0 \\
\hline 7452.22 & 28 & 52 & 8 & 9 & 3 & 0 & 0 & 0 \\
\hline 7455.00 & 28 & 36 & 14 & 3 & 2 & 14 & 3 & 0 \\
\hline 7456.16 & 21 & 55 & 11 & 10 & 3 & 0 & 0 & 0 \\
\hline 7457.15 & 33 & 44 & 7 & 13 & 2 & 0 & 1 & 0 \\
\hline 7459.13 & 14 & 51 & 27 & 4 & 5 & 0 & 0 & 0 \\
\hline 7460.20 & 31 & 47 & 7 & 11 & 3 & 0 & 0 & 0 \\
\hline 7463.10 & 34 & 46 & 9 & 8 & 3 & 0 & 0 & 0 \\
\hline 7464.05 & 33 & 44 & 8 & 11 & 3 & 0 & 0 & 0 \\
\hline 7465.30 & 30 & 45 & 8 & 14 & 3 & 0 & 0 & 0 \\
\hline 7467.30 & 24 & 33 & 7 & 10 & 2 & 22 & 2 & 0 \\
\hline 7470.05 & 32 & 47 & 7 & 12 & 3 & 0 & 0 & 0 \\
\hline 7471.13 & 32 & 43 & 7 & 11 & 2 & 2 & 1 & 2 \\
\hline 7472.09 & 26 & 50 & 8 & 13 & 3 & 0 & 0 & 0 \\
\hline 7475.12 & 27 & 46 & 8 & 12 & 3 & 2 & 0 & 3 \\
\hline 7476.15 & 30 & 43 & 9 & 13 & 2 & 4 & 0 & 0 \\
\hline 7477.07 & 13 & 57 & 14 & 8 & 4 & 4 & 0 & 0 \\
\hline 7479.05 & 30 & 50 & 7 & 9 & 3 & 1 & 0 & 0 \\
\hline 7480.05 & 34 & 47 & 7 & 9 & 3 & 1 & 0 & 0 \\
\hline 7482.12 & 13 & 37 & 8 & 8 & 2 & 28 & 5 & 0 \\
\hline 7484.11 & 34 & 48 & 6 & 8 & 3 & 0 & 0 & 0 \\
\hline 7485.03 & 34 & 47 & 6 & 9 & 3 & 0 & 1 & 0 \\
\hline 7485.60 & 31 & 52 & 7 & 8 & 3 & 0 & 0 & 0 \\
\hline 7488.15 & 29 & 51 & 7 & 7 & 3 & 1 & 3 & 0 \\
\hline 7489.06 & 34 & 44 & 6 & 11 & 2 & 0 & 2 & 0 \\
\hline 7491.22 & 33 & 46 & 6 & 11 & 3 & 1 & 1 & 0 \\
\hline 7492.06 & 30 & 44 & 6 & 10 & 3 & 1 & 2 & 4 \\
\hline 7494.20 & 35 & 45 & 5 & 9 & 3 & 1 & 1 & 0 \\
\hline 7497.39 & 25 & 38 & 5 & 19 & 2 & 8 & 1 & 1 \\
\hline 7500.60 & 31 & 42 & 3 & 10 & 3 & 7 & 1 & 3 \\
\hline 7503.04 & 36 & 47 & 0 & 10 & 2 & 3 & 2 & 0 \\
\hline 7505.93 & 34 & 45 & 0 & 16 & 3 & 1 & 1 & 0 \\
\hline 7506.99 & 30 & 55 & 0 & 8 & 3 & 2 & 1 & 0 \\
\hline 7509.01 & 31 & 39 & 0 & 16 & 2 & 11 & 1 & \\
\hline 7512.01 & 37 & 45 & 0 & 13 & 3 & 1 & 1 & 0 \\
\hline
\end{tabular}




\begin{tabular}{lllllllll}
$\mathbf{7 5 1 3 . 0 8}$ & 19 & 60 & 0 & 6 & 6 & 4 & 6 & 0 \\
$\mathbf{7 5 1 4 . 1 0}$ & 38 & 43 & 0 & 13 & 2 & 3 & 1 & 0 \\
$\mathbf{7 5 1 5 . 8 0}$ & 28 & 49 & 0 & 11 & 3 & 8 & 1 & 0 \\
$\mathbf{7 5 1 7 . 2 3}$ & 35 & 41 & 0 & 11 & 3 & 9 & 1 & 0 \\
$\mathbf{7 5 1 9 . 0 5}$ & 27 & 40 & 0 & 19 & 3 & 6 & 2 & 4 \\
$\mathbf{7 5 2 0 . 1 3}$ & 33 & 41 & 0 & 9 & 3 & 3 & 3 & 0 \\
$\mathbf{7 5 2 2 . 0 5}$ & 34 & 50 & 0 & 8 & 3 & 4 & 1 & 0 \\
$\mathbf{7 5 2 3 . 0 3}$ & 34 & 51 & 0 & 4 & 3 & 8 & 1 & 0 \\
$\mathbf{7 5 2 3 . 8 9}$ & 4 & 0 & 0 & 5 & 5 & 79 & 0 & 8 \\
$\mathbf{7 5 2 4 . 9 0}$ & 34 & 48 & 0 & 3 & 3 & 11 & 2 & 0 \\
$\mathbf{7 5 2 8 . 0 1}$ & 32 & 46 & 0 & 11 & 3 & 8 & 1 & 0 \\
$\mathbf{7 5 3 0 . 1 5}$ & 23 & 57 & 0 & 10 & 4 & 3 & 0 & 3 \\
$\mathbf{7 5 3 3 . 0 2}$ & 19 & 59 & 0 & 10 & 4 & 10 & 1 & 0 \\
$\mathbf{7 5 3 4 . 0 4}$ & 35 & 43 & 0 & 12 & 3 & 7 & 1 & 0 \\
$\mathbf{7 5 3 4 . 8 9}$ & 36 & 47 & 0 & 11 & 3 & 3 & 0 & 0 \\
$\mathbf{7 5 3 8 . 1 5}$ & 32 & 47 & 0 & 15 & 3 & 2 & 1 & 0 \\
$\mathbf{7 5 4 2 . 9 3}$ & 23 & 35 & 0 & 15 & 2 & 24 & 1 & 0 \\
$\mathbf{7 5 4 4 . 3 7}$ & 18 & 41 & 0 & 16 & 5 & 4 & 1 & 16 \\
$\mathbf{7 5 4 4 . 8 5}$ & 19 & 43 & 0 & 21 & 3 & 4 & 1 & 10 \\
$\mathbf{7 5 4 5 . 7 7}$ & 24 & 50 & 0 & 16 & 3 & 4 & 2 & 0 \\
$\mathbf{7 5 5 4 . 3 3}$ & 22 & 0 & 0 & 8 & 0 & 66 & 0 & 3 \\
$\mathbf{7 5 5 6 . 1 5}$ & 26 & 51 & 0 & 6 & 3 & 12 & 2 & 0 \\
\hline
\end{tabular}


APPENDIX III. XRF-quantified interpretation of bulk mineralogy for samples collected from the MIP-3H well. Samples collected from the Marcellus Shale (MS) are colored in blue, with samples from the Mahantango Formation (MF) are colored in brown.

\begin{tabular}{|c|c|c|c|c|c|c|c|c|}
\hline Sample & Quartz & Muscovite & Chlorite & Pyrite & Albite & Calcite & Dolomite & Barite \\
\hline 7447.20 & 48.01 & 29.09 & 7.10 & 8.86 & 5.12 & 1.21 & 0.35 & 0.25 \\
\hline 7448.35 & 47.78 & 30.34 & 7.46 & 8.66 & 4.89 & 0.68 & 0.00 & 0.20 \\
\hline 7449.25 & 45.99 & 30.36 & 7.49 & 9.95 & 5.40 & 0.57 & 0.00 & 0.23 \\
\hline 7450.20 & 48.38 & 29.32 & 7.23 & 8.80 & 5.36 & 0.69 & 0.00 & 0.21 \\
\hline 7452.22 & 49.82 & 27.98 & 6.95 & 9.21 & 5.34 & 0.48 & 0.00 & 0.20 \\
\hline 7455.00 & 32.60 & 17.51 & 9.51 & 10.17 & 2.62 & 25.62 & 1.79 & 0.18 \\
\hline 7456.16 & 42.99 & 33.52 & 7.64 & 9.20 & 5.58 & 0.79 & 0.00 & 0.28 \\
\hline 7457.15 & 46.02 & 30.90 & 6.74 & 9.59 & 5.49 & 0.91 & 0.00 & 0.36 \\
\hline 7457.37 & 48.11 & 27.62 & 7.20 & 10.23 & 5.10 & 1.56 & 0.00 & 0.18 \\
\hline 7459.13 & 42.54 & 32.37 & 8.04 & 10.62 & 5.31 & 0.83 & 0.00 & 0.28 \\
\hline 7460.20 & 43.21 & 33.47 & 8.21 & 9.04 & 5.26 & 0.54 & 0.00 & 0.27 \\
\hline 7463.10 & 44.35 & 33.21 & 7.84 & 7.94 & 5.45 & 0.69 & 0.00 & 0.52 \\
\hline 7464.05 & 42.91 & 32.93 & 7.86 & 8.35 & 5.26 & 2.42 & 0.00 & 0.28 \\
\hline 7465.30 & 43.00 & 31.71 & 7.58 & 10.35 & 5.62 & 1.05 & 0.00 & 0.69 \\
\hline 7467.30 & 31.33 & 22.74 & 5.91 & 8.56 & 3.54 & 26.21 & 1.48 & 0.23 \\
\hline 7470.05 & 44.26 & 33.44 & 7.52 & 8.25 & 5.49 & 0.78 & 0.00 & 0.25 \\
\hline 7471.13 & 43.06 & 31.54 & 6.60 & 8.84 & 5.17 & 2.88 & 0.68 & 1.24 \\
\hline 7472.09 & 42.57 & 33.57 & 7.66 & 8.72 & 5.42 & 0.69 & 0.00 & 1.36 \\
\hline 7475.12 & 40.70 & 32.20 & 7.34 & 9.22 & 5.31 & 2.18 & 0.00 & 3.04 \\
\hline 7476.15 & 40.83 & 32.75 & 7.34 & 9.44 & 5.11 & 4.26 & 0.00 & 0.27 \\
\hline 7477.07 & 40.73 & 31.66 & 7.14 & 11.86 & 4.82 & 3.55 & 0.00 & 0.23 \\
\hline 7479.05 & 44.66 & 33.14 & 7.02 & 8.06 & 5.64 & 1.23 & 0.00 & 0.26 \\
\hline 7480.05 & 45.75 & 32.75 & 7.02 & 7.49 & 5.68 & 1.00 & 0.00 & 0.32 \\
\hline 7482.12 & 29.62 & 17.73 & 5.10 & 8.49 & 3.40 & 29.93 & 3.78 & 1.94 \\
\hline 7484.11 & 46.78 & 32.16 & 7.40 & 7.04 & 5.62 & 0.74 & 0.00 & 0.25 \\
\hline 7485.03 & 46.83 & 32.26 & 6.76 & 6.88 & 5.76 & 0.48 & 0.78 & 0.25 \\
\hline 7485.60 & 46.39 & 31.61 & 7.36 & 8.11 & 5.50 & 0.78 & 0.00 & 0.26 \\
\hline 7488.15 & 47.15 & 31.63 & 4.51 & 7.57 & 5.37 & 0.41 & 3.10 & 0.26 \\
\hline 7489.06 & 45.55 & 31.59 & 6.52 & 8.39 & 5.46 & 0.85 & 1.40 & 0.24 \\
\hline 7491.22 & 44.78 & 32.07 & 6.96 & 8.26 & 5.74 & 1.21 & 0.70 & 0.28 \\
\hline 7492.06 & 41.49 & 29.58 & 6.18 & 8.62 & 5.36 & 1.11 & 1.34 & 6.32 \\
\hline 7494.20 & 45.93 & 31.68 & 6.18 & 7.38 & 5.56 & 1.49 & 1.56 & 0.23 \\
\hline 7497.39 & 39.31 & 26.54 & 5.32 & 13.64 & 4.90 & 7.73 & 0.97 & 1.59 \\
\hline 7500.60 & 46.03 & 23.53 & 3.76 & 8.67 & 5.26 & 6.55 & 2.04 & 4.16 \\
\hline 7503.04 & 56.90 & 22.64 & 0.00 & 7.91 & 4.63 & 2.85 & 4.89 & 0.18 \\
\hline 7503.98 & 57.42 & 22.05 & 0.00 & 7.56 & 4.83 & 2.44 & 5.50 & 0.21 \\
\hline 7505.93 & 53.58 & 25.17 & 0.00 & 11.95 & 5.25 & 0.79 & 4.63 & 0.20 \\
\hline 7506.99 & 56.22 & 25.60 & 0.00 & 7.93 & 5.15 & 0.06 & 4.85 & 0.19 \\
\hline 7509.01 & 45.74 & 18.60 & 0.00 & 10.88 & 3.97 & 15.83 & 4.79 & 0.19 \\
\hline
\end{tabular}




\begin{tabular}{lcccccccc}
$\mathbf{7 5 1 2 . 0 1}$ & 56.44 & 23.31 & 0.00 & 9.61 & 5.33 & 0.28 & 4.80 & 0.23 \\
$\mathbf{7 5 1 3 . 0 8}$ & 52.28 & 25.12 & 0.00 & 8.51 & 4.92 & 2.28 & 6.67 & 0.21 \\
$\mathbf{7 5 1 4 . 1 0}$ & 54.11 & 25.06 & 0.00 & 8.30 & 4.70 & 2.54 & 5.09 & 0.20 \\
$\mathbf{7 5 1 5 . 8 0}$ & 49.02 & 27.66 & 0.00 & 8.15 & 5.14 & 4.55 & 5.28 & 0.20 \\
$\mathbf{7 5 1 7 . 2 3}$ & 47.33 & 26.24 & 0.00 & 6.42 & 5.63 & 9.59 & 4.57 & 0.22 \\
$\mathbf{7 5 1 9 . 0 5}$ & 38.94 & 22.55 & 0.00 & 11.27 & 4.79 & 6.48 & 6.70 & 9.27 \\
$\mathbf{7 5 2 0 . 1 3}$ & 45.69 & 28.06 & 0.00 & 6.95 & 5.81 & 3.09 & 10.17 & 0.23 \\
$\mathbf{7 5 2 2 . 0 5}$ & 47.38 & 30.56 & 0.00 & 7.23 & 6.74 & 2.45 & 5.35 & 0.29 \\
$\mathbf{7 5 2 3 . 0 3}$ & 45.30 & 31.71 & 0.00 & 4.41 & 5.74 & 7.62 & 4.92 & 0.31 \\
$\mathbf{7 5 2 3 . 8 9}$ & 5.98 & 1.62 & 0.00 & 3.76 & 0.88 & 75.88 & 0.00 & 11.87 \\
$\mathbf{7 5 2 4 . 9 0}$ & 42.74 & 27.37 & 0.00 & 3.84 & 5.59 & 13.76 & 6.41 & 0.29 \\
$\mathbf{7 5 2 8 . 0 1}$ & 49.02 & 27.31 & 0.00 & 7.11 & 5.30 & 6.04 & 5.01 & 0.21 \\
$\mathbf{7 5 3 0 . 1 5}$ & 49.27 & 26.55 & 0.00 & 10.28 & 5.58 & 3.87 & 0.00 & 4.45 \\
$\mathbf{7 5 3 3 . 0 2}$ & 47.09 & 26.79 & 0.00 & 7.19 & 5.26 & 9.05 & 4.40 & 0.21 \\
$\mathbf{7 5 3 4 . 0 4}$ & 48.47 & 27.38 & 0.00 & 7.08 & 5.71 & 6.41 & 4.68 & 0.28 \\
$\mathbf{7 5 3 4 . 8 9}$ & 55.25 & 28.37 & 0.00 & 7.03 & 5.83 & 3.32 & 0.00 & 0.19 \\
$\mathbf{7 5 3 8 . 1 5}$ & 48.64 & 29.58 & 0.00 & 9.91 & 6.09 & 0.19 & 5.74 & 0.23 \\
$\mathbf{7 5 4 2 . 9 3}$ & 39.91 & 14.88 & 0.00 & 8.96 & 4.44 & 28.24 & 3.38 & 0.20 \\
$\mathbf{7 5 4 4 . 3 7}$ & 30.41 & 13.76 & 0.00 & 9.81 & 5.36 & 5.14 & 3.98 & 31.54 \\
$\mathbf{7 5 4 4 . 8 5}$ & 34.31 & 15.12 & 0.00 & 14.59 & 5.44 & 4.17 & 3.48 & 22.90 \\
$\mathbf{7 5 4 5 . 7 7}$ & 49.77 & 21.86 & 0.00 & 13.20 & 4.52 & 3.55 & 6.86 & 0.25 \\
$\mathbf{7 5 5 4 . 3 3}$ & 23.29 & 0.58 & 0.00 & 0.60 & 0.00 & 75.46 & 0.00 & 0.07 \\
$\mathbf{7 5 5 6 . 1 5}$ & 46.99 & 23.26 & 0.00 & 6.58 & 4.96 & 10.67 & 7.34 & 0.19 \\
\hline $\mathbf{7}$ & & & & & & & &
\end{tabular}


APPENDIX IV. RIR interpretation of bulk mineralogy for samples collected from the WV-6 well. Samples collected from the Mahantango Formation are colored in brown, with the sample from the Marcellus Shale colored in blue.

\begin{tabular}{|c|c|c|c|c|c|c|c|c|}
\hline Depth (ft) & Quartz & Ill. + Musc. & Chlor. & Pyrite & Albite & Calcite & Dol. & Gyp. \\
\hline 7222.3 & 12 & 44 & 23 & 0 & 5 & 6 & 2 & 8 \\
\hline 7225.3 & 15 & 54 & 21 & 1 & 4 & 1 & 0 & 3 \\
\hline 7228.1 & 19 & 56 & 18 & 2 & 5 & 0 & 0 & 0 \\
\hline 7229.9 & 17 & 59 & 16 & 2 & 6 & 0 & 0 & 0 \\
\hline 7233.3 & 15 & 54 & 25 & 1 & 6 & 0 & 0 & 0 \\
\hline 7237.3 & 13 & 52 & 26 & 2 & 6 & 0 & 1 & 0 \\
\hline 7240.2 & 17 & 56 & 16 & 5 & 5 & 0 & 0 & 3 \\
\hline 7244.4 & 15 & 57 & 18 & 1 & 5 & 1 & 0 & 3 \\
\hline 7245.8 & 15 & 61 & 18 & 1 & 4 & 0 & 0 & 0 \\
\hline 7247.6 & 15 & 54 & 20 & 1 & 5 & 0 & 2 & 4 \\
\hline 7249.9 & 13 & 50 & 24 & 2 & 5 & 0 & 0 & 7 \\
\hline 7252.2 & 12 & 49 & 22 & 2 & 6 & 3 & 1 & 6 \\
\hline 7255.8 & 14 & 60 & 18 & 3 & 5 & 0 & 0 & 0 \\
\hline 7258.3 & 19 & 56 & 16 & 3 & 4 & 0 & 0 & 2 \\
\hline 7261.9 & 20 & 57 & 14 & 2 & 4 & 0 & 0 & 4 \\
\hline 7264.6 & 13 & 53 & 21 & 1 & 5 & 0 & 0 & 7 \\
\hline 7267.8 & 19 & 58 & 12 & 3 & 4 & 0 & 0 & 3 \\
\hline 7270.3 & 25 & 54 & 11 & 5 & 3 & 0 & 0 & 2 \\
\hline 7272.7 & 16 & 58 & 14 & 4 & 5 & 0 & 0 & 4 \\
\hline 7275.9 & 14 & 58 & 16 & 2 & 5 & 0 & 0 & 4 \\
\hline 7278.6 & 12 & 44 & 21 & 3 & 6 & 0 & 0 & 14 \\
\hline 7281.7 & 18 & 57 & 14 & 3 & 4 & 1 & 0 & 3 \\
\hline 7284.7 & 15 & 60 & 15 & 3 & 4 & 0 & 0 & 3 \\
\hline 7287.8 & 15 & 59 & 16 & 2 & 5 & 0 & 0 & 3 \\
\hline 7290.5 & 14 & 59 & 17 & 2 & 4 & 0 & 0 & 5 \\
\hline 7296.9 & 18 & 57 & 15 & 3 & 4 & 0 & 0 & 3 \\
\hline 7299.9 & 17 & 60 & 13 & 3 & 4 & 0 & 0 & 3 \\
\hline 7303 & 19 & 58 & 14 & 2 & 4 & 0 & 0 & 3 \\
\hline 7305.8 & 19 & 55 & 13 & 3 & 3 & 1 & 2 & 3 \\
\hline 7309.2 & 15 & 59 & 16 & 2 & 4 & 0 & 0 & 4 \\
\hline 7311.9 & 13 & 51 & 22 & 2 & 5 & 0 & 2 & 5 \\
\hline 7314.7 & 31 & 50 & 10 & 3 & 3 & 0 & 0 & 2 \\
\hline 7317.8 & 35 & 47 & 10 & 3 & 3 & 0 & 0 & 2 \\
\hline 7320.7 & 21 & 57 & 12 & 3 & 4 & 0 & 0 & 3 \\
\hline 7323.5 & 13 & 57 & 18 & 2 & 5 & 0 & 0 & 5 \\
\hline 7326.7 & 12 & 50 & 21 & 1 & 5 & 1 & 2 & 7 \\
\hline 7330.3 & 24 & 51 & 13 & 4 & 3 & 1 & 1 & 2 \\
\hline 7333.1 & 25 & 52 & 13 & 1 & 3 & 1 & 2 & 3 \\
\hline
\end{tabular}




\begin{tabular}{ccccccccc}
$\mathbf{7 3 3 6 . 5}$ & 26 & 46 & 12 & 3 & 2 & 5 & 4 & 2 \\
$\mathbf{7 3 3 8 . 9}$ & 22 & 54 & 12 & 4 & 3 & 1 & 1 & 3 \\
$\mathbf{7 3 4 2 . 3}$ & 35 & 49 & 7 & 3 & 3 & 0 & 0 & 3 \\
$\mathbf{7 3 4 4 . 9}$ & 27 & 52 & 10 & 5 & 3 & 0 & 0 & 4 \\
$\mathbf{7 3 4 7 . 8}$ & 34 & 50 & 7 & 4 & 3 & 0 & 0 & 2 \\
$\mathbf{7 3 5 1}$ & 35 & 44 & 9 & 8 & 3 & 0 & 0 & 2 \\
$\mathbf{7 3 5 4 . 4}$ & 11 & 24 & 9 & 13 & 0 & 37 & 6 & 0 \\
$\mathbf{7 3 5 7 . 3}$ & 29 & 50 & 9 & 6 & 3 & 0 & 0 & 3 \\
$\mathbf{7 3 6 0 . 5}$ & 17 & 54 & 12 & 3 & 3 & 3 & 4 & 4 \\
$\mathbf{7 3 6 3 . 4}$ & 17 & 56 & 12 & 3 & 3 & 3 & 1 & 4 \\
$\mathbf{7 3 6 6 . 9}$ & 19 & 57 & 11 & 3 & 4 & 2 & 0 & 3 \\
$\mathbf{7 3 6 9 . 9}$ & 17 & 54 & 13 & 2 & 4 & 3 & 2 & 5 \\
$\mathbf{7 3 7 3 . 1}$ & 13 & 51 & 18 & 2 & 5 & 0 & 0 & 11 \\
$\mathbf{7 3 7 7 . 2}$ & 17 & 57 & 12 & 4 & 5 & 0 & 0 & 5 \\
$\mathbf{7 3 8 1 . 1}$ & 18 & 52 & 12 & 6 & 3 & 3 & 2 & 4 \\
$\mathbf{7 3 8 3 . 2}$ & 21 & 58 & 8 & 7 & 4 & 0 & 0 & 3 \\
$\mathbf{7 3 8 5 . 7}$ & 21 & 57 & 8 & 7 & 4 & 0 & 0 & 3 \\
$\mathbf{7 3 8 8 . 1}$ & 20 & 41 & 11 & 12 & 2 & 9 & 1 & 4 \\
$\mathbf{7 3 9 1 . 2}$ & 34 & 46 & 6 & 9 & 3 & 0 & 0 & 2 \\
$\mathbf{7 3 9 4 . 2}$ & 29 & 52 & 6 & 8 & 3 & 0 & 0 & 2 \\
$\mathbf{7 3 9 7 . 8}$ & 14 & 53 & 14 & 8 & 4 & 3 & 0 & 6 \\
\hline
\end{tabular}


APPENDIX V. XRF-quantified interpretation of bulk mineralogy for samples collected from the WV-6 well. Samples collected from the Mahantango Formation are colored in brown, with the sample from the Marcellus Shale colored in blue.

\begin{tabular}{|c|c|c|c|c|c|c|c|c|c|}
\hline Depth (ft) & Qtz & $\begin{array}{c}\text { Ill.+ } \\
\text { Musc. }\end{array}$ & Chlor. & Pyrt. & Alb. & Calc. & Dol. & Bar. & Gyp. \\
\hline 7222.3 & 43.37 & 27.46 & 7.50 & 5.72 & 4.41 & 7.35 & 2.06 & 0.15 & 1.97 \\
\hline 7225.3 & 44.19 & 30.67 & 9.69 & 7.10 & 5.04 & 1.33 & 0.00 & 0.15 & 1.84 \\
\hline 7228.1 & 44.02 & 32.97 & 10.29 & 6.28 & 6.27 & 0.00 & 0.00 & 0.18 & 0.00 \\
\hline 7229.9 & 51.17 & 27.52 & 8.40 & 7.00 & 5.77 & 0.00 & 0.00 & 0.14 & 0.00 \\
\hline 7233.3 & 47.15 & 30.76 & 10.20 & 6.64 & 5.09 & 0.00 & 0.00 & 0.15 & 0.00 \\
\hline 7237.3 & 48.13 & 29.40 & 9.03 & 7.49 & 5.09 & 0.00 & 0.73 & 0.14 & 0.00 \\
\hline 7240.2 & 44.42 & 30.01 & 8.61 & 10.03 & 5.84 & 0.00 & 0.00 & 0.15 & 0.95 \\
\hline 7244.4 & 46.54 & 30.64 & 9.29 & 6.38 & 5.23 & 0.98 & 0.00 & 0.15 & 0.78 \\
\hline 7245.8 & 46.49 & 32.16 & 9.52 & 6.51 & 5.16 & 0.00 & 0.00 & 0.16 & 0.00 \\
\hline 7247.6 & 46.22 & 28.04 & 9.64 & 6.63 & 4.94 & 0.00 & 1.04 & 0.15 & 3.34 \\
\hline 7249.9 & 45.05 & 31.47 & 9.56 & 6.98 & 5.67 & 0.00 & 0.00 & 0.15 & 1.12 \\
\hline 7252.2 & 43.50 & 29.77 & 9.17 & 7.21 & 5.12 & 2.93 & 0.49 & 0.15 & 1.65 \\
\hline 7255.8 & 44.29 & 34.27 & 8.79 & 7.12 & 5.34 & 0.00 & 0.00 & 0.18 & 0.00 \\
\hline 7258.3 & 40.63 & 27.36 & 10.10 & 13.84 & 4.55 & 0.00 & 0.00 & 0.22 & 3.30 \\
\hline 7261.9 & 43.99 & 30.27 & 9.31 & 7.46 & 5.12 & 0.00 & 0.00 & 0.17 & 3.68 \\
\hline 7264.6 & 43.67 & 30.69 & 9.11 & 8.12 & 4.91 & 0.00 & 0.00 & 0.17 & 3.33 \\
\hline 7267.8 & 44.62 & 32.15 & 8.93 & 8.01 & 5.20 & 0.00 & 0.00 & 0.18 & 0.92 \\
\hline 7270.3 & 45.29 & 32.28 & 8.77 & 7.70 & 5.18 & 0.00 & 0.00 & 0.18 & 0.61 \\
\hline 7272.7 & 43.81 & 31.06 & 8.84 & 9.92 & 5.15 & 0.00 & 0.00 & 0.17 & 1.06 \\
\hline 7275.9 & 45.52 & 31.72 & 9.13 & 7.05 & 5.44 & 0.00 & 0.00 & 0.18 & 0.96 \\
\hline 7278.6 & 45.22 & 31.39 & 9.15 & 7.66 & 5.07 & 0.00 & 0.00 & 0.17 & 1.33 \\
\hline 7281.7 & 40.69 & 27.90 & 10.07 & 7.79 & 4.02 & 2.74 & 0.00 & 0.16 & 6.62 \\
\hline 7284.7 & 45.43 & 31.71 & 9.20 & 7.50 & 5.10 & 0.00 & 0.00 & 0.18 & 0.89 \\
\hline 7287.8 & 45.53 & 31.33 & 9.51 & 7.09 & 5.39 & 0.00 & 0.00 & 0.18 & 0.98 \\
\hline 7290.5 & 44.69 & 30.62 & 9.67 & 7.91 & 5.26 & 0.00 & 0.00 & 0.17 & 1.67 \\
\hline 7296.9 & 44.93 & 30.62 & 9.80 & 7.89 & 4.93 & 0.00 & 0.00 & 0.17 & 1.67 \\
\hline 7299.9 & 46.16 & 31.14 & 9.13 & 7.41 & 4.94 & 0.00 & 0.00 & 0.17 & 1.05 \\
\hline 7303 & 45.82 & 30.64 & 9.50 & 7.30 & 4.77 & 0.00 & 0.00 & 0.17 & 1.80 \\
\hline 7305.8 & 44.04 & 29.72 & 8.30 & 8.35 & 4.64 & 0.92 & 1.36 & 0.18 & 2.50 \\
\hline 7309.2 & 44.81 & 30.79 & 9.72 & 7.88 & 5.03 & 0.00 & 0.00 & 0.17 & 1.59 \\
\hline 7311.9 & 44.60 & 29.74 & 9.65 & 8.14 & 4.60 & 0.00 & 1.04 & 0.16 & 2.06 \\
\hline 7314.7 & 46.05 & 31.05 & 9.05 & 7.31 & 4.98 & 0.00 & 0.00 & 0.18 & 1.37 \\
\hline 7317.8 & 45.83 & 30.88 & 9.08 & 7.26 & 4.90 & 0.00 & 0.00 & 0.18 & 1.88 \\
\hline 7320.7 & 45.38 & 31.32 & 9.32 & 7.31 & 4.73 & 0.00 & 0.00 & 0.18 & 1.76 \\
\hline 7323.5 & 45.46 & 31.58 & 9.06 & 7.43 & 5.00 & 0.00 & 0.00 & 0.18 & 1.29 \\
\hline 7326.7 & 45.04 & 30.98 & 8.80 & 7.03 & 4.56 & 0.48 & 1.09 & 0.18 & 1.84 \\
\hline 7330.3 & 44.94 & 31.85 & 8.42 & 6.96 & 4.95 & 0.99 & 0.55 & 0.18 & 1.16 \\
\hline
\end{tabular}




\begin{tabular}{cccccccccc}
$\mathbf{7 3 3 3 . 1}$ & 43.28 & 32.12 & 8.88 & 6.58 & 4.56 & 0.86 & 0.95 & 0.18 & 2.58 \\
$\mathbf{7 3 3 6 . 5}$ & 40.64 & 26.27 & 8.82 & 7.89 & 3.64 & 7.58 & 1.98 & 0.19 & 2.99 \\
$\mathbf{7 3 3 8 . 9}$ & 45.92 & 31.16 & 8.07 & 7.24 & 4.96 & 0.35 & 0.43 & 0.17 & 1.70 \\
$\mathbf{7 3 4 2 . 3}$ & 47.91 & 29.55 & 8.19 & 7.10 & 4.89 & 0.00 & 0.00 & 0.18 & 2.19 \\
$\mathbf{7 3 4 4 . 9}$ & 48.61 & 29.33 & 8.17 & 6.45 & 4.92 & 0.00 & 0.00 & 0.17 & 2.35 \\
$\mathbf{7 3 4 7 . 8}$ & 48.89 & 30.53 & 8.00 & 6.35 & 4.98 & 0.00 & 0.00 & 0.19 & 1.07 \\
$\mathbf{7 3 5 1}$ & 47.82 & 30.13 & 8.15 & 7.03 & 4.56 & 0.00 & 0.00 & 0.20 & 2.11 \\
$\mathbf{7 3 5 4 . 4}$ & 10.69 & 3.88 & 3.32 & 9.12 & 0.52 & 66.43 & 5.54 & 0.50 & 0.00 \\
$\mathbf{7 3 5 7 . 3}$ & 48.18 & 29.51 & 7.98 & 7.49 & 4.49 & 0.00 & 0.00 & 0.20 & 2.15 \\
$\mathbf{7 3 6 0 . 5}$ & 50.25 & 26.56 & 5.00 & 7.02 & 4.42 & 2.17 & 2.43 & 0.16 & 1.99 \\
$\mathbf{7 3 6 3 . 4}$ & 49.17 & 27.78 & 7.12 & 6.62 & 4.49 & 1.97 & 0.83 & 0.17 & 1.85 \\
$\mathbf{7 3 6 6 . 9}$ & 50.26 & 28.48 & 7.79 & 6.21 & 4.53 & 1.24 & 0.00 & 0.18 & 1.31 \\
$\mathbf{7 3 6 9 . 9}$ & 50.26 & 28.45 & 6.34 & 6.79 & 4.79 & 0.96 & 1.18 & 0.17 & 1.06 \\
$\mathbf{7 3 7 3 . 1}$ & 49.03 & 30.11 & 7.67 & 7.13 & 4.69 & 0.00 & 0.00 & 0.18 & 1.20 \\
$\mathbf{7 3 7 7 . 2}$ & 50.14 & 27.62 & 7.43 & 8.62 & 4.63 & 0.00 & 0.00 & 0.17 & 1.39 \\
$\mathbf{7 3 8 1 . 1}$ & 44.47 & 28.36 & 7.27 & 8.71 & 4.23 & 1.98 & 1.86 & 0.17 & 2.95 \\
$\mathbf{7 3 8 3 . 2}$ & 49.12 & 29.39 & 7.43 & 8.29 & 4.92 & 0.00 & 0.00 & 0.18 & 0.67 \\
$\mathbf{7 3 8 5 . 7}$ & 48.15 & 30.11 & 7.59 & 8.42 & 4.94 & 0.00 & 0.00 & 0.19 & 0.59 \\
$\mathbf{7 3 8 8 . 1}$ & 34.70 & 26.17 & 6.96 & 13.39 & 3.40 & 9.79 & 0.75 & 0.17 & 4.66 \\
$\mathbf{7 3 9 1 . 2}$ & 46.76 & 30.37 & 7.75 & 9.36 & 4.76 & 0.00 & 0.00 & 0.19 & 0.82 \\
$\mathbf{7 3 9 4 . 2}$ & 44.32 & 33.81 & 8.14 & 8.31 & 4.37 & 0.00 & 0.00 & 0.21 & 0.84 \\
$\mathbf{7 3 9 7 . 8}$ & 41.56 & 30.31 & 7.82 & 11.66 & 4.14 & 1.03 & 0.00 & 0.19 & 3.30 \\
\hline $\mathbf{7 3 9 5}$
\end{tabular}


APPENDIX VI. Image of prepared samples for XRF analysis.

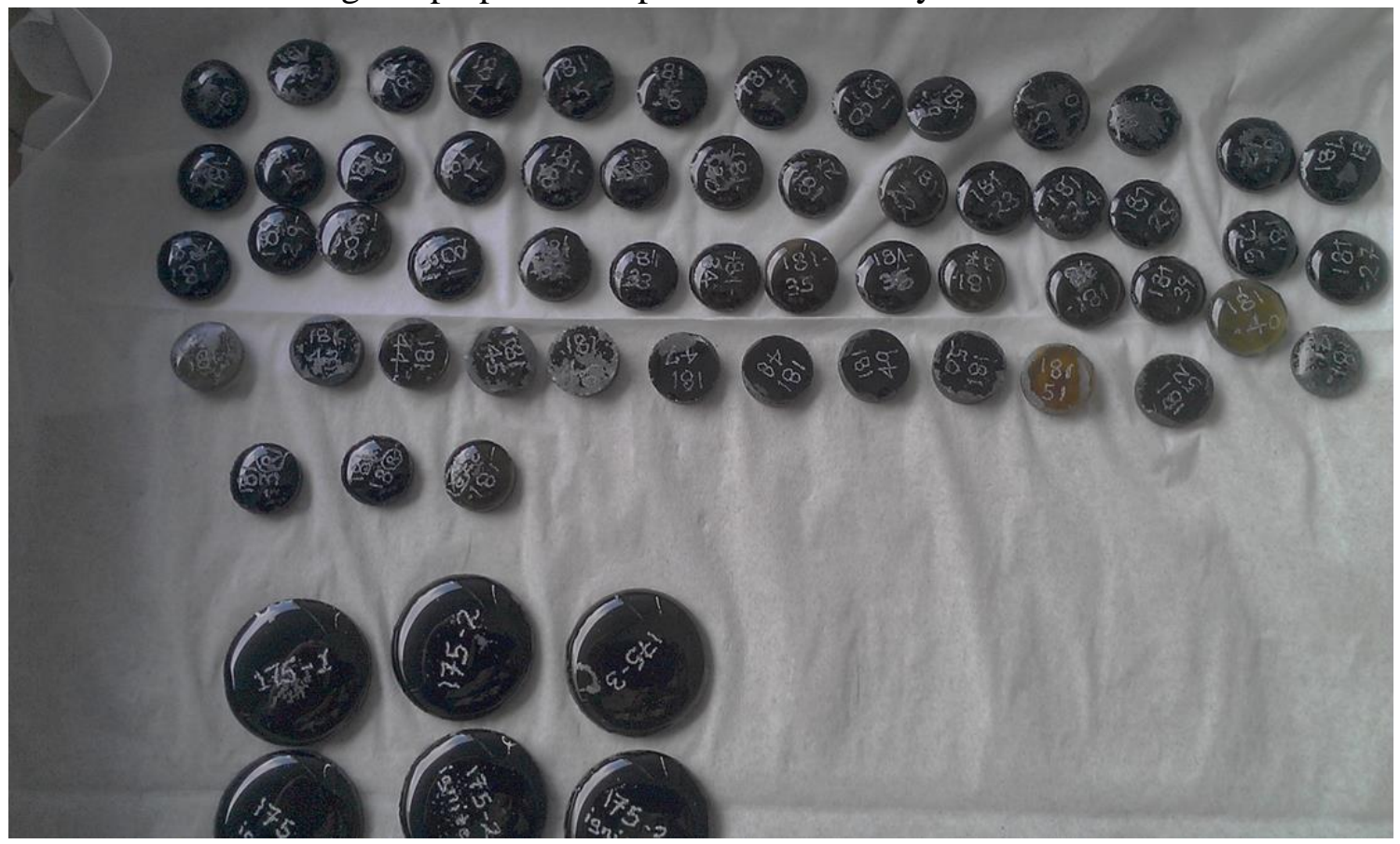


APPENDIX VII. Petrographic analysis estimates of classification scheme end members and rock identification assigned to each sample. Samples from the Mahantango Formation are scripted in brown, with Marcellus Shale samples indicated by blue script.

\begin{tabular}{|c|c|c|c|c|c|c|c|c|}
\hline \multirow[b]{2}{*}{$\begin{array}{c}\text { Depth } \\
\text { (ft) }\end{array}$} & \multirow[b]{2}{*}{ Well } & \multicolumn{3}{|c|}{ Milliken (2014) } & \multicolumn{3}{|c|}{ Picard (1971) } & \multirow[b]{2}{*}{ Name } \\
\hline & & $\begin{array}{l}\text { Terr./ } \\
\text { Volc. }\end{array}$ & $\begin{array}{c}\text { Cal } \\
\text { c. } \\
\text { all. }\end{array}$ & $\begin{array}{l}\text { Bio- } \\
\text { sil. all. }\end{array}$ & Clay & Sand & Silt & \\
\hline 7221 & WV6 & & & & 74 & 1 & 25 & Silty claystone \\
\hline 7237 & WV6 & & & & 85 & & 15 & Claystone \\
\hline 7251 & WV6 & & & & 98 & & 2 & Claystone \\
\hline 7268 & WV6 & & & & 94 & 1 & 5 & Claystone \\
\hline 7284 & WV6 & & & & 85 & & 15 & Claystone \\
\hline 7299 & WV6 & & & & 75 & & 25 & Silty claystone \\
\hline 7314 & WV6 & & & & 80 & & 20 & Claystone \\
\hline 7330 & WV6 & 97 & & 3 & & & & Tarl \\
\hline 7347 & WV6 & 90 & & 10 & & & & Bio-siliceous tarl \\
\hline 7363 & WV6 & & & & 90 & & 10 & Claystone \\
\hline 7381 & WV6 & & & & 90 & & 10 & Claystone \\
\hline 7448 & $\mathrm{M} 3 \mathrm{H}$ & & & & 90 & & 10 & Claystone \\
\hline 7451 & M3H & 90 & & 10 & & & & Bio-siliceous tarl \\
\hline 7457 & M3H & & & & 95 & & 5 & Claystone \\
\hline 7460 & M3H & & & & 99 & & 1 & Claystone \\
\hline 7464 & $\mathrm{M} 3 \mathrm{H}$ & 90 & & 10 & & & & Bio-siliceous tarl \\
\hline 7467 & M3H & 92 & 8 & & & & & Tarl \\
\hline 7472 & $\mathrm{M} 3 \mathrm{H}$ & & & & 75 & & 25 & Silty Claystone \\
\hline 7475 & M3H & 80 & & 20 & & & & Bio-siliceous tarl \\
\hline 7505 & M3H & & & & 90 & & 10 & Claystone \\
\hline 7514 & M3H & & & & 98 & & 2 & Claystone \\
\hline 7515 & M3H & 70 & & 30 & & & & Argillaceous sarl \\
\hline 7522 & $\mathrm{M} 3 \mathrm{H}$ & 73 & 7 & 20 & & & & Argillaceous sarl \\
\hline 7528 & M3H & & & & 65 & & 35 & Silty claystone \\
\hline 7530 & $\mathrm{M} 3 \mathrm{H}$ & & & & 60 & & 40 & Silty claystone \\
\hline 7533 & M3H & & & & 80 & & 20 & Claystone \\
\hline 7534 & $\mathrm{M} 3 \mathrm{H}$ & 75 & & 25 & & & & Argillaceous sarl \\
\hline 7542 & $\mathrm{M} 3 \mathrm{H}$ & 70 & 10 & 20 & & & & Bio-siliceous tarl \\
\hline 7544 & $\mathrm{M} 3 \mathrm{H}$ & 60 & & 40 & & & & Argillaceous sarl \\
\hline 7554 & M3H & 30 & 70 & & & & & Carl \\
\hline 7556 & $\mathrm{M} 3 \mathrm{H}$ & 60 & 10 & 30 & & & & Argillaceous sarl \\
\hline
\end{tabular}


APPENDIX VIII. Major element concentrations (weight percent) of the samples collected from the MIP-3H well. Samples collected from the Marcellus Shale (MS) are colored in blue, with samples from the Mahantango Formation (MF) are colored in brown. $\mathrm{FeO}^{*}$ indicates the total iron expressed as $\mathrm{FeO}$.

\begin{tabular}{|c|c|c|c|c|c|c|c|c|c|c|c|}
\hline Depth (ft) & $\mathrm{SiO}_{2}$ & $\mathrm{TiO}_{2}$ & $\mathrm{Al}_{2} \mathrm{O}_{3}$ & $\mathrm{FeO}^{*}$ & MnO & $\mathrm{MgO}$ & $\mathrm{CaO}$ & $\mathrm{Na}_{2} \mathrm{O}$ & $\mathrm{K}_{2} \mathrm{O}$ & $\mathbf{P}_{2} \mathrm{O}_{5}$ & LOI \\
\hline 7447.20 & 58.54 & 0.691 & 16.52 & 5.86 & 0.022 & 1.40 & 0.86 & 0.67 & 3.97 & 0.079 & 9.20 \\
\hline 7448.35 & 57.98 & 0.718 & 17.18 & 5.71 & 0.019 & 1.38 & 0.42 & 0.63 & 4.13 & 0.066 & 9.60 \\
\hline 7449.25 & 57.34 & 0.737 & 17.50 & 6.66 & 0.019 & 1.41 & 0.36 & 0.71 & 4.20 & 0.062 & 9.49 \\
\hline 7450.20 & 59.40 & 0.708 & 16.73 & 5.84 & 0.020 & 1.34 & 0.43 & 0.70 & 4.02 & 0.070 & 8.90 \\
\hline 7452.22 & 60.10 & 0.674 & 15.72 & 6.03 & 0.019 & 1.28 & 0.30 & 0.69 & 3.78 & 0.067 & 8.58 \\
\hline 7455.00 & 40.83 & 0.545 & 12.41 & 6.82 & 0.073 & 2.23 & 16.68 & 0.35 & 2.43 & 0.062 & 13.52 \\
\hline 7456.16 & 53.01 & 0.734 & 18.86 & 6.03 & 0.017 & 1.40 & 0.49 & 0.72 & 4.54 & 0.074 & 11.90 \\
\hline 7457.15 & 55.14 & 0.697 & 17.03 & 6.18 & 0.018 & 1.37 & 0.55 & 0.70 & 4.12 & 0.074 & 10.49 \\
\hline 7457.37 & 59.77 & 0.648 & 15.68 & 6.89 & 0.022 & 1.36 & 0.98 & 0.68 & 3.84 & 0.092 & 9.24 \\
\hline 7459.13 & 53.09 & 0.708 & 18.71 & 7.05 & 0.017 & 1.49 & 0.52 & 0.69 & 4.44 & 0.073 & 11.67 \\
\hline 7460.20 & 53.53 & 0.708 & 19.12 & 5.97 & 0.017 & 1.52 & 0.33 & 0.68 & 4.56 & 0.077 & 12.11 \\
\hline 7463.10 & 55.76 & 0.761 & 19.12 & 5.33 & 0.018 & 1.47 & 0.43 & 0.72 & 4.60 & 0.085 & 9.81 \\
\hline 7464.05 & 53.12 & 0.700 & 18.50 & 5.52 & 0.019 & 1.45 & 1.49 & 0.68 & 4.49 & 0.073 & 10.94 \\
\hline 7465.30 & 53.21 & 0.673 & 17.88 & 6.81 & 0.017 & 1.40 & 0.65 & 0.73 & 4.31 & 0.067 & 12.14 \\
\hline 7467.30 & 39.31 & 0.490 & 13.40 & 5.75 & 0.064 & 1.48 & 16.98 & 0.47 & 3.16 & 0.068 & 15.88 \\
\hline 7470.05 & 54.87 & 0.683 & 18.99 & 5.46 & 0.017 & 1.40 & 0.48 & 0.72 & 4.57 & 0.067 & 11.37 \\
\hline 7471.13 & 51.90 & 0.633 & 17.11 & 5.73 & 0.019 & 1.36 & 1.97 & 0.66 & 4.22 & 0.066 & 12.08 \\
\hline 7472.09 & 51.59 & 0.678 & 18.17 & 5.62 & 0.016 & 1.38 & 0.42 & 0.69 & 4.47 & 0.075 & 12.89 \\
\hline 7475.12 & 49.81 & 0.670 & 17.74 & 5.99 & 0.018 & 1.34 & 1.33 & 0.68 & 4.32 & 0.298 & 12.93 \\
\hline 7476.15 & 50.75 & 0.666 & 18.13 & 6.25 & 0.021 & 1.36 & 2.64 & 0.67 & 4.48 & 0.060 & 11.64 \\
\hline 7477.07 & 50.69 & 0.699 & 17.78 & 7.90 & 0.018 & 1.33 & 2.21 & 0.63 & 4.36 & 0.068 & 11.78 \\
\hline 7479.05 & 53.43 & 0.704 & 18.07 & 5.15 & 0.019 & 1.26 & 0.73 & 0.71 & 4.38 & 0.057 & 10.75 \\
\hline 7480.05 & 56.48 & 0.778 & 18.40 & 4.95 & 0.019 & 1.30 & 0.62 & 0.74 & 4.47 & 0.062 & 9.53 \\
\hline 7482.12 & 35.33 & 0.398 & 9.95 & 5.44 & 0.056 & 1.80 & 19.15 & 0.43 & 2.34 & 0.069 & 17.29 \\
\hline 7484.11 & 57.21 & 0.715 & 17.63 & 4.62 & 0.017 & 1.36 & 0.45 & 0.73 & 4.36 & 0.059 & 10.76 \\
\hline 7485.03 & 56.92 & 0.716 & 17.56 & 4.49 & 0.018 & 1.42 & 0.55 & 0.74 & 4.35 & 0.067 & 10.35 \\
\hline 7485.60 & 57.79 & 0.724 & 17.63 & 5.43 & 0.018 & 1.38 & 0.49 & 0.73 & 4.37 & 0.059 & 9.79 \\
\hline 7488.15 & 57.15 & 0.739 & 17.16 & 5.01 & 0.022 & 1.58 & 1.30 & 0.70 & 4.32 & 0.055 & 9.85 \\
\hline 7489.06 & 56.22 & 0.736 & 17.52 & 5.57 & 0.021 & 1.55 & 1.00 & 0.71 & 4.33 & 0.054 & 9.77 \\
\hline 7491.22 & 55.26 & 0.757 & 17.67 & 5.45 & 0.019 & 1.45 & 0.98 & 0.75 & 4.37 & 0.059 & 10.81 \\
\hline 7492.06 & 52.84 & 0.663 & 17.08 & 5.87 & 0.021 & 1.51 & 1.17 & 0.72 & 4.16 & 0.062 & 11.75 \\
\hline 7494.20 & 55.85 & 0.696 & 17.20 & 4.83 & 0.019 & 1.51 & 1.43 & 0.72 & 4.29 & 0.059 & 11.32 \\
\hline 7497.39 & 48.22 & 0.594 & 14.31 & 9.00 & 0.026 & 1.22 & 5.09 & 0.64 & 3.62 & 0.082 & 11.54 \\
\hline 7500.60 & 53.90 & 0.517 & 12.07 & 5.55 & 0.026 & 1.15 & 4.59 & 0.66 & 3.11 & 0.063 & 12.30 \\
\hline 7503.04 & 60.00 & 0.470 & 10.90 & 4.74 & 0.017 & 1.07 & 3.08 & 0.55 & 2.80 & 0.075 & 13.37 \\
\hline 7503.98 & 60.20 & 0.468 & 10.79 & 4.49 & 0.018 & 1.19 & 3.01 & 0.57 & 2.71 & 0.085 & 13.75 \\
\hline 7505.93 & 59.08 & 0.575 & 12.59 & 7.41 & 0.014 & 1.05 & 1.00 & 0.64 & 3.22 & 0.074 & 13.20 \\
\hline 7506.99 & 59.95 & 0.545 & 12.32 & 4.77 & 0.014 & 1.06 & 1.51 & 0.61 & 3.18 & 0.077 & 13.58 \\
\hline 7509.01 & 51.75 & 0.412 & 9.30 & 6.97 & 0.025 & 1.12 & 11.04 & 0.50 & 2.46 & 0.181 & 11.23 \\
\hline 7512.01 & 58.44 & 0.484 & 11.27 & 5.60 & 0.013 & 1.02 & 1.57 & 0.61 & 2.81 & 0.107 & 16.73 \\
\hline 7513.08 & 53.85 & 0.522 & 11.53 & 4.94 & 0.015 & 1.41 & 3.20 & 0.56 & 3.01 & 0.088 & 17.50 \\
\hline 7514.10 & 56.98 & 0.545 & 11.84 & 4.95 & 0.014 & 1.11 & 2.96 & 0.55 & 3.08 & 0.097 & 15.32 \\
\hline 7515.80 & 54.51 & 0.643 & 13.59 & 5.07 & 0.018 & 1.20 & 4.32 & 0.63 & 3.55 & 0.111 & 12.25 \\
\hline 7517.23 & 53.86 & 0.603 & 13.02 & 4.05 & 0.017 & 1.05 & 7.12 & 0.70 & 3.42 & 0.084 & 11.87 \\
\hline 7519.05 & 46.23 & 0.568 & 12.01 & 7.40 & 0.020 & 1.61 & 6.21 & 0.62 & 3.06 & 0.078 & 15.16 \\
\hline
\end{tabular}




\begin{tabular}{cccccccccccc}
\hline 7520.13 & 51.52 & 0.688 & 13.66 & 4.32 & 0.023 & 2.31 & 5.01 & 0.71 & 3.60 & 0.100 & 14.91 \\
7522.05 & 53.18 & 0.761 & 14.88 & 4.43 & 0.018 & 1.20 & 3.07 & 0.81 & 3.87 & 0.100 & 14.41 \\
7523.03 & 53.02 & 0.774 & 15.93 & 2.85 & 0.024 & 1.16 & 6.22 & 0.73 & 4.23 & 0.087 & 11.59 \\
7523.89 & 6.72 & 0.058 & 1.13 & 2.30 & 0.027 & 0.60 & 43.41 & 0.11 & 0.20 & 0.092 & 33.37 \\
7524.90 & 49.83 & 0.728 & 13.75 & 2.46 & 0.026 & 1.50 & 10.34 & 0.71 & 3.63 & 0.131 & 12.97 \\
7528.01 & 54.91 & 0.629 & 13.32 & 4.45 & 0.018 & 1.14 & 5.12 & 0.65 & 3.53 & 0.077 & 13.41 \\
7530.15 & 55.29 & 0.576 & 12.58 & 6.42 & 0.013 & 0.95 & 2.26 & 0.69 & 3.42 & 0.069 & 13.24 \\
7533.02 & 54.36 & 0.580 & 13.00 & 4.62 & 0.018 & 1.03 & 6.88 & 0.67 & 3.56 & 0.065 & 13.25 \\
7534.04 & 54.88 & 0.597 & 13.12 & 4.45 & 0.018 & 1.07 & 5.26 & 0.71 & 3.55 & 0.066 & 13.34 \\
7534.89 & 59.84 & 0.601 & 13.14 & 4.26 & 0.013 & 1.02 & 1.88 & 0.70 & 3.55 & 0.100 & 12.58 \\
7538.15 & 53.01 & 0.558 & 13.62 & 5.96 & 0.013 & 1.26 & 1.65 & 0.72 & 3.68 & 0.073 & 17.12 \\
7542.93 & 41.87 & 0.293 & 6.65 & 5.24 & 0.016 & 0.72 & 16.44 & 0.51 & 1.80 & 0.078 & 18.58 \\
7544.37 & 32.00 & 0.233 & 6.02 & 5.52 & 0.022 & 0.82 & 3.84 & 0.59 & 1.60 & 0.065 & 14.47 \\
7544.85 & 36.60 & 0.289 & 6.75 & 8.42 & 0.016 & 0.73 & 3.27 & 0.62 & 1.80 & 0.078 & 17.30 \\
7545.77 & 49.49 & 0.375 & 8.96 & 7.41 & 0.011 & 1.41 & 3.82 & 0.50 & 2.53 & 0.076 & 22.42 \\
7554.33 & 19.53 & 0.011 & 0.44 & 0.30 & 0.015 & 0.37 & 35.48 & 0.03 & 0.06 & 0.310 & 33.73 \\
7556.15 & 51.79 & 0.490 & 10.12 & 4.06 & 0.009 & 1.65 & 8.45 & 0.60 & 2.96 & 0.103 & 16.31 \\
\hline \hline MF Average & $\mathbf{5 8 . 6 7}$ & $\mathbf{0 . 7 1}$ & $\mathbf{1 6 . 7 3}$ & $\mathbf{6 . 0 2}$ & $\mathbf{0 . 0 2}$ & $\mathbf{1 . 3 6}$ & $\mathbf{0 . 4 7}$ & $\mathbf{0 . 6 8}$ & $\mathbf{4 . 0 2}$ & $\mathbf{0 . 0 7}$ & $\mathbf{9 . 1 6}$ \\
MS Average & $\mathbf{5 1 . 1 5}$ & $\mathbf{0 . 5 9}$ & $\mathbf{1 3 . 9 8}$ & $\mathbf{5 . 4 1}$ & $\mathbf{0 . 0 2}$ & $\mathbf{1 . 2 9}$ & $\mathbf{5 . 1 4}$ & $\mathbf{0 . 6 3}$ & $\mathbf{3 . 5 1}$ & $\mathbf{0 . 0 9}$ & $\mathbf{1 3 . 7 4}$ \\
\hline
\end{tabular}


APPENDIX IX. Major element concentrations (weight percent) of the samples collected from the WV-6 well. Samples collected from the Mahantango Formation (MF) are colored in brown, with samples from the Marcellus Shale colored in blue. FeO* indicates total iron expressed as $\mathrm{FeO}$.

\begin{tabular}{|c|c|c|c|c|c|c|c|c|c|c|c|}
\hline Depth (ft) & $\mathrm{SiO}_{2}$ & $\mathrm{TiO}_{2}$ & $\mathrm{Al}_{2} \mathrm{O}_{3}$ & $\mathrm{FeO}^{*}$ & MnO & MgO & $\mathrm{CaO}$ & $\mathrm{Na}_{2} \mathrm{O}$ & $\mathrm{K}_{2} \mathrm{O}$ & $\mathbf{P}_{2} \mathrm{O}_{5}$ & LOI \\
\hline 7222.3 & 55.75 & 0.720 & 17.28 & 4.78 & 0.042 & 1.99 & 4.40 & 0.61 & 3.95 & 0.096 & 7.6 \\
\hline 7225.3 & 56.28 & 0.781 & 18.63 & 5.83 & 0.034 & 1.84 & 1.34 & 0.67 & 4.29 & 0.114 & 7.9 \\
\hline 7228.1 & 52.89 & 0.623 & 18.93 & 4.93 & 0.027 & 1.81 & 0.54 & 0.77 & 4.27 & 0.101 & 12.4 \\
\hline 7229.9 & 62.24 & 0.594 & 16.23 & 5.43 & 0.025 & 1.54 & 0.24 & 0.75 & 3.72 & 0.071 & 8.1 \\
\hline 7233.3 & 55.25 & 0.644 & 16.99 & 5.14 & 0.055 & 1.79 & 4.68 & 0.63 & 3.98 & 0.086 & 8.0 \\
\hline 7237.3 & 60.08 & 0.822 & 17.77 & 5.97 & 0.036 & 1.88 & 0.98 & 0.67 & 4.08 & 0.118 & 5.9 \\
\hline 7240.2 & 54.08 & 0.639 & 17.10 & 7.31 & 0.029 & 1.55 & 0.42 & 0.74 & 3.99 & 0.053 & 12.6 \\
\hline 7244.4 & 58.30 & 0.670 & 18.16 & 5.23 & 0.028 & 1.74 & 0.71 & 0.69 & 4.24 & 0.082 & 8.8 \\
\hline 7245.8 & 58.96 & 0.714 & 19.47 & 5.41 & 0.031 & 1.81 & 0.29 & 0.69 & 4.50 & 0.085 & 6.8 \\
\hline 7247.6 & 59.14 & 0.827 & 17.48 & 5.56 & 0.051 & 2.11 & 1.94 & 0.67 & 3.97 & 0.117 & 6.0 \\
\hline 7249.9 & 57.30 & 0.735 & 19.01 & 5.68 & 0.030 & 1.80 & 0.52 & 0.75 & 4.37 & 0.093 & 8.1 \\
\hline 7252.2 & 55.97 & 0.698 & 18.20 & 5.90 & 0.037 & 1.88 & 2.02 & 0.69 & 4.21 & 0.089 & 7.9 \\
\hline 7255.8 & 55.18 & 0.746 & 20.04 & 5.62 & 0.026 & 1.63 & 0.58 & 0.70 & 4.69 & 0.078 & 8.7 \\
\hline 7258.3 & 50.67 & 0.629 & 17.27 & 10.17 & 0.029 & 1.87 & 1.50 & 0.59 & 3.73 & 0.094 & 10.2 \\
\hline 7261.9 & 56.15 & 0.831 & 18.46 & 6.04 & 0.042 & 1.77 & 1.72 & 0.69 & 4.25 & 0.081 & 7.7 \\
\hline 7264.6 & 54.76 & 0.791 & 18.32 & 6.38 & 0.037 & 1.71 & 1.53 & 0.65 & 4.24 & 0.097 & 8.9 \\
\hline 7267.8 & 55.53 & 0.806 & 19.15 & 6.23 & 0.030 & 1.66 & 0.42 & 0.68 & 4.41 & 0.087 & 9.1 \\
\hline 7270.3 & 56.52 & 0.860 & 19.29 & 6.04 & 0.028 & 1.64 & 0.28 & 0.68 & 4.45 & 0.088 & 8.2 \\
\hline 7272.7 & 53.82 & 0.788 & 18.18 & 7.38 & 0.037 & 1.62 & 0.48 & 0.66 & 4.20 & 0.085 & 10.7 \\
\hline 7275.9 & 56.90 & 0.832 & 18.98 & 5.63 & 0.029 & 1.70 & 0.44 & 0.71 & 4.36 & 0.083 & 8.3 \\
\hline 7278.6 & 55.46 & 0.828 & 18.48 & 5.95 & 0.029 & 1.68 & 0.60 & 0.66 & 4.25 & 0.087 & 9.9 \\
\hline 7281.7 & 51.69 & 0.739 & 16.99 & 6.34 & 0.048 & 1.91 & 4.83 & 0.54 & 3.91 & 0.112 & 7.5 \\
\hline 7284.7 & 56.36 & 0.866 & 18.95 & 5.91 & 0.028 & 1.71 & 0.41 & 0.67 & 4.34 & 0.089 & 8.4 \\
\hline 7287.8 & 57.74 & 0.842 & 19.23 & 5.77 & 0.031 & 1.80 & 0.45 & 0.72 & 4.36 & 0.090 & 6.9 \\
\hline 7290.5 & 55.36 & 0.815 & 18.25 & 6.19 & 0.033 & 1.78 & 0.76 & 0.68 & 4.16 & 0.091 & 9.2 \\
\hline 7296.9 & 56.54 & 0.826 & 18.66 & 6.31 & 0.033 & 1.84 & 0.77 & 0.65 & 4.25 & 0.095 & 7.5 \\
\hline 7299.9 & 57.29 & 0.816 & 18.50 & 5.87 & 0.029 & 1.70 & 0.48 & 0.65 & 4.28 & 0.084 & 8.2 \\
\hline 7303 & 57.61 & 0.819 & 18.46 & 5.91 & 0.032 & 1.79 & 0.83 & 0.63 & 4.27 & 0.094 & 7.0 \\
\hline 7305.8 & 55.11 & 0.804 & 17.91 & 6.49 & 0.041 & 1.90 & 2.20 & 0.62 & 4.13 & 0.092 & 7.1 \\
\hline 7309.2 & 56.55 & 0.823 & 18.84 & 6.31 & 0.034 & 1.83 & 0.73 & 0.67 & 4.28 & 0.092 & 7.8 \\
\hline 7311.9 & 56.94 & 0.804 & 18.70 & 6.59 & 0.043 & 2.11 & 1.33 & 0.62 & 4.20 & 0.088 & 6.0 \\
\hline 7314.7 & 57.16 & 0.847 & 18.52 & 5.80 & 0.032 & 1.69 & 0.63 & 0.65 & 4.27 & 0.083 & 8.2 \\
\hline 7317.8 & 56.85 & 0.868 & 18.37 & 5.77 & 0.032 & 1.69 & 0.86 & 0.64 & 4.25 & 0.096 & 8.4 \\
\hline 7320.7 & 56.71 & 0.856 & 18.88 & 5.86 & 0.032 & 1.75 & 0.81 & 0.63 & 4.34 & 0.094 & 7.6 \\
\hline 7323.5 & 56.49 & 0.849 & 18.82 & 5.88 & 0.031 & 1.69 & 0.59 & 0.66 & 4.34 & 0.097 & 8.4 \\
\hline 7326.7 & 57.02 & 0.845 & 19.01 & 5.72 & 0.042 & 1.95 & 1.55 & 0.61 & 4.37 & 0.089 & 6.0 \\
\hline 7330.3 & 56.73 & 0.823 & 19.33 & 5.60 & 0.035 & 1.73 & 1.36 & 0.66 & 4.46 & 0.089 & 6.4 \\
\hline
\end{tabular}




\begin{tabular}{cccccccccccc}
\hline $\mathbf{7 3 3 3 . 1}$ & 55.46 & 0.811 & 19.80 & 5.46 & 0.044 & 1.95 & 2.10 & 0.62 & 4.56 & 0.085 & 6.0 \\
$\mathbf{7 3 3 6 . 5}$ & 50.76 & 0.767 & 15.99 & 6.24 & 0.072 & 2.16 & 6.85 & 0.48 & 3.66 & 0.114 & 8.9 \\
$\mathbf{7 3 3 8 . 9}$ & 56.77 & 0.773 & 18.27 & 5.65 & 0.032 & 1.61 & 1.14 & 0.65 & 4.29 & 0.095 & 8.1 \\
$\mathbf{7 3 4 2 . 3}$ & 56.98 & 0.698 & 16.70 & 5.39 & 0.026 & 1.48 & 0.97 & 0.62 & 3.93 & 0.090 & 11.9 \\
$\mathbf{7 3 4 4 . 9}$ & 59.41 & 0.688 & 17.05 & 5.10 & 0.026 & 1.52 & 1.07 & 0.64 & 4.01 & 0.083 & 8.9 \\
$\mathbf{7 3 4 7 . 8}$ & 59.10 & 0.769 & 17.57 & 4.97 & 0.024 & 1.47 & 0.48 & 0.64 & 4.13 & 0.080 & 9.3 \\
$\mathbf{7 3 5 1}$ & 58.76 & 0.710 & 17.53 & 5.53 & 0.026 & 1.52 & 0.97 & 0.60 & 4.16 & 0.084 & 8.2 \\
$\mathbf{7 3 5 4 . 4}$ & 10.77 & 0.122 & 2.76 & 5.28 & 0.177 & 1.62 & 35.61 & 0.06 & 0.44 & 0.185 & 28.4 \\
$\mathbf{7 3 5 7 . 3}$ & 57.96 & 0.652 & 16.84 & 5.71 & 0.022 & 1.47 & 0.97 & 0.58 & 3.99 & 0.086 & 10.4 \\
$\mathbf{7 3 6 0 . 5}$ & 58.70 & 0.605 & 14.94 & 5.04 & 0.033 & 1.48 & 3.00 & 0.56 & 3.55 & 0.092 & 9.1 \\
$\mathbf{7 3 6 3 . 4}$ & 58.06 & 0.627 & 15.74 & 4.99 & 0.026 & 1.48 & 2.28 & 0.57 & 3.71 & 0.083 & 10.4 \\
$\mathbf{7 3 6 6 . 9}$ & 59.80 & 0.648 & 16.17 & 4.82 & 0.022 & 1.42 & 1.34 & 0.58 & 3.83 & 0.073 & 9.2 \\
$\mathbf{7 3 6 9 . 9}$ & 59.16 & 0.636 & 16.02 & 5.01 & 0.023 & 1.42 & 1.44 & 0.61 & 3.79 & 0.088 & 10.0 \\
$\mathbf{7 3 7 3 . 1}$ & 58.31 & 0.671 & 17.00 & 5.39 & 0.020 & 1.39 & 0.53 & 0.60 & 4.03 & 0.072 & 10.0 \\
$\mathbf{7 3 7 7 . 2}$ & 59.56 & 0.631 & 15.77 & 6.35 & 0.020 & 1.35 & 0.62 & 0.59 & 3.71 & 0.081 & 9.6 \\
$\mathbf{7 3 8 1 . 1}$ & 54.54 & 0.608 & 16.79 & 6.56 & 0.034 & 1.81 & 3.22 & 0.56 & 3.91 & 0.084 & 9.3 \\
$\mathbf{7 3 8 3 . 2}$ & 58.70 & 0.685 & 16.76 & 6.13 & 0.020 & 1.35 & 0.30 & 0.63 & 3.95 & 0.070 & 9.8 \\
$\mathbf{7 3 8 5 . 7}$ & 56.60 & 0.691 & 16.85 & 6.12 & 0.019 & 1.36 & 0.26 & 0.62 & 3.97 & 0.064 & 11.9 \\
$\mathbf{7 3 8 8 . 1}$ & 41.79 & 0.581 & 14.65 & 9.40 & 0.039 & 1.45 & 8.28 & 0.44 & 3.51 & 0.061 & 10.1 \\
$\mathbf{7 3 9 1 . 2}$ & 53.94 & 0.633 & 16.33 & 6.60 & 0.018 & 1.36 & 0.50 & 0.59 & 3.92 & 0.077 & 13.6 \\
$\mathbf{7 3 9 4 . 2}$ & 51.41 & 0.696 & 18.11 & 6.00 & 0.017 & 1.43 & 0.36 & 0.54 & 4.38 & 0.078 & 15.2 \\
$\mathbf{7 3 9 7 . 8}$ & 49.83 & 0.594 & 16.86 & 8.34 & 0.022 & 1.42 & 2.10 & 0.53 & 4.05 & 0.072 & 13.3 \\
\hline \hline MF Average & $\mathbf{5 5 . 5 2}$ & $\mathbf{0 . 7 3}$ & $\mathbf{1 7 . 5 6}$ & $\mathbf{5 . 9 4}$ & $\mathbf{0 . 0 3}$ & $\mathbf{1 . 6 9}$ & $\mathbf{2 . 0 1}$ & $\mathbf{0 . 6 3}$ & $\mathbf{4 . 0 7}$ & $\mathbf{0 . 0 9}$ & $\mathbf{9 . 1 5}$ \\
\hline
\end{tabular}


APPENDIX X. Table summarizing weathering proxies, major element ratios, loss on ignition data, and averages of each from the MIP-3H well. Samples in brown were collected from the Mahantango Formation (MF), whereas the samples in blue were collected from the Marcellus Shale (MS).

\begin{tabular}{|c|c|c|c|c|c|c|}
\hline Sample & CIA & CIW & ICV & $\mathbf{S i} / \mathbf{A l}$ & Ti/Al & LOI \\
\hline 7447.20 & 70.33 & 86.09 & 0.82 & 3.54 & 0.042 & 9.20 \\
\hline 7448.35 & 73.27 & 90.51 & 0.76 & 3.37 & 0.042 & 9.60 \\
\hline 7449.25 & 73.33 & 90.57 & 0.81 & 3.28 & 0.042 & 9.49 \\
\hline 7450.20 & 72.70 & 89.66 & 0.78 & 3.55 & 0.042 & 8.90 \\
\hline 7452.22 & 73.15 & 90.38 & 0.81 & 3.82 & 0.043 & 8.58 \\
\hline 7455.00 & 27.01 & 28.65 & 2.35 & 3.29 & 0.044 & 13.52 \\
\hline 7456.16 & 72.99 & 90.12 & 0.74 & 2.81 & 0.039 & 11.90 \\
\hline 7457.15 & 72.08 & 88.83 & 0.80 & 3.24 & 0.041 & 10.49 \\
\hline 7457.37 & 68.94 & 84.37 & 0.92 & 3.81 & 0.041 & 9.24 \\
\hline 7459.13 & 73.10 & 89.98 & 0.80 & 2.84 & 0.038 & - \\
\hline 7460.20 & 74.13 & 91.69 & 0.72 & 2.80 & 0.037 & - \\
\hline 7463.10 & 73.33 & 90.66 & 0.70 & 2.92 & 0.040 & 9.81 \\
\hline 7464.05 & 68.02 & 82.82 & 0.78 & 2.87 & 0.038 & 10.94 \\
\hline 7465.30 & 71.76 & 88.27 & 0.82 & 2.98 & 0.038 & 12.14 \\
\hline 7467.30 & 27.65 & 29.75 & 2.12 & 2.93 & 0.037 & 15.88 \\
\hline 7470.05 & 73.04 & 90.22 & 0.70 & 2.89 & 0.036 & - \\
\hline 7471.13 & 64.96 & 78.58 & 0.85 & 3.03 & 0.037 & 12.08 \\
\hline 7472.09 & 72.98 & 90.57 & 0.73 & 2.84 & 0.037 & 12.89 \\
\hline 7475.12 & 68.37 & 83.40 & 0.81 & 2.81 & 0.038 & 12.93 \\
\hline 7476.15 & 62.79 & 75.46 & 0.89 & 2.80 & 0.037 & 11.64 \\
\hline 7477.07 & 64.51 & 77.83 & 0.97 & 2.85 & 0.039 & 11.78 \\
\hline 7479.05 & 71.39 & 87.83 & 0.72 & 2.96 & 0.039 & 10.75 \\
\hline 7480.05 & 71.93 & 88.73 & 0.70 & 3.07 & 0.042 & 9.53 \\
\hline 7482.12 & 20.73 & 21.89 & 2.98 & 3.55 & 0.040 & - \\
\hline 7484.11 & 72.35 & 89.71 & 0.69 & 3.24 & 0.041 & 10.76 \\
\hline 7485.03 & 71.70 & 88.77 & 0.70 & 3.24 & 0.041 & 10.35 \\
\hline 7485.60 & 72.14 & 89.44 & 0.74 & 3.28 & 0.041 & 9.79 \\
\hline 7488.15 & 67.70 & 83.02 & 0.80 & 3.33 & 0.043 & 9.85 \\
\hline 7489.06 & 69.50 & 85.39 & 0.80 & 3.21 & 0.042 & 9.77 \\
\hline 7491.22 & 69.54 & 85.44 & 0.78 & 3.13 & 0.043 & 10.81 \\
\hline 7492.06 & 68.62 & 83.78 & 0.83 & 3.09 & 0.039 & - \\
\hline 7494.20 & 67.14 & 81.99 & 0.78 & 3.25 & 0.040 & 11.32 \\
\hline 7497.39 & 50.16 & 58.14 & 1.41 & 3.37 & 0.041 & 11.54 \\
\hline 7500.60 & 48.52 & 56.12 & 1.29 & 4.47 & 0.043 & 12.30 \\
\hline 7503.04 & 53.33 & 62.62 & 1.17 & 5.51 & 0.043 & 13.37 \\
\hline 7503.98 & 53.60 & 62.73 & 1.15 & 5.58 & 0.043 & - \\
\hline 7505.93 & 66.44 & 81.42 & 1.10 & 4.69 & 0.046 & 13.20 \\
\hline 7506.99 & 63.12 & 76.63 & 0.95 & 4.86 & 0.044 & 13.58 \\
\hline
\end{tabular}




\begin{tabular}{|c|c|c|c|c|c|c|}
\hline 7509.01 & 28.30 & 30.79 & 2.42 & 5.57 & 0.044 & 11.23 \\
\hline 7512.01 & 61.99 & 74.44 & 1.08 & 5.19 & 0.043 & - \\
\hline 7513.08 & 53.54 & 63.07 & 1.19 & 4.67 & 0.045 & 17.50 \\
\hline 7514.10 & 55.16 & 65.32 & 1.12 & 4.81 & 0.046 & 15.32 \\
\hline 7515.80 & 51.64 & 60.48 & 1.14 & 4.01 & 0.047 & 12.25 \\
\hline 7517.23 & 42.24 & 48.01 & 1.30 & 4.14 & 0.046 & 11.87 \\
\hline 7519.05 & 43.46 & 49.37 & 1.62 & 3.85 & 0.047 & - \\
\hline 7520.13 & 49.07 & 57.07 & 1.22 & 3.77 & 0.050 & 14.91 \\
\hline 7522.05 & 57.25 & 68.25 & 0.95 & 3.57 & 0.051 & 14.41 \\
\hline 7523.03 & 48.26 & 56.03 & 1.00 & 3.33 & 0.049 & 11.59 \\
\hline 7523.89 & 1.40 & 1.41 & 41.41 & 5.96 & 0.052 & 33.37 \\
\hline 7524.90 & 36.52 & 40.78 & 1.41 & 3.62 & 0.053 & 12.97 \\
\hline 7528.01 & 48.39 & 56.18 & 1.17 & 4.12 & 0.047 & - \\
\hline 7530.15 & 58.44 & 70.59 & 1.14 & 4.39 & 0.046 & 13.24 \\
\hline 7533.02 & 42.69 & 48.86 & 1.34 & 4.18 & 0.045 & 13.25 \\
\hline 7534.04 & 47.39 & 55.03 & 1.19 & 4.18 & 0.045 & 13.34 \\
\hline 7534.89 & 61.01 & 74.23 & 0.91 & 4.55 & 0.046 & 12.58 \\
\hline 7538.15 & 62.52 & 76.49 & 1.02 & 3.89 & 0.041 & - \\
\hline 7542.93 & 16.91 & 17.79 & 3.76 & 6.29 & 0.044 & 18.58 \\
\hline 7544.37 & 38.28 & 43.02 & 2.10 & 5.32 & 0.039 & 14.47 \\
\hline 7544.85 & 43.09 & 49.22 & 2.25 & 5.43 & 0.043 & 17.30 \\
\hline 7545.77 & 46.01 & 53.56 & 1.79 & 5.53 & 0.042 & 22.42 \\
\hline 7554.33 & 0.68 & 0.68 & 81.99 & 44.14 & 0.025 & 33.73 \\
\hline 7556.15 & 34.11 & 38.24 & 1.80 & 5.12 & 0.048 & 16.31 \\
\hline MF Avg & 72.55 & 89.44 & 0.79 & 3.51 & 0.042 & 9.16 \\
\hline MS Avg & 54.77 & 65.68 & 3.33 & 4.58 & 0.042 & 13.68 \\
\hline
\end{tabular}


APPENDIX XI. Table summarizing weathering proxies, major element ratios, loss on ignition data, and averages of each from the WV-6 well. Samples in brown were collected from the Mahantango Formation, whereas the sample in blue was collected from the Marcellus Shale.

\begin{tabular}{|c|c|c|c|c|c|c|}
\hline Sample & CIA & CIW & ICV & Si/Al & Ti/Al & LOI \\
\hline 7222.3 & 56.59 & 65.78 & 0.95 & 3.23 & 0.042 & 7.56 \\
\hline 7225.3 & 69.47 & 84.04 & 0.79 & 3.02 & 0.042 & 7.87 \\
\hline 7228.1 & 73.34 & 89.33 & 0.69 & 2.79 & 0.033 & 12.35 \\
\hline 7229.9 & 74.05 & 90.72 & 0.76 & 3.83 & 0.037 & 8.14 \\
\hline 7233.3 & 55.08 & 64.02 & 1.00 & 3.25 & 0.038 & 7.97 \\
\hline 7237.3 & 70.87 & 86.02 & 0.81 & 3.38 & 0.046 & 5.94 \\
\hline 7240.2 & 73.06 & 89.61 & 0.86 & 3.16 & 0.037 & 12.63 \\
\hline 7244.4 & 72.13 & 88.21 & 0.73 & 3.21 & 0.037 & 8.75 \\
\hline 7245.8 & 74.85 & 92.12 & 0.69 & 3.03 & 0.037 & 6.80 \\
\hline 7247.6 & 66.22 & 79.10 & 0.87 & 3.38 & 0.047 & 5.98 \\
\hline 7249.9 & 73.33 & 89.71 & 0.73 & 3.01 & 0.039 & 8.05 \\
\hline 7252.2 & 66.04 & 79.12 & 0.85 & 3.08 & 0.038 & 7.92 \\
\hline 7255.8 & 73.34 & 90.09 & 0.70 & 2.75 & 0.037 & 8.66 \\
\hline 7258.3 & 69.05 & 82.37 & 1.07 & 2.93 & 0.036 & 10.23 \\
\hline 7261.9 & 67.61 & 81.29 & 0.83 & 3.04 & 0.045 & 7.74 \\
\hline 7264.6 & 68.45 & 82.64 & 0.84 & 2.99 & 0.043 & 8.89 \\
\hline 7267.8 & 74.23 & 91.06 & 0.74 & 2.90 & 0.042 & 9.12 \\
\hline 7270.3 & 74.96 & 92.23 & 0.72 & 2.93 & 0.045 & 8.17 \\
\hline 7272.7 & 73.66 & 90.28 & 0.83 & 2.96 & 0.043 & 10.71 \\
\hline 7275.9 & 73.93 & 90.57 & 0.72 & 3.00 & 0.044 & 8.35 \\
\hline 7278.6 & 73.19 & 89.50 & 0.76 & 3.00 & 0.045 & 9.91 \\
\hline 7281.7 & 55.00 & 63.73 & 1.08 & 3.04 & 0.044 & 7.48 \\
\hline 7284.7 & 74.37 & 91.18 & 0.73 & 2.97 & 0.046 & 8.39 \\
\hline 7287.8 & 74.09 & 90.58 & 0.73 & 3.00 & 0.044 & 6.94 \\
\hline 7290.5 & 72.26 & 87.95 & 0.79 & 3.03 & 0.045 & 9.15 \\
\hline 7296.9 & 72.52 & 88.29 & 0.79 & 3.03 & 0.044 & 7.54 \\
\hline 7299.9 & 73.78 & 90.52 & 0.75 & 3.10 & 0.044 & 8.19 \\
\hline 7303 & 72.00 & 87.83 & 0.77 & 3.12 & 0.044 & 7.00 \\
\hline 7305.8 & 65.37 & 78.12 & 0.90 & 3.08 & 0.045 & 7.06 \\
\hline 7309.2 & 72.73 & 88.56 & 0.78 & 3.00 & 0.044 & 7.78 \\
\hline 7311.9 & 70.05 & 84.45 & 0.84 & 3.05 & 0.043 & 6.03 \\
\hline 7314.7 & 73.03 & 89.31 & 0.75 & 3.09 & 0.046 & 8.15 \\
\hline 7317.8 & 71.80 & 87.52 & 0.77 & 3.09 & 0.047 & 8.36 \\
\hline 7320.7 & 72.39 & 88.29 & 0.76 & 3.00 & 0.045 & 7.55 \\
\hline 7323.5 & 73.32 & 89.75 & 0.75 & 3.00 & 0.045 & 8.43 \\
\hline 7326.7 & 68.99 & 83.27 & 0.79 & 3.00 & 0.044 & 6.02 \\
\hline 7330.3 & 69.75 & 84.45 & 0.76 & 2.94 & 0.043 & 6.36 \\
\hline
\end{tabular}




\begin{tabular}{ccccccc}
\hline $\mathbf{7 3 3 3 . 1}$ & 66.94 & 80.35 & 0.79 & 2.80 & 0.041 & 6.00 \\
$\mathbf{7 3 3 6 . 5}$ & 48.15 & 54.68 & 1.27 & 3.17 & 0.048 & 8.93 \\
$\mathbf{7 3 3 8 . 9}$ & 70.12 & 85.31 & 0.77 & 3.11 & 0.042 & 8.14 \\
$\mathbf{7 3 4 2 . 3}$ & 70.36 & 85.72 & 0.78 & 3.41 & 0.042 & 11.86 \\
$\mathbf{7 3 4 4 . 9}$ & 69.91 & 85.05 & 0.77 & 3.48 & 0.040 & 8.93 \\
$\mathbf{7 3 4 7 . 8}$ & 73.29 & 90.09 & 0.71 & 3.36 & 0.044 & 9.33 \\
$\mathbf{7 3 5 1}$ & 70.75 & 86.45 & 0.77 & 3.35 & 0.040 & 8.24 \\
$\mathbf{7 3 5 4 . 4}$ & 4.05 & 4.08 & 15.69 & 3.90 & 0.044 & 28.42 \\
$\mathbf{7 3 5 7 . 3}$ & 70.52 & 86.11 & 0.80 & 3.44 & 0.039 & 10.38 \\
$\mathbf{7 3 6 0 . 5}$ & 59.37 & 70.06 & 0.96 & 3.93 & 0.040 & 9.06 \\
$\mathbf{7 3 6 3 . 4}$ & 63.33 & 75.55 & 0.87 & 3.69 & 0.040 & 10.37 \\
$\mathbf{7 3 6 6 . 9}$ & 68.20 & 82.64 & 0.78 & 3.70 & 0.040 & 9.18 \\
$\mathbf{7 3 6 9 . 9}$ & 67.48 & 81.59 & 0.81 & 3.69 & 0.040 & 9.98 \\
$\mathbf{7 3 7 3 . 1}$ & 72.91 & 89.69 & 0.74 & 3.43 & 0.039 & 10.03 \\
$\mathbf{7 3 7 7 . 2}$ & 72.06 & 88.24 & 0.84 & 3.78 & 0.040 & 9.58 \\
$\mathbf{7 3 8 1 . 1}$ & 60.42 & 71.27 & 0.99 & 3.25 & 0.036 & 9.29 \\
$\mathbf{7 3 8 3 . 2}$ & 74.13 & 91.39 & 0.78 & 3.50 & 0.041 & 9.83 \\
$\mathbf{7 3 8 5 . 7}$ & 74.44 & 91.85 & 0.77 & 3.36 & 0.041 & 11.86 \\
$\mathbf{7 3 8 8 . 1}$ & 42.81 & 48.15 & 1.62 & 2.85 & 0.040 & 10.07 \\
$\mathbf{7 3 9 1 . 2}$ & 72.73 & 89.69 & 0.83 & 3.30 & 0.039 & 13.63 \\
$\mathbf{7 3 9 4 . 2}$ & 74.22 & 92.13 & 0.74 & 2.84 & 0.038 & 15.22 \\
$\mathbf{7 3 9 7 . 8}$ & 65.03 & 78.28 & 1.01 & 2.96 & 0.035 & 13.28 \\
\hline $\mathbf{M F}$ & $\mathbf{6 8 . 1 2}$ & $\mathbf{8 2 . 6 2}$ & $\mathbf{1 . 0 8}$ & $\mathbf{3 . 1 9}$ & $\mathbf{0 . 0 4 2}$ & $\mathbf{9 . 1 5}$ \\
$\mathbf{A v e r a g e}$ & & & & & & \\
\hline $\mathbf{7 3 6}$ & & & & & & \\
\hline
\end{tabular}


APPENDIX XII. Trace element concentrations (ppm) of the MIP-3H samples. The Mahantango Formation (MF) is recorded in brown, with the Marcellus Shale (MS) recorded in blue. "ND" indicates elements which could not be determined reliably within the presence of $>3 \mathrm{wt} \%$ barium.

\begin{tabular}{|c|c|c|c|c|c|c|c|c|c|c|c|}
\hline Depth (ft) & $\mathbf{N i}$ & $\mathrm{Cr}$ & V & Sc & $\mathrm{Cu}$ & $\mathbf{Z n}$ & Ga & $\mathbf{B a}$ & $\mathbf{R b}$ & Cs & $\mathbf{S r}$ \\
\hline 7447.20 & 105 & 104 & 398 & 16 & 93 & 41 & 21 & 1496 & 187 & 10 & 124 \\
\hline 7448.35 & 124 & 105 & 441 & 18 & 97 & 36 & 22 & 1172 & 197 & 17 & 130 \\
\hline 7449.25 & 135 & 102 & 385 & 15 & 105 & 41 & 23 & 1382 & 202 & 11 & 124 \\
\hline 7450.20 & 96 & 100 & 361 & 17 & 97 & 33 & 22 & 1278 & 193 & 16 & 119 \\
\hline 7452.22 & 98 & 87 & 315 & 17 & 86 & 35 & 22 & 1185 & 177 & 10 & 111 \\
\hline 7455.00 & 28 & 54 & 111 & 15 & 22 & 29 & 17 & 907 & 105 & 6 & 266 \\
\hline 7456.16 & 170 & 94 & 343 & 21 & 110 & 348 & 26 & 1676 & 219 & 16 & 134 \\
\hline 7457.15 & 179 & 96 & 436 & 19 & 125 & 224 & 23 & 2138 & 200 & 16 & 135 \\
\hline 7457.37 & 135 & 89 & 322 & 18 & 113 & 36 & 20 & 1097 & 181 & 11 & 124 \\
\hline 7459.13 & 165 & 119 & 444 & 19 & 132 & 39 & 25 & 1722 & 222 & 18 & 128 \\
\hline 7460.20 & 165 & 103 & 421 & 20 & 115 & 48 & 27 & 1588 & 228 & 16 & 136 \\
\hline 7463.10 & 118 & 92 & 277 & 19 & 92 & 207 & 27 & 3292 & 225 & 16 & 161 \\
\hline 7464.05 & 144 & 90 & 272 & 20 & 144 & 71 & 25 & 1656 & 217 & 14 & 151 \\
\hline 7465.30 & 144 & 96 & 286 & 15 & 165 & 52 & 24 & 4270 & 206 & 15 & 161 \\
\hline 7467.30 & 104 & 62 & 189 & 15 & 124 & 39 & 20 & 1310 & 145 & 6 & 240 \\
\hline 7470.05 & 153 & 100 & 365 & 18 & 86 & 64 & 27 & 1520 & 229 & 15 & 127 \\
\hline 7471.13 & 180 & 89 & 389 & 18 & 134 & 44 & 23 & 7634 & 200 & 13 & 229 \\
\hline 7472.09 & 198 & 94 & 499 & 19 & 142 & 350 & 26 & 8395 & 217 & 18 & 221 \\
\hline 7475.12 & 184 & 85 & 346 & 17 & 151 & 139 & 26 & 19000 & 204 & 12 & 386 \\
\hline 7476.15 & 163 & 88 & 301 & 22 & 157 & 447 & 24 & 1599 & 215 & 15 & 140 \\
\hline 7477.07 & 155 & 88 & 329 & 23 & 180 & 46 & 25 & 1362 & 208 & 14 & 162 \\
\hline 7479.05 & 160 & 100 & 347 & 20 & 130 & 893 & 25 & 1497 & 210 & 16 & 106 \\
\hline 7480.05 & 118 & 98 & 285 & 19 & 98 & 62 & 25 & 1988 & 214 & 17 & 121 \\
\hline 7482.12 & 52 & 52 & 94 & 7 & 83 & 20 & 13 & 11800 & 103 & 3 & 420 \\
\hline 7484.11 & 142 & 85 & 332 & 19 & 105 & 37 & 25 & 1508 & 206 & 13 & 118 \\
\hline 7485.03 & 121 & 89 & 291 & 19 & 91 & 2965 & 24 & 1502 & 202 & 15 & 117 \\
\hline 7485.60 & 113 & 85 & 254 & 18 & 79 & 75 & 22 & 1587 & 207 & 13 & 118 \\
\hline 7488.15 & 85 & 84 & 189 & 19 & 79 & 43 & 24 & 1560 & 199 & 13 & 118 \\
\hline 7489.06 & 106 & 92 & 217 & 18 & 68 & 37 & 22 & 1430 & 198 & 13 & 122 \\
\hline 7491.22 & 120 & 93 & 250 & 20 & 83 & 34 & 24 & 1669 & 198 & 12 & 130 \\
\hline 7492.06 & 152 & 89 & 220 & 19 & 99 & 102 & 26 & 41600 & 196 & 11 & 605 \\
\hline 7494.20 & 124 & 94 & 282 & 19 & 103 & 71 & 24 & 1379 & 196 & 14 & 126 \\
\hline 7497.39 & 171 & 84 & 291 & 20 & 140 & 62 & 20 & 10000 & 162 & 12 & 281 \\
\hline 7500.60 & 193 & 79 & 448 & 17 & 143 & 446 & 16 & 25700 & 136 & 11 & 435 \\
\hline 7503.04 & 181 & 81 & 477 & 16 & 137 & 270 & 16 & 909 & 126 & 11 & 132 \\
\hline 7503.98 & 177 & 73 & 461 & 14 & 134 & 877 & 16 & 1110 & 123 & 10 & 125 \\
\hline 7505.93 & 154 & 80 & 412 & 15 & 134 & 55 & 17 & 1108 & 146 & 14 & 112 \\
\hline 7506.99 & 166 & 78 & 459 & 14 & 139 & 31 & 18 & 1025 & 143 & 12 & 118 \\
\hline 7509.01 & 175 & 56 & 261 & 17 & 148 & 50 & 14 & 1000 & 107 & 7 & 192 \\
\hline 7512.01 & 77 & 81 & 507 & 15 & 51 & 31 & 16 & 1170 & 127 & 7 & 122 \\
\hline 7513.08 & 224 & 81 & 622 & 19 & 142 & 436 & 16 & 1069 & 132 & 10 & 137 \\
\hline 7514.10 & 188 & 81 & 529 & 17 & 147 & 35 & 17 & 995 & 135 & 9 & 146 \\
\hline 7515.80 & 207 & 85 & 472 & 18 & 136 & 27 & 20 & 1048 & 155 & 10 & 171 \\
\hline 7517.23 & 196 & 91 & 661 & 20 & 154 & 183 & 19 & 1085 & 139 & 12 & 257 \\
\hline
\end{tabular}




\begin{tabular}{cccccccccccc}
\hline $\mathbf{7 5 1 9 . 0 5}$ & 189 & 99 & 665 & 15 & 153 & 26 & 22 & 59000 & 131 & 7 & 751 \\
$\mathbf{7 5 2 0 . 1 3}$ & 190 & 130 & 732 & 23 & 187 & 696 & 20 & 1248 & 151 & 12 & 146 \\
$\mathbf{7 5 2 2 . 0 5}$ & 199 & 123 & 656 & 21 & 197 & 135 & 20 & 1590 & 159 & 11 & 147 \\
$\mathbf{7 5 2 3 . 0 3}$ & 120 & 121 & 404 & 22 & 130 & 130 & 21 & 1760 & 171 & 10 & 211 \\
$\mathbf{7 5 2 3 . 8 9}$ & 46 & 0 & 17 & 0 & 35 & 29 & $\mathrm{ND}$ & 70200 & 9 & $\mathrm{ND}$ & 1064 \\
$\mathbf{7 5 2 4 . 9 0}$ & 84 & 107 & 224 & 19 & 113 & 378 & 19 & 1568 & 141 & 11 & 282 \\
$\mathbf{7 5 2 8 . 0 1}$ & 160 & 93 & 563 & 16 & 88 & 22 & 18 & 1098 & 151 & 6 & 164 \\
$\mathbf{7 5 3 0 . 1 5}$ & 179 & 72 & 510 & 14 & 103 & 25 & 19 & 26800 & 143 & 7 & 464 \\
$\mathbf{7 5 3 3 . 0 2}$ & 188 & 88 & 571 & 18 & 107 & 247 & 19 & 1149 & 148 & 10 & 207 \\
$\mathbf{7 5 3 4 . 0 4}$ & 166 & 78 & 491 & 17 & 99 & 146 & 19 & 1531 & 149 & 11 & 182 \\
$\mathbf{7 5 3 4 . 8 9}$ & 169 & 90 & 492 & 17 & 102 & 243 & 18 & 1022 & 148 & 12 & 128 \\
$\mathbf{7 5 3 8 . 1 5}$ & 323 & 108 & 1106 & 17 & 161 & 1435 & 20 & 1253 & 156 & 13 & 124 \\
$\mathbf{7 5 4 2 . 9 3}$ & 251 & 61 & 713 & 14 & 151 & 1129 & 10 & 804 & 68 & 5 & 332 \\
$\mathbf{7 5 4 4 . 3 7}$ & 243 & 23 & 889 & 8 & 166 & 121 & $\mathrm{ND}$ & 172000 & 58 & $\mathrm{ND}$ & 2224 \\
$\mathbf{7 5 4 4 . 8 5}$ & 220 & 40 & 777 & 7 & 173 & 57 & $\mathrm{ND}$ & 128000 & 68 & $\mathrm{ND}$ & 1676 \\
$\mathbf{7 5 4 5 . 7 7}$ & 466 & 102 & 1274 & 13 & 231 & 986 & 16 & 1193 & 99 & 5 & 158 \\
$\mathbf{7 5 5 4 . 3 3}$ & 21 & 0 & 52 & 0 & 6 & 53 & 0 & 102 & 3 & 0 & 261 \\
$\mathbf{7 5 5 6 . 1 5}$ & 304 & 89 & 1083 & 14 & 224 & 257 & 16 & 930 & 116 & 9 & 248 \\
\hline \hline MS Avg. & 163 & 84 & 437 & 17 & 124 & 266 & 20 & 11301 & 159 & 11 & 281 \\
MF Avg. & 112 & 100 & 380 & 16 & 96 & 37 & 22 & 1303 & 191 & 13 & 121 \\
\hline
\end{tabular}

\begin{tabular}{lrrrrrrrrrrr}
\hline Depth (ft) & \multicolumn{1}{c}{ Y } & $\mathbf{Z r}$ & $\mathbf{H f}$ & $\mathbf{N b}$ & $\mathbf{M o}$ & $\mathbf{L a}$ & $\mathbf{C e}$ & $\mathbf{N d}$ & $\mathbf{T h}$ & $\mathbf{U}$ & $\mathbf{P b} \geq$ \\
\hline $\mathbf{7 4 4 7 . 2 0}$ & 36 & 119 & 2 & 11 & 32 & 39 & 77 & 36 & 11 & 8 & 31 \\
$\mathbf{7 4 4 8 . 3 5}$ & 31 & 122 & 5 & 11 & 56 & 40 & 75 & 31 & 12 & 9 & 29 \\
$\mathbf{7 4 4 9 . 2 5}$ & 32 & 124 & 4 & 12 & 53 & 38 & 71 & 32 & 12 & 8 & 33 \\
$\mathbf{7 4 5 0 . 2 0}$ & 31 & 120 & 3 & 12 & 25 & 37 & 71 & 36 & 11 & 6 & 32 \\
$\mathbf{7 4 5 2 . 2 2}$ & 27 & 114 & 4 & 10 & 26 & 34 & 71 & 27 & 13 & 7 & 33 \\
$\mathbf{7 4 5 5 . 0 0}$ & 76 & 106 & 3 & 11 & 3 & 48 & 94 & 47 & 7 & 4 & 7 \\
$\mathbf{7 4 5 6 . 1 6}$ & 29 & 127 & 4 & 13 & 119 & 39 & 65 & 30 & 12 & 15 & 26 \\
$\mathbf{7 4 5 7 . 1 5}$ & 32 & 116 & 4 & 9 & 89 & 35 & 69 & 30 & 13 & 13 & 36 \\
$\mathbf{7 4 5 7 . 3 7}$ & 32 & 109 & 4 & 11 & 53 & 33 & 68 & 32 & 11 & 7 & 33 \\
$\mathbf{7 4 5 9 . 1 3}$ & 33 & 124 & 4 & 11 & 72 & 37 & 72 & 36 & 12 & 17 & 24 \\
$\mathbf{7 4 6 0 . 2 0}$ & 37 & 124 & 4 & 12 & 107 & 39 & 78 & 37 & 11 & 19 & 26 \\
$\mathbf{7 4 6 3 . 1 0}$ & 38 & 124 & 5 & 12 & 95 & 43 & 76 & 41 & 13 & 16 & 30 \\
$\mathbf{7 4 6 4 . 0 5}$ & 35 & 119 & 3 & 11 & 90 & 42 & 83 & 36 & 13 & 16 & 32 \\
$\mathbf{7 4 6 5 . 3 0}$ & 30 & 118 & 3 & 12 & 99 & 38 & 69 & 30 & 11 & 20 & 33 \\
$\mathbf{7 4 6 7 . 3 0}$ & 123 & 88 & 2 & 9 & 94 & 51 & 97 & 57 & 9 & 23 & 19 \\
$\mathbf{7 4 7 0 . 0 5}$ & 26 & 116 & 3 & 11 & 110 & 34 & 64 & 31 & 11 & 21 & 23 \\
$\mathbf{7 4 7 1 . 1 3}$ & 32 & 109 & 1 & 9 & 155 & 36 & 71 & 34 & 12 & 17 & 31 \\
$\mathbf{7 4 7 2 . 0 9}$ & 30 & 115 & 3 & 11 & 143 & 35 & 79 & 34 & 13 & 24 & 31 \\
$\mathbf{7 4 7 5 . 1 2}$ & 63 & 111 & 3 & 11 & 129 & 40 & 92 & 57 & 11 & 30 & 33 \\
$\mathbf{7 4 7 6 . 1 5}$ & 35 & 111 & 2 & 10 & 111 & 38 & 74 & 40 & 11 & 22 & 32 \\
$\mathbf{7 4 7 7 . 0 7}$ & 33 & 115 & 4 & 12 & 99 & 40 & 88 & 36 & 13 & 19 & 35 \\
$\mathbf{7 4 7 9 . 0 5}$ & 23 & 111 & 4 & 11 & 121 & 36 & 68 & 30 & 12 & 15 & 29 \\
$\mathbf{7 4 8 0 . 0 5}$ & 26 & 122 & 5 & 12 & 59 & 35 & 66 & 26 & 11 & 11 & 27 \\
$\mathbf{7 4 8 2 . 1 2}$ & 62 & 74 & 3 & 7 & 12 & 24 & 52 & 29 & 5 & 7 & 18 \\
$\mathbf{7 4 8 4 . 1 1}$ & 28 & 117 & 4 & 11 & 114 & 34 & 67 & 29 & 14 & 15 & 27 \\
$\mathbf{7 4 8 5 . 0 3}$ & 31 & 114 & 4 & 10 & 105 & 34 & 68 & 33 & 10 & 15 & 26 \\
$\mathbf{7 4 8 5 . 6 0}$ & 29 & 116 & 4 & 11 & 97 & 34 & 68 & 34 & 13 & 16 & 28 \\
\hline $\mathbf{7}$ & & & & & & & & & & &
\end{tabular}




\begin{tabular}{|c|c|c|c|c|c|c|c|c|c|c|c|}
\hline 7488.15 & 31 & 123 & 3 & 11 & 91 & 40 & 72 & 36 & 12 & 10 & 23 \\
\hline 7489.06 & 32 & 118 & 4 & 10 & 94 & 35 & 76 & 31 & 13 & 11 & 27 \\
\hline 7491.22 & 35 & 131 & 5 & 12 & 112 & 34 & 78 & 34 & 10 & 14 & 24 \\
\hline 7492.06 & 35 & 116 & 3 & 12 & 107 & 29 & 64 & 29 & 11 & 16 & 19 \\
\hline 7494.20 & 35 & 123 & 5 & 12 & 116 & 32 & 65 & 30 & 11 & 14 & 27 \\
\hline 7497.39 & 43 & 110 & 4 & 11 & 129 & 35 & 68 & 40 & 9 & 28 & 37 \\
\hline 7500.60 & 38 & 105 & 4 & 9 & 153 & 30 & 73 & 29 & 9 & 24 & 33 \\
\hline 7503.04 & 39 & 97 & 2 & 8 & 146 & 30 & 55 & 33 & 9 & 24 & 26 \\
\hline 7503.98 & 38 & 94 & 4 & 7 & 137 & 28 & 52 & 31 & 7 & 23 & 7 \\
\hline 7505.93 & 39 & 107 & 3 & 9 & 133 & 37 & 65 & 34 & 9 & 23 & 34 \\
\hline 7506.99 & 40 & 107 & 3 & 9 & 181 & 29 & 62 & 35 & 10 & 21 & 32 \\
\hline 7509.01 & 108 & 90 & 3 & 7 & 177 & 37 & 79 & 61 & 6 & 47 & 36 \\
\hline 7512.01 & 45 & 104 & 4 & 9 & 132 & 33 & 59 & 36 & 9 & 47 & 5 \\
\hline 7513.08 & 48 & 108 & 3 & 8 & 266 & 32 & 56 & 36 & 9 & 46 & 26 \\
\hline 7514.10 & 50 & 107 & 3 & 9 & 179 & 34 & 64 & 40 & 10 & 31 & 34 \\
\hline 7515.80 & 33 & 123 & 4 & 11 & 181 & 34 & 57 & 30 & 11 & 25 & 33 \\
\hline 7517.23 & 37 & 120 & 3 & 10 & 148 & 35 & 63 & 31 & 8 & 14 & 30 \\
\hline 7519.05 & 28 & 121 & 2 & 12 & 114 & 21 & 45 & 21 & 5 & 15 & 20 \\
\hline 7520.13 & 31 & 159 & 6 & 12 & 129 & 30 & 55 & 29 & 9 & 17 & 29 \\
\hline 7522.05 & 31 & 168 & 4 & 12 & 97 & 36 & 74 & 34 & 11 & 18 & 36 \\
\hline 7523.03 & 37 & 153 & 4 & 13 & 21 & 42 & 83 & 40 & 11 & 10 & 18 \\
\hline 7523.89 & 21 & 16 & 1 & 5 & 10 & 9 & ND & ND & 0 & 1 & ND \\
\hline 7524.90 & 46 & 158 & 5 & 14 & 6 & 40 & 81 & 40 & 12 & 5 & 11 \\
\hline 7528.01 & 37 & 114 & 3 & 9 & 75 & 37 & 63 & 31 & 9 & 16 & 12 \\
\hline 7530.15 & 25 & 95 & 3 & 10 & 91 & 24 & 65 & 21 & 8 & 18 & 37 \\
\hline 7533.02 & 38 & 103 & 3 & 8 & 126 & 34 & 61 & 27 & 9 & 16 & 27 \\
\hline 7534.04 & 33 & 100 & 3 & 10 & 106 & 38 & 57 & 28 & 8 & 18 & 24 \\
\hline 7534.89 & 32 & 102 & 3 & 9 & 120 & 29 & 54 & 28 & 10 & 28 & 28 \\
\hline 7538.15 & 38 & 110 & 3 & 9 & 225 & 29 & 52 & 31 & 9 & 60 & 17 \\
\hline 7542.93 & 84 & 70 & 2 & 7 & 130 & 38 & 64 & 43 & 4 & 44 & 26 \\
\hline 7544.37 & 29 & 40 & 1 & 11 & 101 & 3 & ND & ND & 8 & 28 & ND \\
\hline 7544.85 & 37 & 55 & 3 & 9 & 80 & 10 & ND & ND & 6 & 33 & ND \\
\hline 7545.77 & 46 & 93 & 2 & 5 & 317 & 27 & 46 & 32 & 7 & 71 & 41 \\
\hline 7554.33 & 54 & 1 & 0 & 1 & 24 & 15 & 32 & 26 & 1 & 7 & 2 \\
\hline 7556.15 & 31 & 122 & 3 & 8 & 308 & 17 & 29 & 16 & 7 & 32 & 34 \\
\hline MS Avg. & 40 & 108 & 3 & 10 & 116 & 33 & 67 & 34 & $\overline{99}$ & 21 & 26 \\
\hline MF Avg. & 31 & 120 & 3 & 11 & 39 & 38 & 73 & 33 & 12 & 8 & 32 \\
\hline
\end{tabular}


APPENDIX XIII. Trace element concentrations (ppm) of the WV-6 samples. The Mahantango Formation (MF) is recorded in brown, with the Marcellus Shale recorded in blue.

\begin{tabular}{|c|c|c|c|c|c|c|c|c|c|c|c|}
\hline Depth (ft) & $\mathbf{N i}$ & $\mathrm{Cr}$ & $\bar{V}$ & Sc & $\mathbf{C u}$ & $\mathbf{Z n}$ & Ga & $\mathbf{B a}$ & $\mathbf{R b}$ & Cs & $\mathrm{Sr}$ \\
\hline 7222.3 & 48.3 & 112.2 & 163.2 & 18.2 & 32.7 & 49.1 & 23.8 & 855.1 & 176.3 & 9.1 & 148.8 \\
\hline 7225.3 & 92.0 & 117.6 & 304.4 & 18.0 & 72.3 & 1511.5 & 24.8 & 874.6 & 196.3 & 13.6 & 117.3 \\
\hline 7228.1 & 100.2 & 149.4 & 657.5 & 18.2 & 113.7 & 83.1 & 23.9 & 978.8 & 199.0 & 13.5 & 126.1 \\
\hline 7229.9 & 119.5 & 108.2 & 420.7 & 16.0 & 79.7 & 42.6 & 23.2 & 797.5 & 172.3 & 12.1 & 102.3 \\
\hline 7233.3 & 81.2 & 101.9 & 223.6 & 18.5 & 53.1 & 84.8 & 21.7 & 813.9 & 177.2 & 11.9 & 110.8 \\
\hline 7237.3 & 59.2 & 110.1 & 196.5 & 17.9 & 30.8 & 60.9 & 24.8 & 823.9 & 184.1 & 10.7 & 102.6 \\
\hline 7240.2 & 141.4 & 124.3 & 240.3 & 16.3 & 66.1 & 58.6 & 24.6 & 867.8 & 189.3 & 12.2 & 99.0 \\
\hline 7244.4 & 104.6 & 121.1 & 536.1 & 18.1 & 56.3 & 118.9 & 24.7 & 878.2 & 197.0 & 12.0 & 105.6 \\
\hline 7245.8 & 74.7 & 115.6 & 320.5 & 17.9 & 64.5 & 206.0 & 27.2 & 966.0 & 208.7 & 12.0 & 109.4 \\
\hline 7247.6 & 51.0 & 102.7 & 175.3 & 18.5 & 27.8 & 50.8 & 22.9 & 856.3 & 182.1 & 9.0 & 124.7 \\
\hline 7249.9 & 102.9 & 113.2 & 474.9 & 18.5 & 55.6 & 317.8 & 25.7 & 903.1 & 200.9 & 12.9 & 111.7 \\
\hline 7252.2 & 83.8 & 109.6 & 255.7 & 20.0 & 60.9 & 57.0 & 24.3 & 867.7 & 193.3 & 11.8 & 124.0 \\
\hline 7255.8 & 75.1 & 108.4 & 299.4 & 19.2 & 75.2 & 202.4 & 27.7 & 1076.3 & 224.2 & 16.0 & 125.3 \\
\hline 7258.3 & 123.8 & 90.0 & 240.7 & 16.1 & 61.4 & 305.4 & 22.8 & 1300.5 & 172.3 & 11.9 & 139.2 \\
\hline 7261.9 & 52.4 & 95.2 & 154.3 & 18.7 & 49.2 & 48.7 & 25.9 & 981.4 & 201.6 & 12.4 & 135.8 \\
\hline 7264.6 & 80.9 & 95.7 & 168.5 & 18.7 & 57.7 & 53.7 & 24.6 & 971.1 & 201.3 & 9.2 & 131.7 \\
\hline 7267.8 & 78.8 & 98.1 & 217.6 & 18.4 & 54.2 & 49.6 & 26.8 & 1030.7 & 209.9 & 12.0 & 122.1 \\
\hline 7270.3 & 67.8 & 99.5 & 208.6 & 17.7 & 45.3 & 48.7 & 27.1 & 1056.4 & 213.6 & 12.6 & 123.7 \\
\hline 7272.7 & 86.2 & 96.5 & 209.8 & 17.9 & 57.7 & 110.6 & 24.5 & 988.0 & 200.9 & 11.2 & 117.9 \\
\hline 7275.9 & 57.8 & 96.3 & 190.1 & 18.6 & 41.0 & 90.7 & 26.2 & 1023.2 & 208.4 & 11.6 & 120.2 \\
\hline 7278.6 & 69.6 & 95.7 & 186.9 & 18.6 & 43.4 & 111.2 & 25.0 & 1001.8 & 203.6 & 15.4 & 124.3 \\
\hline 7281.7 & 66.4 & 83.9 & 177.1 & 23.6 & 47.2 & 130.4 & 22.8 & 928.6 & 184.6 & 13.6 & 140.1 \\
\hline 7284.7 & 66.1 & 93.8 & 177.6 & 18.2 & 42.5 & 74.1 & 26.5 & 1052.5 & 209.0 & 13.6 & 124.9 \\
\hline 7287.8 & 47.4 & 94.5 & 192.9 & 18.9 & 34.0 & 87.8 & 25.9 & 1042.5 & 209.5 & 13.2 & 122.8 \\
\hline 7290.5 & 65.6 & 92.9 & 195.1 & 18.4 & 44.8 & 80.2 & 25.1 & 998.2 & 197.1 & 12.7 & 121.5 \\
\hline 7296.9 & 65.3 & 94.2 & 197.6 & 18.2 & 42.2 & 57.5 & 25.7 & 1011.3 & 201.8 & 11.1 & 122.9 \\
\hline 7299.9 & 66.8 & 95.5 & 213.7 & 17.9 & 38.2 & 104.6 & 25.4 & 1006.6 & 205.6 & 13.1 & 114.4 \\
\hline 7303.0 & 71.7 & 97.3 & 231.4 & 18.1 & 63.9 & 1206.4 & 25.3 & 1026.5 & 203.0 & 15.8 & 121.2 \\
\hline 7305.8 & 82.5 & 93.2 & 202.6 & 18.7 & 65.6 & 249.9 & 25.1 & 1027.1 & 195.0 & 9.8 & 133.8 \\
\hline 7309.2 & 61.4 & 97.0 & 199.0 & 18.7 & 42.2 & 53.4 & 25.2 & 1022.9 & 203.5 & 13.5 & 125.7 \\
\hline 7311.9 & 51.6 & 95.1 & 189.5 & 18.3 & 39.5 & 71.0 & 25.6 & 969.8 & 195.9 & 13.6 & 118.2 \\
\hline 7314.7 & 69.5 & 101.4 & 203.9 & 17.9 & 50.2 & 84.3 & 26.1 & 1043.9 & 203.0 & 11.2 & 121.1 \\
\hline 7317.8 & 59.4 & 99.5 & 205.3 & 17.2 & 40.7 & 61.6 & 24.4 & 1037.0 & 202.0 & 12.3 & 124.4 \\
\hline 7320.7 & 70.5 & 104.9 & 215.4 & 18.3 & 35.4 & 51.9 & 24.6 & 1057.9 & 206.0 & 12.1 & 124.1 \\
\hline 7323.5 & 74.5 & 100.4 & 200.5 & 18.4 & 41.3 & 164.4 & 26.4 & 1025.8 & 204.1 & 12.5 & 120.5 \\
\hline 7326.7 & 53.6 & 102.4 & 180.9 & 18.5 & 45.8 & 51.5 & 26.7 & 1052.1 & 205.1 & 12.9 & 135.0 \\
\hline 7330.3 & 74.4 & 100.0 & 209.7 & 17.8 & 56.5 & 120.1 & 26.6 & 1069.3 & 209.0 & 13.8 & 136.9 \\
\hline 7333.1 & 38.1 & 102.7 & 175.8 & 17.7 & 28.4 & 46.2 & 26.9 & 1112.9 & 212.8 & 10.7 & 135.1 \\
\hline
\end{tabular}




\begin{tabular}{cccccccccccc}
\hline $\mathbf{7 3 3 6 . 5}$ & 57.5 & 91.0 & 137.1 & 18.0 & 67.4 & 45.1 & 21.0 & 1075.2 & 166.4 & 6.6 & 175.6 \\
$\mathbf{7 3 3 8 . 9}$ & 83.1 & 97.8 & 203.1 & 18.4 & 81.6 & 114.6 & 25.0 & 996.9 & 202.5 & 13.1 & 119.0 \\
$\mathbf{7 3 4 2 . 3}$ & 82.2 & 94.5 & 307.1 & 17.0 & 64.0 & 51.3 & 22.8 & 981.8 & 189.4 & 11.2 & 128.5 \\
$\mathbf{7 3 4 4 . 9}$ & 92.3 & 92.4 & 276.0 & 17.3 & 75.0 & 88.2 & 23.9 & 979.5 & 192.5 & 13.1 & 123.1 \\
$\mathbf{7 3 4 7 . 8}$ & 77.7 & 99.2 & 284.5 & 16.4 & 63.4 & 508.0 & 23.6 & 1078.4 & 199.4 & 12.3 & 118.8 \\
$\mathbf{7 3 5 1 . 0}$ & 85.4 & 100.5 & 292.7 & 17.2 & 77.8 & 45.1 & 24.3 & 1206.3 & 197.9 & 12.2 & 124.8 \\
$\mathbf{7 3 5 4 . 4}$ & 24.0 & 13.6 & 56.3 & 0.0 & 18.0 & 11.1 & 3.3 & 2385.9 & 17.8 & 0.1 & 304.5 \\
$\mathbf{7 3 5 7 . 3}$ & 101.3 & 97.1 & 349.2 & 16.6 & 92.5 & 50.1 & 24.1 & 1203.1 & 191.9 & 12.8 & 112.8 \\
$\mathbf{7 3 6 0 . 5}$ & 89.5 & 83.5 & 272.2 & 16.7 & 74.6 & 151.7 & 19.7 & 885.4 & 167.5 & 10.4 & 121.0 \\
$\mathbf{7 3 6 3 . 4}$ & 106.8 & 89.2 & 374.3 & 19.3 & 96.7 & 122.8 & 21.9 & 960.1 & 176.7 & 13.5 & 133.7 \\
$\mathbf{7 3 6 6 . 9}$ & 106.6 & 90.7 & 363.4 & 15.6 & 86.4 & 65.5 & 20.9 & 1011.6 & 184.2 & 10.9 & 126.7 \\
$\mathbf{7 3 6 9 . 9}$ & 121.8 & 91.0 & 404.0 & 16.5 & 84.0 & 3156.0 & 22.2 & 979.9 & 180.7 & 20.3 & 122.6 \\
$\mathbf{7 3 7 3 . 1}$ & 108.6 & 92.5 & 397.6 & 16.3 & 92.1 & 39.9 & 23.5 & 1033.4 & 192.3 & 12.6 & 113.3 \\
$\mathbf{7 3 7 7 . 2}$ & 107.5 & 90.1 & 352.6 & 16.1 & 92.2 & 35.3 & 22.6 & 953.5 & 177.1 & 12.7 & 113.4 \\
$\mathbf{7 3 8 1 . 1}$ & 94.7 & 96.4 & 311.2 & 20.8 & 119.3 & 37.3 & 23.0 & 987.9 & 184.1 & 10.5 & 158.6 \\
$\mathbf{7 3 8 3 . 2}$ & 99.4 & 94.2 & 303.9 & 16.9 & 85.8 & 34.7 & 23.7 & 1041.8 & 194.2 & 13.2 & 114.4 \\
$\mathbf{7 3 8 5 . 7}$ & 121.2 & 94.5 & 342.2 & 17.2 & 115.1 & 90.5 & 25.2 & 1070.5 & 193.3 & 12.4 & 115.8 \\
$\mathbf{7 3 8 8 . 1}$ & 113.3 & 79.1 & 157.6 & 17.5 & 114.5 & 1364.5 & 19.0 & 907.6 & 165.9 & 13.1 & 191.5 \\
$\mathbf{7 3 9 1 . 2}$ & 186.3 & 93.2 & 363.1 & 16.5 & 120.4 & 2432.4 & 22.2 & 1064.8 & 193.6 & 19.1 & 113.4 \\
$\mathbf{7 3 9 4 . 2}$ & 165.9 & 100.7 & 399.0 & 18.3 & 144.6 & 52.2 & 26.7 & 1192.2 & 218.7 & 14.5 & 119.1 \\
$\mathbf{7 3 9 7 . 8}$ & 153.1 & 89.1 & 295.0 & 21.1 & 154.9 & 46.5 & 23.5 & 1057.3 & 197.2 & 12.6 & 126.8 \\
\hline $\mathbf{M F \mathbf { A v g } .}$ & 85.0 & 98.0 & 261.9 & 17.7 & 65.7 & 252.5 & 24.0 & 1024.6 & 192.3 & 12.3 & 127.8 \\
\hline & & & & & & & & & & &
\end{tabular}

\begin{tabular}{cccccccccccc}
\hline Depth (ft) & $\mathbf{Y}$ & $\mathbf{Z r}$ & $\mathbf{H f}$ & $\mathbf{N b}$ & $\mathbf{M o}$ & $\mathbf{L a}$ & $\mathbf{C e}$ & $\mathbf{N d}$ & $\mathbf{S m}$ & $\mathbf{D y}$ & $\mathbf{Y b}$ \\
\hline $\mathbf{7 2 2 2 . 3}$ & 29.4 & 140.2 & 4.29 & 11.94 & 0.75 & 37.67 & 73.67 & 31.70 & 5.87 & 4.66 & 1.77 \\
$\mathbf{7 2 2 5 . 3}$ & 30.3 & 138.8 & 3.90 & 12.83 & 18.03 & 38.01 & 70.54 & 32.53 & 6.23 & 5.02 & 5.48 \\
$\mathbf{7 2 2 8 . 1}$ & 24.6 & 117.4 & 3.71 & 10.32 & 15.97 & 33.97 & 72.80 & 33.35 & 5.91 & 3.88 & 2.91 \\
$\mathbf{7 2 2 9 . 9}$ & 22.5 & 103.8 & 2.69 & 9.83 & 16.51 & 28.10 & 58.33 & 23.92 & 4.45 & 3.43 & 3.43 \\
$\mathbf{7 2 3 3 . 3}$ & 27.5 & 107.6 & 2.88 & 10.31 & 18.39 & 33.44 & 66.24 & 27.41 & 4.83 & 4.46 & 4.27 \\
$\mathbf{7 2 3 7 . 3}$ & 35.0 & 169.0 & 5.41 & 14.81 & 1.33 & 41.40 & 77.29 & 36.27 & 6.36 & 5.51 & 1.42 \\
$\mathbf{7 2 4 0 . 2}$ & 22.5 & 110.5 & 3.44 & 9.87 & 1.76 & 32.34 & 57.99 & 28.64 & 5.20 & 3.35 & 2.91 \\
$\mathbf{7 2 4 4 . 4}$ & 25.3 & 116.1 & 3.22 & 10.41 & 30.30 & 30.67 & 57.56 & 24.50 & 4.79 & 3.96 & 6.17 \\
$\mathbf{7 2 4 5 . 8}$ & 26.8 & 123.4 & 3.39 & 11.57 & 14.39 & 38.66 & 69.05 & 30.39 & 5.46 & 4.14 & 5.17 \\
$\mathbf{7 2 4 7 . 6}$ & 38.2 & 175.1 & 5.32 & 14.62 & 0.76 & 35.40 & 74.41 & 34.74 & 6.74 & 6.07 & 7.12 \\
$\mathbf{7 2 4 9 . 9}$ & 29.3 & 129.4 & 3.71 & 12.99 & 35.82 & 33.50 & 65.41 & 28.76 & 5.01 & 4.55 & 2.69 \\
$\mathbf{7 2 5 2 . 2}$ & 31.6 & 119.9 & 3.72 & 12.54 & 15.61 & 36.33 & 72.65 & 31.96 & 6.13 & 5.02 & 2.23 \\
$\mathbf{7 2 5 5 . 8}$ & 29.4 & 125.8 & 3.69 & 11.79 & 14.74 & 37.87 & 81.82 & 33.91 & 5.99 & 4.61 & 1.20 \\
$\mathbf{7 2 5 8 . 3}$ & 26.1 & 106.8 & 3.44 & 10.41 & 42.44 & 31.40 & 58.91 & 27.15 & 5.25 & 4.16 & 3.17 \\
$\mathbf{7 2 6 1 . 9}$ & 30.4 & 142.9 & 4.75 & 14.90 & 4.75 & 40.87 & 78.48 & 33.80 & 6.42 & 4.75 & 2.51 \\
$\mathbf{7 2 6 4 . 6}$ & 32.8 & 136.0 & 3.95 & 12.49 & 25.54 & 39.60 & 81.31 & 37.21 & 6.52 & 5.14 & 2.02 \\
$\mathbf{7 2 6 7 . 8}$ & 29.4 & 137.3 & 4.40 & 13.75 & 26.68 & 40.79 & 77.92 & 32.91 & 5.50 & 4.58 & 0.00 \\
$\mathbf{7 2 7 0 . 3}$ & 33.4 & 146.9 & 4.08 & 13.89 & 13.34 & 39.74 & 79.84 & 37.70 & 6.48 & 5.28 & 4.26 \\
\hline
\end{tabular}




\begin{tabular}{|c|c|c|c|c|c|c|c|c|c|c|c|}
\hline 7272.7 & 0.1 & 135.4 & 15 & 2.87 & 18.10 & 37.18 & 72.56 & 32.68 & 05 & .77 & \\
\hline 7275.9 & & & & & 10.45 & & 75.34 & & & & \\
\hline & & & & & & & & & & & \\
\hline 7281.7 & & 8.4 & 46 & & & & 3.30 & & & & .70 \\
\hline 284.7 & 2.6 & 9.6 & 53 & 41 & 8.75 & 4.62 & 4.63 & 8.06 & 47 & 7 & .12 \\
\hline 7287 & & & & & & & & & & & \\
\hline & & & & & & & & & & & \\
\hline 7296.9 & & & .73 & & 10.54 & & & & & & 4.29 \\
\hline 7299.9 & 1.0 & 42.3 & 4.91 & 14.45 & 23.71 & 41.58 & 7.24 & 34.73 & 48 & 4.91 & 3.70 \\
\hline 7303 & & & & & & & & & & & 4.69 \\
\hline 7305.8 & & & 80 & & 15.67 & & & & & & 6.57 \\
\hline & & & & & & & & & & & 363 \\
\hline 7311.9 & 32 & 35.8 & 3.98 & 4 & 52 & 37.65 & 3.28 & & & 2 & 2.37 \\
\hline 7314.7 & & 147 & 4.45 & & & & & & & & 2.78 \\
\hline & & & 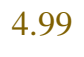 & & & & & & & 3.2 & 2.68 \\
\hline & & & & & & & & & & & \\
\hline & & & & & & & & & & & 4.06 \\
\hline 7326.7 & & 1.4 & 4.17 & & & & & & & & 1.52 \\
\hline & & & 0 & & & & & & & & 3.59 \\
\hline & & & & & & & & & & & \\
\hline & & & & & & & & & & & \\
\hline 7338. & & & 3.80 & & & & & & & & 4.36 \\
\hline & & & & & & & & & & & 3.02 \\
\hline & & & 9 & & & & & & & & \\
\hline & & & & & & & & & & & \\
\hline & & & & & & & & & & & \\
\hline & & & 76 & & & & & & & & 3.52 \\
\hline 7357.3 & & 1.4 & 98 & 10. & 40. & & & & & 4 & 52 \\
\hline & & & & & & & & & & & \\
\hline & & & & & & & & & & & \\
\hline & & & 3.02 & & & & & & & & \\
\hline 7369.9 & & 108.4 & 3.09 & 10. & 69.06 & & 59.15 & & .72 & 5.00 & 2.54 \\
\hline & & & & & & & & & & & \\
\hline & & & & & & & & & & & 4.10 \\
\hline & & & & & & & & & & & 4.03 \\
\hline 7383.2 & & 118.0 & 3.55 & 11.8 & 27.56 & 36.20 & 69.22 & & 6.37 & 4.46 & 4.64 \\
\hline & & & & & & & & & & & 3.20 \\
\hline & & & & & & & & & & 7.13 & 4.24 \\
\hline & 32.9 & & & & & & & & 6.27 & 5.13 & 4.09 \\
\hline & 36.4 & & 3.76 & & & & & & 6.58 & 5.72 & 3.67 \\
\hline 7397.8 & 44.2 & 100.5 & 3.58 & 10.05 & 61.34 & 40.63 & 77.07 & 41.68 & 8.13 & 6.90 & 2.97 \\
\hline & & & & & & & & & & & \\
\hline
\end{tabular}




\begin{tabular}{|c|c|c|c|c|}
\hline Depth (ft) & $\overline{\mathbf{U}}$ & Tl & $\mathbf{P b}>=$ & $\mathbf{B i}$ \\
\hline 7222.30 & 5.87 & 2.98 & 5.69 & 2.05 \\
\hline 7225.30 & 4.46 & 1.30 & 20.82 & 0.00 \\
\hline 7228.10 & 10.41 & 0.62 & 11.65 & 0.71 \\
\hline 7229.90 & 5.19 & 3.06 & 42.75 & 1.21 \\
\hline 7233.30 & 3.16 & 2.69 & 24.34 & 0.65 \\
\hline 7237.30 & 3.42 & 1.90 & 17.09 & 0.57 \\
\hline 7240.20 & 3.44 & 2.20 & 29.61 & 0.97 \\
\hline 7244.40 & 8.29 & 3.22 & 22.75 & 0.92 \\
\hline 7245.80 & 7.90 & 3.67 & 24.74 & 1.51 \\
\hline 7247.60 & 3.23 & 1.80 & 16.14 & 0.47 \\
\hline 7249.90 & 10.39 & 1.21 & 18.46 & 0.00 \\
\hline 7252.20 & 4.65 & 1.58 & 31.40 & 0.00 \\
\hline 7255.80 & 8.57 & 1.01 & 31.97 & 0.00 \\
\hline 7258.30 & 4.80 & 3.89 & 35.02 & 1.18 \\
\hline 7261.90 & 2.14 & 3.07 & 29.61 & 1.21 \\
\hline 7264.60 & 4.59 & 2.02 & 38.95 & 0.00 \\
\hline 7267.80 & 3.85 & 2.66 & 35.02 & 0.83 \\
\hline 7270.30 & 5.28 & 3.52 & 33.16 & 0.56 \\
\hline 7272.70 & 5.49 & 3.87 & 37.18 & 1.62 \\
\hline 7275.90 & 3.51 & 3.70 & 26.35 & 0.65 \\
\hline 7278.60 & 6.09 & 4.36 & 23.54 & 1.91 \\
\hline 7281.70 & 6.07 & 1.87 & 27.73 & 0.65 \\
\hline 7284.70 & 3.33 & 1.94 & 29.56 & 0.37 \\
\hline 7287.80 & 3.19 & 2.54 & 21.78 & 1.78 \\
\hline 7290.50 & 1.92 & 2.84 & 30.50 & 0.64 \\
\hline 7296.90 & 5.22 & 1.49 & 43.19 & 0.37 \\
\hline 7299.90 & 4.26 & 1.67 & 23.25 & 0.19 \\
\hline 7303.00 & 4.32 & 1.60 & 24.49 & 0.47 \\
\hline 7305.80 & 3.75 & 0.84 & 32.64 & 0.00 \\
\hline 7309.20 & 3.16 & 4.93 & 32.57 & 2.14 \\
\hline 7311.90 & 3.60 & 2.66 & 18.12 & 0.57 \\
\hline 7314.70 & 3.89 & 4.08 & 25.85 & 1.67 \\
\hline 7317.80 & 3.51 & 3.51 & 19.23 & 1.76 \\
\hline 7320.70 & 4.57 & 2.98 & 19.77 & 0.19 \\
\hline 7323.50 & 2.22 & 3.42 & 23.00 & 1.02 \\
\hline 7326.70 & 4.46 & 1.23 & 19.26 & 0.76 \\
\hline 7330.30 & 3.69 & 0.85 & 23.06 & 0.09 \\
\hline 7333.10 & 2.37 & 2.85 & 15.09 & 1.90 \\
\hline 7336.50 & 3.59 & 0.00 & 30.71 & 0.00 \\
\hline 7338.90 & 6.30 & 1.30 & 34.66 & 0.37 \\
\hline 7342.30 & 5.60 & 3.38 & 27.93 & 0.09 \\
\hline 7344.90 & 6.25 & 4.60 & 24.73 & 0.64 \\
\hline
\end{tabular}




\begin{tabular}{ccccc}
\hline $\mathbf{7 3 4 7 . 8 0}$ & 7.14 & 1.46 & 24.79 & 0.46 \\
$\mathbf{7 3 5 1 . 0 0}$ & 4.54 & 1.85 & 28.33 & 0.00 \\
$\mathbf{7 3 5 4 . 4 0}$ & 2.37 & 0.00 & 4.06 & 0.00 \\
$\mathbf{7 3 5 7 . 3 0}$ & 6.24 & 3.62 & 28.22 & 0.00 \\
$\mathbf{7 3 6 0 . 5 0}$ & 6.15 & 2.39 & 26.81 & 0.18 \\
$\mathbf{7 3 6 3 . 4 0}$ & 9.31 & 2.26 & 22.33 & 0.00 \\
$\mathbf{7 3 6 6 . 9 0}$ & 8.61 & 4.49 & 25.10 & 0.92 \\
$\mathbf{7 3 6 9 . 9 0}$ & 10.36 & 3.54 & 21.17 & 0.09 \\
$\mathbf{7 3 7 3 . 1 0}$ & 8.17 & 3.36 & 25.95 & 0.45 \\
$\mathbf{7 3 7 7 . 2 0}$ & 5.93 & 5.02 & 29.37 & 1.19 \\
$\mathbf{7 3 8 1 . 1 0}$ & 11.26 & 2.93 & 25.09 & 0.00 \\
$\mathbf{7 3 8 3 . 2 0}$ & 7.64 & 2.09 & 28.92 & 0.00 \\
$\mathbf{7 3 8 5 . 7 0}$ & 8.36 & 4.71 & 31.64 & 0.00 \\
$\mathbf{7 3 8 8 . 1 0}$ & 9.30 & 4.24 & 30.33 & 2.08 \\
$\mathbf{7 3 9 1 . 2 0}$ & 12.97 & 7.83 & 32.46 & 0.87 \\
$\mathbf{7 3 9 4 . 2 0}$ & 15.89 & 6.92 & 33.58 & 0.17 \\
$\mathbf{7 3 9 7 . 8 0}$ & 15.90 & 1.57 & 33.90 & 0.00 \\
\hline \hline MF Avg. & 5.9 & 2.8 & 26.4 & 0.7 \\
\hline
\end{tabular}


APPENDIX XIV. Radiogenic Samarium-Neodymium isotopic data.

\begin{tabular}{ccccccccc}
\hline Well & Depth (ft) & Unit & Sm (ppm) & Nd (ppm) & $\begin{array}{c}{ }^{\mathbf{1 4 7}} \mathbf{S m} / \\
{ }^{\mathbf{1 4 4}} \mathbf{N d}\end{array}$ & $\begin{array}{c}{ }^{\mathbf{1 4 3}} \mathbf{N d} / \\
\text { Nd }\end{array}$ & $\mathbf{\varepsilon N d}$ & $\boldsymbol{\tau}_{\mathbf{N d}}$ \\
\hline WV-6 & 7225.3 & MF & 5.99 & 32.5 & 0.1112 & 0.512041 & -11.65 & 1.65 \\
WV-6 & 7270.3 & MF & 7.27 & 38.6 & 0.1138 & 0.51205 & -11.47 & 1.67 \\
WV-6 & 7314.7 & MF & 7.03 & 38.5 & 0.1104 & 0.512036 & -11.74 & 1.64 \\
WV-6 & 7360.5 & MF & 6.96 & 34.3 & 0.1227 & 0.512106 & -10.38 & 1.74 \\
MIP-3H & 7448.35 & MF & 4.27 & 20.13 & 0.1281 & 0.512108 & -10.34 & 1.85 \\
MIP-3H & 7460.2 & MS & 6.85 & 33.25 & 0.1245 & 0.512099 & -10.51 & 1.79 \\
MIP-3H & 7489.06 & MS & 6.9 & 36.2 & 0.1152 & 0.512097 & -10.55 & 1.63 \\
MIP-3H & 7505.93 & MS & 5.57 & 26.53 & 0.1269 & 0.512116 & -10.18 & 1.81 \\
MIP-3H & 7538.15 & MS & 6.65 & 31.7 & 0.1269 & 0.512133 & -9.85 & 1.78 \\
MIP-3H & 7544.85 & MS & 5.19 & 16.6 & 0.1891 & 0.512276 & -7.06 & 5.34 \\
\hline
\end{tabular}

